\title{
Forest Preservation in a Changing Climate
}

REDD+ and Indigenous and Community Rights in Indonesia and Tanzania

\section{Sébastien Jodoin}

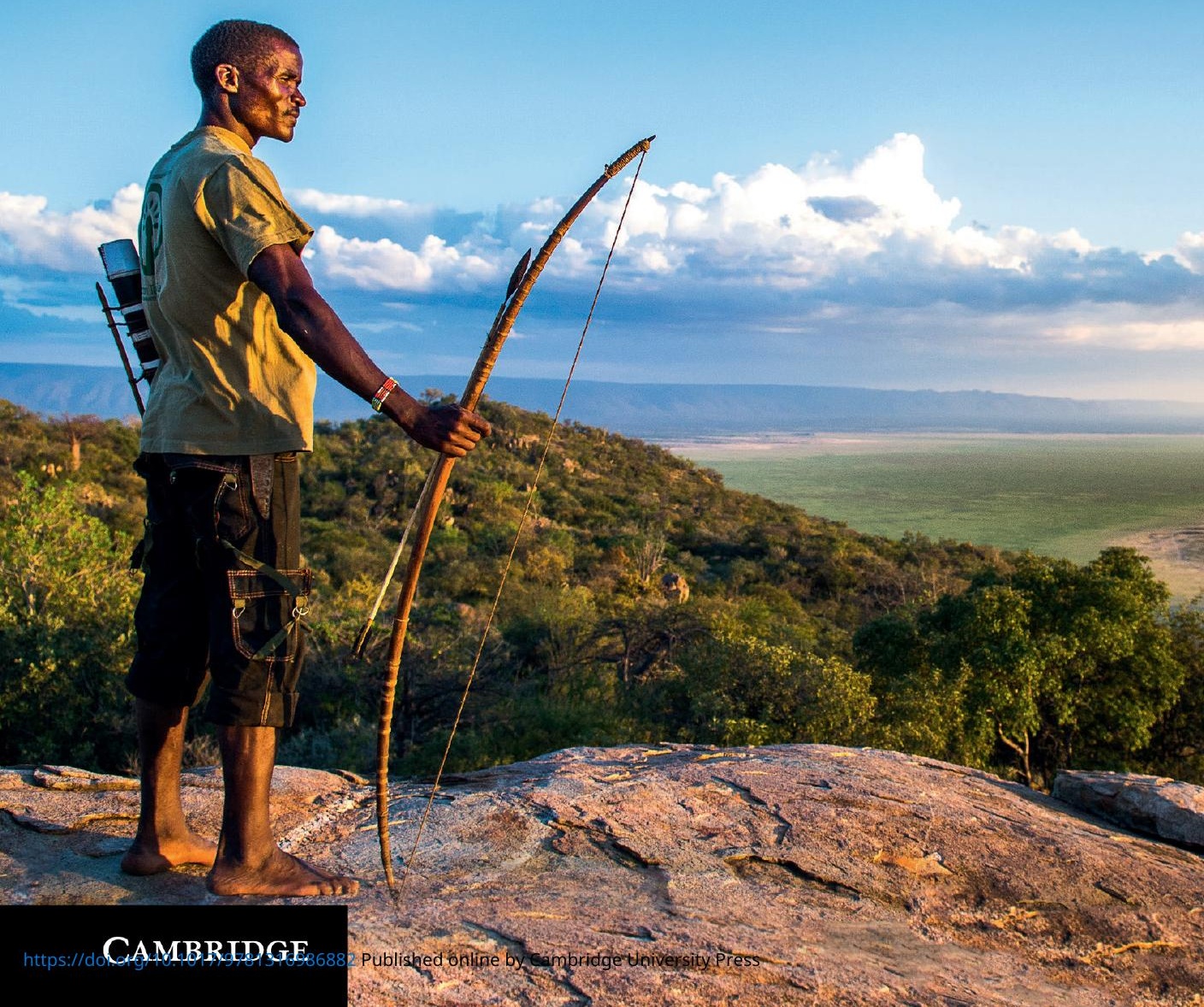




\section{FOREST PRESERVATION IN A CHANGING CLIMATE}

This book provides a comprehensive socio-legal examination of how global efforts to fight climate change by reducing carbon emissions in the forestry sector (known as REDD+) have affected the rights of Indigenous Peoples and local communities in developing countries. Grounded in extensive qualitative empirical research conducted globally, the book shows that the transnational legal process for REDD+ has created both serious challenges and unexpected opportunities for the recognition and protection of indigenous and community rights. It reveals that the pursuit of REDD+ has resulted in important variations in how human rights standards are understood and applied across multiple sites of law in the field of REDD+, with mixed results for Indigenous Peoples and local communities in Indonesia and Tanzania. With its original findings, rigourous research design, and interdisciplinary analytical framework, this book will make a valuable contribution to the study of transnational legal processes in a globalizing world. This title is also available as Open Access on Cambridge Core at http://dx.doi.org/10.1017/9781316986882.

Sébastien Jodoin is an Assistant Professor in the Faculty of Law at McGill University, Montréal, and is a member of the McGill Centre for Human Rights and Legal Pluralism. He previously worked for Amnesty International Canada, the United Nations, the Centre for International Sustainable Development Law, and the Canadian Centre for International Justice. 


\title{
Forest Preservation in a Changing Climate
}

\author{
REDD + AND INDIGENOUS AND COMMUNITY \\ RIGHTS IN INDONESIA AND TANZANIA
}

\section{SÉBASTIEN JODOIN}

McGill University, Montréal 


\section{CAMBRIDGE \\ UNIVERSITY PRESS}

University Printing House, Cambridge св2 8вs, United Kingdom

One Liberty Plaza, 2oth Floor, New York, NY 10006, USA

477 Williamstown Road, Port Melbourne, vIC 3207, Australia

4843/24, 2nd Floor, Ansari Road, Daryaganj, Delhi - 110002, India

79 Anson Road, \#o6-o4/o6, Singapore 079906

Cambridge University Press is part of the University of Cambridge.

It furthers the University's mission by disseminating knowledge in the pursuit of education, learning, and research at the highest international levels of excellence.

www.cambridge.org

Information on this title: www.cambridge.org/9781107189003

DOI: $10.1017 / 9781316986882$

(C) Sébastien Jodoin 2017

This work is in copyright. It is subject to statutory exceptions and to the provisions of relevant licensing agreements; with the exception of the Creative Commons version the link for which is provided below, no reproduction of any part of this work may take place without the written permission of Cambridge University Press.

An online version of this work is published at http://dx.doi.org/10.1017/9781316986882. under a Creative Commons Open Access license CC-BY-NC-ND 4.0 which permits re-use, distribution and reproduction in any medium for non-commercial purposes providing appropriate credit to the original work is given. You may not distribute derivative works without permission.

To view a copy of this license, visit https://creativecommons.org/licenses/by-nc-nd/4.o.

All versions of this work may contain content reproduced under license from third parties. Permission to reproduce this third-party content must be obtained from these third-parties directly.

When citing this work, please include a reference to the DOI 10.1017/9781316986882.

First published 2017

Printed in the United States of America by Sheridan Books, Inc.

A catalogue record for this publication is available from the British Library.

Library of Congress Cataloging-in-Publication Data

NAMES: Jodoin, Sébastien, 1982- author.

TITLE: Forest preservation in a changing climate : REDD+ and indigenous and community rights in Indonesia and Tanzania / Sébastien Jodoin, McGill University, Montreal. Description: Cambridge, United Kingdom ; New York, NY : Cambridge University Press, 2017. | Includes bibliographical references and index. IDENTIFIERS: LCCN 2017028167 | ISBN 9781107189003 (hardback) SubJECTS: LCSH: Reducing Emissions from Deforestation and Forest Degradation (Program) | Deforestation - Control - Indonesia. | Forest degradation - Control Indonesia. | Deforestation - Control - Tanzania. | Forest degradation - Control Tanzania. | Climatic changes. | Indigenous peoples - Ecology.

CLASSIFICATION: LCC SD418.3.I5 J63 2017 | DDC 333.7509598-dc23

LC record available at https://ccn.loc.gov/2017028167

ISBN 978-1-107-18900-3 Hardback

Cambridge University Press has no responsibility for the persistence or accuracy of URLs for external or third-party internet websites referred to in this publication and does not guarantee that any content on such websites is, or will remain, accurate or appropriate. 


\section{Contents}

Acknowledgments

page viii

Disclosures

List of Abbreviations and Acronyms

Introduction: Grappling with the REDD+ Paradox 1

Background and Context

Existing Knowledge

Analytical Framework

Research Design

Originality and Significance

Overview

1 The Transnational Legal Process for REDD+

1.1 The Origins of the Transnational Legal Process for REDD+

1.2 Levels, Sites, and Forms of Law in the Transnational Legal Process for REDD+

1.3 The Complexity of the Transnational Legal Process for REDD+

2 Rights and REDD+ in International and Transnational Law

2.1 The Emergence of Rights in the Field of REDD+

2.2 Indigenous and Community Rights in UNFCCC Decision-Making on REDD+

2.3 Indigenous and Community Rights in the World Bank FCPF

2.4 Indigenous and Community Rights in the UN-REDD Programme 
2.5 Indigenous and Community Rights in the CCBA 74

2.6 Indigenous and Community Rights in the REDD+ SES 79

2.7 Heterogeneity in the Recognition of Indigenous and Community Rights in International and Transnational Sites of Law for REDD+

3 Rights and Jurisdictional REDD+ in Indonesia 87

3.1 Forests, Governance, and Rights in Indonesia 87

3.2 The Pursuit and Governance of Jurisdictional REDD+ in Indonesia

3.3 The Rights of Indigenous Peoples and Local Communities in Jurisdictional REDD+ Readiness Activities in Indonesia 94

3.4 Explaining the Conveyance and Construction of Rights through Jurisdictional REDD+ Activities in Indonesia

3.5 REDD+ and the Future of Indigenous and Community Rights in Indonesia 114

4 Rights and Jurisdictional REDD+ in Tanzania 117

4.1 Forests, Governance, and Rights in Tanzania 117

4.2 The Pursuit and Governance of Jurisdictional REDD+ in Tanzania

4.3 The Rights of Indigenous Peoples and Local Communities in Jurisdictional REDD+ Readiness Activities in Tanzania 129

4.4 Explaining the Conveyance and Construction of Rights through Jurisdictional REDD+ Activities in Tanzania

4.5 REDD + and the Future of Indigenous and Community Rights in Tanzania 148

5 Rights and Project-Based REDD+ in Indonesia and Tanzania 151

5.1 The Transnational Market for Project-Based REDD+ Activities 151

5.2 Rights and Project-Based REDD+ Activities in Indonesia 153

5.3 Rights and Project-Based REDD+ Activities in Tanzania 159

5.4 Explaining the Conveyance and Construction of Rights in Project-Based REDD+ Activities in Indonesia and Tanzania 165

5.5 The Future of Indigenous and Community Rights in the Transnational Market for REDD+ $\quad 170$

6 Comparing Rights and REDD+ in Indonesia and Tanzania 177

6.1 Rights and Jurisdictional REDD+ in Indonesia and Tanzania 
6.2 Rights and Project-Based REDD+ in Indonesia and Tanzania

6.3 Rights and REDD+ at Multiple Levels in Indonesia and Tanzania

Conclusion: REDD+, Rights, and Law in a Transnational Perspective

Significant Findings on REDD+ and Rights

Limitations

Future Research on REDD+ and Rights

Implications for the Study of Transnational Legal Processes

REDD+ and the Intersections of Human Rights

and Environmental Governance

208

Annex I: Overview of REDD+ Activities in the Developing World 


\section{Acknowledgments}

The origins of this book lie in my previous professional work as a lawyer in the fields of human rights and climate change. As a delegate of the Centre for International Sustainable Development Law to the 11th, 12th, and 13th sessions of the UNFCCC COP held in Montreal in 2005, Nairobi in 2006, and Bali in 2007, I had the opportunity to witness the emergence of REDD+ in the international climate negotiations as well as the enthusiasm and controversy that it generated among the delegates in attendance. Next, at the 15th session of the UNFCCC COP held in Copenhagen in 2009, I served on the first (and last) delegation sent by Amnesty International to the international climate negotiations. During the negotiations, I participated in the first meeting of what would later become the Human Rights \& Climate Change Working Group, an informal network of lawyers and activists working to integrate human rights standards and principles into international climate law. I also had the opportunity to discuss the role and relevance of human rights to the governance of REDD+ with a number of civil society and government delegates throughout the negotiations. This experience, along with fortuitous encounters with a number of graduate students from the Yale School of Forestry \& Environmental Studies attending the climate negotiations in Copenhagen, led me to apply to pursue a PhD in environmental studies at Yale University. In fact, I prepared and submitted my application to Yale while sitting on the floor of the overcrowded Bella Centre in anticipation of the start of a negotiating session that would never take place due to the collapse of the talks in Copenhagen.

From 2010 to 2015, I had the opportunity to complete a $\mathrm{PhD}$ in environmental studies at Yale, which proved to be a more intellectually enriching and academically ambitious journey than I could ever have envisioned. The support of numerous individuals and organizations was critical to my progress along the way. At Yale, I benefited immensely from the encouragement, 
creativity, and enthusiasm of my supervisor, Benjamin Cashore. I learned so many different things from Ben during my doctoral studies and I hope to inspire, support, and mentor my own doctoral students in a similar manner. I also benefited from the expertise, wisdom, and encouragement of the other members of my doctoral committee, Daniel Esty, Alec Stone Sweet, and Jaye Ellis, who have each contributed in very different ways to my doctoral research and to my development as a legal scholar. Thanks are due to my former colleagues at the Yale School of Forestry \& Environmental Studies and in the community of Trudeau Scholars, with whom I had stimulating exchanges about important academic questions as well as sharing the small victories and defeats that come with the daily grind of completing a doctorate.

I also want to thank the ninety-four individuals who agreed to discuss their work with me as well as the many other individuals across dozens of organizations who provided me with access to sites, meetings, and documents relating to REDD+. Although I do not necessarily agree with their views or positions on all matters relating to REDD+, I am inspired by their determination to find solutions to complex problems at the intersections of forest governance, climate change, human rights, and sustainable development.

There is absolutely no way I could have completed this research without the financial support that the Yale Graduate School of Arts and Sciences, the Pierre Elliott Trudeau Foundation, the Social Sciences and Humanities Research Council of Canada, and the Climate and Land Use Alliance provided for my doctoral research. I must especially single out Josée St-Martin at the Trudeau Foundation and Elisabeth Barsa at Yale for supporting me every step of the way, in the face of the financial, personal, and administrative challenges that typically materialize in the course of completing a doctorate. In addition, I am very grateful to Catherine Potvin, who was kind enough to host me as a visiting doctoral student in the Neotropical Ecology Lab that she directs at McGill University. More recently, I have benefited from Catherine's mentorship and support as a junior colleague and have participated in some of the many important projects and initiatives that she leads in the fields of REDD+ and climate change.

While completing the research that is at the heart of this book, I had the honour of joining McGill University's Faculty of Law as an assistant professor. I have benefited from the advice and support of numerous colleagues in the early stages of my career, especially Mark Antaki, Adelle Blackett, Angela Campbell, Jaye Ellis, Richard Gold, Tena Groot, Alana Klein, Hoi Kong, Richard Janda, Robert Leckey, Marie Manikis, Fred Mégret, René Provost, Ron Niezen, Nandini Ramanujam, and Shauna Van Praagh. I have also had the opportunity to work with numerous talented undergraduate and graduate 
students at McGill. I especially want to thank Rosine Faucher, Kathryn Hansen, Katherine Lofts, Anna McIntosh, and Audrey Mocle for the invaluable research and editing assistance they provided for this book. I should mention that an insight development grant from the Social Sciences and Humanities Research Council of Canada has been instrumental in enabling me to complete this book and carry out related research on the linkages between human rights and climate change.

I also owe a debt of gratitude to John Berger and the dedicated staff of Cambridge University Press. John supported this project from the outset and guided the book from the peer review stage to its publication. The feedback received from two anonymous peer reviewers was also useful in finalizing this book. I am also grateful to the many scholars who offered comments on different drafts of this work that I presented at conferences and workshops over several years. I want to single out a scholar that I greatly admire, Lisa Vanhala, whose feedback was very useful in the final stages of preparing this book.

I want to thank Carbon Tanzania for giving me permission to use the photograph taken from its Yaeda Valley Project that appears on the cover of this book. Carbon Tanzania is a social enterprise that works with Indigenous communities in Tanzania to support the protection of their forests through engagement with the voluntary carbon market. Given the high level of social and environmental performance that it has achieved in its project and its community-based approach, I have committed to purchasing carbon credits sold by Carbon Tanzania to off-set the carbon emissions resulting from any travel that I may undertake to promote this book.

Finally, I want to acknowledge the critical role that the love and encouragement of my friends and family has played throughout the process of writing this book. It is a real privilege to go through life knowing that so many people are rooting for your success and are ready to help whenever they can, in ways big and small. Merci à maman, papa, Martin, Geneviève, Marie-Danielle, Charles-William, Anne-Élizabeth, Suzanne, Stéphane, Alfredo et Charles. Most of all, I owe an unending debt of gratitude to my wife, Sarah, and my daughter, Camille. Every day, they inspire me to be a better scholar, citizen, and person.

While I have been really blessed to benefit from the support of many individuals throughout the preparation of this book, I must emphasize the important contributions of a mentor who passed away in June 2014: Rod Macdonald. As a law student at McGill in the first half of the 2000s, I had the privilege of studying administrative process and legal education with Rod. Over the succeeding decade, he strongly and consistently encouraged me to 
pursue an academic career. He also introduced me to the idea that law is a plural phenomenon that is not reducible to the formal institutions of the state - an idea that underlies my approach in this book. In view of his influence on my career and thinking, I would like to dedicate this book to his memory and propose the following alternate title: "Or How I Learned to Study the Lessons of Everyday Transnational Law." 


\section{Disclosures}

I wish to voluntarily disclose that I have received remuneration and funding from two organizations that have supported the implementation and development of REDD+ around the world. First, I authored a case study and strategic working paper on the implications of REDD+ for the promotion of community forestry in Indonesia and Tanzania for the Climate and Land Use Alliance (CLUA). Second, I co-authored an academic sourcebook on REDD+ for the United Nations Environment Programme (UNEP). Third, I received funding from the UNEP to participate in a workshop held in May 2014 in Jakarta to design a new REDD+ Academy.

In addition, given the subject matter of this book, I also wish to disclose the estimated amount of carbon emissions that were produced through the extensive travel that I undertook to visit various sites and carry out interviews from 2011 to 2014. I performed this calculation using Yale University's Community Carbon Fund Calculator and took into account all travel (by air, road, and rail) that was undertaken primarily for the purposes of collecting data for this book. The total amount is as follows: 48,290 metric tons of carbon emissions. This is equivalent to the carbon sequestered in 373 acres of forests preserved from conversion to agricultural development in one year.

I am convinced that these engagements and this extensive travel were critical to my ability to complete this research and to contribute to existing knowledge on REDD+, rights, and transnational law. In the future, I will buy carbon credits from Carbon Tanzania to off-set any carbon emissions generated by any travel that I may undertake to promote this book. 


\section{Abbreviations and Acronyms}

ACHPR

AFOLU

AMAN

AUSAID

AWF

BAPPENAS

CBFM

CCBA

CCB Standards

CDM

CER

CI

CIFOR

CRN

CSO

DFID

ESMF

EU

FAO

FCPF

FFI

FPIC

FPP

GHG

GIZ
African Commission on Human and Peoples' Rights Agriculture, forestry, and land-use

Aliansi Masyarakat Adat Nusantara (Indigenous

Peoples Alliance of the Archipelago)

Australian Agency for International Development

African Wildlife Foundation

National Development Planning Agency

Community-Based Forest Management

Climate, Community \& Biodiversity Alliance

Climate, Community and Biodiversity Standards

Clean Development Mechanism

Certified Emissions Reduction

Conservation International

Centre for International Forestry Research

Coalition of Rainforest Nations

Civil Society Organization

UK Department for International Development

Environmental and Social Management Framework

European Union

Food and Agriculture Organization

Forest Carbon Partnership Facility

Fauna \& Flora International

Free, Prior, and Informed Consent

Forest Peoples Programme

Greenhouse gas

Deutsche Gesellschaft für Internationale

Zusammenarbeit (German Development Agency) 
GTZ

HuMa

IADB

ICRAF

IPO

IUCN

JFM

JNR

$\mathrm{KP}$

LULUCF

MRV

NGO

NICFI

NORAD

OHCHR

PES

PFM

PINGOs Forum

PRISAI

RED

REDD

REDD+

REDD SES

REL

R-PP

SESA

SIS

TFCG

TNC
Deutsche Gesellschaft für Technische Zusammenarbeit (German Development Agency) Association for Community and Ecology-Based Law Reform

Inter-American Development Bank

World Agroforestry Centre

Indigenous Peoples Organization

International Union for the Conservation of Nature

Joint Forest Management

Jurisdictional and Nested REDD+

Kyoto Protocol

Land use, land-use change, and forestry

Measurement, reporting, and verification

Non-Governmental Organization

Norwegian International Climate and Forests Initiative

Norwegian Agency for Development Cooperation

Office of the United Nations High Commissioner for Human Rights

Payment for ecosystem services

Participatory Forest Management

Pastoralists Indigenous Non-Governmental

Organizations Forum

Principles, Criteria, and Indicators for REDD+ Safeguards in Indonesia

Reducing emissions from deforestation

Reducing emissions from deforestation and forest degradation

Reducing emissions from deforestation and forest degradation in developing countries; and the role of conservation, sustainable management of forests, and enhancement of forest carbon stocks in developing countries

REDD social and environmental safeguards

Reference emissions level

Readiness Preparation Proposal

Strategic environmental and social assessment

Safeguards information system

Tanzania Forest Conservation Group

The Nature Conservancy 
$\mathrm{UKP}_{4}$

UNDP

UNDRIP

UNEP

UNFCCC

UNFCCC COP

UN-REDD

Programme

VCS

WCS

WCST

WRI

WWF
Indonesia’s President's Special Delivery Unit

United Nations Development Programme

United Nations Declaration on the Rights of Indigenous Peoples

United Nations Environment Programme

United Nations Framework Convention on Climate Change

Conference of the Parties to the United Nations Framework Convention on Climate Change

Subsidiary Body for Scientific and Technological Advice of the United Nations Framework Convention on Climate Change

Collaborative Programme of the United Nations on REDD

Verified Carbon Standard

Wildlife Conservation Society

Wildlife Conservation Society of Tanzania

World Resources Institute

World Wide Fund for Nature 


\section{Introduction \\ Grappling with the REDD+ Paradox}

\section{BACKGROUND AND CONTEXT}

"No rights, no REDD+." This was the key message of the Indigenous Peoples caucus as it walked out of the Poznan climate conference in December 2008 to protest the exclusion of rights language in a draft negotiating text on REDD+. ${ }^{1}$ This was not the first nor the last time that the new and ambitious global mechanism for reducing carbon emissions from deforestation and forest degradation, supporting the conservation and sustainable management of forests, and enhancing forest carbon stocks in developing countries (REDD+) negotiated within the United Nations Framework Conference for Climate Change ${ }^{2}$ (UNFCCC) would generate such controversy.

The basic idea behind REDD+ is that channeling climate finance from North to South to avoid deforestation and support carbon sequestration in developing country forests can not only contribute to the world's global climate mitigation efforts but can also protect forests and their critical ecosystems and help alleviate poverty among forest-dependent and rural communities. ${ }^{3}$ Because it has been seen as a relatively inexpensive, simple, and rapid way of reducing an estimated 17 percent of global carbon emissions worldwide, ${ }^{4}$ the development of REDD+ has moved forward with remarkable vigor within

1 Christopher Lang, “No rights, no REDD': Indigenous Peoples protest in Poznan” REDDMonitor, 9 December 2008, available at: www.redd-monitor.org/2008/12/og/no-rights-no-reddindigenous-peoples-protest-in-poznan/ (accessed 1 August 2014).

2 United Nations Framework Convention on Climate Change, 9 May 1992, 1771 U.N.T.S. 107, entered into force 21 March 1994, art. 4(1)(d).

3 Marleen Buizer, David Humphreys \& Wil de Jong, "Climate change and deforestation: The evolution of an intersecting policy domain" (2013) 35 Environmental Science E Policy 1.

4 Arild Angelsen \& Desmond McNeill, "The evolution of REDD+" in Arild Angelsen et al., eds., Analysing REDD+: Challenges and Choices (Bogor Barat, Indonesia: CIFOR, 2012) 31 at 35 . H-Holger Rogner et al., "Introduction" in Bert Metz et al., eds., Climate Change: The IPCC Scientific Assessment. Report of Working Group III to the Intergovernmental Panel on Climate 
the UNFCCC and beyond. ${ }^{5}$ Governments, international organizations, multilateral development banks, conservation and development NGOs, and corporations have established funding, knowledge-sharing, technical assistance, and certification programs to support the pursuit of REDD+ in developing countries. ${ }^{6}$ Across Africa, Asia, Latin America, and the Caribbean, over sixty governments have initiated multi-year programs of research, capacity-building, and reform to prepare for the implementation of REDD+ and have begun taking national action to reduce carbon emissions originating in their forests and manage international funds received for this purpose (known as jurisdictional REDD+). ${ }^{7}$ In addition, up to 350 projects have been initiated by governments, international organizations, NGOs, corporations, and communities in an effort to reduce carbon emissions from forest-based sources at the local level in over fifty developing countries (known as project-based REDD +$)^{8}$

Having emerged as a "triple-win" solution for forests, climate change, and development, REDD+ has become increasingly entangled with complex debates over the governance of forests, land, and resources in developing countries. ${ }^{9}$ It has most notably attracted significant attention and scrutiny from activists, scholars, and policy-makers due to its controversial implications for the rights of Indigenous Peoples and local communities ${ }^{10}$ in developing countries. ${ }^{11}$ On the one hand, REDD+ may provide new funds and momentum for the recognition and protection of the traditional lands of Indigenous

Change: Mitigation of Climate Change, available at: www.ipcc.ch/pdf/assessment-report/ar4/ wg3/ar4-wg3-chapter1.pdf (2007) at 105-106.

5 Constance L. McDermott, Kelly Levin \& Benjamin Cashore, "Building the Forest-Climate Bandwagon: REDD+ and the Logic of Problem Amelioration" (2011) 11:3 Global Environmental Politics 85.

6 Gillian A. Cerbu, Brent M. Swallow \& Dara Y. Thompson, "Locating REDD: A global survey and analysis of REDD readiness and demonstration activities" (2011) 14(2) Environmental Science \& Policy 168.

7 Annex I. Overview of REDD+ activities in the developing world. ${ }^{8}$ Ibid.

9 Chukwumerije Okereke \& Kate Dooley, "Principles of justice in proposals and policy approaches to avoided deforestation: Towards a post-Kyoto climate agreement" (2010) 20:1 Global Environmental Change 82.

10 I use the term "local communities" interchangeably with the term "forest-dependent communities" throughout this book.

11 See Frances Seymour, "Forests, climate change and human rights: managing risks and tradeoffs" in Stephen Humphreys, ed., Human Rights and Climate Change (Cambridge, UK: Cambridge University Press, 2009) 207-237; Annalisa Savaresi, "The Human Rights Dimension of REDD" (2012) 21:2 Review of European Community E International Environmental Law 102; Thomas Sikor \& Johannes Stahl, eds., Forests and People. Property, Governance, and Human Rights (London, UK: Earthscan, 2011) 237; Heike Schroeder \& Constance McDermott, "Beyond Carbon: Enabling Justice and Equity in REDD+ Across Levels of Governance" (2014) 19:1 Ecology \& Society 31; Robert Fischer \& Rosemary Lyster, 
Peoples and local communities, as well as opportunities to foster their participation in forest governance and support their sustainable livelihoods. ${ }^{12}$ On the other hand, given their technocratic focus on carbon sequestration and potential to generate unintended incentives for land grabbing, REDD+ activities may marginalize the interests and perspectives of forest-dependent populations and dispossess them of their traditional rights to forests, lands, and resources. ${ }^{13}$ This array of potential synergies and tensions between REDD+ and Indigenous and community rights has led some scholars to speak of REDD+ as a "paradox," since the very same set of factors that are seen as having the capacity to generate benefits for forest-dependent communities are also seen as posing significant risks to their rights, institutions, and livelihoods. ${ }^{14}$

This book seeks to shed light on the REDD+ paradox by providing an in-depth socio-legal study of the implications of REDD+ for the rights of Indigenous Peoples and local communities in developing countries. Broadly speaking, I adopt a new legal realist perspective that draws on empirical research to uncover the limited, yet no less potent, opportunities offered in and around the law for social change and justice. ${ }^{15}$ In particular, I conceive of the development and implementation of REDD+ activities around the world as amounting to a "transnational legal process," which I define as the construction and conveyance of legal norms across sites and levels of law that transcend the traditional territorial boundaries of sovereign states. ${ }^{16}$ I grapple with two important questions concerning the intersections between the transnational legal process for REDD+ and the rights of Indigenous Peoples and local communities. First, how have Indigenous and community rights been

"Land and resource tenure: The rights of indigenous peoples and forest dwellers" in Rosemary Lyster, Catherine Mckenzie \& Constance K. McDermott, eds., Law, Tropical Forests and Carbon: The Case of REDD+ (Cambridge, UK: Cambridge University Press, 2013) 187 .

12 Kathleen Lawlor et al., "Community Participation and Benefits in REDD+: A Review of Initial Outcomes and Lessons" (2013) 4:2 Forests 296.

13 Jesse Ribot \& Anne M. Larson, "Reducing REDD risks: Affirmative policy on an uneven playing field" (2012) 6(2) International Journal of the Commons 233.

14 Chris Sandbrook, Fred Nelson, William M. Adams \& Arun Agrawal, "Carbon, forests and the REDD paradox" (2010) 44:03 Oryx 330.

15 Howard Erlanger et al., "Is It Time for a New Legal Realism?" (2005) 2 Wisconsin Law Review 335; Sally Engle Merry, "New Legal Realism and the Ethnography of Transnational Law" (2006) 31:4 Law \& Social Inquiry 975.

16 Shaffer, supra note 62 at 234 (describing transnational legal processes as focusing on "the transnational production of legal norms and institutional forms and their migration across borders, regardless of whether they address transnational activities or purely national ones") and 235 (defining a transnational legal process as "the process through which the transnational construction and conveyance of legal norms takes place.") 
recognized across a range of international and transnational sites of law for REDD+? Second, whether, how, and to what extent has the pursuit of jurisdictional and project-based REDD+ activities affected the recognition and protection of Indigenous and community rights in developing countries? Through a combination of international legal analysis and in-depth empirical research on the pursuit of REDD+ activities in two case study countries, Indonesia and Tanzania, from 2005 to 2014 , this book contributes to our understanding of REDD+, its implications for human rights, and the influence of transnational legal processes. In what remains of this chapter, I review the existing literature on the relationship between REDD+ and rights. I then introduce the analytical framework and research design that underlie this book, discuss the significance and originality of my approach and findings, and outline the contents of the chapters that follow.

\section{EXISTING KNOWLEDGE}

The relationship between REDD+ and the rights of Indigenous Peoples and local communities has given rise to a burgeoning body of research across several disciplines. One stream of scholarship produced by legal scholars ${ }^{17}$ has argued that the design and management of REDD+ programs, policies, and projects should comply with the participatory rights of individuals and communities $^{18}$ enshrined in international human rights law $^{19}$ and recognized through the principle of public participation in international environmental law. ${ }^{20}$ In doing so, these scholars have emphasized that Indigenous Peoples benefit from an enhanced set of procedural rights by virtue of their recognition

17 Savaresi, supra note 11; Fischer \& Lyster, supra note 11; Annalisa Savaresi, "REDD+ and Human Rights: Addressing Synergies between International Regimes" (2013) 18:3 Ecology and Society art. 5; Rosemary Lyster, "REDD+, transparency, participation and resource rights: The role of law" (2011) 14:2 Environmental Science \& Policy 118; Sophie Lemaitre, "Indigenous Peoples' Land Rights and REDD: A Case Study" (2011) 20:2 Review of European Community \& International Environmental Law 150; Sébastien Jodoin, "The Human Rights of Indigenous Peoples and Forest-Dependent Communities in the Complex Legal Framework for REDD+" in Christina Voigt, ed., Research Handbook on REDD-plus and International Law (Cheltenham, UK: Edward Elgar, 2016) 157-185.

18 Savaresi, supra note 11 at 106; Rosemary Lyster, "REDD+, transparency, participation and resource rights: The role of law" (2011) 14:2 Environmental Science E. Policy 118 at 123-125.

19 The right to participation is most notably protected in the International Covenant on Civil and Political Rights, U.N. Doc. A/6316 (1966), entered into force 23 Mar. 1976, art. 25(a), which provides that every citizen has the right to "take part in the conduct of public affairs, directly or through freely chosen representatives."

20 See, e.g., Declaration on Environment and Development, Report of the United Nations Conference on Environment and Development, U.N. Doc. A/CONF.151/6/Rev.1 (1992), Principle 10 ("Environmental issues are best handled with the participation of all concerned 
as "peoples" ${ }^{21}$ and their right to self-determination under international law. ${ }^{22}$ As is recognized in the UNDRIP23, ILO Convention $169^{24}$ and the decisions of numerous international and regional human rights bodies, ${ }^{25}$ Indigenous Peoples have the right to provide or withhold their free, prior, and informed consent (FPIC) to activities and measures that affect their rights, lands, and resources. ${ }^{26}$ For their part, local or forest-dependent communities do not possess a distinct status ${ }^{27}$ or set of rights under international law, nor do

citizens, at the relevant level. At the national level, each individual shall have appropriate access to information concerning the environment that is held by public authorities, including information on hazardous materials and activities in their communities, and the opportunity to participate in decision-making processes. States shall facilitate and encourage public awareness and participation by making information widely available. Effective access to judicial and administrative proceedings, including redress and remedy, shall be provided.")

${ }^{21}$ While there is no universal definition of the term "Indigenous Peoples" under international law, there are a number of recognized criteria that can be used to understand and apply this term: "(i) priority in time, in terms of occupation and use of specific territory; (ii) voluntary perpetuation of cultural specificity, which can include aspects of their language, social organization, religion and spiritual values, modes of production, legal forms and institutions; (iii) self-identification, as well as recognition by other groups, or by State authorities, as differentiated collectives; and (iv) an experience of subjugation, marginalization, dispossession, exclusion or discrimination, whether these conditions persist or not" (Erica-Irene Daes, Chairperson-Rapporteur, "Working Paper on the concept of 'indigenous people'," (United Nations Economic and Social Council, 10 June 1996), UN Doc. E/CN.4/Sub.2/ AC.4/1996/2, at para. 69-70).

22 UNDRIP, art. 3, 4, and 5; ILO Convention 169, art. 6.1, 15.1, and 15.2. Article 19 of the UNDRIP most notably states that: "States shall consult and cooperate in good faith with the indigenous peoples concerned through their own representative institutions in order to obtain their free, prior and informed consent before adopting and implementing legislative or administrative measures that may affect them."

23 See UNDRIP, art. 10, 11(2), 19, 28, 29(2) and 32(2)).

24 ILO Convention 169, art. 4, 5 and 13-19.

25 See, e.g., I/A Court H.R., Maya Indigenous Communities and Their Members against Belize (Case No. 12.053), Report No. 40/04, 12 October 2004, at para. 142; I/A Court H.R., Saramaka People v. Suriname, Preliminary Objections, Merits, Reparations, and Costs, Judgment of 28 November, 2007, Series C No. 172, at para. 134; African Commission on Human and Peoples Rights, Centre for Minority Rights Development (Kenya) and Minority Rights Group International on behalf of Endorois Welfare Council (Case 276 / 2003), Judgement (2009) at para. 291.

26 Savaresi, supra note 11 at 106-107; Fischer \& Lyster, supra note 11 at 190-191. See also Jessica Rae, Mahala Gunther \& Lee Godden, "Governing Tropical Forests: REDD+, Certification and Local Forest Outcomes" (2011) 7:2 Macquarie Journal of International \& Comparative Environmental Law 40 at 66.

27 One influential definition of forest-dependent communities is the following: "A coherent, social group of persons with interests or rights related to forests or forest resources, in a particular area, which the persons hold or exercise communally in terms of an agreement, custom or law" (South African Development Community, South African Development Community Protocol on Forestry (Luanda, 3 October 2002) entered into force 17 July 2009, art. 2(1)). 
they hold explicit collective rights to their traditional lands and resources or to FPIC under any existing international instrument. ${ }^{28}$ They must instead assert a broad set of claims based on general international human rights law, the rights held by Indigenous Peoples, and the land and tenure rights that they may hold under national legal systems. ${ }^{29}$

Legal scholars have also considered whether and how the implementation of REDD+ policies, programs, and projects may affect a range of substantive human rights protected under international law. On the one hand, avoiding deforestation through REDD+ and equitably sharing the benefits generated by climate finance may serve to protect the traditional rights and territories of Indigenous Peoples and local communities, and contribute to their sustainable livelihoods..$^{30}$ On the other hand, any rules and restrictions imposed through a REDD+ program or project on local access to forests or use of resources may interfere with numerous human rights, ${ }^{31}$ including rights to personal security, freedom of movement, and freedom from racial discrimination, ${ }^{32}$ rights to housing, food, water, health, an adequate standard of living, and culture,,$^{33}$ and the sui generis rights to land, resources, and culture held by Indigenous Peoples ${ }^{34}$ under international law. ${ }^{35}$ In this regard, the potential creation, sale, and trading of property rights over the carbon sequestered in trees (known as "carbon rights") through project-based REDD+ activities have been identified as especially problematic on the grounds that this process of commodification may be contrary to Indigenous conceptions of property, interfere with the unique relationship that Indigenous Peoples enjoy with nature, and serve to dispossess them of their lands and resources. ${ }^{36}$

28

Environmental Law 71 at 92-94.

29 Sikor \& Stahl, supra note 11 at 8.

32

International Covenant on Civil and Political Rights, adopted 16 Dec. 1966, UNGA Res. $2200 A$ (XXI), 21 U.N. GAOR Supp. (No. 16) at 52, U.N. Doc. A/6316 (1966), 999 U.N.T.S. 171, entered into force 23 Mar. 1976, art. 9(1), 12(1), and 26(1).

33 International Covenant on Economic, Social and Cultural Rights, adopted 16 Dec. 1966, UNGA Res. 2200A (XXI), 21 U.N. GAOR Supp. (No. 16) at 49, U.N. Doc. A/6316 (1966), 993 U.N.T.S. 3, entered into force 3 Jan. 1976, art. 11, 12, and 15.

34 Fischer \& Lyster, supra note 11 at 193-206; Lemaitre, supra note 17 at 152-156.

35 See, e.g., UNDRIP, art. 10, 11, 12 13, 15, 20, 25, 26, 27, 29, 31, and 32; Inter-American Court of Human Rights 31 August 2001, Mayagna (Sumo) Awas Tingni Community v. Nicaragua, Series C, No. 79, at 153; Yanomami Indians v. Brazil, IACtHR Case 7615, OEA/ser. L/V/ II.66, doc. 10 rev. 1 (1985), 1984-1985 Annual Report 24; Case of the Indigenous Community Yakye Axa v. Paraguay, Merits, Reparations and Costs, Judgment, Inter-Am. Ct. H.R. (ser. C) No. 125 (17 June, 2005).

${ }^{6}$ Kathleen Birrell, Lee Godden \& Maureen Tehan, "Climate change and REDD+: Property as a prism for conceiving Indigenous peoples' engagement” (2012) 3:2 Journal of Human Rights and the Environment 196. 
Legal scholars have expressed a general lack of confidence in the effectiveness of the social and environmental safeguard initiatives that have emerged across multilateral, bilateral, and nongovernmental initiatives for REDD+ to prevent or mitigate its adverse social implications for local populations. ${ }^{37}$ It is worth remembering that the recognition of the status and rights of Indigenous Peoples under international law remains controversial in many developing countries, especially in Africa and Asia. Indeed, many governments in Africa and Asia have denied that the very concept of Indigenous Peoples apply in their countries, arguing that it is the product of European colonial settlement in the Americas and that its application is restricted to that region. ${ }^{38}$ In the face of these challenges, many legal scholars have called for the development of formally binding mechanisms at the international level to ensure the protection of human rights within the context of REDD+, whether through the UNFCCC or established United Nations human rights bodies. ${ }^{39}$

A second strand of research, anchored in environmental studies, has focused on the extent to which REDD+ may support or detract from the recognition and protection of the collective forest and land tenure rights and institutions of local communities, ${ }^{40}$ particularly in terms of the pursuit and implementation of community forestry. ${ }^{41}$ This literature reveals three broad ways in which REDD+ may support the rights and institutions of local communities. First, REDD+ activities may in and of themselves serve as

37 See, e.g., Grit Ludwig, "Property Rights and Participation in REDD+: The Case of Mozambique" (2012) 1:2 Transnational Environmental Law 381 at 398-401; Lemaitre, supra note 17 at $160-162$.

$3^{8}$ Benedict Kingsbury, “'Indigenous Peoples' in International Law: A Constructivist Approach to the Asian Controversy" (1998) 92:3 American Journal of International Law 414; Alexandra Xanthaki, Indigenous Rights and United Nations Standards: Self-Determination, Culture and Land (Cambridge, Cambridge University Press, 2007) at 34.

39 See generally Christoph Schwarte, "Social Safeguards in REDD: A review of possible mechanisms to protect the rights and interests of indigenous and forest-dependent communities in a future system for REDD” (2010) 6:1 McGill Journal of Sustainable Development Law E Policy 57; David J. Kelly, "The Case for Social Safeguards in a Post-2012 Agreement on REDD" (2010) 6:1 Law, Environment and Development Journal 61; Savaresi, supra note 11 at 112-113; Savaresi, supra note 17 at 5-6; Naomi Roht-Arriaza, "Human rights in the climate change regime" (2010) 1:2 Joumal of Human Rights and the Environment 211 at 234.

$4^{\circ}$ Thomas Sikor et al., "REDD-plus, forest people's rights and nested climate governance" (2010) 20:3 Global Environmental Change 423.

${ }^{41}$ Community forestry is defined in broad terms here as an approach that recognizes, protects, and supports the collective rights, authority, and capacity of local communities to govern, access, and benefit from the forests within which they live or upon which they depend. For an overview of the concept of community forestry, see J.E.M. Arnold, "Forests and people: 25 years of community forestry" (Rome, Italy: Food and Agriculture Organization of the United Nations, 2001), available at www.treesforlife.info/fao/Docs/P/25y.pdf. 
a vehicle for the pursuit of community forestry ${ }^{42}$ or the recognition and protection of rights to forests and land tenure, ${ }^{43}$ due to their purported benefits for reducing deforestation and enhancing carbon sequestration. ${ }^{44}$ On a broader scale, numerous scholars have argued that the adoption and implementation of laws and schemes to clarify and regularize the forest tenure rights of forest-dependent communities should form a pre-condition or starting point for the jurisdictional REDD+ readiness efforts pursued by developing countries. ${ }^{45}$ In this regard, early studies demonstrate that REDD+ readiness efforts and projects have indeed made some contribution to forest tenure reforms ${ }^{4}$ while also highlighting the complex challenges that they face in addressing the political conflicts and technical challenges that stand in their way. ${ }^{47}$ Second, the equitable distribution of funds for REDD+ activities among local communities (a practice known as "benefit-sharing") may support their sustainable livelihoods and provide some of the long-term finance required to sustain the implementation of community forestry arrangements..$^{4}$ Third, Indigenous Peoples and local communities may also benefit from being involved in the

42 Tanya Hayes \& Lauren Persha, "Nesting local forestry initiatives: Revisiting community forest management in a REDD+ world” (2010) 12(8) Forest Policy \& Economics 545; Maria Fernanda Tomaselli \& Reem Hajjar, "Promoting Community Forestry Enterprises in National REDD+ Strategies: A Business Approach” (2011) 2:1 Forests 283; Peter Cronkleton, David Barton Bray \& Gabriel Medina, "Community Forest Management and the Emergence of Multi-Scale Governance Institutions: Lessons for REDD+ Development from Mexico, Brazil and Bolivia” (2011) 2:2 Forests 451 at 465; Randy Bluffstone, Elizabeth Robinson \& Paul Guthiga, "REDD+ and community-controlled forests in low-income countries: Any hope for a linkage?” (2013) 87 Ecological Economics 43; Harini Nagendra \& Elinor Ostrom, "Polycentric governance of multifunctional forested landscapes" (2012) 6:2 International Journal of the Commons 104.

43 Kathleen Lawlor et al., supra note 12 at 304-311. See also André Rodrigues de Aquino, André Aasrud \& Leticia Guimarães, "Can Forest Carbon Finance Influence Land Tenure Security in Project Areas? Preliminary Lessons from Projects in Niger and Kenya” (2011) 8 Advances in Agroforestry 231.

44 Ashwini Chhatre \& Adrun Agrawal, "Tradeoffs and synergies between carbon storage and livelihood benefits from forest commons" (2009) 106(42) Proceedings of the National Academy of Sciences 17667 .

45 Ibid. See also Ashwini Chhatre et al., "Social safeguards and co-benefits in REDD+: A review of the adjacent possible” (2012) 4:6 Current Opinion in Environmental Sustainability 654 at 656.

$4^{6}$ Amy Duchelle et al., "Linking Forest Tenure Reform, Environmental Compliance, and Incentives: Lessons from REDD+ Initiatives in the Brazilian Amazon” (2014) 55 World Development 53 at 64 .

47 Esteve Corbera et al., "Rights to Land, Forests and Carbon in REDD+: Insights from Mexico, Brazil and Costa Rica" (2011) 2 Forests 301; William D. Sunderlin et al., "How are REDD+ Proponents Addressing Tenure Problems? Evidence from Brazil, Cameroon, Tanzania, Indonesia, and Vietnam" (2014) 55 World Development 37.

$4^{8}$ Leo Peskett, "REDD+ and Development" in Lyster, MacKenzie \& McDermott, supra note $11,230$. 
monitoring, reporting, and verification of forest carbon stocks in the implementation of REDD+ policies, programs, and projects. ${ }^{49}$

On the other hand, many scholars have expressed concerns that REDD+ activities are likely to have adverse consequences for local communities. Many scholars have warned that the technical complexities and national scale of jurisdictional REDD+ activities have the potential to prompt central authorities to seek to assert greater control over forests and accordingly reduce their willingness to devolve authority over forests to local communities. ${ }^{50}$ Moreover, many authors note that the potential of REDD+ funds to make a significant difference to the lives of forest-dependent communities may be constrained by the low price of carbon on voluntary carbon markets. ${ }^{51}$ Given the limitations and inequities of existing forest governance systems, scholars argue that the introduction of funds through REDD+ projects and schemes may create new opportunities for corruption, graft, and capture by central or local elites ${ }^{52}$ and thus further induce central forest authorities to maintain or increase their control over forests. ${ }^{53}$

Due to the limitations of the social and environmental safeguards that have been developed by multilateral, bilateral, and nongovernmental actors for REDD+ activities, ${ }^{54}$ a number of authors argue that REDD+ activities

49 Ben Palmer Fry, "Community forest monitoring in REDD+: The 'M' in MRV?" (2011) 14:2 Environmental Science and Policy 181; Margaret Skutsch, ed., Community Forest Monitoring for the Carbon Market: Opportunities Under REDD (London, UK, Earthscan, 2011); Alejandra Larrazábal, Michael K. McCall, Tuyeni H. Mwampamba \& Margaret Skutsch, "The role of community carbon monitoring for REDD+: a review of experiences" (2012) Current Opinion in Environmental Sustainability 707.

5० Jacob Phelps, Edward L. Webb \& Arun Agrawal, "Does REDD+ threaten to recentralize forest governance?” (2010) (80) Science 312. See also Betsy A. Beymer-Farris \& Thomas J Bassett, "The REDD menace: Resurgent protectionism in Tanzania's mangrove forests" (2012) 22:2 Global Environmental Change 332.

${ }^{1}$ Eliakimu Zahabu \& Rogers E. Malimbwi, "The Potential of Community Forest Management under REDD+ for Achieving MDG Goals in Tanzania" in Margaret Skutsch, ed., Community Forest Monitoring for the Carbon Market: Opportunities Under REDD (London, UK, Earthscan, 2011) 134 at 146.

52 Emma Doherty \& Heike Schroeder, "Forest Tenure and Multi-level Governance in Avoiding Deforestation under REDD+" (2011) 11:4 Global Environmental Politics 66-88 at 81; Seymour, supra note 11 at 219.

53 Anne M. Larson, "Forest tenure reform in the age of climate change: Lessons for REDD+" (2011) 21:2 Global Environmental Change 540 at 547.

54 Constance L. McDermott et al., "Operationalizing Social Safeguards in REDD+: Actors, Interests and Ideas" (2012) 21 Environmental Science \& Policy 63; Theresa de la Fuente \& Reem Hajjar, "Do current forest carbon standards include adequate requirements to ensure indigenous peoples' rights in REDD projects?" (2013) 15:4 International Forestry Review 1; Isabel Melo, Esther Turnhout \& Bas Arts, "Integrating multiple benefits in market-based climate mitigation schemes: The case of the Climate, Community and Biodiversity certification scheme" (2014) 35:2009 Environmental Science \& Policy 49; Sango Mahanty \& Constance L. McDermott, "How does 'Free, Prior and Informed Consent' (FPIC) impact social equity? Lessons from mining and forestry and their implications for REDD+" (2013) 35 Land Use Policy 406. 
are unlikely to yield fair and just outcomes for Indigenous Peoples and forestdependent communities in the absence of broader reforms aimed at improving governance systems and creating locally accountable institutions in the forestry sector. ${ }^{55}$ Many scholars fear that REDD+ may function as a form of environmental governance that promotes technocratic and market-oriented approaches to forest governance ${ }^{56}$ and marginalizes traditional and community perspectives. ${ }^{57}$ In light of the entrenched political, economic, and legal asymmetries that characterize forest governance in many developing countries, ${ }^{5}$ Ribot and Larson raise important questions about the likelihood that REDD+ may harm, rather than benefit, local populations:

REDD is entering this slanted world with the primary objective of carbon emissions reduction - not justice or equity. If community rights are already limited (...) will they be limited in the future under REDD in the name of carbon sequestration? Who will control forests? What rules for resource use will be developed to meet carbon targets under REDD, who will create and enforce these rules and how might they limit community access to forests for livelihoods? If communities carry new burdens - such as limitations on activities permitted in forests ('no' imposed from above) - will they be fairly compensated? Will the rights to forest benefits - this time to carbon funds once again be captured by outsiders? ${ }^{59}$

As summarized in Table I.1, the existing literature provides a helpful overview of the range of potential implications of REDD+ activities for the participatory

55 See, e.g., Kathleen Lawlor, Erika Weinthal \& Lydia Olander, "Institutions and Policies to Protect Rural Livelihoods in REDD+ Regimes" (2010) 10:4 Global Environmental Politics 1; Anne M. Larson \& Elena Petkova, "An Introduction to Forest Governance, People and REDD+ in Latin America: Obstacles and Opportunities" (2011) 2:1 Forests 86-111; Anna Knox et al., "Land Tenure and Payment for Environmental Services: Challenges and Opportunities for REDD+" (2011) 11:2 Land Tenure Journal 17-55.

56 See Mary C. Thompson, Manali Baruah \& Edward R. Carr, "Seeing REDD+ as a project of environmental governance" (2011) 14:2 Environmental Science \& Policy 100; Thomas Sikor, "REDD+: Justice effects of technical design" in Thomas Sikor, ed., Justices and Injustices of Ecosystem Services (Abingdon, UK: Routledge, 2013) 46.

57 Irmeli Mustalahti et al., "Can REDD+ Reconcile Local Priorities and Needs with Global Mitigation Benefits? Lessons from Angai Forest, Tanzania" (2012) 17:1 Ecology ש Society 16; Pablo Reed, "REDD+ and the Indigenous Question: A Case Study from Ecuador" (2011) 2:2 Forests 525; Matthew Leggett \& Heather Lovell (2012) "Community perceptions of REDD+: A case study in PNG" (2012) 12:1 Climate Policy 115.

$5^{8}$ Maxwell Gomera, Liz Rihoy \& Fred Nelson, "A Changing Climate for Community Resource Governance: Threats and Opportunities from Climate Change and the Emerging Carbon Market" in Fred Nelson, eds., Community Rights, Conservation and Contested Land: The Politics of National Resource Governance in Africa (London, UK: Earthscan, 2010) 293.

59 Ribot \& Larson, supra note 13 at 248. 
TABLE I.1. Overview of the potential implications of REDD+ for the rights of Indigenous Peoples and forest-dependent communities

\begin{tabular}{|c|c|c|c|}
\hline Type of right & Definition & Positive implications & Negative implications \\
\hline $\begin{array}{l}\text { Participatory } \\
\text { Rights }\end{array}$ & $\begin{array}{l}\text { Under general principles of } \\
\text { international human rights } \\
\text { law and international } \\
\text { environmental law, Indigenous } \\
\text { Peoples and forest-dependent } \\
\text { communities have rights to fully } \\
\text { and effectively participate in the } \\
\text { design and implementation of } \\
\text { programs, policies, and projects } \\
\text { that affect their rights and to }\end{array}$ & $\begin{array}{l}\text { REDD+ activities may promote the } \\
\text { participation and engagement of } \\
\text { Indigenous Peoples and forest- } \\
\text { dependent communities in the design } \\
\text { and implementation of relevant } \\
\text { policies, programs, and projects, } \\
\text { including through community-based } \\
\text { forms of MRV. This in turn may help } \\
\text { to ensure that the knowledge of } \\
\text { Indigenous Peoples and forest- }\end{array}$ & $\begin{array}{l}\text { REDD+ may promote technocratic and market- } \\
\text { oriented approaches that do not engage with } \\
\text { Indigenous Peoples and forest-dependent } \\
\text { communities, that ignore their participatory } \\
\text { rights, and that marginalize their } \\
\text { perspectives. REDD+ activities may reflect } \\
\text { the priorities of governments, corporations, } \\
\text { and NGOs rather than the needs of local } \\
\text { populations due to entrenched political and } \\
\text { economic asymmetries in forest governance. }\end{array}$ \\
\hline
\end{tabular}

access administrative, judicial, and other accountability mechanisms in case of human rights violations. Due to their unique status under international law, Indigenous Peoples also possess the right to provide or withhold FPIC in relation to measures that affect their traditional lands and rights.

dependent communities is integrated in design and implementation processes. oriented approaches that do not engage with ndigenous Peoples and forest-dependent rights, and that marginalize their perspectives. REDD+ activities may reflect economic asymmetries in forest governance. 
TABLE I.1. (continued)

\begin{tabular}{|c|c|c|c|}
\hline Type of right & Definition & Positive implications & Negative implications \\
\hline $\begin{array}{c}\text { Substantive } \\
\text { Rights }\end{array}$ & $\begin{array}{l}\text { As a result of their rights to } \\
\text { personal security, freedom of } \\
\text { movement, and freedom from } \\
\text { racial discrimination as well as } \\
\text { their economic, social, and } \\
\text { cultural rights, Indigenous } \\
\text { Peoples and forest-dependent } \\
\text { communities have rights to } \\
\text { access, govern, and benefit } \\
\text { from the forests in which they } \\
\text { live or upon which they } \\
\text { depend. Due to their unique } \\
\text { status under international law, } \\
\text { Indigenous Peoples possess sui } \\
\text { generis rights to their traditional } \\
\text { lands and resources. Finally, } \\
\text { international human rights law } \\
\text { also provides Indigenous } \\
\text { Peoples and forest-dependent } \\
\text { communities with economic, } \\
\text { social, and cultural rights to } \\
\text { housing, food, water, health, an } \\
\text { adequate standard of living, } \\
\text { and culture. }\end{array}$ & $\begin{array}{l}\text { REDD+ activities may in and of } \\
\text { themselves protect the traditional } \\
\text { territories of Indigenous Peoples and } \\
\text { forest-dependent communities from } \\
\text { deforestation and forest degradation. } \\
\text { They may also provide new funding } \\
\text { and momentum for clarifying and } \\
\text { strengthening the forest, land tenure, } \\
\text { and resource rights of Indigenous } \\
\text { Peoples and forest-dependent } \\
\text { communities, both in terms of national } \\
\text { policy reforms as well as in the context } \\
\text { of particular projects. Indeed, given the } \\
\text { posited advantages of community } \\
\text { forestry for the sustainable management } \\
\text { of forests and carbon sequestration, } \\
\text { community forestry policies and } \\
\text { institutions could serve as the very basis } \\
\text { for the design and implementation of } \\
\text { REDD+ activities. Finally, REDD+ } \\
\text { activities may generate new funds that } \\
\text { could alleviate poverty among } \\
\text { Indigenous Peoples and forest- } \\
\text { dependent communities, support their } \\
\text { sustainable livelihoods, and sustain the } \\
\text { implementation of community forestry } \\
\text { arrangements and institutions. }\end{array}$ & $\begin{array}{l}\text { The political economy of forest governance in } \\
\text { developing countries makes it unlikely that } \\
\text { issues around forest and land tenure will be } \\
\text { resolved to the benefit of Indigenous Peoples } \\
\text { and forest-dependent communities. Due to } \\
\text { their complexity and the new and additional } \\
\text { rents that they will generate, REDD+ activities } \\
\text { may induce public and private actors to } \\
\text { maintain or increase their control over forests, } \\
\text { to favor other types of interventions to } \\
\text { community forestry, and to ignore, abrogate, } \\
\text { or violate the forest, land tenure, and resource } \\
\text { rights of Indigenous Peoples and forest- } \\
\text { dependent communities. Moreover, to the } \\
\text { extent that they lead to the commodification } \\
\text { of carbon, REDD+ activities may be contrary } \\
\text { to Indigenous conceptions of property and } \\
\text { interfere with the unique relationship that } \\
\text { Indigenous Peoples enjoy with nature. Finally, } \\
\text { given the limitations and inequities of existing } \\
\text { forest governance systems, the introduction of } \\
\text { funds through REDD+ projects and schemes } \\
\text { may create new opportunities for corruption, } \\
\text { graft, and capture by central or local elites, } \\
\text { thus further contributing to the } \\
\text { socioeconomic marginalization of Indigenous } \\
\text { Peoples and forest-dependent communities. }\end{array}$ \\
\hline
\end{tabular}


and substantive rights of Indigenous Peoples and local communities. ${ }^{60}$ Of course, much of this literature was produced in the initial stages of the global operationalization of REDD+, without the benefit of empirical research on its processes and outcomes. Given the advanced stage that REDD+ has reached around the world, the primary purpose of this book lies in subjecting these claims to empirical scrutiny in order to understand whether, how, and to what effect the pursuit of REDD+ has affected the rights of Indigenous Peoples and local communities in developing countries.

\section{ANALYTICAL FRAMEWORK}

In order to capture the diverse ways in which REDD+ has affected Indigenous and community rights, I develop and employ an interdisciplinary analytical framework for the study of transnational legal processes. Since Koh first coined this term in the mid-19gos to analyze the multiple pathways through which states internalize rules of international law, ${ }^{6}$ a number of socio-legal scholars, especially Shaffer and Halliday, have expanded the study of these processes by focusing on the broader set of legal norms that may be constructed and conveyed across borders, and the manifold ways in which they may influence economic, social, and political institutions and processes. ${ }^{62}$ This scholarship has dovetailed with work examining the diffusion, transplantation, or translation of legal norms across diverse sites of law. ${ }^{63}$

6o While I distinguish between participatory and substantive rights for the sake of analytical clarity throughout this book, I recognize that these rights are intertwined with one another in legal and practical terms. For instance, although the right to FPIC is included here as a participatory right, it could also be framed as a substantive right because it is closely associated with the notion that Indigenous Peoples possess sui generis land and resource rights. See Jérémie Gilbert \& Cathal Doyle, "A New Dawn over the Land: Shedding Light on Collective Ownership and Consent" in Stephen Allen \& Alexandra Xanthaki, eds., Reflections on the UN Declaration on the Rights of Indigenous Peoples (Portland, Oregon: Hart Publishing, 2011) 289.

61 Harold Hongju Koh, "Transnational Legal Process" (1996) 75 Nebraska Law Review 181.

62 Gregory Shaffer, "Transnational Legal Process and State Change" (2012) 37:2 Law E Social Inquiry 229; Terence C. Halliday \& Bruce Carruthers, Bankrupt: Global Lawmaking and Systematic Financial Crisis (Stanford, CA: Stanford University Press, 2009); Terence Halliday \& Gregory Shaffer, eds., Transnational Legal Orders (Cambridge, UK: Cambridge University Press, 2015).

63 See, e.g., William Twining, "Diffusion of Law: A Global Perspective" (2004) 49 Journal of Legal Pluralism É Unofficial Law 1; Alan Watson, Legal Transplants (Athens, GA.: University of Georgia Press, 1993); Jonathan Miller, "A Typology of Legal Transplants: Using Sociology, Legal History and Argentine Examples to Explain the Transplant Process" (2003) 51 American Journal of Comparative Law 839; Toby S. Goldbach, Benjamin Brake \& Peter J. Katzenstein, "The Movement of U.S. Criminal and Administrative Law: Processes of Transplanting and Translating" (2013) 20:1 Indiana Journal of Global Legal Studies 141; Benjamin Brake \& Peter 
This rich body of scholarship has five important implications for the study of transnational legal processes. First, it suggests that a heterogeneous array of public and private actors, including international organizations, governments, nongovernmental organizations, corporations, communities, and individuals, are engaged in the construction and conveyance of legal norms across borders. ${ }^{6}$ Second, it posits that a transnational legal process may feature a multiplicity of sites, modes, and forms of ordering that are not subsumed within a state-centric conception of law ${ }^{65}$ and that encompass and cut across international, transnational, national, and subnational levels of governance. ${ }^{66}$ Third, it conceives of the construction and conveyance of legal norms as multidirectional - taking place horizontally between sites of law located at the same level and vertically from the "top-down" as well as the "bottom-up" across sites of law located at different levels. ${ }^{67}$ Fourth, far from viewing a transnational legal process as entailing the objective creation, interpretation, and application of law, this scholarship recognizes instead that the construction and conveyance of legal norms is contingent on both interest-driven and norm-driven behavior. ${ }^{68}$ Fifth, it stresses the importance of distinguishing between enactment, which consists of the formal acceptance of a legal norm within a site of law, and implementation, which refers to the practical application of a legal norm, as reflected in actual changes in the behavior of public and private actors. ${ }^{69}$ The enactment and implementation of legal norms can

J. Katzenstein, "Lost in Translation? Nonstate Actors and the Transnational Movement of Procedural Law" (2013) 67:4 International Organization 725-757; Jean-Frédéric Morin \& Richard Gold, "An Integrated Model of Legal Transplantation: The Diffusion of Intellectual Property Law in Developing Countries" (2014) 58 International Studies Quarterly 781.

64 Shaffer, supra note 62 at 236; Brake \& Katzenstein, supra note 63 at $731-737$; Koh, supra note 61 at 183-184; Edward S. Cohen, "The Harmonization of Private Commercial Law: The Case of Secured Finance" in Christian Brüutsch \& Dirk Lehmkuhl, eds., Law and Legalization in Transnational Relations (Abingdon, UK: Routledge, 2007) 58 at 63.

65 Adopting a legal pluralist conception of law, I define legal norms as norms that aim to constrain and facilitate the behavior and interactions of actors to whom they are addressed and that differ from social norms by their greater degree of clarity, formalization, and binding authority. See Terence Halliday \& Gregory Shaffer, "Transnational Legal Orders" in Halliday \& Shaffer, supra note 62, 3 at 11; Alec Stone Sweet, Governing with Judges: Constitutional Politics in Europe (Oxford, UK: Oxford University Press, 2000) at 11; Shaffer, supra note 62 at 234 .

66 Halliday \& Shaffer, supra note 65 at $43-44 . \quad{ }^{6} 7 \quad$ Shaffer, supra note 62 at 257.

68 Koh, supra note 61 at 205; Terence C. Halliday \& Bruce G. Carruthers, "The Recursivity of Law: Global Norm Making and National Lawmaking in the Globalization of Corporate Insolvency Regimes" (2007) 112:4 American Journal of Sociology 1135 at 1153.

69 This reflects the classic distinction between law-on-the-books and law-in-practice (Mathieu Deflem, Sociology of Law: Visions of a Scholarly Tradition (Cambridge, UK: Cambridge University Press, 2008) at 100-101) or what Halliday and Carruthers call the politics of enactment and the politics of implementation (Halliday \& Carruthers, supra note 62 at 406 ). 
have wide-ranging effects within a site of law, by engendering changes in the substance of law and policy, affecting institutions, and shaping the ideas, identities, and behavior of public and private actors. ${ }^{70}$

My analytical framework builds on this socio-legal literature by specifying the key causal mechanisms ${ }^{71}$ that drive the construction and conveyance of legal norms in a transnational legal process. Drawing on the findings of political scientists regarding the emergence and effectiveness of international norms ${ }^{72}$ the domestic influence of international law, ${ }^{73}$ and the nature of transnational processes of policy change ${ }^{74}$ I identify a range of rationalist ${ }^{75}$ and constructivist ${ }^{76}$ causal mechanisms that underlie the development of legal norms by actors within a site of law (construction) and their transmission in a

70 Shaffer, supra note 62 at 243-247; Harold Hongju Koh, "1998 Harris Lecture: How Is International Human Rights Law Enforced?” (1999) 74 Indiana Law Journal 1397 at 1413.

${ }^{71}$ John Campbell, Institutional Change and Globalization (Oxford, UK: Oxford University Press, 2004) at 61-64 (discussing the importance of causal mechanisms to social scientific explanations of institutional change).

$7^{2}$ Martha Finnemore \& Kathryn Sikkink, "International Norm Dynamics and Political Change” (1998) 52:4 International Organization 887-917; Ryan Goodman \& Derek Jinks, Socializing States: Promoting Human Rights Through International Law (Oxford, UK: Oxford University Press, 2013); Thomas Risse, Stephen C. Ropp \& Kathryn Sikkink, eds., The Persistent Power of Human Rights: From Commitment to Compliance (Cambridge, UK: Cambridge University Press, 2013).

73 Beth A. Simmons, Mobilizing for Human Rights: International Law in Domestic Politics (Cambridge: Cambridge University Press, 2010).

74 Frank Dobbin, Beth Simmons \& Geoffrey Garrett, “The Global Diffusion of Public Policies: Social Construction, Coercion, Competition, or Learning?" (2007) 33 Annual Review of Sociology 449-472; Mitchell A. Orenstein, Privatizing Pensions: The Transnational Campaign for Social Security Reform (Princeton, NJ: Princeton University Press, 2008); Steven Bernstein \& Benjamin Cashore, "Complex Global Governance and Domestic Policies: Four Pathways of Influence” (2012) 88:3 International Affairs 585-604.

75 Rationalist explanations posit that incentive structures or material constraints affect the behavior of actors. They assume that actors have fixed identities and interests, that they are rational, and that they seek to maximize their preferences in contexts in which they are constrained by the competing preferences of other actors, the checks imposed by institutions, and their limited capabilities (see generally Duncan Snidal, "Rational Choice and International Relations" in Carlsnaes, Risse \& Simmons, supra note 73, 85).

$7^{6}$ Constructivist explanations focus on the role that norms, including legal norms, play in shaping the behavior of actors. Norms in this context are understood as the intersubjective understandings that set standards of appropriate behavior for actors (Finnemore \& Sikkink, supra note 72 at 891), constitute their identities and their interests (Peter Katzenstein, ed., The Culture of National Security: Norms and Identity in World Politics (New York, NY: Columbia University Press, 1996); Martha Finnemore, National Interests in International Society (Ithaca, NY: Cornell University Press, 1996)), and enable them to give meaning to the world (Nicholas G. Onuf, World of Our Making (Colombia, SC: University of South Carolina Press, 1989); Alexander Wendt, "Anarchy is What States Make of It: The Social Construction of Power Politics” (1992) 46 International Organization 391; Peter Berger \& Thomas Luckmann, The Social Construction of Reality (London, UK: Penguin Books, 1996). 
relatively reified manner from one site of law to another (conveyance). ${ }^{77}$ As such, I assume that both rationalist and constructivist approaches are needed to provide a full account of how law relates to society, ${ }^{78}$ in large part because the relationship between interest-driven behavior and norm-driven behavior often plays a determinative role in the emergence, evolution, and effectiveness of institutions. ${ }^{79}$ That said, I accord little importance to whether a mechanism is best understood as rationalist or constructivist, nor do I aim to prove that one type of mechanism is more causally significant than the other. In presenting these causal mechanisms in the paragraphs that follow, I explain how they operate, specify their scope conditions, and highlight the importance of understanding how they may interact with one another in concurrent or sequential ways. I conclude this presentation of my analytical framework by discussing the relationship between the construction and conveyance of legal norms and delineating how transnational legal processes may result in the transplantation as well as translation of legal norms across sites of law (Table I.2).

This analytical framework is ideally suited for understanding the implications of REDD+ for the rights of Indigenous Peoples and local communities in developing countries. It enables me to trace the causal mechanisms that can explain whether and how legal norms relating to these rights have been constructed and conveyed across multiple forms, sites, and levels of law in the context of REDD+, and to what extent they may meaningfully affect the lives of Indigenous Peoples and local communities on the ground. To be sure, my analytical framework does not do justice to the richness of the many scholarly sources that it draws upon, nor does it dwell on the many important ways in which they may conflict with one another. Rather, its purpose lies in providing the key elements that can be used to analyze and understand a complex transnational legal process like REDD+ that originates in, operates

77 It is important to recognize that distinguishing between the construction and conveyance of legal norms reflects a simplified representation of most transnational legal processes. In practice, the construction and conveyance of legal norms may be intertwined or overlap with one another. See Shaffer, supra note 62 at 257-258.

78 Stone Sweet, supra note 65 at 6-20; Jaye Ellis, "Fisheries Conservation in an Anarchical System: A Comparison of Rational Choice and Constructivist Perspectives" (2007) 3 Journal of International Law \& International Relations 1.

79 Jeffrey T. Checkel, "International Norms and Domestic Politics: Bridging the RationalistConstructivist Divide" (1997) 3:4 European Journal of International Relations 473; James G. March \& Johan P. Olsen, "The Institutional Dynamics of International Political Orders" (1998) 52:4 International Organization 943; Peter Hall, "Historical Institutionalism in Rationalist and Sociological Perspective" in James Mahoney \& Kathleen Thelen, eds., Explaining Institutional Change: Ambiguity, Agency, and Power (Cambridge, UK: Cambridge University Press, 2009) 204. 
TABLE I.2. The causal mechanisms in transnational legal processes

\begin{tabular}{ll}
\hline \hline The Construction of Legal Norms & $\begin{array}{l}\text { Cost-Benefit Commitment } \\
\text { Persuasive Argumentation }\end{array}$ \\
The Conveyance of Legal Norms & Coercion \\
& Cost-Benefit Adoption \\
& Instrumental Learning \\
& Mobilization \\
& Élite Internalization \\
& Acculturation \\
\hline \hline
\end{tabular}

through, and exerts influence upon a diversity of sites of law at the international, transnational, national, and local levels.

\section{The Construction of Legal Norms in a Transnational Legal Process}

I understand the construction of legal norms as resulting from the concurrent or sequential operation of two causal mechanisms: cost-benefit commitment and persuasive argumentation. I define cost-benefit commitment as the causal mechanism whereby actors commit to abiding by a certain standard of future behavior in order to maximize utility and achieve cooperative solutions to a collective action problem. ${ }^{80}$ This mechanism posits that self-interested actors develop legal norms based on a rational calculation that the expected benefits of commitment outweigh its costs. ${ }^{81}$ The construction of legal norms through cost-benefit commitment does not take place in a vacuum, however, and builds upon the legal norms and practices present in a site of law in order to craft redesigned solutions to achieve existing objectives or resolve existing problems (what Campbell calls substantive bricolage). ${ }^{82}$ In addition, the development of legal norms through cost-benefit commitment may also take place on the basis of legal norms transmitted from other sites of law. In this

8० Matthew Potoski \& Aseem Prakash, "A Club Theory Approach to Voluntary Programs" in Matthew Potoski \& Aseem Prakash, eds., Voluntary Programs: A Club Theory Approach (Cambridge, MA: MIT Press, 2006) 17-39; Ralph H. Espach, Private Environmental Regimes in Developing Countries: Globally Sown, Locally Grown (New York, NY: Palgrave Macmillan, 2009) at 18-22; Lars H. Gulbrandsen, Transnational Environmental Governance: The Emergence and Effects of the Certification of Forests and Fisheries (Cheltenham, UK: Edward Elgar Press, 2010) at 18-20; Alec Stone Sweet, "Judicialization and the Construction of Governance” (1999) 32:2 Comparative Political Studies 147 at 152-154.

81 Judith Goldstein \& Lisa Martin, "Legalization, Trade Liberalization, and Domestic Politics," (2000) 54:3 International Organization 603-632. See also Beth A. Simmons, "International Law and State Behavior: Commitment and Compliance in International Monetary Affairs" (2000) 94:4 American Political Science Review 819.

82 Campbell, supra note 71 at 69. 
context, cost-benefit commitment will involve the rational adjustment or calibration of these legal norms in light of existing legal practices prevailing in a site of law. ${ }^{83}$

I define persuasive argumentation ${ }^{8}$ as the causal mechanism whereby actors construct and internalize a legal norm because they are convinced of its validity and appropriateness as a result of the shared understandings that they have developed with other actors. ${ }^{85}$ Existing research tells us that the construction of legal norms through persuasive argumentation depends upon the purposeful efforts of actors who seek to actively construct persuasive normative frames ${ }^{86}$ on the basis of legal norms prevailing in a site of law or originating from another site of law - a creative process known as framing. ${ }^{87}$ The existing literature also suggests that the effectiveness of persuasive argumentation is facilitated by three important conditions: the existence of a new situation or crisis in which actors are especially open to new normative understandings; ${ }^{88}$ the alignment between emergent or proposed legal norms and the existing legal norms internalized by actors; ${ }^{89}$ and a context in which actors engage in a primarily deliberative or participatory, rather than coercive, form of discourse..$^{\circ}$

Notwithstanding the very different causal logics that these two mechanisms embody and the different time frames in which they may operate, I view them as complementary explanations for the construction of legal norms within a site of law. ${ }^{91}$ For one, the construction of legal norms can result from the concurrent

83 Campbell, supra note 71 at 69.

84 Other terms that can be broadly considered equivalent with the notion of persuasive argumentation are socialization (Jeffrey T. Checkel, "International Institutions and Socialization in Europe: Introduction and Framework" (2005) 59:4 International Organization 801) and social learning (Peter Hall, "Policy Paradigms, Social Learning, and the State: The Case of Economic Policymaking in Britain” (1993) 25:3 Comparative Politics 275).

85 Goodman \& Jinks, supra note 72 at 24-25; Checkel, supra note 84 at 812-813; Thomas Risse, "'Let's Argue!': Communicative Action in World Politics” (2000) 54:1 International Organization 1; Jeffrey T. Checkel, "Why Comply? Social Learning and European Identity Change" (2001) 55:3 International Organization 553-588 at 562. See also Gulbrandsen, supra note 80 at 25-27.

86 Finnemore \& Sikkink, supra note 72 at 896-899.

87 Rodger Payne, "Persuasion, Frames and Norm Construction" (2001) 7:1 European Journal of International Relations 37 at 38-39. See also Campbell, supra note 71 at 70.

88 Checkel, supra note 79 at 562; Yves Dezalay \& Bryant Garth, Dealing in Virtue: International Commercial Arbitration and the Construction of a Transnational Legal Order (Chicago, IL: University of Chicago Press, 1996) at 5; Halliday \& Shaffer, supra note 65 at 35-36.

89 Shaffer, supra note 62 at 256. See also Richard Price, "Reversing the Gun Sights: Transnational Civil Society Targets Land Mines” (1998) 52:3 International Organization $613-644$ at $622-630$.

90 Risse, supra note 85 at 10-11; Checkel, supra note 85 at 563 ; Shaffer, supra note 62 at 249.

91 Kenneth W. Abbottet al., "The Concept of Legalization” (2000) 54:3 Intermational Organization 401 (discussing the complementarity of legal discourse based on reason and argument and political bargaining driven by self-interest); Gulbrandsen, supra note 80 at 28 (discussing the 
operation of both the causal mechanism of cost-benefit commitment (in that they embody the legal norms that actors have developed on a cost-benefit basis) and that of persuasive argumentation (in that they reflect the shared understandings that actors have constructed together). ${ }^{92}$ For another, the construction of legal norms can be seen as resulting from a specific temporal sequence in which one causal mechanism may be more important than another at different stages in the construction of legal norms. ${ }^{93}$ For my purposes, it suffices to note that the construction of legal norms within a site of law may be understood as a cycle that may combine or move back and forth between the causal mechanisms of cost-benefit commitment and persuasive argumentation.

\section{The Conveyance of Legal Norms in a Transnational Legal Process}

There is rich and extensive literature in law ${ }^{94}$ and political science ${ }^{95}$ on the various causal mechanisms that can explain the transmission or diffusion of laws, norms, policies, and institutions from one context to another. In Table I.3, I draw on this existing scholarship to identify six causal mechanisms

"interplay between the internalization of norms and rules and strategic-calculative decisions about participation in certification schemes and compliance with rules.")

92 Jutta Brunée \& Stephen Toope, Legitimacy and Legality in International Law: An Interactional Account (Cambridge, UK: Cambridge University Press, 2010) at 55 (arguing that international law results from "shared understandings of what [actors] want to accomplish through law, and of specific candidate norms."). See also Janet K. Levin, "Bottom-Up Lawmaking: The Private Origins of Transnational Law" (2008) 15 Indiana Joumal of Global Legal Studies 49.

93 See, e.g., Stone Sweet, supra note 80 (offering an account of judicialization that posits a shift from strategic behavior under dyadic modes of governance to normative structure under triadic modes of governance); Steven Bernstein \& Benjamin Cashore, "Can non-state global governance be legitimate? An analytical framework" (2007) 1 Regulation \& Governance 347 (developing a framework that posits a shift from a logic of consequences to a logic of appropriateness in the context of nonstate market-driven systems).

94 Leading typologies of the mechanisms of the diffusion of law include: Terence C. Halliday \& Pavel Osinsky, "Globalization of Law" (2006) 32 Annual Review of Sociology 447 (identifying modeling, nonreciprocal adjustment, capacity-building, suasion, coercion, and systems of rewards as mechanisms for the propagation of law); Brake \& Katzenstein, supra note 63 (identifying emulation, coercion, competition, and learning as mechanisms of the transnational movement of law); Halliday \& Carruthers, supra note 68 at 1153 (identifying coercion, persuasion, and modelling as modes of influence in the propagation of global norms); and Morin \& Gold, supra note 63 (identifying emulation, coercion, contractualization, regulatory competition, and socialization as causal mechanisms of the transplantation of law).

95 Leading typologies of mechanisms of transmission, diffusion, or influence include: Dobbin, Simmons \& Garrett, supra note 74 (identifying emulation, coercion, competition, and learning as causal mechanisms of policy diffusion); Orenstein, supra note 74 at 66 (identifying norms creation, norms teaching, and resource leveraging as modes of transnational policy influence); and Goodman \& Jinks, supra note 72 (describing material inducement, persuasion, and acculturation as mechanisms of social influence). 
TABLE I.3. The causal mechanisms of the conveyance of legal norms in a transnational legal process

\begin{tabular}{|c|c|}
\hline Causal mechanism & Causal focus and scope conditions \\
\hline Coercion & $\begin{array}{l}\text { The conveyance of legal norms is driven by the exercise of } \\
\text { material leverage by exogenous actors that forces endogenous } \\
\text { actors into enacting or implementing an exogenous legal } \\
\text { norm. }{ }^{96} \text { Its effectiveness depends on asymmetries in material } \\
\text { power between exogenous and endogenous actors }{ }^{97} \text { and on the } \\
\text { capacity and willingness of exogenous actors to detect and } \\
\text { sanction deviance, especially with respect to the } \\
\text { implementation of exogenous legal norms. }\end{array}$ \\
\hline $\begin{array}{c}\text { Cost-Benefit } \\
\text { Adoption }\end{array}$ & $\begin{array}{l}\text { The conveyance of legal norms is driven by the decision of } \\
\text { endogenous actors to enact or implement an exogenous legal } \\
\text { norm because the benefits of doing so exceed its costs (in } \\
\text { terms of reciprocity, }{ }^{99} \text { reputation }{ }^{100} \text { or economic gain). }{ }^{101} \text { Its } \\
\text { effectiveness depends on the precision and obligatory force } \\
\text { of exogenous legal norms and the availability of information } \\
\text { about their implementation. }{ }^{102}\end{array}$ \\
\hline $\begin{array}{c}\text { Instrumental } \\
\text { Learning }\end{array}$ & $\begin{array}{l}\text { The conveyance of legal norms is driven by the decision of } \\
\text { endogenous actors to enact or implement an exogenous legal } \\
\text { norm because they have acquired knowledge of the utility of } \\
\text { doing so from the experience of others. }{ }^{103} \text { Its effectiveness } \\
\text { depends on the ability of intermediaries to communicate and } \\
\text { promote this knowledge in a site of law. }{ }^{104}\end{array}$ \\
\hline
\end{tabular}

96 This responds to one of the criticisms made by Halliday and Shaffer about causal mechanisms, which they see as suggesting that law spreads in a necessarily "top-down" manner (Halliday \& Shaffer, supra note 65 at 37-38).

97 For a similar use of the terms endogenous and exogenous in relation to legal norms and processes, see, Halliday \& Carruthers, supra note 68.

98 Goodman \& Jinks, supra note 72 at 23 and 31-32; Orenstein, supra note 74 at 66.

99 Thomas Risse \& Stephen C. Ropp, "Introduction and Overview" in Risse, Ropp \& Sikkink, supra note 72, 3 at 20; Shaffer, supra note 62 at 253; Dobbin, Simmons \& Garrett, supra note 74 at 454-460; Bernstein \& Cashore, supra note 74 at 9-10; Halliday \& Carruthers, supra note 62 at 342.

100 Halliday \& Carruthers, supra note 62 at 351-354.

101 Beth A. Simmons, "Compliance with International Agreements" (1998) 1:1 Annual Review of Political Science $75-93$ at $80-81$.

102 Ibid. at 81.

103 Dobbin, Simmons \& Garrett, supra note 74 at $457-460$; Brake \& Katzenstein, supra note 63 at 746; Fabrizio Gilardi, “Transnational Diffusion: Norms, Ideas, and Policies” in Carlsnaes, Risse \& Simmons, supra note $73,453-477$ at $462-463$.

104 Abbott et al., supra note 91 at 408-415; Kenneth W. Abbott \& Duncan Snidal, "Hard and Soft Law in International Governance" (2009) 54:3 International Organization 421-456 at 426427; Potoski \& Prakash, supra note 80 at 22; Shaffer, supra note 62 at 251; Emilie HafnerBurton, Forced to Be Good: Why Trade Agreements Boost Human Rights (Ithaca, NY: Cornell University Press, 2009) at 160. 
TABLE I.3. (continued)

\begin{tabular}{|c|c|}
\hline Causal mechanism & Causal focus and scope conditions \\
\hline Mobilization & $\begin{array}{l}\text { The conveyance of legal norms is driven by the political or legal } \\
\text { pressure exerted upon endogenous actors by other } \\
\text { endogenous actors. }{ }^{105} \text { Its effectiveness depends on the } \\
\text { institutional, ideational, and material conditions that may } \\
\text { favor or constrain the emergence and mobilization of } \\
\text { endogenous interest groups and coalitions in favor of the } \\
\text { conveyance of exogenous legal norms. }\end{array}$ \\
\hline
\end{tabular}

Élite Internalization The conveyance of legal norms is driven by the internalization of exogenous legal norms by endogenous élite as a result of their participation in persuasive argumentation with exogenous actors. ${ }^{107}$ Its effectiveness depends on whether endogenous élites have the authority and capacity to enact and implement legal norms in a site of law. ${ }^{108}$

Acculturation The conveyance of legal norms is driven by the social and cognitive need for endogenous actors to enact or implement the exogenous legal norms widely accepted within their broader transnational reference group. ${ }^{109}$ Its effectiveness depends on the importance that the endogenous actor accords to their transnational reference group for their identity and the intensity and duration of their exposure to this group. ${ }^{110}$

Dobbin, Simmons \& Garrett, supra note 74 at $461-462$; Brake \& Katzenstein, supra note 63 at 747. This causal mechanism can be seen as related to the first type of legal transplant identified by Miller: the "cost-saving transplant" (Miller, supra note $6_{3}$ at $845-846$ ). Halliday \& Carruthers, supra note 62 at 302-306.

Checkel, supra note 79 at 557-558; Simmons, Mobilizing for Human Rights, supra note 73 at 7; Goodman \& Jinks, supra note 72 at 144-150.

There are two broad explanations that account for the effectiveness of mobilization in the existing literature: resource mobilization theory and opportunity structure. Resource mobilization theory posits that the effectiveness of mobilization depends on the capacity of interest groups to access and aggregate the array of ideational and material resources that they generate themselves or obtain from other actors (Bob Edwards \& Patrick F. Gillham, "Resource Mobilization Theory" Published online in The Wiley-Blackwell Encyclopaedia of Social and Political Movements (2013)). Opportunity structure, whether legal or political in nature, refers to the set of institutional, ideational, and material conditions that may favor or constrain the emergence and mobilization of interest groups and coalitions in favor of change and reform (Doug McAdam, "Conceptual Origins, Current Problems, Future Directions" in Doug McAdam, John D. McCarthy \& Mayer N. Zald, eds., Comparative Perspectives on Social Movements: Political Opportunities, Mobilizing Structures and Cultural Framing (Cambridge, UK: Cambridge University Press, 1996) 23-40).

Checkel, supra note 79 at $478-479$.

Elizabeth Boyle \& Sharon E. Preves, "National Politics as International Process: The Case of Anti-Female-Genital-Cutting Laws” (2000) 34:3 Law \& Society Review 703 at 715-721. 
that may support the conveyance of legal norms from one site of law to another: coercion, instrumental learning, cost-benefit adoption, mobilization, élite internalization, and acculturation. These causal mechanisms are expressed in generic terms that are sensitive to the pluralism of transnational legal processes, characterized as they may be by public, private, and hybrid forms of law and the multiple directions in which the conveyance of legal norms may operate - horizontally and vertically, from the top-down and the bottom-up, from, and to, multiple sites of law at different levels. ${ }^{111}$ In describing these mechanisms, I accordingly distinguish legal norms and actors based on whether they are "endogenous" (in that they are primarily affiliated with a given site of law) or "exogenous" (in that they originate outside this given site of law). ${ }^{112}$

As a result of the plurality of actors that may be involved in a given transnational legal process and the various strategies that they may pursue to support the transmission of legal norms across sites of law, transnational legal processes may feature the concurrent or sequential operation of numerous causal mechanisms of conveyance. ${ }^{113}$ Two factors underlie the importance of distinguishing between different causal mechanisms. First, as argued by Morin and Gold, these causal mechanisms may interact with one another in symbiotic ways to make the conveyance of legal norms more likely in a given case as well as across a population of cases over time. ${ }^{114}$ Second, these causal mechanisms may have differing implications for the enactment and implementation of exogenous legal norms. Many causal mechanisms of conveyance may result in an initial gap between how legal norms are formally enacted in a site of law and how they are implemented through actual changes in the practices of actors. ${ }^{115}$ The study of the transnational conveyance of legal norms thus requires paying attention to how interactions between causal mechanisms may, whether concurrently or sequentially, explain how and to what extent legal norms may be conveyed to, and eventually implemented in, a site of law. ${ }^{116}$

111 Goodman \& Jinks, supra note 72 at 27-28. $\quad 112 \quad$ Ibid at 28; Checkel, supra note 84 at 811.

113 See Lisa Vanhala, “The Diffusion of Disability Rights in Europe” (2015) 37:4 Human Rights Quarterly 831 (recognizing the role that structural as well agent-centered mechanisms may play in the diffusion of norms).

114 Morin \& Gold, supra note 63 at $783-785$.

115 Halliday \& Carruthers, supra note 62 at 406.

${ }_{116}$ Risse \& Ropp, supra note 99 at 13; Goodman \& Jinks, supra note 72 at 180-182. 


\section{The Causal Pathways of a Transnational Legal Process}

As is reflected in the various causal mechanisms discussed above, my analytical framework assumes that legal norms in a transnational legal process can operate both as "works-in-progress" that actors may construct together within sites of law as well as "fixed entities" whose meaning and effects remain relatively stable as they are conveyed from one site of law to another. ${ }^{117}$ Understanding that legal norms can be dynamic as well as static enables me to identify two broad types of causal pathways that a transnational legal process may follow.

In the first pathway shown in Figure I.1, a transnational legal process begins with the construction of legal norms in an initial site of law. The subsequent conveyance of legal norms from this site of law to another then functions as an "exogenous shock" $" 118$ that results in the enactment and implementation of exogenous legal norms. This pathway is consistent with accounts of legal transplantation and explains how transnational legal processes may result in the broad diffusion of legal norms and engender the convergence of law across multiple sites. ${ }^{119}$

In the second pathway illustrated in Figure I.2, the transnational legal process does not end with the initial conveyance of exogenous legal norms from one site of law to another. Instead, the conveyance of exogenous legal norms triggers the construction of hybrid legal norms, ${ }^{120}$ thereby reflecting the mediating influence of sites of law. ${ }^{121}$ There are several factors that can account for the potential of transnational legal processes to engender hybridity: the natural ambiguity of legal norms, ${ }^{122}$ the differing interests and norms

${ }^{117}$ Mona Lena Krook \& Jacqui True, "Rethinking the life cycles of international norms: The United Nations and the global promotion of gender equality" (2010) 18:1 European Journal of International Relations 103 at 106-110.

118 The notion that legal norms may serve as an "exogenous shock" is inspired by research on the internationalization of public policy. See Michael Howlett \& M. Ramesh, "The Policy Effects of Internationalization: A Subsystem Adjustment Analysis of Policy Change” (2002) 4:1 Journal of Comparative Policy Analysis 31.

119 Morin \& Gold, supra note 63; Miller, supra note 63.

120 See Sally Engle Merry, "Transnational Human Rights and Local Activism: Mapping the Middle" (2006) 108:1 American Anthropologist 38 at 44 (discussing the concept of hybridity as "a process that merges imported institutions and symbols with local ones, sometimes uneasily").

${ }_{121}$ Shaffer, supra note 62 at 26o; Goldbach, Brake \& Katzenstein, supra note 63 at 184; Brake \& Katzenstein, supra note 63 at 730 .

122 Krook \& True, supra note 117 at 109-110; Halliday \& Carruthers, supra note 62 at 18 . See generally Wayne Sandholtz \& Kendall Stiles, International Norms and Cycles of Change (Oxford, UK: Oxford University Press, 2009). 


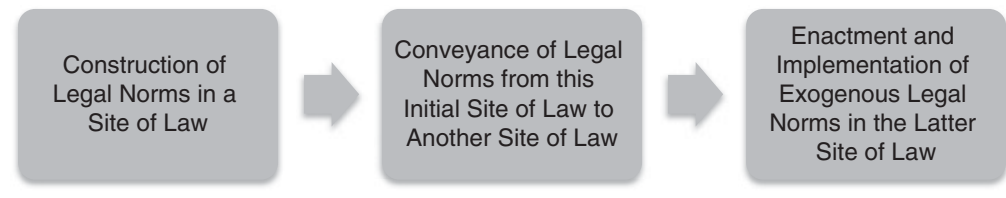

FIGURE I.1 The transplantation of legal norms through a transnational

legal process
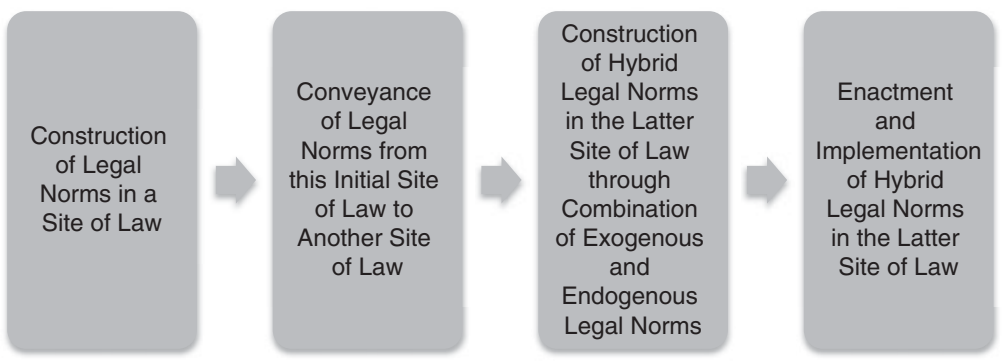

FIGURE I.2 The translation of legal norms through a transnational legal process

that may shape the engagement of actors in the construction and conveyance of legal norms, ${ }^{123}$ and the political struggles that the conveyance and translation of legal norms may trigger. ${ }^{124}$ This second pathway is antithetical to the notion that legal norms can be easily transplanted in a unidirectional manner from one site of law to another, ${ }^{125}$ without variations in their substance or effectiveness and without generating dynamic feedback effects. ${ }^{126}$ It is instead consistent with scholarship that focuses on the translation of legal norms ${ }^{127}$ and helps explain how the effects of transnational legal processes across sites of law may be heterogeneous. ${ }^{128}$ Given that many scholars view the construction

123 Shaffer, supra note 62 at 255-256; Halliday \& Carruthers, supra note 62 at 337-362.

124 Halliday \& Carruthers, supra note 62 at 1149-1152; Dezalay \& Garth, Dealing in Virtue, supra note 88 at $3-4$.

125 For the classic theory of "legal transplants," see Watson, supra note 63 at 98-114.

126 For a critique of Watson's theory of legal transplants, see Roger Cotterrell, Law, Culture and Society: Legal Ideas in the Mirror of Social Theory (Aldershot, UK: Ashgate Press, 2006) at 109116. On the challenges of transplantation and the ubiquity of translation, see Goldbach, Brake \& Katzenstein, supra note 63.

127 Goldbach, Brake \& Katzenstein, supra note 63 at 184 . Translation should be understood here as encompassing the construction of a hybrid legal norm through the causal mechanisms of cost-benefit commitment, persuasive argumentation, or both.

128 Ibid at 184 . Brake \& Katzenstein, supra note 63 at 730 ; See also Campbell, supra note 71 at 80 and 127; Finnemore \& Sikkink, supra note 72 at 893 . 
of hybrid legal norms as integral to the durability and effectiveness of exogenous legal norms in a site of law, ${ }^{129}$ this second pathway provides an important way of analyzing the impacts of transnational legal processes on the behavior of actors in the long-term.

The takeaway point here is that the causal mechanisms of the construction and conveyance of legal norms may interact with one another in a dynamic cycle that can yield a variety of different outcomes, at different stages, within a particular site of law. This view makes it possible to account for both the divergent and the convergent outcomes to which a transnational legal process may give rise as well as to develop complex causal pathways that can explain how transnational legal processes may emerge, evolve, and exert influence across one or more sites of law over time. ${ }^{130}$

\section{RESEARCH DESIGN}

My study of the construction and conveyance of the rights of Indigenous Peoples and local communities in the domain of REDD+ employs a research method known as "explaining-outcome process-tracing." ${ }^{131}$ Process-tracing is generally used for making within-case inferences about the role of causal mechanisms in the processes that link causes and outcomes. ${ }^{132}$ Explainingoutcome process-tracing specifically aims to trace the complex combination of systematic and nonsystematic causal mechanisms that produced a particular outcome in a single case. ${ }^{133}$ It tends to be characterized by theoretical eclecticism rather than parsimony. ${ }^{134}$ It "offers complex causal stories that incorporate different types of mechanisms as defined and used in diverse research

David Szablowski, Transnational Law and Local Struggles: Mining, Communities and the World Bank (Oxford, UK: Hart Publishing, 2007) at 13; Campbell, supra note 71 at 79-85. See generally Brake \& Katzenstein, supra note 63; Merry, supra note 120.

130 Two of the best known causal pathways that relate to the domestic influence of international norms are the ones specified by Koh (Koh, supra note 70 at 1409-1411) and by Risse, Ropp and Sikkink (Thomas Risse \& Kathryn Sikkink, "The Socialization of International Human Rights Norms into Domestic Politics: Introduction," in Thomas Risse, Stephen C. Ropp \& Kathryn Sikkink, eds., The Power of Human Rights: International Norms and Domestic Change (Cambridge, UK: Cambridge University Press, 1999) 1-38).

${ }^{131}$ Derek Beach \& Rasmus Brun Pedersen, Process-Tracing Methods: Foundations and Guidelines (Ann Arbor, Michigan: University of Michigan Press, 2013) at 18-21.

${ }^{132}$ Ibid at 1-4. See also Alexander George \& Andrew Bennett, Case Studies and Theory Development in the Social Sciences (Cambridge, MA: MIT Press, 2005) at 138 and 206 and Jeffrey T. Checkel, "Process Tracing" in Audie Klotz \& Deepa Prakash, eds., Qualitative Methods in International Relations. A Pluralist Guide (New York, NY: Palgrave Macmillan, 2008) 114 at 116 and 121.

133 Beach \& Pedersen, supra note 131 at $19 . \quad{ }^{134} \quad$ Ibid at 63-67. 
traditions" as well as "seeks to trace the problem-specific interactions among a wide range of mechanisms operating within or across different domains and levels of social reality." ${ }^{135}$ Process-tracing is especially appropriate for research that involves a particularly interesting or puzzling outcome that cannot be explained by existing theories. ${ }^{136}$

Rather than focus on the presence of dependent or independent variables, case selection in the context of process-tracing requires selecting cases that make it possible to trace the causal mechanisms that link one or more causes (X) to a particular outcome (Y). ${ }^{137}$ I selected Indonesia and Tanzania as two case studies for this book from among the more than sixty countries ${ }^{13^{8}}$ engaged in the pursuit of REDD+ on the basis of three criteria. First, both Indonesia and Tanzania have made significant progress in their jurisdictional REDD+ readiness activities, have been actively involved in the principal multilateral, bilateral, and nongovernmental initiatives for REDD+, and have hosted multiple REDD+ projects. ${ }^{139}$ Second, Indigenous and community rights were ultimately recognized or protected as part of the jurisdictional REDD+ laws, policies, and programs that these countries have adopted or the projectbased REDD+ activities that they have hosted, thus enabling me to study the causal mechanisms linking $\mathrm{X}$ and $\mathrm{Y}$. Third, given the historical resistance of the governments of Indonesia and Tanzania to the recognition and protection of these rights in other contexts, these two cases form the sort of "least-likely" case that is often the focus of in-depth qualitative research. ${ }^{140}$

Although I did not select these two countries based on comparative logic, they do differ in a number of ways. Indonesia is a middle-income country where the principal drivers of deforestation are expanding forestry, mining, and agricultural sectors that are integrated into global supply chains. The underlying causes of deforestation in Indonesia include the resource-driven economic policies of national and regional governments, growing international demand for commodities, and the high levels of collusion and corruption that encumber the effectiveness of the country's institutions and systems

135 Rudra Sil \& Peter J. Katzenstein, Beyond Paradigms: Analytical Eclectecism in the Study of World Politics (Basingstoke, UK: Palgrave MacMillan, 2010) at 419. See also George \& Bennett, supra note 132 at 215.

${ }_{136}$ Ibid. at $67-72$.

137 Beach \& Pedersen, supra note 131 at 146-154; Gary Goertz \& James Mahoney, A Tale of Two Cultures: Qualitative and Quantitative Research in the Social Sciences (Princeton, NJ: Princeton University Press, 2012) at 187-188.

${ }_{13} 8$ See Annex I. Overview of REDD+ activities in the developing world.

139 The REDD+ Desk, "REDD Countries," available at: http://theredddesk.org/countries (accessed 24 November 2014).

140 Audie Klotz, "Case Selection" in Klotz \& Prakash, supra note 132, 43 at 52. 
of forest governance. ${ }^{141}$ By contrast, Tanzania is a least-developed country in which forests and their resources support the livelihoods of rural communities. The main drivers of deforestation in Tanzania are thus local in nature, and most notably include the conversion and use of forests for subsistence-based agriculture, livestock grazing, firewood and charcoal production, and smallscale logging. ${ }^{12}$ Furthermore, whereas the governance of forests in Indonesia remains highly centralized and gives rise to frequent disputes between governments and local communities over the recognition of local forest tenure, resource rights, and institutions, ${ }^{143}$ Tanzania has developed one of the most favorable policy environments for the pursuit of community forestry in Africa. ${ }^{144}$ As I explain in Chapter 6, these differences are relevant to understanding the scope conditions of the causal mechanisms that explain whether, how, and to what effect actors may construct and convey Indigenous and community rights in the context of REDD+ activities in a developing country.

I employed multiple methods and sources of data collection to operationalize the explaining-outcome process-tracing for this book. ${ }^{145}$ First, I analyzed the ninety-four semi-structured élite interviews that I conducted with individuals affiliated with international organizations, developing and developed country governments, corporations, and NGOs actively working on REDD+ around the world. ${ }^{146}$ Second, I drew on the observations I gathered through my participation as a civil society delegate and legal expert in multiple legal and policy processes relating to REDD+ from 2007 to $2014 .{ }^{147}$ This participationobservation across multiple sites over time enabled me to get a better sense of the evolving views of different actors with respect to REDD+ and its

${ }^{141}$ Mairon Bastos Lima, Joyeeta Gupta, Nicolien van der Grijp \& Fahmuddin Agus, "Case Study: Indonesia" in Joyeeta Gupta, Nicolien van der Grijp \& Onno Kuik, eds., Climate Change, Forests and REDD: Lessons for Institutional Design (Abingdon, UK: Routledge, 2013) 121 at 122-124.

142 Neil D. Burgess et al., "Getting ready for REDD+ in Tanzania: A case study of progress and challenges" (2010) 44:3 Oryx 339 at 341.

143 Lima et al., supra note 141 at $125^{-133}$.

144 See Tom Blomley \& Said Iddi, "Participatory Forest Management: 1993-2009: Lessons learned and experiences to date" (United Republic of Tanzania, Ministry of Natural Resources and Tourism, Forestry and Beekeeping Division, 2009), available at: www.tzon line.org/pdf/participatoryforestmanagement2009.pdf (accessed 8 October 2014).

145 For a complete overview of my approach to the collection and analysis of data, including a list of interviews and sites, see Sébastien Jodoin, "On-Line Appendix on REDD+ Fieldwork," (March 2015), available at: www.sjodoin.ca/data (accessed 12 March 2015).

146 On the concept of élite interviews and their role in process-tracing, see Oisín Tansey, "Process Tracing and Elite Interviewing: A Case for Non-probability Sampling” (2007) 40(4) PS: Political Science \& Politics 765 .

147 See Jodoin, supra note 145. 
implications for rights. ${ }^{14^{8}}$ Third, I analyzed the extensive collection of laws, policies, reports, contracts, and other documentation relevant to REDD+ produced by international organizations, developing and developed country governments, corporations, and NGOs that I gathered during my fieldwork. Fourth, I drew on the emails that I exchanged with several of my interviewees and other sources to obtain documents as well as clarify points of information throughout my fieldwork and the process of drafting my dissertation. Fifth, I relied on the secondary literature that has been produced by scholars on REDD+ and more broadly on the international organizations, developing and developed country governments, corporations, and NGOs that have played a key role in its development and implementation. Sixth and finally, I built an original data set on the implications of 38 REDD+ projects for the rights of Indigenous Peoples and local communities in Indonesia and Tanzania. ${ }^{149}$ By triangulating across these different sources of data ${ }^{150}$ and carefully assessing their reliability, ${ }^{151}$ I was able to trace the role of different causal mechanisms in the construction and conveyance of Indigenous and community rights in the transnational legal process for REDD+ in my two case study countries.

\section{ORIGINALITY AND SIGNIFICANCE}

The original analysis and findings in this book make several contributions to the existing literature. First and foremost, this book contributes to literature examining the implications that REDD+ activities may hold for the rights of Indigenous Peoples and local communities in developing countries. Much of the existing scholarship on REDD+ and rights is replete with theoretically plausible, yet no less speculative, claims and arguments about the effects of REDD+ on Indigenous and community rights. The little empirical research that does exist on this topic has focused on the processes and outcomes

${ }^{148}$ On the utility of participation/observation, see Hugh Gusterson, "Ethnographic Research" in Klotz \& Prakash, supra note 132, 93 at 99-103. See also Kathleen M. DeWalt \& Billie R. DeWalt. Participant observation: a guide for fieldworkers (Walnut Creek, CA: AltaMira Press, 2002) at 92.

149 This data set was developed through the collection and independent coding of the design documents of projects, third-party evaluations of their impacts and outcomes, and secondary sources retrieved online. For a complete overview of my approach to the collection and analysis of project data, including a list of projects, see Sébastien Jodoin \& Kathryn Hansen, "On-Line Appendix on the Implications of REDD+ Projects for Indigenous and Community Rights in Indonesia and Tanzania" (June 2016), available at: www.sjodoin.ca/data (accessed 16 June 2016).

150 Checkel, supra note 132 at 119. $\quad{ }^{151} \quad$ Beach \& Pedersen, supra note 131 at 120-143. 
associated with REDD+ projects implemented at the local level, ${ }^{152}$ leaving the question of how rights have been considered within the context of jurisdictional REDD+ activities at the national level largely unexplored. Given the advanced stage that REDD+ has reached around the world, I have been able to undertake novel empirical research and analysis to understand how and to what effect the rights of Indigenous Peoples and local communities have been constructed and conveyed at national and local levels.

Many scholars hypothesize that REDD+ outcomes are being driven by entrenched power asymmetries in forest governance that new interventions or instruments like REDD+ are incapable of changing and may, worse still, exacerbate. ${ }^{153}$ With a view to capturing the ways in which law may offer limited, yet no less potent, support for change in transnational contexts, ${ }^{154}$ I have sought to understand the risks as well as the opportunities that REDD+ offers for the recognition and protection of the rights of Indigenous Peoples and local communities in developing countries. On the whole, I argue that the pursuit of REDD+ has functioned as something of an exogenous shock disrupting the traditional patterns of the development and implementation of legal norms relating to the rights of Indigenous Peoples and local communities in Indonesia and Tanzania. My findings demonstrate that jurisdictional and project-based REDD+ activities have, through different causal pathways, provided meaningful opportunities for developing and developed country governments, international organizations, Indigenous Peoples, local communities, NGOs, and even private firms to convey, from above and from below, these rights to national and local sites of law. For instance, both the Indonesian and Tanzanian governments have, for the first time, recognized rights such as the right to free, prior, and informed consent in the context of their national REDD+ policy processes. These developments have not taken place in a vacuum and have been facilitated by broader developments relating to the global emergence of Indigenous rights, the growing relevance of human rights to the fields of climate change and forest conservation, and ongoing processes of democratization in Indonesia and Tanzania.

At the same time, my findings do not suggest that REDD+ has functioned as a panacea either. Across Indonesia and Tanzania, the transnational legal process for REDD+ has resulted in the translation of new hybrid legal norms that reflect the resilience and mediating influence of national legal systems

152 See, e.g., Duchelle et al., supra note 46; Corbera et al., supra note 47; Sunderlin et al., supra note 47; Mustalahti et al., supra note 57; Pablo Reed, supra note 57; Leggett \& Lovell, supra note 57 .

153 See, e.g., Ribot \& Larson, supra note 13 at 236. 154 Merry, supra note 15. 
and politics. Traditional resistance against the concept of Indigenous Peoples has meant that their rights have either been recognized alongside the rights of forest-dependent communities (as has been the case in Indonesia) or that they have been translated as applying to forest-dependent communities only (as has been the case in Tanzania). Moreover, the recognition and implementation of the participatory rights of Indigenous Peoples and local communities (such as rights to full and effective participation or to free, prior, and informed consent) has been relatively more effectual than the recognition and implementation of their substantive rights (such as rights to forests, land tenure, and resources, or livelihoods). These disparities in outcomes give some credence to the expectations of scholars regarding the limitations of REDD+ for the promotion of the rights of Indigenous Peoples and local communities.

By answering important questions about the construction and conveyance of Indigenous and community rights in the context of REDD+, this book also makes a timely and important contribution to an emerging body of knowledge on the law and governance of REDD+. ${ }^{155}$ Indeed, understanding how the pursuit of REDD+ has been and can be reconciled with important social objectives such as the protection of human rights speaks to larger debates about the objectives, challenges, opportunities, effectiveness, and prospects of REDD $+{ }^{156}$ Rather than argue that there is an inherent trade-off between the broader effectiveness of REDD+ and the protection of human rights, my research suggests that the underlying ineffectiveness of REDD+ as an instrument has provided unexpected opportunities for the recognition and protection of the rights of Indigenous Peoples and local communities in developing countries.

Lastly, as one of the first major empirical studies of a transnational legal process to build on the recent work of Shaffer and Halliday, ${ }^{157}$ this book contributes to the socio-legal study of law in a number of ways. To begin with, my research confirms the methodological importance of adopting a legal pluralist perspective for the study of transnational legal processes. Legal

155 Lyster, MacKenzie \& McDermott, supra note 11; Voigt, supra note 17; Visseren-Hamakers, Ingrid et al., "Interdisciplinary perspectives on REDD+ Editorial overview" (2012) 4 Current Opinion in Environmental Sustainability 1; Peter J. Kanowski, Constance L. McDermott \& Benjamin Cashore, "Implementing REDD+: lessons from analysis of forest governance" (2010) 14:2 Environmental Science \& Policy 111-117; Simon Butt, Rosemary Lyster \& Tim Stephens, eds., Climate Change and Forest Governance: Lessons from Indonesia (Abingdon, UK: Routledge, 2015).

156 Schroeder \& McDermott, supra note 11.

157 Shaffer, supra note 62; Halliday \& Shaffer, supra note 62. 
pluralism is critical for uncovering whether and how public and private actors may construct and convey legal norms within a complex transnational legal process like REDD+ that emanates from the intersections of two transnational regime complexes (one for climate change, ${ }^{158}$ the other for forestry) ${ }^{159}$ and features a multiplicity of forms, sites, and levels of normativity. Moreover, this book illustrates the value of understanding a transnational legal process as a cycle that moves back and forth between the construction and conveyance of legal norms, having the potential to yield homogeneous as well as heterogeneous outcomes across sites of law. Whereas there tends to be a bias in favor of finding evidence for the diffusion of norms in much of the political science literature, ${ }^{160}$ my careful study of the interpretation and application of the status and rights of Indigenous Peoples across multiple sites of law reveals that transnational legal processes may, among other outcomes, lead to the translation of legal norms rather than their transplantation or may fail to engender their transmission altogether. Finally, this book illustrates the utility of identifying and studying the various causal mechanisms that drive the construction and conveyance of legal norms to produce a complex and theoretically eclectic account of a transnational legal process. By developing an analytical framework that builds bridges between political science and socio-legal studies and rigorously employing process-tracing to draw causal inferences about the nature and influence of legal norms in a transnational context, it offers a number of important methodological lessons for the study of legal phenomena in a globalizing world. ${ }^{161}$

\section{OVERVIEW}

The book proceeds as follows. In Chapter 1, I provide an overview of the transnational legal process for REDD+. I begin by presenting the origins and scope of the transnational legal process for REDD+. I then identify the multiplicity of sites of law through which it has evolved at the international, transnational, national, and local levels. I conclude by discussing the increasingly complex character of the transnational legal process for REDD+ and,

${ }_{158}$ Kenneth W. Abbott, "The Transnational Regime Complex for Climate Change" (2012) 30 Environment and Planning C: Government and Policy 571; Liliana B. Andonova, Michele M. Betsill \& Harriet Bulkeley, "Transnational Climate Governance" (2009) 9:2 Global Environmental Politics 52.

159 Jeremy Rayner, Alexander Buck \& Pia Katila, eds., Embracing Complexity: Meeting the Challenges of International Forest Governance (Vienna, Austria, 2010).

160 For more on this critique, see Vanhala, supra note 113 at $838-839$.

${ }_{161}$ On the need for additional empirical research on transnational legal processes, see Shaffer, supra note 62 . 
most notably, by outlining the different pathways that exist for the conveyance of legal norms to developing countries participating in or hosting REDD+ activities.

In Chapter 2, I examine how the rights of Indigenous Peoples and local communities have been addressed by some of the most influential international and transnational sites of law for REDD+. To begin with, I describe how human rights issues first emerged in the transnational legal process for REDD+. Next, I analyze the recognition of Indigenous and community rights in the context of the UNFCCC; the two leading multilateral programs for REDD+ (the World Bank Forest Climate Partnership Facility and the UN-REDD Programme); a multi-stakeholder safeguards initiative for jurisdictional REDD+ (the REDD+ SES); and a leading nongovernmental certification program for project-based REDD+ (the Climate, Community \& Biodiversity Alliance (CCBA)). I conclude by highlighting some of the key differences that have emerged in relation to rights-related issues across these different sites of law.

In Chapters 3 and 4 , I trace the conveyance and construction of the rights of Indigenous Peoples and local communities through the implementation of jurisdictional REDD+ activities in Indonesia and Tanzania. I begin by reviewing the broader context in which jurisdictional REDD+ activities have been pursued in these countries, discussing the nature and importance of forests, the principal drivers of deforestation, the role of local communities in forest governance, and the status and rights of Indigenous Peoples. I then describe the history and governance of the jurisdictional REDD+ readiness phase in both countries, outlining the roles played by various domestic and international actors in its design and implementation. Next, I provide an account and explanation of the conveyance and construction of legal norms relating to the rights of Indigenous Peoples and local communities in the context of the development of their national strategies and safeguard policies for REDD+. I conclude by reflecting on the outcomes of the pursuit of jurisdictional REDD+ in Indonesia and Tanzania and their implications for the recognition and protection of the rights of Indigenous Peoples and local communities in the long-term.

In Chapter 5, I analyze the conveyance and construction of legal norms relating to the rights of Indigenous Peoples and local communities in the context of project-based REDD+ activities implemented at the local level. I begin by providing an overview of the nature, scale, and operation of the transnational market for project-based REDD+. I then examine how the rights of Indigenous Peoples and local communities have been recognized and protected through the pursuit of project-based REDD+ activities in 
Indonesia and Tanzania. Next, I offer an explanation of the conveyance and construction of these rights within REDD+ projects implemented in both countries. I conclude by reflecting on the broad outcomes of the pursuit of project-based REDD+ activities and their implications for the recognition and protection of the rights of Indigenous Peoples and local communities in the long-term within the carbon market.

In Chapter 6, I compare the conveyance and construction of rights through REDD+ activities developed and implemented in Indonesia and Tanzania. Although I did not select these two countries on the basis of variations in initial conditions or eventual outcomes relevant to the recognition and protection of rights, a number of lessons can nonetheless be drawn from a comparison of experiences across sites and levels of law in these two countries. I begin by discussing findings that relate to rights in the context of the pursuit of jurisdictional REDD+ activities at the national level, before turning to the development and implementation of project-based REDD+ activities at the local level. I conclude with a global comparison of the intersections between rights and various REDD+ activities in these two countries, and highlight the mediating influence of national laws and politics in the pursuit of REDD+ at various levels.

In the concluding chapter, I build on my research findings in three ways. I begin by reviewing and discussing the main findings from this book that pertain to the complex relationship between the transnational legal process for REDD+ and the rights of Indigenous Peoples and local communities. Next, I identify the questions and implications that my findings raise for scholarship on REDD+ as well as the nature and influence of transnational legal processes. I conclude by addressing the implications of this book for practitioners and activists working to build synergies between the pursuit of REDD+ and the promotion of human rights. 


\section{The Transnational Legal Process for REDD+}

\subsection{THE ORIGINS OF THE TRANSNATIONAL LEGAL PROCESS FOR REDD+}

In the first half of the 2000s, numerous developing countries, NGOs, and scientists pressed for the elaboration of mechanisms within the UNFCCC to tackle carbon emissions from forestry-related sources in developing countries. ${ }^{162}$ While atmospheric and climate scientists had long recognized the importance of reducing these sources of carbon emissions in developing countries, ${ }^{163}$ they had only been addressed in a limited manner due to political concerns that climate mitigation action should focus on industrialized sources of carbon emissions. ${ }^{164}$ In particular, the rules adopted for the clean development mechanism $(\mathrm{CDM})$ under the Kyoto Protocol $^{165}$ specifically excluded from its purview projects aiming to reduce carbon emissions through the avoidance of deforestation. ${ }^{166}$ Nonetheless, the first generation of forest carbon projects pursued through the CDM and private carbon markets laid the technical groundwork and built momentum for future efforts aimed at addressing carbon emissions in developing country forests in global climate governance. ${ }^{167}$

162 Sébastien Jodoin \& Sarah Mason-Case, "What Difference Does CBDR Make? A Socio-Legal Analysis of the Role of Differentiation in the Transnational Legal Process for REDD+" (2016) 5(2) Transnational Environmental Law 255.

163 William Boyd, "Ways of Seeing in Environmental Law: How Deforestation Became an Object of Climate Governance" (2010) 37 Ecology Law Quarterly 843 at 880-891.

164 Ibid. at $869-870$.

165 Kyoto Protocol to the United Nations Framework Convention on Climate Change, 10 Dec. 1997, 37 ILM 22 (1998), UN Doc. FCCC/CP/1997/7/Add.1, entered into force 16 Feb. 2005. Bernhard Schlamadinger et al., "A Synopsis of Land Use, Land-Use Change and Forestry (LULUCF) under the Kyoto Protocol and Marrakech Accords" (2007) 10:4 Environmental Science E Policy 271 at $278-279$.

167 Emily Boyd, Esteve Corbera \& Manuel Estrada, "UNFCCC Negotiations (pre-Kyoto to COP-9): What the Process Says about the Politics of CDM-sinks" (2008) 8 International Environmental Agreements 95 at 108-109. 
In December 2005, the governments of Costa Rica and Papua New Guinea, on behalf of the Coalition of Rainforest Nations, proposed that the UNFCCC COP consider developing new mechanisms to reduce emissions from deforestation (RED) in developing countries. ${ }^{168}$ As part of the Bali Action Plan adopted in December 2007, the UNFCCC COP launched international negotiations for the development of "policy approaches and positive incentives on issues related to reducing emissions from deforestation and forest degradation in developing countries; and the role of conservation, sustainable management of forests and enhancement of forest carbon stocks in developing countries." 169 In a separate decision focusing specifically on "approaches to stimulate action" on REDD,$+{ }^{170}$ the UNFCCC COP affirmed the "urgent need to take meaningful action" to reduce GHG emissions from forest-based sources in developing countries and recognized that doing so could "promote co-benefits" and "complement the aims and objectives of other relevant international conventions and agreements." ${ }^{171}$

The concept of REDD+ elicited strong support among a wide coalition of public and private actors from both the North and the South who were variously concerned with climate change, forest governance, and sustainable development. ${ }^{172}$ At the time, REDD+ was supported as a win-win-win solution that could not only reduce an estimated 17 percent of global carbon emissions worldwide, ${ }^{173}$ but could also protect forests and their critical ecosystems and help alleviate poverty among forest-dependent and rural communities. ${ }^{174}$

See Submission by the Governments of Papua New Guinea \& Costa Rica, "Reducing Emissions from Deforestation in Developing Countries: Approaches to Stimulate Action" Eleventh Conference of the Parties to the UNFCCC: Agenda Item 6, available at: http:// unfccc.int/resource/docs/2005/cop11/eng/misco1.pdf (accessed 21 May 2014).

169 Decision 1/CP.13, "Bali Action Plan," Report of the Conference of the Parties on its thirteenth session, Part Two: Action taken by the Conference of the Parties, UN Doc. FCCC/CP/2007/ 6/Add.1 (14 March 2008) para. 1(b)(ii). See Till Pistorius, "From RED to REDD+: The Evolution of a Forest-Based Mitigation Approach for Developing Countries” (2012) 4:6 Current Opinion in Environmental Sustainability 638; Jan Willem den Besten, Bas Arts \& Patrick Verkooijen, “The Evolution of REDD+: An Analysis of Discursive-Institutional Dynamics" (2014) 35 Environmental Science \& Policy 40.

170 Decision 2/CP.13, "Reducing Emissions from Deforestation in Developing Countries: Approaches to Stimulate Action" in Report of the Conference of the Parties on its Thirteenth Session, Part Two: Action Taken by the Conference of the Parties at its Thirteenth Session, UN Doc. FCCC/CP/2007/6/Add.1 (14 March 2008).

${ }^{171}$ Ibid., preamble. $\quad{ }^{172}$ McDermott, Levin \& Cashore, supra note 5.

173 Arild Angelsen \& Desmond McNeill, "The Evolution of REDD+" in Arild Angelsen et al., eds., Analysing REDD+. Challenges and Choices (Bogor Barat, Indonesia: CIFOR, 2012) 31 at 35 .

174 Marleen Buizer, David Humphreys \& Wil de Jong, "Climate Change And Deforestation: The Evolution Of An Intersecting Policy Domain” (2013) 35 Environmental Science \& Policy 1. 
Within the UNFCCC, negotiations on REDD+ progressed at a remarkable pace, especially when compared with the broader set of international negotiations on climate change. ${ }^{175}$ In December 2010, the UNFCCC COP adopted the Cancun Agreements, in which it defined the scope of jurisdictional REDD + activities and established the stages and requirements for their implementation in developing countries. ${ }^{176}$ The UNFCCC COP has since adopted a series of decisions further clarifying the rules for the pursuit of jurisdictional REDD+ in developing countries, ${ }^{177}$ culminating in the integration of jurisdictional REDD+ in the Paris Agreement adopted in December 2015. ${ }^{178}$ These rules are summarized in Table 1.1.

In the Bali Action Plan as well as the Cancun Agreements, the UNFCCC $\mathrm{COP}$ encouraged developing countries to take voluntary measures to prepare for domestic operationalization of jurisdictional REDD+ and called on developed countries, international organizations, and NGOs to provide finance, capacity-building, and technical assistance to support them in their efforts. ${ }^{179}$ In response, an array of developing and developed country governments, international organizations, multilateral development banks, conservation and development NGOs, and corporations have supported the development and implementation of REDD+ activities around the world. They have most notably established knowledge-sharing, capacity-building, and technical assistance programs, mobilized finance, carried out research and analysis, developed rules and guidance, created certification programs, standards, and methodologies, and organized countless policy meetings, networks, and dialogues. on long-term Cooperative Action under the Convention” in Report of the Conference of the Parties on its sixteenth session, Part Two: Action taken by the Conference of the Parties, UN Doc. FCCC/CP/2010/7/Add.1 (15 March 2011) at paras 68-79.

177 Decision 2/CP.17, Outcome of the work of the Ad Hoc Working Group on Long-term Cooperative Action under the Convention, in Report of the Conference of the Parties on its sixteenth session, Part Two: Action taken by the Conference of the Parties, UN Doc. FCCC/ CP/2011/9/Add.1 (15 March 2012) at paras 63-73; Decisions 9/CP.19, 10/CP.19, 11/CP.19, 12/ CP.19, 13/CP.19, 14/CP.19 and 15/CP.19, in Report of the Conference of the Parties on its nineteenth session, held in Warsaw from 11 to 23 November 2013 , UN Doc. FCCC/CP/2013/ 10/Add.1 (31 January 2014); Decisions 16/CP.21, 17/CP.21 and 18/CP.21, in Report of the Conference of the Parties on its twenty-first session, held in Paris from 30 November to 13 December 2015, Part Two: Action taken by the Conference of the Parties, UN Doc. FCCC/ CP/2015/10/Add.3 (29 January 2016).

${ }_{178}$ Decision 1/CP.21, Adoption of the Paris Agreement, in Report of the Conference of the Parties on its twenty-first session, held in Paris from 30 November to 13 December 2015, UN Doc. FCCC/CP/2015/10/Add.1 (29 January 2016) at article 5(2). 
TABLE 1.1. The elements of jurisdictional REDD+ under the UNFCCC ${ }^{180}$

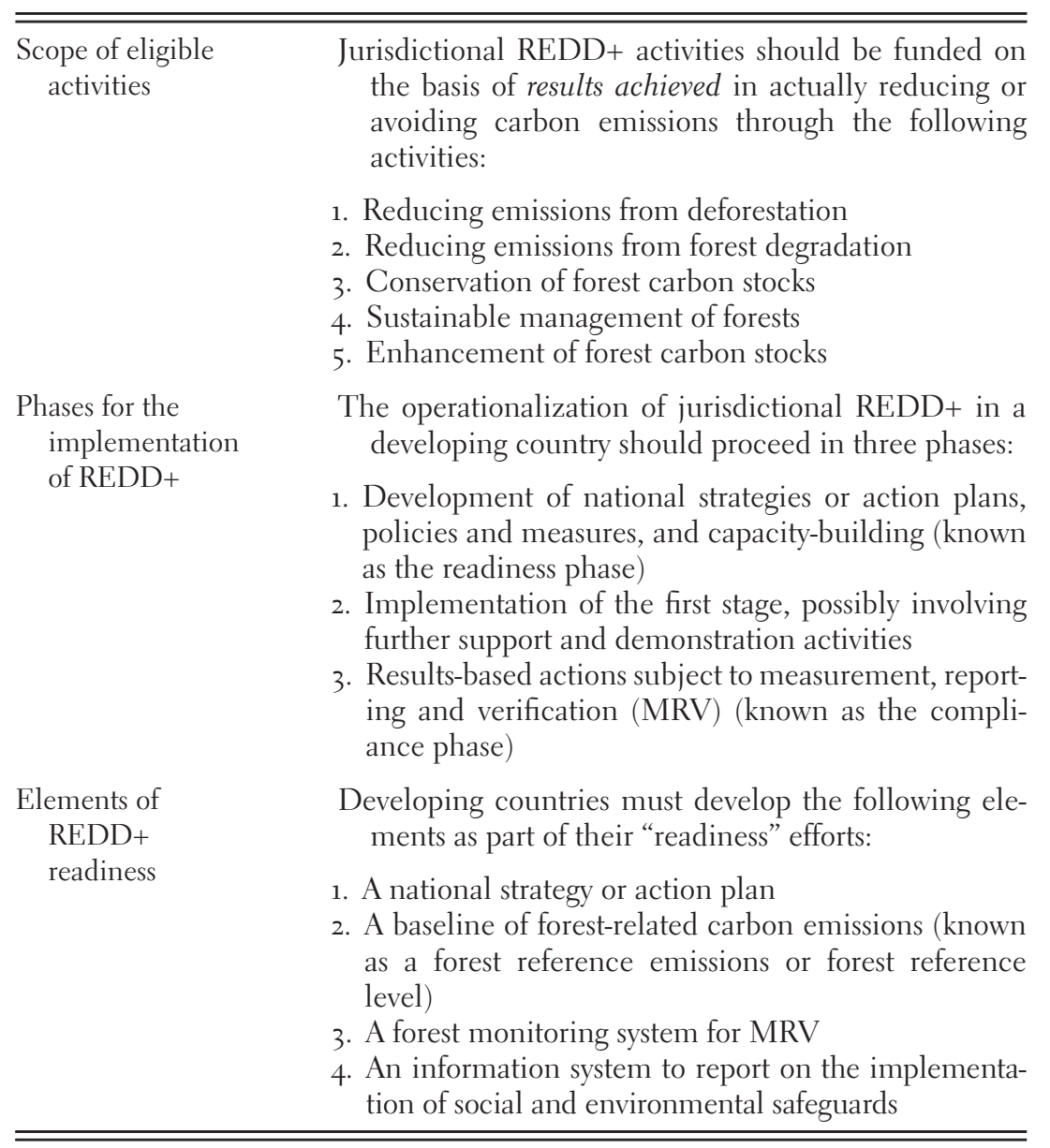

Although these initiatives differ in many respects, they each adhere to the three basic ideas that have come to define the wide range of REDD+ programs, policies, and projects around the world. First, REDD+ initiatives aim to increase carbon sequestration in developing country forests by funding activities that either reduce "negative changes" or enhance "positive changes" in forest carbon stocks. ${ }^{181}$ Second, they are intended to finance

180 UNFCCC COP, Decision 2/CP.13 at paras. 1-3, 5, and 9; UNFCCC COP, Decision 1/CP.16 at paras. 71,74 , and 76 .

${ }^{181}$ Sheila Wertz-Kanounnikoff \& Arild Angelsen, "Global and National REDD+ Architecture Linking Institutions and Actions" in Arild Angelsen, ed., Realising REDD+: National Strategy and Policy Options (Bogor, Indonesia: CIFOR, 2009) 13 at 16-17. 
activities on the basis of results achieved in reducing or avoiding carbon emissions or increasing carbon stocks that are measured, reported, and verified (MRV) on the basis of a pre-existing baseline or reference level. ${ }^{182}$ Third, they are meant to take into account other important social or environmental objectives and considerations beyond carbon sequestration by requiring that activities comply with a set of social and environmental safeguards or that they deliver co-benefits such as the reduction of poverty or the preservation of biodiversity. ${ }^{183}$

Beyond these three core ideas, there is significant diversity in the ways in which legal norms for REDD+ have been developed and applied by public and private actors around the world. ${ }^{184}$ The most important area of divergence in the transnational legal process for REDD+ relates to the difference between jurisdictional and project-based activities. Jurisdictional REDD+ refers to programs implemented by developing countries that seek to reduce carbon emissions from forest-based sources at a national scale in line with the requirements set by the UNFCCC COP. In contrast, project-based REDD+ generally consists of activities implemented by corporations, NGOs, and communities to reduce forest carbon emissions at the local level. These activities must follow the methodologies and meet the standards established by nongovernmental certification programs in order to generate credits that can be sold and traded on carbon markets. ${ }^{185}$ Some REDD+ projects have been implemented by governments or their partners to experiment with new tools and methodologies as part of their jurisdictional readiness efforts at the national or subnational level. Most REDD+ projects have been carried out by NGOs, corporations, or communities, with the aim of sequestering carbon as well as possibly delivering other social and environmental benefits, in order to generate carbon credits that can be sold or traded on voluntary carbon markets. ${ }^{186}$ While the pursuit of project-based REDD+ activities can be affected by as well as feed into jurisdictional REDD+ programs implemented

${ }_{182}$ Martin Herold \& Margaret M. Skutsch, "Measurement, Reporting and Verification for REDD+: Objectives, Capacities and Institutions” in ibid., 85.

${ }_{183}$ Anthony Hall, Forests and Climate Change: The Social Dimensions of REDD in Latin America (Cheltenham, UK: Edward Elgar, 2012) at 122-143.

${ }_{184}$ McDermott et al., "Operationalizing Social Safeguards," supra note 54 at 65.

185 Eduard Merger, Margaret Dutschke \& Louis Verchot, "Options for REDD+ Voluntary Certification to Ensure Net GHG Benefits, Poverty Alleviation, Sustainable Management of Forests and Biodiversity Conservation" (2011) 2 Forests 550.

186 Erin Sills, Erin Myers Madeira, William D. Sunderlin, \& Sheila Wertz-Kanounnikoff, "The Evolving Landscape of REDD+ Projects" in Angelsen, supra note 4, 265. 
at the national level, these two forms of REDD+ are fundamentally different and are ultimately governed by different sites of law.

\subsection{LEVELS, SITES, AND FORMS OF LAW IN THE TRANSNATIONAL}

\section{LEGAL PROCESS FOR REDD+}

While the UNFCCC has played an important role in the construction of an initial set of legal norms for REDD+, the proliferation of multilateral, bilateral, and nongovernmental initiatives has meant that the transnational legal process for REDD+ has become increasingly plural over time. ${ }^{187}$ As is summarized in Table 1.2, a heterogeneous array of public and private actors has engaged in the construction and conveyance of legal norms for REDD+ within and across multiple sites and forms of law that encompass as well as transcend the decision-making of the UNFCCC. ${ }^{188}$ The transnational legal process for REDD+ has become all the more multi-layered because it has evolved at the intersections of two broader domains that also exhibit significant poly-centricity, one being climate change, ${ }^{189}$ the other forestry. ${ }^{190}$

At the international level, two of the most influential multilateral initiatives established for REDD+ have been the World Bank Forest Carbon Partnership Facility (FCPF) and the UN-REDD Programme. Launched at the 13th session of the UNCCC in December 2007 and operational since June 2008, the FCPF is comprised of two funds for which the World Bank serves as trustee and provides a secretariat: a Readiness Fund that supports developing country capacity-building and preparedness for REDD+ activities and a Carbon Fund that tests eventual performance-based payments for emissions reductions generated through REDD+ activities. ${ }^{191}$ In addition, the FCPF aims to disseminate the tools and knowledge developed as a result of its support for REDD+ readiness and emissions reductions. ${ }^{192}$ The UN-REDD Programme

187 Frances Seymour \& Arild Angelsen, "Summary and Conclusions REDD+ without Regrets" in Angelsen et al., supra note 4, 317 at 319.

188 See Harro van Asselt and Constance L. McDermott, "The Institutional Complex for REDD+: a 'Benevolent Jigsaw'?" in Voigt, supra note 17, 63.

189 See, e.g., Abbott, supra note 158. $190 \quad$ See, e.g., Rayner, Buck \& Katila, supra note 159.

${ }_{191}$ The FCPF has 47 partner countries in Africa, Asia, Latin America, and the Caribbean as well as 17 developed-country, private-sector, and NGO donors, and approximately 1.057 billion US dollars have been pledged to the trust funds under its management. FCPF, "About FCPF" available at: www.forestcarbonpartnership.org/about-fcpf-o (accessed 5 May 2016).

192 International Bank for Reconstruction and Development, Charter Establishing the Forest Carbon Partnership Facility (8 August 2013), available at: www.forestcarbonpartnership.org/ sites/fcp/files/2013/August2013/FCPF\%20Charter\%20-\%208-8-13\%2oclean.pdf (accessed 30 December 2013) at Section 2.1 [FCPF Charter $]$. 
TABLE 1.2. Levels, sites, and forms of law in the transnational legal process for REDD+

\begin{tabular}{|c|c|c|}
\hline Levels of law & Sites of law & Forms of law \\
\hline $\begin{array}{l}\text { International } \\
\text { sites }\end{array}$ & $\begin{array}{l}\text { Multilateral environmental } \\
\text { agreements and } \\
\text { negotiations (UNFCCC). } \\
\text { Multilateral programs } \\
\text { (World Bank Forest } \\
\text { Carbon Partnership } \\
\text { Facility and the } \\
\text { UN-REDD Program). } \\
\text { Bilateral programs (NICFI). }\end{array}$ & $\begin{array}{l}\text { Decisions of the UNFCCC COP. } \\
\text { Instruments and agreements adopted } \\
\text { within international organizations. } \\
\text { Conditions and rules for accessing } \\
\text { funding. } \\
\text { Operational safeguards. } \\
\text { Guidance materials and methodologies. } \\
\text { Laws and policies governing bilateral } \\
\text { programs. } \\
\text { Bilateral agreements. }\end{array}$ \\
\hline $\begin{array}{l}\text { Transnational } \\
\text { sites }\end{array}$ & $\begin{array}{l}\text { Nongovernmental } \\
\text { certification programs } \\
\text { (VCS; CCBA). }\end{array}$ & $\begin{array}{l}\text { Certification standards and rules. } \\
\text { Guidance materials and } \\
\text { methodologies. }\end{array}$ \\
\hline National sites & $\begin{array}{l}\text { Developing countries } \\
\text { participating in the } \\
\text { operationalization of } \\
\text { REDD+. }\end{array}$ & $\begin{array}{l}\text { REDD+ laws, regulations, and } \\
\text { policies. } \\
\text { REDD+ strategies. }\end{array}$ \\
\hline $\begin{array}{l}\text { Subnational } \\
\text { sites }\end{array}$ & $\begin{array}{l}\text { REDD+ readiness activities in } \\
\text { subnational jurisdictions. } \\
\text { REDD+ market-based } \\
\text { projects. }\end{array}$ & $\begin{array}{l}\text { REDD+ laws, regulations, and policies. } \\
\text { REDD+ strategies. } \\
\text { Project design documents. } \\
\text { Contracts and protocols with local } \\
\text { communities. } \\
\text { Licenses from local authorities. } \\
\text { Carbon sale agreements. }\end{array}$ \\
\hline
\end{tabular}

is a collaborative initiative jointly established in June 2008 by the United Nations Development Programme (UNDP), the United Nations Environment Programme (UNEP), and the Food and Agriculture Organization (FAO). ${ }^{193}$ It provides direct support and technical assistance to developing countries carrying out national REDD+ readiness efforts and seeks to generate and disseminate knowledge, methodologies, tools, and approaches for the development of REDD+ at a global level. ${ }^{194}$ These initiatives have generated legal

193 FAO, UNDP \& UNEP, UN Collaborative Programme on Reducing Emissions from Deforestation and Forest Degradation in Developing Countries Framework Document (20 June 2008), available at: www.un-redd.org/Portals/15/documents/publications/UN-REDD_Fr ameworkDocument.pdf (accessed 30 December 2013) [UN-REDD Framework Document].

194 As of June 2016, more than 281 million US dollars have been committed to the UN-REDD Programme, which currently supports national REDD+ readiness programs in 64 partner 
norms for REDD+ that have taken on various forms, most notably including the agreements that led to their creation, ${ }^{195}$ the rules and conditions they set for accessing funding for REDD+ activities, ${ }^{196}$ the operational safeguards that exist for the delivery of activities they finance, ${ }^{197}$ and the guidance documents they have developed for the implementation of REDD+ activities. ${ }^{198}$

A number of developed country governments have also established bilateral programs to support the implementation of REDD+ around the world. The most important among these is the Norwegian International Climate and Forest Initiative (NICFI) launched in 2007. ${ }^{199}$ As part of the NICFI, Norway has pledged 1.6 billion US dollars in funding to support the global advance of REDD+ through contributions to established multilateral programs and funds as well as direct partnerships with seven developing countries: Brazil, Guyana, Ethiopia, Indonesia, Mexico, Tanzania, and Vietnam. ${ }^{200}$ Through a combination of diplomacy, development aid, research, and technical assistance, the NICFI "seeks to influence the policy process by adding momentum to finalising an international REDD+ agreement, contributing to the detail of the emerging mechanisms and establishing real examples through national-level agreements with key

countries. See Multi-Partner Trust Fund Office, "UN REDD Programme Fund," available at: http://mptf.undp.org/factsheet/fund/CCFoo (accessed 5 May 2016); UN-REDD Programme, "Regions and Countries Overview" www.un-redd.org/Partner_Countries/tabi d/102663/Default.aspx (accessed 5 May 2016). See, e.g., FCPF Charter, supra note 191; UN-REDD Framework Document, supra note 192. See, e.g., Readiness Preparation Proposal Template Document, Version 6, (23 November 2011), available at: www.unredd.net/index.php?option $=$ com_docman\&task=doc_downloa $\mathrm{d} \&$ gid $=6869$ \& Itemid $=53$ (accessed 30 December 2013), Annex 4.

See e.g., FCPF, Common Approach to Environmental and Social Safeguards for Multiple Delivery Partners (9 August 2012), available at: www.forestcarbonpartnership.org/sites/forest carbonpartnership.org/files/Documents/PDF/Augzo12/FCPF\%zoReadiness\%zoFund\%zoC ommon\%20Approach\%208-9-12.pdf (accessed 30 December 2013).

See, e.g., R-PP Template Document, supra note 195, Annex B, Joint Guidelines for Stakeholder Engagement.

199 Other important bilateral initiatives supporting the global implementation of REDD+ have also been established by Australia, France, Germany, Japan, the United Kingdom, and the United States. See Liane Schalatek, Alice Caravani, Smita Nakhooda \& Charlene Watson, "Climate Finance Thematic Briefing: REDD+ Finance," available at: www.odi .org/sites/odi.org.uk/files/odi-assets/publications-opinion-files/7912.pdf (accessed 18 July 2014).

200 Norwegian Ministry of Climate and the Environment, "How are the funds being spent?" available at: www.regjeringen.no/en/dep/kld/kampanjer/the-governments-climate-and-treeproject/how-are-the-funds-being-spent.html?id=734170 (accessed 18 July 2014); Norwegian Ministry of Climate and the Environment, "Who are our Collaboration Partners?" available at: www.regjeringen.no/en/dep/kld/kampanjer/the-governments-climate-and-tree-project/ who-are-our-collaboration-partners.html?id=733948 (accessed 18 July 2014). 
REDD-relevant countries." ${ }^{201}$ The legal norms for REDD+ have taken on two main forms in bilateral initiatives: the law, policy, or regulation that governs a bilateral REDD+ program $^{202}$ and the bilateral agreements between the government or agency of a developed country and its developing country partner that provide the terms and conditions for the delivery of REDD+ finance and assistance. ${ }^{203}$

At the transnational level, the most significant sites of law for REDD+ are the nongovernmental programs and initiatives that NGOs and corporations have established to guide and support the jurisdictional REDD+ efforts of developing countries and those that aim to sustain and govern the voluntary market for project-based REDD+ activities. To begin with, several large international conservation NGOs ${ }^{204}$ major management and consulting firms working on the low-carbon economy, ${ }^{205}$ and specialized firms active in carbon finance and trading ${ }^{206}$ have created their own programs of research, capacity-building, training, technical assistance, and finance for REDD+

201 NORAD, "Real-Time Evaluation of Norway's International Climate and Forest Initiative. Contributions to a Global REDD+ Regime 2007-2010,” March 2011, available at: www.regj eringen.no/upload/MD/2o11/vedlegg/klima/klima_skogprosjektet/Evalueringsrapportene/Re port_12_2010_Global_web.pdf at xiv.

202 See, e.g., Norwegian Ministry of Environment, Norwegian Climate Policy, Recommendation from the Ministry of the Environment, 25 April 2012, approved by the Cabinet on the same date (Stoltenberg II Government), Report No. 21 to the Storting (2011-2012), available at: www.reg jeringen.no/pages/38117723/PDFS/STM201120120021000EN_PDFS.pdf (accessed 2 September 2014) at 11; Norwegian Ministry of Foreign Affairs, Climate, Conflict and Capital. Norwegian development policy adapting to change, Report No. 13 to the Storting (2008-2009), available at: www.regjeringen.no/pages/2171591/PDFS/STM200820090013000EN_PDFS.pdf (accessed 2 September 2014) at 54-56.

203 See, e.g., Memorandum of Understanding between the Government of the Cooperative Republic of Guyana and the Government of the Kingdom of Norway regarding Cooperation on Issues related to the Fight against Climate Change, the Protection of Biodiversity and the Enhancement of Sustainable Development (November 2009), available at: www.regjerin gen.no/upload/MD/Vedlegg/Klima/klima_skogprosjektet/The\%zoMemorandum\%zoof\%zo Understanding\%zoGuyana\%20Norway\%20on\%20REDD\%20(081109)\%zosigned\%20091109 .pdf (accessed 18 July 2014).

204 See, e.g., WWF, "Natural Forests Protect against Climate Change," available at: wwf.panda .org/what_we_do/where_we_work/greatermekong/our_solutions/redd/ (accessed 15 December 2013); and Conservation International, "REDD+," available at: www.conservation.org/learn/c limate/solutions/mitigation/Pages/climate_REDD.aspx (accessed 15 December 2013).

205 See, e.g., McKinsey \& Co., "Carbon and Energy Economics," available at: www.mckinsey .com/client_service/sustainability/expertise/carbon_and_energy_economics (accessed 15 December 2013); Price Waterhouse Coopers, "Forest Carbon and REDD," available at: www.pwc.co.uk/sustainability-climate-change/issues/can-forests-help-to-solve-climatechallenges.jhtml (accessed 15 December 2013).

206 See, e.g., Climate Focus, "Focus Areas: REDD+," available at: www.climatefocus.com/pag es/redd_plusLTS International (accessed 15 December 2013); LTS International, "Our Services: REDD+," available at: www.ltsi.co.uk/services/redd/ (accessed 15 December 
activities at multiple levels. These NGOs and corporations have most notably established voluntary initiatives to guide the REDD+ readiness activities carried out by developing country governments. One of the most influential initiatives of this type is the Jurisdictional and Nested REDD+ (JNR) Framework established by the Verified Carbon Standard (VCS) in December 2010 to provide accounting methodologies and rules for the certification of national and subnational REDD+ activities undertaken by governments. ${ }^{207}$ Another important transnational initiative is the REDD+ Social and Environmental Safeguards (REDD+ SES), a multi-stakeholder process launched in May 2009 to develop a set of voluntary social and environmental safeguards for government-led jurisdictional REDD+ programs and activities. ${ }^{208}$

In addition, NGOs and corporations have also supported the formation of a voluntary market for carbon credits generated through REDD+ projects aiming to reduce emissions from forestry-related sources at the subnational level. NGOs and corporations have carried out, brokered, and audited REDD+ activities in line with established methodologies and accounting standards for their development, validation, and certification. The two sets of standards with the greatest share of REDD+ projects worldwide are: ${ }^{209}$ the Agriculture, Forestry \& Land Use (AFOLU) Requirements of the Verified Carbon Standard $(\mathrm{VCS})^{210}$ and the Climate, Community \& Biodiversity (CCB) Standards. ${ }^{211}$ Both the VCS and the CCB Standards serve as sites of law for the pursuit of project-based REDD+ activities: they set the rules for carrying out, monitoring, and evaluating projects, provide guidance and methodologies for the application of these rules, create a process for the accreditation of third-party auditors for the validation and verification of such projects,

2013); Wildlife Works, "About Us," available at: www.wildlifeworks.com/company/aboutus .php (accessed 15 December 2013).

207 VCS, "Jurisdictional and Nested REDD+ (JNR)," available at: www.V-c-s.org/JNR (accessed 15 December 2013).

208 REDD+ SES, "About the REDD+ SES," available at: www.redd-standards.org (accessed 15 December 2013). Several jurisdictions have thus far voluntarily decided to participate in the development or implementation of the REDD+ SES, most notably the State of Acre in Brazil, the Province of Central Kalimantan in Indonesia, Ecuador, Nepal, and Tanzania.

209 According to the leading industry survey of forest carbon projects, 71 percent of all forest carbon projects and transactions in 2013 obtained certification from both the VCS and the CCB Standards (Molly Peters-Stanley, Allie Goldstein \& Gloria Gonzalez, Turning Over a New Leaf State of the Forest Carbon Markets 2014 (Washington, DC: Ecosystem Marketplace, 2013) at 58).

210 VCS, "Agriculture and Forestry Projects," available at: www.v-c-s.org/develop-project/agricul ture-forestry-projects (accessed 22 July 2014).

${ }^{211}$ Climate, Community \& Biodiversity Alliance, "CCB Standards," available at: www.climatestandards.org/ccb-standards/ (accessed on 22 July 2014). 
and establish procedures for addressing disputes and improprieties in the application of the standards. ${ }^{212}$

At the national level, legal norms for REDD+ have been constructed in and conveyed through the pursuit of jurisdictional REDD+ readiness activities. Over 6 o governments throughout the developing world have initiated national multi-year readiness programs to lay the groundwork for the domestic operationalization of jurisdictional REDD+ in accordance with the UNFCCC COP's guidance and with the support and technical assistance provided by bilateral, multilateral, and nongovernmental partners. ${ }^{213}$ These REDD+ readiness programs involve some combination of strategic planning, policy analysis and development, legal and institutional reform, public consultation and stakeholder engagement, capacity-building and training, and demonstration projects that aim to ensure that a developing country has achieved the conditions required for REDD+ to be implemented on a jurisdictional scale. ${ }^{214}$

There are two main ways in which the pursuit of jurisdictional REDD+ readiness programs may entail the construction and conveyance of legal norms. First, the adoption of a national strategy for jurisdictional REDD+ provides an opportunity for a developing country government to design a tailored framework for the governance of REDD $+{ }^{215}$ In order to prepare developing countries for the operationalization of REDD+, a national strategy should deal with matters such as the modalities through which international payments for REDD+ will be managed and channeled in a country; ${ }^{216}$ the arrangements for sharing benefits from these payments with stakeholders at multiple levels; ${ }^{217}$ the clarification of land and forest rights and tenure in areas that are targeted for REDD+ policies and measures; ${ }^{218}$ and the participation and engagement of multiple stakeholders. ${ }^{219}$ In turn, the development and

212 See Anja Kollmuss, Helge Zink \& Clifford Polycarp, Making Sense of the Voluntary Carbon Market: A Comparison of Carbon Offset Standards (Berlin, Germany: WWF Germany, 20o8).

213 Annex I. Overview of REDD+ Activities in the Developing World.

214 Sheila Wertz-Kanounnikoff \& Arild Angelsen, "Global and National REDD+ Architecture Linking Institutions and Actions" in Angelsen, Realising REDD+, supra note 180, 13 at 13-24.

215 Charlotte Streck, "Reducing Emissions from Deforestation and Forest Degradation: National Implementation of REDD Schemes - an Editorial Comment" (2010) 3-4 Climatic Change 389; John Costenbader, Legal Frameworks for REDD Design and Implementation at the National Level, IUCN Environmental Policy and Law Paper 77 (2009).

216 Hall, supra note 183 at 58-61.

217 Cecilia Luttrell et al., "Who Should Benefit from REDD+? Rationales and Realities" (2013) 18:4 Ecology ש Society 52.

218 Anne M. Larson et al., "Land Tenure and REDD+: The Good, the Bad and the Ugly" (2013) 23:3 Global Environmental Change 678.

219 Tim Forsyth, "Multilevel, Multiactor Governance in REDD+ Participation, Integration and Coordination" in Angelsen, Realising REDD+, supra note 181, 113. 
implementation of national REDD+ strategies entails the interpretation and application of existing laws and regulations in relevant areas (especially forestry, climate change, land-use, property, and human rights). ${ }^{220}$

Second, jurisdictional REDD+ readiness efforts may also lead to the development and adoption of new laws and regulations. Some of these new laws and regulations have specifically focused on the regulation of REDD+ activities, ${ }^{221}$ including project-based ones. ${ }^{222}$ Other legal, policy, and regulatory reforms have been developed with the aim of achieving actual reductions in carbon emissions from the forestry and land-use sectors. ${ }^{223}$ For instance, developing countries have imposed a moratorium on the exploitation of forests ${ }^{224}$ or adopted reforms aimed at strengthening forest governance through improved land-use planning, land titling, and enforcement measures. ${ }^{225}$

At the subnational level, legal norms for REDD+ have been constructed in and conveyed through two types of activities. First, the governments of a number of sub-national jurisdictions, most notably including provincial governments in Brazil, Indonesia, and Mexico, have initiated their own jurisdictional readiness programs. ${ }^{226}$ The design and aims of these subnational jurisdictional readiness programs are very similar to the national ones discussed above and are meant to form part of a nested approach to REDD+, in which

220 UN-REDD Programme, Legal analysis of cross-cutting issues for REDD+ implementation: Lessons learned from Mexico, Viet Nam and Zambia (Geneva, Switzerland: UN-REDD Programme, 2013).

${ }_{221}$ See the entry for law in the REDD+ Desk, available at: http://theredddesk.org/countries/sea rch-countries-database?f[o]=type\%3Alaw\&f[1]=field_primary_focal_area\%3Aredd (accessed 2 September 2014).

222 See, e.g., Government of Indonesia, Ministry of Forestry of the Republic of Indonesia, "Ministerial Regulation P. 20/Menhut-II/2012 on Implementation of Forest Carbon," available at: http://theredddesk.org/sites/default/files/ministerial_regulation_on_implementatio n_of_forest_carbon_3.pdf (accessed 9 December 2014).

223 Arild Angelsen, "Policy Options to Reduce Deforestation" in Angelsen, Realising REDD+, supra note 181, 125.

224 See, e.g., Government of Indonesia, Presidential Instruction no. 10/2011 Regarding Suspension of Granting of New Licenses and Improvement of Governance of Natural Primary Forest and Peat Land, available at: http://theredddesk.org/countries/policies/presi dential-instruction-no-102011-regarding-suspension-granting-new-licenses-and (accessed 2 September 2014).

225 See, e.g., Government of Brazil, Ministério do Meio Ambiente, "Plano de Prevenção e

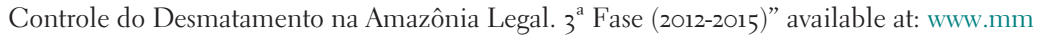
a.gov.br/images/arquivo/80120/PPCDAm/_FINAL_PPCDAM.PDF (accessed 2 September 2014).

226 Daniel Nepstad et al., Overview of Subnational Programs to Reduce Emissions from Deforestation and Forest Degradation (REDD) as Part of the Governors' Climate and Forests Task Force (Palto Alto, California: Electric Power Research Institute, 2012). 
readiness and early demonstration activities may be initiated at the subnational level in lead-up to the establishment of a national REDD+ framework and the pursuit of a related set of jurisdictional interventions at the national level. ${ }^{227}$ Legal norms for REDD+ have thus been formally enacted through the adoption of laws, policies, and regulations in these subnational jurisdictions. ${ }^{228}$

Second, a multiplicity of public and private actors (including international organizations, national, subnational, and local governments, international and local NGOs and corporations, and local communities) has initiated REDD+ projects that aim to reduce carbon emissions at the subnational level. Close to 350 such projects have been developed in more than 50 developing countries across Africa, Asia, and Latin America and the Caribbean. ${ }^{229}$ In 2014, these projects accounted for the largest share of carbon market activity and had a total market value of 94 million US dollars. ${ }^{230}$ These market-based projects and transactions generate multiple forms of law, including the project design document that must be submitted to the certification program and validated and verified by third-party auditors; the contracts, protocols, or agreements that must be signed with local communities or other affected stakeholders, the licenses and regulatory approvals that must be obtained from local authorities; and the agreement enabling the sale or trading of carbon credits generated by the project. ${ }^{231}$

\subsection{THE COMPLEXITY OF THE TRANSNATIONAL LEGAL PROCESS FOR REDD+}

From its origins as a promising and relatively straightforward UNFCCC mechanism with "triple-win" potential for forests, climate change, and

227 Lucio Pedroni, Manuel Estrada Porrua \& Mariano Colini Cenamo, "The 'Nested Approach' to REDD+: How Could it Be Implemented?" in Xianli Zhu et al., eds., Pathways for Implementing REDD+. Experiences from Carbon Markets and Communities (Nairobi, Kenya: UNEP, 2010) 89 .

${ }_{228}$ See, e.g., The Governor of Central Kalimantan, "Regulation of the Governor of the Province of Central Kalimantan Number 102012 regarding the Regional Strategy and Action Plan for Reducing Emissions from Deforestation and Forest Degradation - Plus in Central Kalimantan Province," available at: www.gcftaskforce.org/documents/Central\%zoKalimant an\%20Governor\%20Regulation_10_2012_EN.pdf (accessed 2 September 2014).

229 Annex I. Overview of REDD+ Activities in the Developing World.

230 Molly Peters-Stanley \& Gloria Gonzalez, Sharing the Stage: State of the Voluntary Carbon Markets 2014 (Executive Summary) (Washington, DC: Ecosystem Marketplace, 2014) at xiv.

${ }^{231}$ See generally Slayde Hawkins, "Legal Guidance: Legal and Contractual Aspects of Forest Carbon Projects" in Johannes Ebeling \& Jacob Olander, eds., Building Forest Carbon Projects. Step-by-Step Overview and Guide (Washington, DC: Forest Trends, 2011). 
sustainable development, the transnational legal process for REDD+ has evolved to become increasingly complex over time. ${ }^{232}$ As various actors have moved forward with the operationalization of REDD+, the challenges, risks, and trade-offs that had been obscured or ignored at an earlier stage in the emergence of REDD+ have begun to resurface. ${ }^{233}$ In particular, the transnational legal process for REDD+ has become intertwined with the conflicting coalitions and agendas that shape the domain of forest governance within developing countries ${ }^{234}$ and "entangled in fundamental debates about justice and equity from local to global levels." ${ }^{235}$ To be sure, the involvement of a diverse array of private and civil society actors has also accentuated disagreements about the fundamental purposes and principles of REDD+ within the UNFCCC. ${ }^{236}$ This has most notably included civil society actors who are skeptical about its potential benefits for climate mitigation and concerned about its implications for other important social and environmental considerations. ${ }^{237}$ Indeed, the research, advocacy, and conservation NGOs that have pressed for the recognition of the rights of Indigenous Peoples and local communities in international law and policy over the last 40 years have brought their energies and efforts to the transnational legal process for REDD+, which has provided a new and significant venue for advancing their agenda. ${ }^{23^{8}}$ As this book reveals, debates over whether and how to protect the rights of Indigenous Peoples and local communities in the context of REDD+ activities are a cause as well as a reflection of the growing complexity of the transnational legal process for REDD+.

In addition, as REDD+ has spread across multiple sites of law, the transnational legal process for REDD+ has also been characterized by

232 McDermott et al., "Operationalizing Social Safeguards" supra note 54 at 65; Streck \& Costenbader, supra note 54 at 2; Esteve Corbera \& Heike Schroeder, "Governing and Implementing REDD+" (2011) 14:2 Environmental Science \& Policy 89 at 90-93.

233 Okereke \& Dooley, supra note 9 at 83; Till Pistorius, "From RED to REDD+: The Evolution of a Forest-Based Mitigation Approach for Developing Countries" (2012) 4:6 Current Opinion in Environmental Sustainability 638 at 642; McDermott et al., "Operationalizing Social Safeguards" supra note 54 at 65.

234 See Kristen Evans, Laura Murphy \& Wil de Jong, "Global versus Local Narratives of REDD: A Case Study from Peru's Amazon" (2014) 35 Environmental Science \& Policy 98; Alex Shankland \& Leonardo Hasenclever, "Indigenous Peoples and the Regulation of REDD+ in Brazil: Beyond the War of the Worlds?" (2011) 42:3 IDS Bulletin 80; Olufunso A. Somorin et al., "The Congo Basin Forests in a Changing Climate: Policy Discourses on Adaptation and Mitigation (REDD+)" (2012) 22:1 Global Environmental Change 288.

235 Okereke \& Dooley, supra note 9 at 93. See also Schroeder \& McDermott supra note 11.

${ }_{236}$ den Besten, Arts \& Verkooijen, supra note 169 at 43-44; Corbera \& Schroeder, supra note 232 at 92 .

237 See generally Interview 7; Interview 81; Interview 82.

${ }_{23} 8$ See Sikor \& Stahl, supra note 11. 
TABLE 1.3. Potential pathways and related causal mechanisms for the conveyance of legal norms in the transnational legal process for REDD+

\begin{tabular}{cc}
\hline \hline $\begin{array}{c}\text { Conditions set by international and transnational sites of } \\
\text { law for funding jurisdictional and project-based REDD+ }\end{array}$ & $\begin{array}{c}\text { Cost-benefit Adoption } \\
\text { Coercion }\end{array}$ \\
activities at the national level and subnational levels & \\
Opportunities for socialization between actors provided by & $\begin{array}{c}\text { Élite internalization } \\
\text { Acculturation }\end{array}$ \\
international, transnational, national, and subnational & \\
sites of law & Instrumental Learning \\
Generation and dissemination of knowledge about & \\
experiences with the design and implementation of & \\
jurisdictional and project-based REDD+ activities & Mobilization \\
Opportunities for advocacy provided by international, \\
transnational, national, and subnational sites of law
\end{tabular}

multidirectionality. From 2007 onward, the construction of legal norms for REDD+ within the UNFCCC contended with, and was influenced by, the legal norms for REDD+ constructed in multiple sites of law. ${ }^{239}$ As is often the case with a transnational legal process, the conveyance of legal norms for REDD+ from one site of law to another has given rise to the construction of hybrid legal norms and has created opportunities for their further conveyance across other sites of law. In what follows, I identify four potential pathways and related causal mechanisms through which actors may trigger the conveyance of legal norms to, from, and across sites of law at the international, transnational, national, and local levels (Table 1.3).

A first pathway relates to the conditions that international and transnational sites of law have set for accessing sources of finance for jurisdictional and project-based REDD+ activities and the ways in which these conditions may create incentives for implementing a particular set of legal norms at the national and subnational levels. In order to trigger the conveyance of legal norms, the conditions set by these sites of law would need to provide material or reputational incentives for compliance by actors in another site of law (cost-benefit adoption) as well as opportunities for exogenous actors to detect and sanction instances of noncompliance (coercion). By way of example, the FCPF, the UN-REDD Programme, and NICFI have made the delivery of the funding they provide to developing countries for their jurisdictional REDD+ readiness efforts contingent on respect for social and environmental safeguards and

239 Seymour \& Angelsen, supra note 187 at 319; Corbera \& Schroeder, supra note 132 at 90-93. 
other standards. ${ }^{240}$ The domestic influence of these conditions in the context of REDD+ readiness activities could thus be expected to depend on the credibility and independence of their processes for the monitoring and evaluation of REDD+ readiness finance and their willingness to suspend funding arrangements in case of noncompliance. ${ }^{241}$ Another example relates to the market incentives provided by the CCBA for the design and implementation of REDD+ projects that comply with its social and environmental standards. REDD+ projects certified with the CCB label have indeed attracted a premium on the voluntary carbon market. ${ }^{242}$ More broadly, given that most of the start-up funding that currently exists for REDD+ projects originates in development aid and that corporate social responsibility is the primary motivation for buyers of REDD+ credits, the CCB label has increasingly become a basic requirement for entry into the voluntary carbon market. ${ }^{243}$

A second pathway pertains to the manner in which the transnational legal process for REDD+ has provided opportunities for actors to socialize with one another and convey legal norms across multiple sites of law. As a result of socialization, actors may internalize legal norms because they have been actively convinced of their appropriateness (élite internalization) or because of their desire to adopt norms that have been widely accepted in their broader transnational reference group (acculturation). I will briefly mention two opportunities for socialization that have emerged from the transnational legal process for REDD+. To begin with, actors have socialized with one another as a result of their participation in the construction of legal norms in sites such as the UNFCCC, the FCPF, the UN-REDD Programme, the REDD+ SES, and the CCBA. Each of these sites has emphasized, to varying degrees, the sort of deliberation and inclusion that is generally seen by scholars as facilitating the generation of norms in a site of law.

240 FCPF Charter, supra note 192 at Section 3.1(d); UN-REDD Programme Framework Document, supra note 193 at 12; Memorandum of Understanding between the Government of the Cooperative Republic of Guyana and the Government of the Kingdom of Norway regarding Cooperation on Issues related to the Fight against Climate Change, supra note 203 .

${ }^{241}$ There is at least one case involving noncompliance in relation to a complaint made by Indigenous Peoples with respect to the UN-REDD National Programme in Panama. See Fréchette et al., supra note 347 at 59 and 62-64; NORAD, supra note 423 at 476-477.

242 Kelley Hamrick et al., Ahead of the Curve: State of the Voluntary Carbon Markets 2015 (Washington, DC: Ecosystem Marketplace, 2015) at 17.

243 Interview 34 at 1-2; Interview 47 at 7 ; Interview 73 at 6; Interview 77 at 3; Interview 80 at 1 . See also Rachel Godfrey Wood, "Carbon Finance and Pro-Poor Co-Benefits: The Gold Standard and Climate, Community and Biodiversity Standards" (London, UK: IIED, 2011) at 29; Peters-Stanley et al., supra note 209 at 16. 
In addition, these sites of law may also facilitate interactions between actors situated in or across other levels of law. One important example relates to the process for the review and approval of multilateral REDD+ readiness grants under the FCPF and the UN-REDD Programme. This process begins with the preparation and submission by a developing country government of a Readiness Preparation Proposal (R-PP), ${ }^{244}$ which must be drafted in accordance with an established template that outlines six necessary components of jurisdictional readiness for REDD+. ${ }^{245}$ This R-PP requires developing countries to address legal, policy, and governance issues relating to their jurisdictional REDD+ readiness processes and to ensure the full and effective participation of Indigenous Peoples and local communities in the design and implementation of activities. ${ }^{246}$ The process by which an R-PP is approved for funding has generally followed a lengthy and transparent review process that has enabled multilateral agencies and their governing bodies, bilateral partners, and civil society actors to suggest changes in the first drafts of R-PPs submitted by developing country governments. ${ }^{247}$

A third pathway is connected to the generation and sharing of knowledge about the enactment and implementation of legal norms within the transnational legal process for REDD+. This knowledge may lead actors in a given site of law to enact or implement an exogenous legal norm based on the evidence that they have acquired about the utility of doing so from the experience of other sites of law (instrumental learning). The transnational legal process for REDD+ has supported instrumental learning through the

244 Readiness Preparation Proposal Template Document, Version 6, (23 November 2011), available at: www.unredd.net/index.php?option=com_docman\&task=doc_download \&gi $\mathrm{d}=6869 \&$ Itemid $=53$ (accessed 30 December 2013).

245 Namely: (1) management arrangements and stakeholder engagement processes; (2) the preparation of a national REDD+ strategy; (3) the development of a national forest reference emission level or forest reference level; (4) the design of systems for MRV and reporting on safeguards and multiple benefits; (5) a schedule and budget; and (6) the design of a program monitoring and evaluation framework.

246 See, e.g., R-PP Template Document, supra note 243 at 4, 6, 9, 10, 15, 16, 20-22, 25-28, 36-37, $40-42,46-50,57-58$, and 61-62.

247 When the R-PP template document is submitted to the FCPF, it is first reviewed by an independent Technical Advisory Panel (TAP) and submitted for final approval to the FCPF Participants Committee (PC). Likewise, R-PPs submitted to the UN-REDD Programme are first reviewed by experts in the UN-REDD Programme Secretariat, and then submitted for a final decision to the UN-REDD Programme Policy Board, which includes REDD+ country partners and donors, one Indigenous representative, and one a civil society representative. As a result, many R-PPs have undergone at least one round of revisions before they have been approved for funding by the FCPF or the UN-REDD Programme and have frequently incorporated significant changes suggested by other interlocutors, including NGO representatives. See also Independent Evaluation Group, supra note 317 at 31. 
production and dissemination of knowledge products as well as the provision of training, capacity-building, and technical assistance for the implementation of REDD+. For instance, the FCPF and the UN-REDD Programme have released guidelines, tools, and other knowledge products that have provided developing countries with concrete guidance on how to respect and operationalize the rights of Indigenous Peoples and local communities in the context of their jurisdictional REDD+ readiness activities. ${ }^{248}$ The REDD+ SES Initiative has also played a key role in developing and disseminating a methodology for the development of a set of social and environmental safeguards. ${ }^{249}$ Likewise, the CCB Standards and related guidelines that the CCBA has released provide a methodology for the design, planning, and implementation of a REDD+ project. ${ }^{25}$ Lastly, early experiences with the implementation of jurisdictional REDD+ activities as well as project-based REDD+ activities may also have exerted influence on other sites and levels of law for REDD+. For instance, negotiators within the UNFCCC have drawn on the knowledge generated by the pursuit of REDD+ readiness activities in developing countries and the rules provided by the multilateral, bilateral, and nongovernmental initiatives for REDD+. ${ }^{251}$ Additionally, the implementation of REDD+ pilot projects in developing countries may, to some extent, have fed into their jurisdictional readiness efforts ${ }^{252}$ as well as influenced other sites and levels of law. ${ }^{253}$

A fourth and final pathway relates to the way in which the transnational legal process for REDD+ has provided enhanced opportunities for Indigenous

${ }^{248}$ With respect to the FCPF, see NORAD, supra note 423 at 437 . With respect to the UNREDD programme, see Fréchette et al., supra note 347 at 62-64.

249 REDD+ SES, Guidelines for the Use of REDD+ Social E Environmental Standards at Country Level, Version 2, 16 November 2012, available at: www.redd-standards.org/files/pdf/ redd-docs/Standards/REDD_SES_Guidelines_Version_2_-_16_November_2012.pdf (accessed 30 December 2013).

250 CCBA, Rules for the Use of the Climate, Community \& Biodiversity Standards, 2013, available at: https://sz.amazonaws.com/CCBA/Third_Edition/Rules_for_the_Use_of_the_CCB_Stan dards_December_2013.pdf (accessed 24 September 2014).

251 Interview 11 at 11 ; Interview 21 at 1; Interview 38 at 3; Interview 42 at 7 ; Interview 44 at 7 ; Baastel \& NORDECO, First Program Evaluation for the Forest Carbon Partnership Facility (FCPF). Evaluation Commissioned by the Participants Committee of the FPCF (June 2011), available at: www.forestcarbonpartnership.org/sites/forestcarbonpartnership.org/files/Documents/PD F/Junzo11/5.\%2oFinal\%2oFCPF_EVALUATION_REPORT_June\%2013th.pdf (accessed 27 September 2014) at 30. See also den Besten, Arts \& Verkooijen, supra note 169 at 46; Sabine Reinecke, Till Pistorius \& Michael Pregernig, "UNFCCC and the REDD+ Partnership from a Networked Governance Perspective" (2014) 35 Environmental Science E Policy 30 at 36.

252 Frances Seymour \& Arild Angelsen, "Summary and Conclusions: REDD Wine in Old Wineskins?" in Angelsen, Realising REDD+, supra note 181, 293 at 297.

253 Pamela Jagger, Stibniati Atmadja, Subhrendu K. Pattanayak, Erin Sills \& William D. Sunderlin, "Learning While Doing. Evaluating Impacts of REDD+ Projects" in Angelsen, Realising REDD+, supra note 181, 281 at 281-282. 
Peoples and local communities to advocate for the recognition and protection of their rights vis-à-vis international, transnational, national, and local authorities (mobilization). By way of example, the FCPF, the UN-REDD Programme, and the REDD+ SES require that the proponents of jurisdictional REDD+ activities carry out extensive stakeholder engagement and consultation processes at the national level. ${ }^{254}$ These consultations have provided unique platforms for Indigenous Peoples and Civil Society Organizations (CSOs) to advocate for the recognition and protection of their participatory and substantive rights in the context of jurisdictional REDD+ readiness efforts. ${ }^{255}$ In addition to providing Indigenous Peoples and local communities with an opportunity for advocacy, international and transnational sites of law have also developed mechanisms to provide them with funding and otherwise support their participation in domestic REDD+ activities, including in the pursuit of project-based REDD+ activities. ${ }^{256}$ As a result, the pursuit of jurisdictional REDD+ activities may have provided

254 With respect to the FCPF and the UN-REDD Programme, see R-PP Annexes, at 10; R-PP Template Document, at 16. With respect to the REDD+ SES, see REDD+ SES, "REDD+ Social \& Environmental Standards" Version 2, 10 September 2012, available at: www.reddstandards.org (accessed 4 April 2016) at Principle 6.

255 Interview 40 at 9; Interview 57 at 6; Interview $5^{8}$ at 4-5. Observations gathered during participation in GIZ/UN-REDD/FCPF workshop on the full and effective participation of Indigenous Peoples in REDD+ (Weilburg, Germany, September 2013) and GEM/CLUA workshop on the promotion of community forestry (Washington DC, January 2014). In relation to the UN-REDD Programme, see also Fréchette et al., supra note 347 at 41 (arguing that the UN-REDD Programme has "effectively provided an unprecedented platform for Indigenous Peoples' and civil society organizations to voice not only their concerns, needs, and interests, but in fact their rights - whether to free, prior and informed consent, customary or statutory land rights, resource rights, or equity in benefit sharing processes."); NORAD, supra note 423 at 475 . In relation to the FCPF, see also Independent Evaluation Group, supra note 317 at xix; NORAD, supra note 423 at 434.

256 For instance, the FCPF has a program dedicated to funding activities proposed by forestdependent Indigenous Peoples (IPs) and other forest dwellers, and seeks to enhance their knowledge and capacity with respect to REDD+ and support their engagement in REDD+ activities (Forest Carbon Partnership Facility (FCPF), "Capacity Building Program for Forest-Dependent People on REDD plus” (22 February, 2010), available at: www.forestcar bonpartnership.org/sites/fcp/files/Documents/tagged/FCPF_FMT_Note_2010-8_IP_Capaci ty_Building_02-22-10\%5B1\%5D.pdf (accessed 30 December 2013)). The UN-REDD Programme, along with the GEF, has also created a support scheme for community-based REDD+ to enable "communities themselves to initiate activities, build capacities, exchange information, pilot methodologies, develop models of representation and participation, and implement their visions for REDD+ in alignment with national REDD+ goals and objectives." See UN-REDD Programme, "Concept Note for Support to Community-Based REDD+," available at: www.unredd.net/index.php?option=com_docman\&task=doc_down load \&gid $=10599 \&$ Itemid $=53$ (accessed 6 January 2014) at 2 . See UN-REDD Programme, Report of the Tenth Policy Board Meeting, Lombok, Indonesia, 26-27 June 2013 available at: www.unredd.net/index.php?option=com_docman\&task=doc_download \&gid=10820\&Itemi $\mathrm{d}=53$ (accessed 6 January 2014) at 5 . 
Indigenous Peoples Organizations (IPOs) and CSOs with additional resources and new opportunities for mobilizing on issues relating to the recognition and protection of the rights of Indigenous Peoples and local communities. Similarly, the CCB Standards require that the proponents of REDD+ projects conduct consultations with affected communities and other appropriate stakeholders, ${ }^{257}$ thus providing another opportunity for mobilization and advocacy on the part of Indigenous Peoples and local communities.

To some extent, the plural, heterogeneous, and multidirectional nature of the transnational legal process for REDD+ aligns with the aspirations of many actors to experiment with, and learn from, the implementation of REDD+ across multiple sites of law. ${ }^{258}$ On the other hand, there have been increasing concerns that the transnational legal process for REDD+ has become fragmented in ways that have created disconnects between different sites of law and related activities. As Corbera and Schroeder argue, REDD+ has evolved into "a slew of unorchestrated, multi-level, multi-purpose and multi-actor projects and initiatives" that "permeates multiple spheres of decision-making and organization, creates contested interests and claims, and translates into multiple implementation actions running ahead of policy processes and statedriven decisions." 259 This sort of fragmentation has complicated efforts to operationalize REDD+ in developing countries and has prompted efforts aimed at enhancing coordination and collaboration across a range of multilateral, bilateral, and nongovernmental initiatives. ${ }^{260}$ available at: https://s3.amazonaws.com/CCBA/Third_Edition/CCB_Standards_Third_Edit ion_December_2013.pdf (accessed 24 September 2014) at G3.

${ }_{258}$ Reinecke et al., supra note 251 at $36 . \quad 259$ Corbera \& Schroeder, supra note 232 at 93.

260 For instance, the UNFCCC has addressed issues relating to the coordination of REDD+ finance as part of a work program to improve its effectiveness (UNFCCC COP, Decision $2 /$ CP.17 at paras 65). See also the discussion of the REDD+ partnership in Reinecke et al., supra note 251 . 


\section{Rights and REDD+ in International and Transnational Law}

\subsection{THE EMERGENCE OF RIGHTS IN THE FIELD OF REDD+}

As was the case in other domains of climate governance until the second half of the 200os, human rights issues were not accorded much importance in the initial development of REDD+. ${ }^{261}$ For instance, the UNFCCC COP's first decision on REDD+ in December 2007 avoided rights-based language and merely acknowledged that "the needs of local and indigenous communities should be addressed when action is taken to reduce emissions from deforestation and forest degradation in developing countries." ${ }^{262}$ In addition, the UNFCCC COP failed to recognize the status and rights of Indigenous Peoples under international law in the decision on REDD+ that it adopted in December 2008, ${ }^{26}$ prompting the Indigenous Peoples' caucus to walk out of the UNFCCC negotiations under the rallying cry "No rights, no REDD." ${ }^{64}$ Ultimately, as I detail in this chapter, human rights standards have become an integral part of the legal framework for REDD+ developed within the UNFCCC and other international and transnational sites of law such as the World Bank FCPF, the UN-REDD Programme, the REDD+ SES, and the CCBA.

Two main processes can help explain the emergence of rights in the field of REDD+. To begin with, the neglect of human rights concerns in the UNFCCC and the subsequent propagation of REDD+ programs and activities around the world prompted IPOs and NGOs to initiate research

261 Jodoin, supra note 17 .

262 UNFCCC COP, Decision 2/CP.13, preamble [emphasis added].

263 Jodoin, supra note 17 at $167-168$.

${ }^{264}$ Lang, supra note 1. See also Victoria Tauli-Corpuz, "International Human Rights Day 2008: A sad day for indigenous peoples" (10 December 2008), available at: www.forest peoples.org/topics/un-framework-convention-climate-change-unfccc/news/2011/o5/interna tional-human-rights-day-200 (accessed 13 September 2014). 
and advocacy efforts in this new domain of transnational climate law. ${ }^{265}$ Throughout 2008 and 2009, a growing array of civil society organizations began to press for greater recognition of the rights of Indigenous Peoples and local communities in the context of REDD+ through a range of actions, including by releasing analysis and reports, ${ }^{266}$ and issuing statements and declarations, ${ }^{267}$ sharing information and coordinating advocacy efforts within civil society networks and caucuses, ${ }^{268}$ and lobbying governments within the UNFCCC, the REDD+ Partnership, the FCPF, and the UN-REDD Programme. ${ }^{269}$ In doing so, IPOs and NGOs most notably sought acknowledgment and protection of the rights enshrined in the UN Declaration on the Rights of Indigenous Peoples, including the right to free, prior, and informed consent, as well as in the wider set of international instruments that supported the collective rights of Indigenous Peoples and forest-dependent

See den Besten, Arts \& Verkooijen, supra note 169 at 43-44; Linda Wallbott, "Indigenous Peoples in UN REDD+ Negotiations: 'Importing Power' and Lobbying for Rights through Discursive Interplay Management” (2014) 19:1 Ecology \& Society, art. 21.

See, e.g., Victoria Tauli-Corpuz \& Aqqaluk Lynge, "Impact of climate change mitigation measures on indigenous peoples and on their territories and lands" E/C.19/2008/10 (19 March 2008); Rights \& Resources Initiative, Seeing People Through The Trees: Scaling Up Efforts to Advance Rights and Address Poverty, Conflict and Climate Change (2008), available at: www.rightsandresources.org/documents/files/doc_737.pdf (accessed 13 September 2014).

${ }_{267}$ See, e.g., Accra Caucus on Forests and Climate Change, "Accra Caucus Statement for COP 14” (December 2008), available at: http://unfccc.int/resource/docs/2008/smsn/ngo/o74.pdf (accessed 13 September 2014); Declaration on Climate Change and Indigenous Peoples of El Salvador (CCNIS 2009), Indigenous Peoples' Global Summit on Climate Change, “The Anchorage Declaration” (24 April 2009), available at: http:/unfccc.int/resource/docs/200g/sm sn/ngo/168.pdf (accessed 13 September 2014); and Tebtebba, "Press Statement of Tebtebba: Assessment of What Indigenous Peoples Have Gained So Far in the Negotiations in Bonn 2" (11 June 2009), available at: www.tebtebba.org/index.php/all-resources/category/84-redd-andad-and-indigenous-peoples?download=421:tebtebba-press-statement-on-the-bonn-climatetalks-11-june-2009 (accessed 13 September 2014).

268 Interview 81 at 1 . Key networks in the early stages were the Indigenous Peoples caucus, the Climate Action Network, the Accra Caucus on Forests and Climate Change, and the Human Rights \& Climate Change Working Group (Observations gathered during participation in

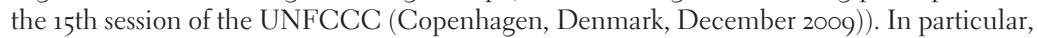
the Accra Caucus was formed in August 2008 by a coalition of forty NGOs from close to thirty countries for the explicit purpose of discussing and monitoring the development and implementation of REDD+ within the UNFCCC and beyond. See Interview 84 at $1-2$ and Rainforest Foundation, UK, “The Accra Caucus on Forests and Climate Change," available at: www.rainforestfoundationuk.org/Accra_Caucus (accessed 13 September 2014).

269 Interview 33 at 6; Interview 41 at 5-6; Interview 42 at 2; Interview 81 at 1-2; Interview 94 at 1. See also Wallbott, supra note 265 at 5-9; Victoria Tauli-Corpuz \& Lars-Ander Baer, "The Copenhagen Results of the UNFCCC: Implications for Indigenous Peoples' Local Adaptation and Mitigation Measures" E/C.19/2010/18 (2 March 2010) at para. 23. 
communities. ${ }^{270}$ These efforts eventually succeeded in having Indigenous rights issues included on the agendas of several key international and transnational sites of law for REDD+. These most notably included the UNFCCC, where governments began to incorporate references to Indigenous Peoples, their rights, and the UN Declaration on the Rights of Indigenous Peoples in their submissions on draft negotiating texts for REDD+. ${ }^{271}$

In addition, the launch of an extensive array of multilateral, bilateral, and nongovernmental finance, research, and capacity-building programs also supported the integration of human rights norms across the field of REDD+. Indeed, many actors in these other sites of law were already committed to the protection of human rights in their activities as a result of the spread of rightsbased approaches to conservation ${ }^{272}$ and development assistance ${ }^{273}$ as well as the growing importance accorded to the rights of Indigenous Peoples in the wake of the adoption of the UN Declaration of Indigenous Peoples. ${ }^{274}$ In turn, initial experiences with the implementation of REDD+ activities supported by multilateral, bilateral, and nongovernmental actors generated important insights about the utility of adopting social safeguards to govern the implementation of REDD+ activities. They also elucidated the range of legal obligations and standards by which these safeguards might protect the rights

270 Interview 3 at 1 ; Interview 41 at 4-5; Interview 81 at 2. See, e.g., "Indigenous Peoples and Local Communities' Global Strategy on REDD" Adopted at the Global Indigenous Peoples Consultation on Reducing Emissions from Deforestation and Forest Degradation (REDD) on 14 November 2008, available at: www.unutki.org/default.php?doc_id=133 (accessed 13 September 2014).

${ }^{271}$ With respect to governments, see the submissions by Bolivia, Ecuador, the European Union, Guatemala, Mexico, Panama, Costa Rica, Switzerland (on behalf of the Environmental Integrity Group), and Tuvalu (UNFCCC SBSTA, "Issues relating to indigenous people and local communities for the development and application of methodologies. Submissions from Parties." FCCC/SBSTA/2009/MISC.1 (10 March 2009); UNFCCC SBSTA, "Issues relating to indigenous people and local communities for the development and application of methodologies. Submissions from Parties. Addendum." FCCC/SBSTA/ 2009/MISC.1.Add.1 (17 April 2009); UNFCCC SBSTA, "Issues relating to indigenous people and local communities for the development and application of methodologies. Submissions from Parties. Addendum." FCCC/SBSTA/2009/MISC.1.Add.2 (27 May 2009)).

272 Thomas Sikor \& Johannes Stahl, "Introduction: The Rights-Based Agenda in International Forestry" in Sikor \& Stahl, supra note 11, 1-18; Sébastien Jodoin, "Can Rights-based Approaches Enhance Legitimacy and Cooperation in Conservation? A Relational Account" (2014) 15(3) Human Rights Review 283-303.

273 Bridgitte Hamm, "A Human Rights Approach to Development" (2001) 23 Human Rights Quarterly 1005.

274 See generally Xanthaki, supra note 38; James Youngblood Henderson, Indigenous Diplomacy and the Rights of Peoples: Achieving UN Recognition (Saskatoon, Saskatchewan: Purich Publishing, 2008); Rhiannon Morgan, Transforming Law and Institution. Indigenous Peoples, the United Nations and Human Rights (Surrey, UK: Ashgate Press, 2011). 
of Indigenous Peoples and local communities. ${ }^{275}$ Government officials and civil society representatives reporting on initial experiences with the pursuit of REDD+ on the ground shared these insights across the UNFCCC, the World Bank FCPF, the UN-REDD Programme, and other sites of law through formal and informal channels. ${ }^{276}$

In what remains of this chapter, I analyze the recognition of Indigenous and community rights in the context of three international sites of law (the UNFCCC, the World Bank Forest Climate Partnership Facility, and the UN-REDD Programme) and two transnational sites of law (the REDD+ SES and the CCBA). I conclude by highlighting some of the key differences that have emerged in relation to rights-related issues across these different sites of law.

\subsection{INDIGENOUS AND COMMUNITY RIGHTS IN UNFCCC DECISION-MAKING ON REDD+}

\subsubsection{The UNFCCC and the Transnational Legal Process for REDD+}

The UNFCCC is an international treaty that aims "to stabilize atmospheric concentrations of GHG at a level that would prevent human-induced actions from leading to "dangerous interference' with the global climate system." 277 In line with the "convention/protocol" model that is typical of many other multilateral environmental agreements, the UNFCCC establishes a set of common objectives and a forum for intergovernmental cooperation and dialogue on climate change. In turn, it is through the adoption of follow-up protocols that states may develop and take on binding obligations in relation to climate mitigation and adaptation efforts. ${ }^{278}$ As the "supreme body" of the UNFCCC, the COP is tasked with adopting decisions that promote its effective implementation. ${ }^{279}$ The COP meets annually and its decision-making requires the

275 den Besten, Arts \& Verkooijen, supra note 169 at 46.

${ }_{27} 6$ Interview 33 at 7 and 9; Interview 41 at $2-4$ and 7 ; and Interview 94 at 2 . Wallbott, supra note 265 at $7-8$. For an example of how such insights were shared within the UNFCCC see, e.g., UNFCCC SBSTA, "Report on the expert meeting on guidance on systems for providing information on how safeguards for REDD-plus activities are addressed and respected” UN Doc. FCCC/SBSTA/2011/INF.17 (10 November 2011).

277 UNFCCC, art. 2.

${ }_{278}$ Elisabeth DeSombre, Global Environmental Institutions (Abingdon, UK: Routledge, 2006) at 124 .

279 UNFCCC, art. 7.2. 
consensus (or near-consensus) of the 196 state parties to the UNFCCC. ${ }^{280}$ Relying upon the scientific and technical guidance provided by its Subsidiary Body for Scientific and Technological Advice (SBSTA), ${ }^{281}$ the COP adopts decisions that develop and operationalize new legal instruments (such as the Kyoto Protocol) and mechanisms (such as the CDM) in accordance with the UNFCCC's broader objectives and principles. Over the last two decades, existing research has shown that the legal norms developed through the decisions adopted by the COP have influenced the behavior and interactions of a range of public and private actors operating in the domain of climate change, ${ }^{282}$ under the auspices of the UNFCCC ${ }^{283}$ and beyond. ${ }^{284}$

The UNFCCC has played a critical role in the emergence of the transnational legal process for REDD+ by serving as the primary site for the construction of an initial set of legal norms for REDD+. These legal norms have spread to a variety of sites of law around the world and have prompted the development of myriad multilateral, bilateral, and nongovernmental schemes, tools, and programs to support jurisdictional as well as project-based REDD+ activities in developing countries. ${ }^{285}$ Although its influence has diminished within a broader transnational legal process that has grown more decentered and heterogeneous since 2007 , the UNFCCC has nonetheless remained an important international site of law for jurisdictional REDD+ activities. As part of the Cancun Agreements in 2010, ${ }^{286}$ the Durban Platform in 2011, ${ }^{287}$ and the

In fact, the UNFCCC COP has never managed to adopt rules of procedure and has therefore operated on the basis of an informal practice of consensus-based decision-making. However, at a number of sessions, the rule of consensus has not been interpreted to mean unanimous consent and decisions have been adopted over the objections of one party (Duncan French \& Lavanya Rajamani, "Climate Change and International Environmental Law: Musings on a Journey to Somewhere" (2013) 25 Journal of Environmental Law 1 at 13-15). Comprised of technical experts appointed by parties to the UNFCCC, the SBSTA provides guidance on scientific and technical matters identified by the COP (UNFCCC, art. 9).

282 This is not to say that the legal norms constructed by the UNFCCC COP have succeeded in actually resolving the problem of climate change. The point that I am making here is simply that the decision-making of the UNFCCC COP amounts to a form of law that has been found to steer the behavior of actors and influence other sites of law.

283 French \& Rajamani, supra note 280 at 7-12; Jutta Brunée, "COPing with Consent: LawMaking Under Multilateral Environmental Agreements" (2002) 15:1 Leiden Journal of International Law 1 at 33-50.

284 Jessica F. Green, “Order out of Chaos: Public and Private Rules for Managing Carbon” (2013) 13:2 Global Environmental Politics 1 (arguing that the rules for CDM developed by the UNFCCC COP have been embedded in the private standards developed for voluntary carbon markets). See also Abbott, supra note 158 at 587. Jodoin \& Mason-Case, supra note 162 at 272-274.

${ }_{287}$ Decision 2/CP.17, paras 63-73. 
Warsaw Framework for REDD+ in $2013,{ }^{288}$ the UNFCCC COP has adopted a series of decisions that provide the core modalities and requirements for the pursuit of jurisdictional REDD+ activities in developing countries. To be sure, the construction and implementation of these legal norms has been influenced by developments and processes emanating from other sites of law at the international, transnational, and national levels. ${ }^{289}$ All the same, the UNFCCC COP has served as a venue in which legal norms for jurisdictional REDD+ activities have received the endorsement of states through a formalized process in a multilateral setting. As such, a wide range of actors in other sites of law have viewed the decisions of the UNFCCC as providing an authoritative set of international legal norms for the pursuit of jurisdictional REDD+ activities. ${ }^{290}$

\subsubsection{The Rights of Indigenous Peoples and Local Communities in UNFCCC Decision-Making on REDD+}

Although Indigenous Peoples formed an officially recognized caucus within the UNFCCC, the rights of Indigenous Peoples were largely absent from the negotiations and decisions of the UNFCCC COP until the second half of the 2000 s. $^{291}$ The only references to rights in the UNFCCC itself are to the rights of states to "exploit their own resources pursuant to their own environmental and developmental policies" and to "promote sustainable development." ${ }^{292}$ In particular, the rules and guidance adopted for the implementation of CDM projects under the Kyoto Protocol do not include any references to human rights standards. ${ }^{293}$ Numerous CDM projects, especially large hydro-electric projects, have thus been criticized for encroaching upon the rights of Indigenous Peoples and local communities. ${ }^{294}$ In fact, the deficient manner

288 CP.19.

289 See, e.g., Reinecke et al., supra note 251 (discussing the role and influence of the REDD+ Partnership in relation to the UNFCCC).

290 Interview 8 at 5; Interview 21 at 1; Interview 76 at 4 ; Interview 79 at 15 .

291 Lavanya Rajamani, "The Increasing Currency and Relevance of Rights-Based Perspectives in the International Negotiations on Climate Change" (2010) 22:3 Journal of Environmental Law 391 at 394 .

292 UNFCCC, preamble and art. 3.4.

293 For instance, neither Decision 17/CP.7, which provides the modalities and principles for the CDM, nor the CDM Executive Board, "Clean Development Mechanism Validation and Verification Manual” (Version o1.2), available at: https://cdm.unfccc.int/Reference/Standar ds/accr_mano1_2.pdf (accessed 16 September 2014) include any references to rights, Indigenous Peoples, or local communities. 
in which the UNFCCC's CDM regime addressed human rights issues prompted the development of private certification programs, such as the CDM Gold Standard, that include standards that recognize and aim to protect the rights of Indigenous Peoples and local communities. ${ }^{295}$ While the initial discussions of REDD+ were no exception to the general neglect of human rights issues that characterized the UNFCCC until the second half of the 2000s, Indigenous and community rights eventually became an important aspect of the UNFCCC's decision-making on REDD+. ${ }^{296}$

The Cancun Agreements, adopted by the UNFCC COP in December 2010, served as the vehicle for the first major decision on REDD+ within the UNFCCC. On the whole, the Cancun Agreements offered unprecedented levels of recognition of the linkages between human rights and climate change. ${ }^{297}$ The preamble to the Cancun Agreements most notably emphasizes that "Parties should, in all climate change-related actions, fully respect human rights." ${ }^{2} 9^{8}$ As far REDD+ is concerned, the Cancun Agreements specify that a national REDD+ strategy must address "drivers of deforestation and forest degradation, land tenure issues, forest governance issues, gender considerations and [environmental and social safeguards]" in a manner that ensures "the full and effective participation of relevant stakeholders, inter alia, indigenous peoples and local communities." ${ }^{299}$ Furthermore, the Cancun Agreements provide that the implementation of REDD+ should "promote" and "support" a set of social and environmental safeguards, ${ }^{300}$ including the following two safeguards that are relevant to the rights of Indigenous Peoples and local communities:

(c) Respect for the knowledge and rights of indigenous peoples and members of local communities, by taking into account relevant international obligations, national circumstances and laws, and noting that the United Nations General Assembly has adopted the United Nations Declaration on the Rights of Indigenous Peoples;

Gold Standard Foundation, "The Gold Standard Principles," available at: www.goldstandard .org/wp-content/uploads/2013/08/The-Gold-Standard-Principles-FINAL-270513.pdf (accessed 16 September 2014), at Indicator 1.1: "The project shall assess the risk of potential harmful impacts against a series of safeguarding principles on human rights, labour standards, environmental protection and anti-corruption. These safeguarding principles are derived from the UNDP MDG Carbon Facility, UN Millennium Development Goals and international conventions. Projects shall identify potential negative impacts based on these safeguarding principles and avoid, mitigate, or repair them.”

296 Jodoin, supra note 17 at $166-170$.

297 See Edward Cameron \& Marc Limon, "Restoring the Climate by Realizing Rights: The Role of the International Human Rights System” (2012) 21:3 Review of European Community \& International Environmental Law 204.

${ }_{298}$ Decision 1/CP.16, para. 8. ${ }^{299}$ Ibid, para. 72. $300 \quad$ Ibid, para. 69. 
(d) The full and effective participation of relevant stakeholders, in particular, indigenous peoples and local communities in [REDD+ activities]..$^{301}$

In addition, the Cancun Agreements also include a safeguard that aims to ensure that REDD+ activities serve, among other purposes, to "enhance other social and environmental benefits." This safeguard includes a footnote that indicates these purposes are to be achieved "[t]aking into account the need for sustainable livelihoods of indigenous peoples and local communities and their interdependence on forests in most countries, reflected in the United Nations Declaration on the Rights of Indigenous Peoples, as well as the International Mother Earth Day." ${ }^{\circ 02}$ Finally, it is worth noting that the fourth element of a developing country's readiness for jurisdictional REDD+ consists of the development of an information system for reporting on the way that these and other environmental and social safeguards are "being addressed and respected" in REDD+ activities "while respecting sovereignty." 303

Decisions subsequently adopted by the UNFCCC COP have further developed the safeguards regime set out in Cancun and addressed the related issue of incentivizing the provision of "non-carbon benefits" such as poverty reduction. As part of the Durban Platform adopted in December 2011, the UNFCCC COP specified that safeguard information systems must be implemented at the national level for all REDD+ activities "regardless of the source or type of financing"304 and through a "country-driven approach" that ultimately provides "transparent and consistent information that is accessible by all relevant stakeholders and updated on a regular basis." ${ }^{05}$ In the Warsaw Package for REDD+, adopted in November 2013, the UNFCCC COP established that developing countries have to provide periodical summaries of this information to the COP through national communications or some other channel, and on a web platform, on a voluntary basis. ${ }^{306}$ Most significantly, the Warsaw Package provided that developing countries seeking to obtain and receive results-based payments for REDD+ activities are obliged to "provide the most recent summary of information on how all of the safeguards [...] have been addressed and respected before they can receive results-based payments." ${ }^{\circ 07}$ Finally, during

301 Ibid, Annex I, para. 2 (c) and (d). $3^{302}$ Ibid at para. 2 (e).

303 Decision 1/CP.16, para. 71(d). 304 Decision 2/CP.17, para. 63.

305 Decision 12/CP.17, para. 2.

306 Decision 12/CP.19, "The timing and the frequency of presentations of the summary of information on how all the safeguards referred to in decision 1/CP.16, appendix I, are being addressed and respected" UN Doc. FCCC/CP/2013/10/Add.1 (31 January 2014).

307 Decision 9/CP.19, "Work programme on results-based finance to progress the full implementation of the activities referred to in decision 1/CP.16, paragraph 70" UN Doc. FCCC/ CP/2013/10/Add.1 (31 January 2014) at para. 4. 
the Paris Climate Conference held in December 2015, the UNFCCC COP adopted two decisions on REDD+ that relate to Indigenous and community rights. It reaffirmed the importance of incentivizing non-carbon benefits associated with the pursuit of REDD+ and decided that developing countries should be able to seek and obtain support for the integration of such benefits into their jurisdictional REDD+ activities. ${ }^{308}$ The UNFCC COP also reiterated that developing country governments should provide information on how social and environmental safeguards are being addressed and respected "in a way that ensures transparency, consistency, comprehensiveness and effectiveness," and encouraged them to include information on how each safeguard has been defined, addressed, and respected in the context of national circumstances. ${ }^{309}$

UNFCCC decision-making on the implementation of jurisdictional REDD+ activities has directly and indirectly addressed several types of participatory and substantive rights held by Indigenous Peoples and local communities. A few caveats are worth mentioning, however. With respect to the rights of Indigenous Peoples, the safeguards adopted in Cancun do not specifically refer to the right to free, prior, and informed consent and only "note" the adoption of the UN Declaration of the Rights of Indigenous Peoples. ${ }^{310}$ With respect to the rights of local communities, the use of the term "members of local communities" suggests that these communities do not hold the sort of sui generis collective rights held by Indigenous Peoples under international law. ${ }^{31}$ More broadly, the UNFCCC safeguards regime for REDD+ is built on the voluntary participation of developing countries and its application is not subject to an independent mechanism. ${ }^{312}$ As a result, IPOs and NGOs have shifted much of their focus to monitoring whether and to what extent developing countries are establishing safeguards information systems and effectively respecting the rights of Indigenous Peoples and local communities as part of the pursuit of jurisdictional REDD+. ${ }^{313}$

308 Decision 18/CP.21, "Methodological issues related to non-carbon benefits resulting from the implementation of the activities referred to in decision 1/CP.16, paragraph 70" UN Doc. FCCC/CP/2015/10/Add.3 (29 January 2016).

309 Decision 17/CP.21, "Further guidance on ensuring transparency, consistency, comprehensiveness and effectiveness when informing on how all the safeguards referred to in decision $\mathrm{l} /$ CP.16, appendix I, are being addressed and respected" UN Doc. FCCC/CP/2015/10/Add.3 (29 January 2016) at paras 3 and 5 .

310 The use of the term "note" to refer to an international instrument makes it clear that the instrument in question does not have any autonomous formal legal standing within the UNFCCC. See French \& Rajamani, supra note 280 at 446 (discussing the use of this term with respect to the adoption of the Copenhagen Accord.)

311 Gilbert \& Doyle, supra note 60. $\quad 312$ Jodoin, supra note 17 at 170-171.

313 In early 2013, IPOs and NGOs formed the REDD+ Safeguards Working Group. Based at the Ateneo School of Government in the Philippines and bringing together more than thirty 


\subsection{INDIGENOUS AND COMMUNITY RIGHTS \\ IN THE WORLD BANK FCPF}

\subsubsection{The World Bank FCPF in the Transnational Legal Process for REDD+}

Launched at the 13th session of the UNCCC in December 2007 and operational since June 2008 , the FCPF is a global partnership program of the World Bank. ${ }^{314}$ The FCPF was created to achieve four principal aims: (1) the provision of financial and technical assistance to build the capacity of developing countries to achieve emissions reductions through jurisdictional REDD+ activities; (2) the piloting of performance-based payments for REDD+ activities; (3) experimentation with approaches for sustaining or enhancing local livelihoods and biodiversity conservation through REDD+ activities; and (4) the dissemination of knowledge developed through the FCPF and its experience with supporting REDD+ readiness and jurisdictional activities. ${ }^{315}$ The FCPF comprises two funds for which the World Bank serves as trustee and provides a secretariat: a Readiness Fund that supports developing country capacity-building and preparedness for REDD+ activities and a Carbon Fund to test eventual performance-based payments for emissions reductions generated through REDD+ activities. ${ }^{316}$

As a mechanism for the delivery of finance and capacity-building, the FCPF has been criticized for its ineffectiveness, most notably because of the slow process for the disbursal of funds. ${ }^{317}$ As of June 2016, more than eight years after its launch, thirty-eight countries have managed to sign grant agreements to receive readiness support from FCPF and only thirteen countries have made enough progress in their readiness efforts to be in a position to apply for

NGOs from the around the world, it seeks "to ensure effective implementation of safeguards and the achievement of benefits for communities, climate and biodiversity through the global REDD+ mechanism" (REDD+ Safeguards Working Group, "What We Do," available at: http://reddplussafeguards.com?page_id=103 (accessed 8 January 2014)).

314 FCPF, "Forest Carbon Partnership Facility. Information Memorandum" (18 June 2008), available at www.forestcarbonpartnership.org/sites/forestcarbonpartnership.org/files/FCPF_ Info_Memo_o6-13-08.pdf at 11.

315 FCPF Charter, supra note 191 at Section 2.1.

316 The FCPF currently has forty-seven partner countries in Africa, Asia, Latin America, and the Caribbean as well as seventeen developed countries, private sector, and NGO donors and approximately 1.057 billion US dollars have been pledged to the trust funds under its management. FCPF, "About FCPF," available at: www.forestcarbonpartnership.org/aboutfcpf-o (accessed 5 May 2016).

317 Independent Evaluation Group, The Forest Carbon Partnership Facility: Global Program Review (August 2012), available at: https://ieg.worldbankgroup.org/Data/reports/fcpf_gpr.pdf (accessed 22 September 2014) at 11. 
funding from the Carbon Fund..$^{38}$ On the other hand, the FCPF has emerged as a central international site of law for jurisdictional REDD+ in two respects. First, the set of rules and policies that govern the delivery of finance within the World Bank, ${ }^{319}$ especially those relating to social and environmental safeguards, have not only applied to the jurisdictional REDD+ readiness efforts of FCPF developing country partners, but have also influenced the design of other multilateral and bilateral mechanisms for REDD+. ${ }^{320}$ Second, the FCPF has made significant contributions to the organization, development, and dissemination of knowledge, methodologies, and tools for the implementation of jurisdictional REDD+ activities in developing countries. ${ }^{321}$

\subsubsection{The Rights of Indigenous Peoples and Local Communities in the World Bank FCPF}

The World Bank has traditionally resisted the notion that human rights obligations and principles are applicable to its work based on the notion that political considerations are excluded from its mandate as a multilateral agency focused on economic development. ${ }^{322}$ Unlike many other multilateral and bilateral aid agencies, the World Bank does not have a standalone policy on human rights, nor has it adopted a rights-based approach to development. To the extent that human rights issues are incorporated into the World Bank's programming, they tend to be conceived in instrumental terms as "a means towards achieving other objectives such as economic

${ }_{318}$ FCPF, "FCPF Dashboard: Revised March 31, 2016," available at: www.forestcarbonpartner ship.org/sites/fcp/files/2016/May/PC21\%2。FCPF\%2oReadiness\%2oProgress_MASTERec.pdf (accessed 6 May 2016).

319 On the contribution of the World Bank's Operational Policies to international law-making, see, Benedict Kingsbury, "Operational Policies of International Institutions as Part of the Law-Making Process: The World Bank and Indigenous Peoples" in Guy S. Goodwin-Gill \& Stefan Talmon (eds.), The Reality of International Law: Essays in Honour of Ian Brownlie (Oxford: Clarendon Press, 1999) 323.

320 Indeed, other international organizations, such as the UNDP, have applied to serve as delivery partners under the FCPF readiness mechanism and have had to develop safeguards policies and procedures that are broadly equivalent with those of the World Bank.

321 A formal evaluation of the FCPF most notably concluded that "the FCPF has been very effective in defining what REDD readiness means, in creating knowledge and disseminating lessons, in opening up a space for dialogue on REDD between governments and civil society, and in raising awareness globally and in countries about REDD" (Independent Evaluation Group, supra note 317 at 23). See also NORAD, supra note 423 at 432 (concluding that "the FCPF has played a significant role in contributing to the establishment of global standards for REDD+.")

322 Galit A. Sarfaty, "Why Culture Matters in International Institutions: The Marginality of Human Rights at the World Bank" (2009) 103 American 647 at 657-649. 
development." ${ }^{23}$ Human rights concerns are specifically addressed at the World Bank through the application of safeguards that aim to prevent, mitigate, and address the adverse environmental and social impacts and risks of the Bank-financed projects. ${ }^{32}$ These safeguards form part of the Operational Policies and Procedures that serve to guide the work of the Bank's staff. They are also frequently incorporated into the loan agreements that the Bank signs with borrower countries as well as the instruments that govern the mechanisms and trust funds overseen by the Bank. ${ }^{325}$ Their application is monitored by the Inspection Panel, a permanent quasi-judicial body that considers complaints made by groups affected by Bankfinanced projects. ${ }^{326}$

The FCPF Charter clearly specifies that the World Bank's Operational Policies and Procedures apply to the FCPF"s activities, "taking into account the need for effective participation of Forest-Dependent Indigenous Peoples and Forest Dwellers in decisions that may affect them, respecting their rights under national law and applicable international obligations." ${ }^{27}$ As such, both the jurisdictional readiness efforts of developing countries that are funded through the FCPF Readiness Mechanism and the jurisdictional REDD+ activities and transactions that may be financed by the FCPF Carbon Fund must comply with the World Bank's set of social and environmental

323 Galit A. Sarfaty, Values in Translation: Human Rights and the Culture of the World Bank (Stanford, CA: Stanford University Press, 2012) at 13.

324 This safeguards regime was first adopted in the 1980 in response to a decades-long campaign led by NGOs around the significant and harmful social and environmental impacts of Bankfinanced projects in developing countries. See generally Jonathan Fox \& L. David Brown (eds.), The Struggle for Accountability: The World Bank, NGOs and Grassroots Movements (Cambridge, MA: MIT Press, 1998).

325 Laurence Boisson de Chazournes, "Policy Guidance and Compliance: The World Bank Operational Standards" in Dinah Shelton, (ed.), Commitment and Compliance: The Role of Non-Binding Norms in the International Legal System (Oxford, UK: Oxford University Press, 2000) 281 .

326 If the Inspection Panel decides that a complaint falls within the scope of its jurisdiction and that all other remedies have been exhausted, it may launch an investigation and issue a report to establish whether a project has complied or not with applicable policies and procedures and whether it has resulted in harm to the complainants. In carrying out its work, an Inspection Panel can reach findings that publicize particular instances of noncompliance with the operational standards and can issue recommendations on steps to remedy such instances. The World Bank's management team then prepares a response or action plan that sets out the remedial measures that it intends to adopt to address the violations of the Operational Policies and their consequences. See International Bank for Reconstruction and Development, Accountability at the World Bank. The Inspection Panel at Fifteen Years (2009), available at: http://siteresources.worldbank.org/EXTINSPECTIONPANEL/Resour ces/380793-1254158345788/InspectionPanel2009.pdf (accessed 30 December 2013).

327 FCPF Charter, supra note 192 at Section 3.1(d). 
safeguards. ${ }^{328}$ In addition, other multilateral organizations such as the InterAmerican Development Bank (IADB) and the UNDP that act as delivery partners under the FCPF must "achieve substantial equivalence" to these Operational Policies and their associated procedures under what is known as the "Common Approach." 329

Five of these safeguards policies are especially relevant to the participatory and substantive rights of Indigenous Peoples and local communities in the context of FCPF. First, Operational Policy 4.10 on Indigenous Peoples (1) requires that the proponents of Bank-funded projects ensure the full and effective participation of Indigenous Peoples and carry out processes of free, prior, and informed consultation, (2) makes the delivery of Bank finance contingent on broad community support among affected Indigenous Peoples for the project, and (3) avoids or minimizes negative effects from the project for Indigenous communities. ${ }^{30}$ Second, Operational Policy 4.01 on Environmental Assessment mandates the consideration of social and environmental aspects in the design, management, and implementation of Bank-funded projects. ${ }^{331}$ Third, Operational Policy 4.11 on Physical and Cultural Resources aims to ensure that Bank-funded projects assist in preserving resources with archaeological, paleontological, historical, architectural, religious, aesthetic, or cultural significance. ${ }^{32}$ Fourth, Operational Policy 4.12 on Involuntary Resettlement aims to avoid or minimize the involuntary resettlement of persons and related impacts from Bank-funded projects. ${ }^{333}$ Finally,

328 Ibid.

329 FCPF, Common Approach to Environmental and Social Safeguards for Multiple Delivery Partners (9 August 2012), available at: www.forestcarbonpartnership.org/sites/forestcarbonpart nership.org/files/Documents/PDF/Aug2012/FCPF\% 2oReadiness\% 20Fund\% 20 Common\%2O Approach\%208-9-12.pdf (accessed 30 December 2013), at para. 3.

$33^{\circ}$ World Bank, "Operational Policy 4.10 - Indigenous Peoples," available at: http://web.world bank.org/WBSITE/EXTERNAL/PROJECTS/EXTPOLICIES/EXTOPMANUAL/o,,conte ntMDK:20553653 menuPK:4564185 pagePK:64709096 piPK:64709108 theSiteP K:502184,00.html (accessed 27 November 2014).

331 World Bank, “Operational Policy 4.01 - Environmental Assessment," available at: http://web .worldbank.org/WBSITE/EXTERNAL/PROJECTS/EXTPOLICIES/EXTOPMANUAL/o,, contentMDK:20064724 menuPK:4564185 pagePK:64709096 piPK:64709108 theSiteP K:502184,00.html (accessed 27 November 2014).

$33^{2}$ World Bank, "Operational Policy 4.11 - Physical Cultural Resources," available at: http://web .worldbank.org/WBSITE/EXTERNAL/PROJECTS/EXTPOLICIES/EXTOPMANUAL/o,, contentMDK:20970737 menuPK:4564185 pagePK:64709096 piPK:64709108 theSiteP K:502184,00.html (accessed 27 November 2014).

333 World Bank, "Operational Policy 4.12 - Involuntary Resettlement," available at: http://web .worldbank.org/WBSITE/EXTERNAL/PROJECTS/EXTPOLICIES/EXTOPMANUAL/o,, contentMDK:20064610 menuPK:4564185 pagePK:64709096 piPK:64709108 theSiteP K:502184,00.html (accessed 27 November 2014). 
Operational Policy 4.36 on Forests seeks to realize the potential of forests for poverty reduction and sustainable economic development and accords "preference to small-scale community-level management approaches where they best reduce poverty in a sustainable manner." 334

To the extent that these social and environmental safeguards were created for the delivery of actual projects rather than through a policy development process, their application to a country's REDD+ readiness phase is not necessarily straightforward. ${ }^{335}$ In order to ensure jurisdictional REDD+ readiness efforts funded through the FCPF pro-actively respect these safeguards, the FCPF has required participating developing countries to carry out a Strategic and Environmental Assessment (SESA) and produce an Environmental and Social Management Framework (ESMF) as an integral part of their process for applying for funding under the Readiness Mechanism. ${ }^{336}$ A SESA aims "to assess the broader strategic environmental and social impacts, including potential cumulative impacts, which may ensue from future REDD+ activities or projects, and to develop sound environmental and social policies and the necessary safeguards instruments that will apply to subsequent REDD+ investments and carbon finance transactions."337 In practical terms, a SESA involves a combination of diagnostic and consultative activities aimed at contributing to the development of a country's national REDD+ strategy. ${ }^{3} 8$ These are intended to ensure that social and environmental safeguards are integrated "at the earliest stage of decision making" and

334 World Bank, "Operational Policy 4.36 - Forests," available at: http://web.worldbank.org/W BSITE/EXTERNAL/PROJECTS/EXTPOLICIES/EXTOPMANUAL/o,, contentMD K:20064668 menuPK:4564185 pagePK:64709096 piPK:64709108 theSitePK:502184,oo.ht $\mathrm{ml}$ (accessed 27 November 2014). Interview 72 at 4 ; Interview 94 at 1.

336 Readiness Preparation Proposal Template Document, Version 6, (23 November 2011), available at: www.unredd.net/index.php?option $=$ com_docman\&task=doc_download\&gi $\mathrm{d}=6869$ \&Itemid $=53$ (accessed 30 December 2013), Annex 4.

337 FCPF, Forest Carbon Partnership Facility (FCPF) Readiness Fund Common Approach to Environmental and Social Safeguards for Multiple Delivery Partners, 9 June 2011, rev. 10 August 2011, para. 17 .

$33^{8}$ These activities include: new or existing diagnostic work to address "the drivers of deforestation and the key social and environmental issues associated with the drivers, [including] issues such as land tenure, sharing of benefits, access to resources, and the likely social and environmental impacts of REDD+ strategy options"; diagnostic work on the legal, policy and institutional aspects of REDD+ readiness; an assessment of existing capacities to address these issues; the integration of this diagnostic work and assessment in the development of national REDD+ policies; the development of risk mitigation and management frameworks for REDD+ policies and future activities; and engagement and consultations with stakeholders throughout the above steps as part of existing consultations for national REDD+ readiness (ibid at para. 20). 
that the strategy itself "reflects inputs from key stakeholder groups and addresses the main environmental and social issues identified." 339 In addition, a SESA should result in the adoption of an ESMF that serves as distinct output from a national REDD+ strategy and provides a "framework for managing and mitigating the potential environmental and social impacts and risks related to policy changes, investments and carbon finance transactions in the context of the future implementation of REDD+." 340

\subsection{INDIGENOUS AND COMMUNITY RIGHTS \\ IN THE UN-REDD PROGRAMME}

\subsubsection{The UN-REDD Programme and the Transnational Legal Process for REDD+}

The UN-REDD Programme is a collaborative initiative jointly established in June 2008 by the United Nations Development Programme (UNDP), the United Nations Environment Programme (UNEP), and the Food and Agriculture Organization (FAO). ${ }^{341}$ The central objective of the UN-REDD Programme is to "promote the elaboration and implementation of National REDD+ Strategies to achieve REDD+ readiness, including the transformation of land use and sustainable forest management and performance-based payments." 342 The UN-REDD Programme carries out two main sets of activities. It runs a series of "National Programmes" that provide direct financial and technical support to the jurisdictional REDD+ readiness efforts of developing countries. ${ }^{343}$ These programs focus on six key work areas: the development of MRV systems; national REDD+ governance; stakeholder engagement; multiple benefits; REDD+ finance and benefit-sharing; and the transformation of forestry and other relevant sectors. ${ }^{344}$ In addition, the UN-REDD Programme has a global program that seeks to elaborate and

339 Ibid at para. 19. $34^{\circ}$ Ibid.

341 UN-REDD Programme, “The UN-REDD Programme Strategy. 2011-2015," available at: www.unep.org/forests/Portals/142/docs/UN-REDD\%2oProgramme\%zoStrategy.pdf (accessed 28 November 2014) at 26-27.

342 Ibid at 6

343 As of June 2016, more than 281 million US dollars have been committed to the UN-REDD Programme, which currently supports national REDD+ readiness programs in 64 partner countries. See Multi-Partner Trust Fund Office, "UN REDD Programme Fund," available at: http://mptf.undp.org/factsheet/fund/CCFoo (accessed 5 May 2016); UN-REDD Programme, "Regions and Countries Overview" www.un-redd.org/Partner_Countries/tabi d/102663/Default.aspx (accessed 5 May 2016).

344 UN-REDD Programme Framework Document, supra note 193 at 10-11. 
disseminate common methodologies and approaches for operationalizing jurisdictional REDD+ based on the experience gained in the readiness efforts of developing countries and in line with the decisions of the UNFCCC COP. ${ }^{345}$

Unlike the FCPF, the UN-REDD Programme was able to launch and operationalize several national programs in developing countries in the early stages of the global rollout of REDD+ in 2009. ${ }^{346}$ However, the support and technical assistance provided by the UN-REDD Programme for jurisdictional REDD+ readiness efforts has been criticized for the tendency of international staff and consultants to impose their own set of goals and solutions rather than working with developing countries to generate country-driven approaches to the implementation of jurisdictional REDD+. ${ }^{347}$ The effectiveness of the UNREDD Programme's contributions to jurisdictional REDD+ readiness efforts has also been limited by the challenges involved in adapting its plans and activities to an evolving international conception of REDD+, fostering triagency collaboration, and coordinating its work with other multilateral and bilateral donors. ${ }^{34^{8}}$ While the results achieved by the UN-REDD Programme with respect to supporting the jurisdictional REDD+ readiness efforts of developing countries have generally been underwhelming, the UN-REDD Programme has played an important role in generating and spreading legal norms relating to the core elements of jurisdictional REDD+ readiness. ${ }^{349}$

\subsubsection{The Rights of Indigenous Peoples and Local Communities in the UN-REDD Programme}

In accordance with the United Nations' broader commitment to the integration of human rights in its development programming, ${ }^{35}$ the UN-REDD Programme has adopted a "rights-based approach" to its work. ${ }^{351}$ In the early stages of the development of the UN-REDD Programme, its activities

345 Ibid at 23-24. $346 \quad$ NORAD, supra note 423 at 471 and $475-476$.

347 Alain Fréchette et al., "External Evaluation of the United Nations Collaborative Programme on Reducing Emissions from Deforestation and Forest Degradation in Developing Countries (the UN-REDD Programme)" available at: www.unep.org/eou/Portals/52/Report s/UN-REDD\%2oEvaluation\%2oFinal\%20Report\%20July\%2O2014\%20\%28ENG\%29.pdf (accessed 28 November 2014) at 20-21.

$34^{8}$ Ibid. at 26-29; NORAD, supra note 423 at 468-469. 349 Ibid. at 473-474.

$35^{\circ}$ UNDP, The Human Rights-based Approach to Development Cooperation: Towards a Common Understanding among the UN Agencies (2003), available at: www.undp.org/govern ance/docs/HR_Guides_CommonUnderstanding.pdf (accessed on 28 November 2014).

351 Fréchette et al., supra note 347 at 62. 
were guided by a set of social and environmental principles that reflected its "responsibility to apply a human rights based approach, uphold UN conventions, treaties and declarations, and [...] apply the UN agencies' policies and procedures." ${ }^{52}$ The principles most notably included the following criteria: "a) All relevant stakeholder groups are identified and enabled to participate in a meaningful and effective manner; b) Special attention is given to the most vulnerable groups and the free, prior and informed consent of indigenous peoples." 353 Accordingly, the UN-REDD Programme therefore provides as follows:

To be eligible for funding, activities at both the national and international level should support the participation of Indigenous Peoples, other forest dependent communities and civil society in national readiness and REDD+ processes in accordance with: (1) the UN-REDD Programme Operational Guidance and social standards; (2) negotiated REDD+ safeguards arrangements; and (3) a country's commitment to strengthen the national application of existing rights, conventions and declarations. ${ }^{354}$

Although there was some interest, especially among UNDP staff members, in the UN-REDD Programme developing or adopting a set of mandatory standards and safeguards to govern its activities, this approach was not supported by the FAO and the UNEP. 355 Instead, since March 2012, the activities of the UN-REDD Programme have been governed by a nonbinding set of Social and Environmental Principles and Criteria (SEPC) that were developed through extensive consultations with international experts, development country governments, and stakeholders. ${ }^{35}$ The SEPC are meant to apply to the design, planning, implementation, and monitoring of national REDD+ activities supported by the UN-REDD Programme as well as serve as inspiration for the development of REDD+ safeguards systems by developing country governments participating in a UN-REDD National Programme. ${ }^{357}$ The principles and criteria incorporate commitments drawn from a range of international instruments as well as the

UN-REDD Programme, "Update on Social and Environmental Principles" UN-REDD Programme 5th Policy Board Meeting, November 2010, UN Doc. UNREDD/PBS/2010/12, available at: www.unredd.net/index.php?option=com_docman\&task=doc_download\&gi $\mathrm{d}=3554 \&$ Itemid $=53$ (accessed 28 November 2014) at 2. Ibid at 5. 354 UN-REDD Programme Framework Document, supra note 193 at 12. Interview 66 at $5-6$.

UN-REDD Programme, "Social and Environmental Principles and Criteria" UN-REDD Programme Eighth Policy Board Meeting (25-26 March 2012, Asunción, Paraguay), available at: www.unredd.net/index.php?option=com_docman\&task=doc_download\&gid=6754\&Ite mid $=53$ (accessed 28 November 2014) at 3 . 
interpretative guidance provided by their associated bodies. ${ }^{35}$ The SEPC includes seven principles, and twenty-four associated criteria that lay out associated conditions that the activities of the UN-REDD Programme must meet to respect or fulfil these principles. Some of the principles and criteria most relevant to the participatory and substantive rights of Indigenous Peoples and local communities include the following:

- "Principle 1 - Apply norms of democratic governance, as reflected in national commitments and Multilateral Agreements" and the related "Criterion 4 - Ensure the full and effective participation of relevant stakeholders in design, planning and implementation of REDD+ activities, with particular attention to indigenous peoples, local communities and other vulnerable and marginalized groups";

- "Principle 2 - Respect and protect stakeholder rights in accordance with international obligations" and the related "Criterion 7 - Respect and promote the recognition and exercise of the rights of indigenous peoples, local communities and other vulnerable and marginalized groups to land, territories and resources, including carbon"; and

- "Principle 3 - Promote sustainable livelihoods and poverty reduction" and the related "Criterion 12 - Ensure equitable, non-discriminatory and transparent benefit sharing among relevant stakeholders with special attention to the most vulnerable and marginalized groups."

In order to guide UN-REDD staff members, national government civil servants, and stakeholders in the application and monitoring of a government's SEPC, the UN-REDD Programme has developed a Benefit and Risks Tool (BERT). 359 The BERT sets out questions that may guide users in the identification of social and environmental risks and opportunities throughout the design, implementation, and monitoring of a UN-REDD National Programme. The BERT includes several questions and related guidance materials from third parties that provide opportunities to highlight and consider the importance of respecting the participatory and substantive rights of Indigenous Peoples and

$35^{8}$ This includes: the UNFCCC, the UN Convention on Biological Diversity, the Non-Legally Binding Instrument on all Types of Forest, the Convention on the Elimination of All Forms of Discrimination against Women, the International Labour Organization Convention 169, the United Nations Convention Against Corruption, the United Nations Declaration on the Rights of Indigenous Peoples, the United Nations Convention on the Elimination of All Forms of Racial Discrimination, and the Millennium Development Goals.

359 UN-REDD Programme, "Draft Social and Environmental Principles and Criteria - Benefit and Risks Tool Using the SEPC" (2013), available at: www.unredd.net/index.php?option= com_docman\&task=doc_download \&gid=6380\&Itemid=53 (accessed 28 November 2014). 
local communities in REDD+ activities. ${ }^{360}$ It should be emphasized that the BERT is a new tool that is still being tested and refined by the UN-REDD Programme, in consultation with country partners and stakeholders, and its effectiveness in monitoring adherence to the SEPC is an open question. ${ }^{361}$

In addition, the UN-REDD Programme has developed and released several other tools and guidelines that outline the normative, policy, and operational standards and frameworks that can guide jurisdictional REDD+ readiness activities with respect to the participation and rights of Indigenous Peoples and local communities. ${ }^{362}$ Three such efforts are particularly worth mentioning. First, the UN-REDD Programme has emerged "as one of the primary instigators and advocates of FPIC in REDD+." ${ }^{63}$ From 2010 to 2013, the UNREDD Programme organized an extensive series of regional workshops in Asia, Africa, and Latin America in which multiple stakeholders (developing country governments, IPOs, CSOs, and aid agencies) discussed the challenges and opportunities involved in operationalizing the right to free, prior, and informed consent in the context of REDD+. ${ }^{364}$ These consultations have led to the preparation and release of a set of guidelines that define the elements of free, prior, and informed consent and provide a concrete operational framework for respecting this principle in the context of REDD+ programs. ${ }^{365}$ In accordance with the feedback received from IPOs as well as international lawyers within the UN system, ${ }^{366}$ the guidelines clearly differentiate between the obligations owed to Indigenous Peoples and those owed to forest-dependent communities, recognizing that FPIC primarily applies to the former and only applies to the latter in limited circumstances. ${ }^{367}$

360 For instance, under Principle 2 - Criterion 7 , the BERT requires consideration of whether there are "existing policies and measures in place that help to respect and promote the recognition and exercise of equitable land tenure and carbon rights by indigenous peoples and local communities," whether "the REDD+ programme include[s] specific actions to respect and promote the recognition and exercise of equitable land tenure and carbon rights by indigenous peoples and local communities," and whether "the REDD+ programme ha[s] provisions to improve access to legal systems for indigenous peoples and local communities, where necessary" (Ibid, Principle 2, Criterion 7, questions 1, 2, and 3).

${ }_{361}$ Interview 66 at 6-8. $\quad{ }_{362}$ Fréchette et al., supra note 347 at 62-64. $\quad 363 \quad$ Ibid at 63.

364 Interview 66 at $16-17$.

365 UN-REDD Programme, "Guidelines on Free, Prior and Informed Consent" (January 2013), available at: www.unredd.net/index.php?option=com_docman\&task=doc_download\&gi $\mathrm{d}=8717 \&$ Itemid $=53$ (accessed 7 January 2014).

366 Interview 66 at 22.

367 Ibid at 11: "Consistent with international law, States are required to recognize and carry out their duties and obligations to give effect to the requirement of FPIC as applicable to indigenous peoples; and recognizing the right of forest-dependent communities to effectively participate in the governance of their nations, at a minimum States are required to consult forest-dependent communities in good faith regarding matters that affect them 
Second, in collaboration with the FCPF, the UN-REDD Programme has produced joint guidelines for stakeholder engagement for jurisdictional REDD+ readiness that set out a step-by-step guide for undertaking consultations, provide a comprehensive overview of relevant international policies on Indigenous peoples and other forest-dependent communities, and offer guidance on how countries should reconcile inconsistent policy commitments between the approach adopted by the UN-REDD Programme and the FCPF ${ }^{368}$ For the purposes of understanding its implications for the recognition and protection of the rights of Indigenous Peoples and local communities, the following passage addressing the initiation of participatory processes for REDD+ is worth mentioning:

Special emphasis should be given to the issues of land tenure, resource-use rights and property rights because in many tropical forest countries these are unclear as indigenous peoples' customary/ancestral rights may not necessarily be codified in, or consistent with, national laws. Another important issue to consider for indigenous peoples and other forest dwellers is that of livelihoods. Thus clarifying and ensuring their rights to land and carbon assets, including community (collective) rights, in conjunction with the broader array of indigenous peoples' rights as defined in applicable international obligations, and introducing better access to and control over the resources will be critical priorities for REDD+ formulation and implementation. ${ }^{369}$

with a view to agreement. Appreciating that international law, jurisprudence and State practice is still in its infancy with respect to expressly recognizing and requiring an affirmative obligation to secure FPIC from all forest-dependent communities, a blanket application of FPIC is not required for all forest-dependent communities. That said, the Guidelines soberly recognize that, in many circumstances, REDD+ activities may impact forest-dependent communities, often similarly as indigenous peoples, and that the circumstances of certain forest-dependent communities may rise to a threshold such that it should be seen as a requirement of States to secure FPIC when an activity may affect the communities' rights and interests. [...] As such, States should evaluate the circumstances and nature of the forest-dependent community in question, on a case by case basis, through among others a rights-based analysis, and secure FPIC from communities that share common characteristics with indigenous peoples and whose underlying substantive rights are significantly implicated." [Emphasis in original].

UN-REDD Programme, "Guidelines on Stakeholder Engagement," available at: www.unredd.org/Stakeholder_Engagement/Guidelines_On_Stakeholder_Engagement/tabid/55619/ Default.aspx (accessed 28 November 2014). The main difference between these two approaches is that the UN-REDD Programme is committed to a rights-based approach (as reflected in its social and environmental principles and criteria) and most notably recognizes and promotes the right of Indigenous Peoples to free, prior, and informed consent. By contrast, the FCPF is governed by a risk-based approach (as reflecting in its mandatory safeguard policies) and only recognizes the rights of Indigenous Peoples to free, prior, and informed consultations.

369 R-PP Template Document Annex B, at 10. 
Third, the UN-REDD Programme has developed a Country Approach to Safeguards Tool (CAST) that enables developing countries to design, plan, and implement a process for the elaboration of social and environmental safeguards for REDD+ as well as the creation of a safeguard information system. ${ }^{370}$ CAST provides a methodology for implementing the Cancun Agreements' requirement with respect to social and environmental safeguards for REDD+ and is thus meant to serve all developing countries carrying out jurisdictional REDD+ readiness efforts, whether or not they are partners of the UN-REDD Programme. ${ }^{371}$ CAST is organized as a series of questions that pertain to the different stages in the establishment of social and environmental safeguards for REDD+, and provides a range of sources and guidance materials for, among other things, implementing safeguards information systems or leading stakeholder engagement processes. ${ }^{372}$

\subsection{INDIGENOUS AND COMMUNITY RIGHTS IN THE CCBA}

\subsubsection{The CCBA and the Transnational Legal Process for REDD+}

The CCBA is a nongovernmental standard-setting program that was established in 2003 by Conservation International, CARE International, the Rainforest Alliance, The Nature Conservancy, and the Wildlife Conservation Society with a view to fostering "land management activities that credibly mitigate global climate change, improve the wellbeing and reduce the poverty of local communities, and conserve biodiversity." 373 From 2003 to 2005 , the CCBA facilitated the drafting of the Climate, Community and Biodiversity (CCB) Standards in order to promote "development of, and investment in, site-based projects that deliver credible and significant climate, community and biodiversity benefits in an integrated, sustainable manner." ${ }^{374}$ The CCB Standards were subsequently revised in a second edition launched in

UN-REDD Programme, "Country Approach to Safeguards Tool (CAST). User's Guide" available at: www.unredd.net/index.php?option=com_docman\&task=doc_download\&gi $\mathrm{d}=12996 \&$ Itemid $=53$ (accessed 28 November 2014).

Ibid at $1-2$.

UN-REDD Programme, "Country Approach to Safeguards Tool (CAST)" available at: www .unredd.net/index.php?option=com_docman\&task=doc_download\&gid $=12997 \&$ Itemid $=53$ (accessed 28 November 2014).

73 CCBA, Rules for the Use of the Climate, Community $\&$ Biodiversity Standards, 2013, available at: https://s3.amazonaws.com/CCBA/Third_Edition/Rules_for_the_Use_of_the_CCB_Sta ndards_December_2013.pdf (accessed 24 September 2014) at 1.

Ibid. at 1. 
December 2008. ${ }^{375}$ By 2012, the CCB Standards had become the leading multiple-benefit standard for land-based climate mitigation projects and their use has become standard practice for project-based REDD+ activities. ${ }^{376}$ Since the release of the second edition in 2008, the CCBA had received substantial feedback from project developers and other stakeholders regarding ways to improve and strengthen the CCB Standards. ${ }^{377}$ In response, the CCBA launched a revision process in 2012 to develop a third edition with the specific objective of fostering "market interest and confidence in carbon credits from smallholder- and community-led projects." $37^{8}$ The drafting of the third edition of the CCB Standards from April 2012 to December 2013 employed a participatory and transparent process that entailed the creation of a multi-stakeholder steering committee, a stakeholder mapping exercise, and public exchanges with interested parties. ${ }^{379}$ This time around, the composition of the CCB Standards Committee was expanded to include a second Indigenous member as well as two representatives of non-Indigenous communities. ${ }^{30}$ Moreover, the greater uptake and prominence of the CCB Standards at this point in time meant that the CCBA received much more significant feedback from a broader number and variety of interested parties. ${ }^{381}$

CCBA, Guidance for the Use of CCB Standards, available at: https://sz.amazonaws.com/CC BA/Guidance_for_the_Use_of_the_CCB_Standards_May_2013.pdf (accessed 24 September 2014) at 1.

376 Molly Peters-Stanley, Katherine Hamilton \& Daphne Yin, Leveraging the Landscape. State of the Forest Carbon Markets 2012 (Washington, DC: Ecosystem Marketplace, 2012) at 31. CCBA, "Terms of reference, procedures and work plan for revision of CCB Standards including modifications that support smallholder- and community-led projects" (16 November 2012), available at: https://sz.amazonaws.com/CCBA/Upload/Revision+and+small/TOR+and+work plan+for+CCB+Standards+revision+11-19-12.pdf (accessed 24 September 2014) at 3. Ibid at 4 .

379 The second revision included a supplementary element: the establishment of a mechanism for resolving potential complaints regarding the process by which the CCB Standards would be revised (ibid at 5-6).

$3^{80}$ CCBA, "CCB Standards 'Standards Committee' Composition” (15 January 2013), available at: https://sz.amazonaws.com/CCBA/Upload/Revision+and+small/CCB+Standards+Com mittee+composition+02-04-13.pdf (accessed 1 October 2014).

${ }^{81}$ See CCBA, "Compilation by principle of all comments on the Draft Third Edition of the CCB Standards of 22nd March 2013 received during the first 6o-day public comment period 22nd March to 31st May 2013" (26 July 2013), available at: https://sz.amazonaws.com/CCBA/ Upload/Revision+and+small/Second+Comment+Period $+\% 26+$ Rules/CCB+Standards+Th ird+Edition+response+to+comments+31st+July+2013.pdf (accessed 1 October 2014); CCBA, "Compilation by principle of all comments on the Draft Third Edition of the CCB Standards of 31st July 2013 received during the second 6o-day public comment period ist August to 29th September 2013" (26 October 2013), available at: https://s3.amazonaws.com/CCBA/History_ of_the_Standards/CCB+Standards_Second+Public+Comment+Period_Response+to+Co mments.pdf (accessed i October 2014). 
Along with the VCS, the CCBA has emerged as an important transnational site of law for the pursuit of project-based REDD+ activities. ${ }^{382}$ While the CCB Standards do not lead to the issuance of carbon credits, ${ }^{383}$ verification and validation that a REDD+ project has met the CCB Standards will enable that project to tag any carbon credits issued through a carbon accounting standard such as the VCS AFOLU with a CCB label. The CCB Standards thus offer project developers with rules and guidance for the design and implementation of land-based climate mitigation projects "that simultaneously reduce or remove greenhouse gas emissions and generate positive impacts for local communities and the local environment" ${ }^{13}{ }^{8}$ and, moreover, provide an independent demonstration to potential donors or investors that projects have delivered additional net environmental and social benefits. ${ }^{385}$ As of June 2016, thirty-five REDD+ projects had been fully validated and verified under the CCB Standards, ten REDD+ projects are currently undergoing verification, and fifty-four REDD+ projects have been validated, but not yet verified. ${ }^{386}$

\subsubsection{The Rights of Indigenous Peoples and Local Communities in the CCBA}

While the first edition of the CCB Standards may have been perceived as inclined toward the environmental objectives of land-based carbon mitigation activities, the third edition of the CCB Standards can be seen as reflecting a sustained and comprehensive focus on human rights and social development. ${ }^{387}$ The third edition of the CCB Standards comprise seventeen required criteria that are divided into four sections covering general matters relating to the establishment of a project, its positive climate impacts, its benefits for communities, and its impacts for the preservation of biodiversity. It also includes three optional requirements relating to the provision of climate adaptation benefits and "exceptional" benefits for communities and biodiversity. When one of these optional requirements is met, a project can be tagged with gold level certification. ${ }^{38}$ both the VCS and the CCB Standards (Molly Peters-Stanley, Gloria Gonzalez \& Daphne Yin, Covering New Ground. State of the Forest Carbon Markets 2013 (Washington, DC: Ecosystem Marketplace), 2013 at xiv).

$3^{83}$ CCBA, Rules for the Use of the CCB Standards, supra note 372 at $3 . \quad 3^{84} \quad$ Ibid.

385 CCBA, CCB Standards Third Edition, 2013, available at: https://s3.amazonaws.com/CCBA/ Third_Edition/CCB_Standards_Third_Edition_December_2013.pdf at 7-8.

386 CCBA, "Projects," available at: www.climate-standards.org/category/projects/ (accessed 14 June 2016).

$3^{87}$ On the evolution of the CCB Standards, see Jodoin, supra note 17 at 175-181.

388 CCBA, supra note 385 at 13 . 
The third edition of the CCB Standards applies an expansive approach to the protection of the rights and interests of Indigenous Peoples and local communities. It is primarily concerned with the well-being of "communities" and "community groups." Communities are defined as "as all groups of peopleincluding Indigenous Peoples, mobile peoples and other local communities who derive income, livelihood or cultural values and other contributions to well-being from the Project Area at the start of the project and/or under the with-project scenario." ${ }^{89}$ Community groups are described "as sub-groups of Communities whose members derive similar income, livelihood and/or cultural values and other contributions to well-being from the Project Area and whose values are different from those of other groups; such as Indigenous Peoples, women, youth or other social, cultural and economic groups." 390 The CCB Standards also include consideration of groups known as "other stakeholders," defined as "all groups other than Communities who can potentially affect or be affected by the project activities and who may live within or outside the Project Zone." ${ }^{391}$

The CCB Standards incorporate Indigenous and community rights in four important ways. First, the CCB Standards include a criterion requiring the full and effective participation and consent of affected communities and stakeholders:

Communities and Other Stakeholders are involved in the project through full and effective participation, including access to information, consultation, participation in decision-making and implementation, and Free, Prior and Informed Consent (...). Timely and adequate information is accessible in a language and manner understood by the Communities and Other Stakeholders. Effective and timely consultations are conducted with all relevant stakeholders and participation is ensured, as appropriate, of those that want to be involved..$^{32}$

This criterion most notably includes specific and comprehensive indicators relating to participatory rights, including access to information, consultation, participation in decision-making, and grievance procedures. ${ }^{393}$ In addition, this criterion contains an indicator on anti-discrimination, and requires a description of "the measures needed and taken to ensure that the project proponent and all other entities involved in project design and implementation are not involved in or complicit in any form of discrimination or sexual harassment with respect to the project."394

$3^{89} \quad$ Ibid at fn $18 . \quad 39^{\circ} \quad$ Ibid at fn 19. $391 \quad$ Ibid at fn 20.

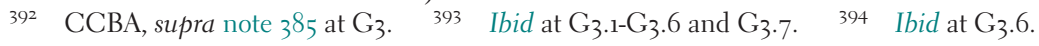


Second, the CCB Standards provide enhanced protections for the customary land and resource rights of local communities. They mandate that the free, prior, and informed consent of "relevant Property Rights Holders has been obtained at every stage of the project" 395 (from design to implementation), in line with the comprehensive guidance that is now included among its indicators. ${ }^{396}$ They also require that project developers ensure their project "respects and supports rights to lands, territories and resources, including the statutory and customary rights of Indigenous Peoples and others within Communities and Other Stakeholders." ${ }^{397}$ In particular, the CCB Standards require project developers to "[d]escribe and map statutory and customary tenure/use/access/management rights to lands, territories and resources in the Project Zone including individual and collective rights and including overlapping or conflicting rights," "describe measures needed and taken by the project to help to secure statutory rights," and "[d]emonstrate that all Property Rights are recognized, respected, and supported." ${ }^{398}$

Third, the CCB Standards require that projects generate "net positive impacts on the well-being" of affected communities. ${ }^{399}$ Project developers must therefore evaluate the direct and indirect benefits, costs, and risks of a project for communities living within the project area, carry out measures to mitigate any negative impacts, and demonstrate that the net well-being impacts of a project are positive for groups within affected communities. ${ }^{400}$ The CCB Standards also mandate that projects must "do no harm" to the well-being of other stakeholders. ${ }^{401}$ The evaluation of well-being in this context is explicitly restricted to compliance with statutory or customary rights. ${ }^{402}$ In addition, project developers seeking certification under the CCB Standards must develop and implement a monitoring plan to evaluate the project's impacts on the wellbeing of communities and stakeholders as well as the effectiveness of measures adopted to maintain or enhance community well-being. ${ }^{403}$

Finally, the CCB Standards include two optional criteria that further advance the rights and interests of local communities. The optional criterion in climate benefits mandates that projects identify and implement strategies to assist communities in adapting to the impacts of climate change. ${ }^{404}$ Most importantly, the third edition of the CCB Standards includes an optional criterion on exceptional community benefits that applies only to projects that are either led by communities or are explicitly aimed at reducing poverty. ${ }^{405}$ This criterion is focused on the equitable sharing of benefits with as

395 Ibid at G5. $\quad 396$ Ibid at $\mathrm{G}_{5.2} . \quad 397 \quad$ Ibid at $\mathrm{G}_{5} . \quad 39^{8} \quad$ Ibid at G5.1.

399 Ibid at $\mathrm{CM}_{2}$. ${ }^{00}$ Ibid at $\mathrm{CM}_{2.1}-\mathrm{CM}_{23}$. ${ }^{401}$ Ibid at $\mathrm{CM}_{3}$. ${ }^{402}$ Ibid at fn. 100.

403 Ibid at $\mathrm{CM}_{4 \cdot 1-2 .} \quad{ }^{404}$ Ibid at GL1. $\quad{ }_{405}$ Ibid at GL2. 
well as within communities. ${ }^{406}$ The indicators related to this criterion include a special focus on demonstrating net positive impacts, in terms of well-being and increased levels of participation in decision-making, for marginalized or vulnerable communities, marginalized or vulnerable members of communities, and women. $^{407}$

\subsection{INDIGENOUS AND COMMUNITY RIGHTS}

IN THE REDD+ SES

\subsubsection{The REDD+ SES and the Transnational Legal Process for REDD+}

The REDD+ Social and Environmental Safeguards (REDD+ SES) is a multistakeholder initiative launched in May 2009 to develop a set of voluntary social and environmental safeguards for government-led REDD+ programs and activities. ${ }^{408}$ The purpose of the REDD+ SES is to "support the design and implementation of REDD+ programs that respect the rights of Indigenous Peoples and local communities and generate significant social and biodiversity benefits."409 The development and application of the REDD+ SES is overseen by an international secretariat provided by the Community, Climate $\&$ Biodiversity Alliance (CCBA) and CARE International, with the support of the ProForest Initiative. ${ }^{410}$ A first version of the REDD+ SES was developed in 2009 and 2010 through an iterative process involving workshops and consultations bringing together representatives from governments participating in or contributing to REDD+ readiness efforts, international and non-governmental organizations, Indigenous Peoples and forest-dependent communities, and the private sector. ${ }^{411}$ A second version released in September 2012 drew on

406 Ibid at GL2: "Well-being benefits are shared equitably not only with the Smallholders/ Community Members but also among the Smallholders/Community Members, ensuring that equitable benefits also flow to more marginalized and/or vulnerable households and individuals within them."

407 Ibid at GL2.4 and GL2.5.

408 REDD+ SES, “About the REDD+ SES," available at: www.redd-standards.org (accessed 15 December 2013).

$4 \circ 9$ REDD+ SES, "REDD+ Social \& Environmental Standards” Version 2, 10 September 2012, available at: www.redd-standards.org (accessed 4 April 2016) at 3.

$4^{10}$ REDD+ SES, “Governance," available at: www.redd-standards.org/governance (accessed 4 April 2016).

$4^{111}$ REDD+ SES, “About the REDD+ SES," available at: www.redd-standards.org (accessed 4 April 2016). 
early experiences with the application of the REDD+ SES, the comments received from a range of stakeholders, and the guidance on safeguards provided by the UNFCCC. ${ }^{412}$ The proponents of the REDD+ SES argue that it offered added value due to three considerations: (1) the safeguards were developed through an inclusive multi-stakeholder process that has provided them with a high level of credibility; (2) they go beyond risk-mitigation to promote the multiple benefits achievable through REDD+; and (3) they provide a broad and flexible framework for meeting the requirements set by a wide range of standard-setting bodies for REDD+. ${ }^{413}$ The REDD+ SES has also served as an important site for developing and sharing insights on the interpretation and application of safeguards in the context of the pursuit of jurisdictional REDD+ readiness activities. ${ }^{414}$

The REDD+ SES apply to a broad range of jurisdictional REDD+ activities, including "government-led programs implemented at national or state/ provincial/regional level and for all forms of fund-based or market-based financing." 415 The REDD+ SES provide a voluntary set of social and environmental standards as well as a methodology for developing country governments looking to interpret and apply international guidance on REDD+ safeguards and to build capacity in this aspect of jurisdictional REDD+ readiness. ${ }^{416}$ Several jurisdictions have thus far voluntarily decided to participate in the development or implementation of the REDD+ SES, most notably the State of Acre in Brazil, the Province of Central Kalimantan in Indonesia, Ecuador, Nepal, and Tanzania. ${ }^{417}$ In November 2015, the State of Acre became the first jurisdiction to have completed all ten steps of the REDD+ SES and have received a certificate of approval from the REDD+ SES Initiative Secretariat. $^{418}$

${ }^{12}$ REDD+ SES, “REDD+ Social and Environmental Safeguards. Version 2," available at: $w$ ww.redd-standards.org/standards/redd-social-and-environmental-standards-version-2/5-redd-s es-version-2-english/file (accessed 4 April 2016) at 2.

413 Proforest, REDD+ SES Standards: Briefing on complementarities with other REDD+ social and environmental safeguards mechanisms (Oxford, UK: Proforest, 2010) at 5-6.

414 Interview 77 at 11. See also REDD+ SES, "Exchange \& Learning," available at: www.reddstandards.org/exchange-learning (accessed 4 April 2016).

415 Ibid at 3 .

${ }^{16}$ REDD+ SES, “REDD+ Social and Environmental Safeguards," available at: www.redd-sta ndards.org/process-for-using-redd-ses (accessed 4 April 2016).

417 REDD+ SES, “Country Overview," available at: www.redd-standards.org/index.php?optio n=com_content\&view=article\&id=16\&Itemid=19 (accessed 24 September 2014).

418 REDD+ SES, "State of Acre, Brazil: First country to have completed the full ten-step process," available at: www.redd-standards.org/what-is-new/150-state-of-acre-brazil-first-coun try-to-have-completed-the-full-ten-step-process (accessed 4 April 2016). 


\subsubsection{The Rights of Indigenous Peoples and Local Communities in the REDD+SES}

The REDD+ SES are comprised of eight principles and thirty-four criteria and related indicators that set expectations for the achievement of high social and environmental performance in the context of jurisdictional REDD+ activities. Most of the REDD+ SES can be seen as broadly supportive of the rights of Indigenous Peoples and local communities. On the whole, the REDD+ SES apply to "rights holders," defined as "those whose rights are potentially affected by the REDD+ program, including holders of individual rights and Indigenous Peoples and others who hold collective rights." ${ }^{19}$ Five of the eight principles in the REDD+ SES are specifically designed to ensure the recognition and protection of a range of participatory and substantive rights:

- "The right to lands, territories and resources are recognized and respected" (principle 1);

- "The benefits of the REDD+ program are shared equitably among all relevant rights holders and stakeholders" (principle 2)

- "The REDD+ program improves long-term livelihood security and well-being of Indigenous Peoples and local communities with special attention to the most vulnerable people" (principle 3);

- "All relevant rights holders and stakeholders participate fully and effectively in the REDD+ program" (principle 6); and

- "All rights holders and stakeholders have timely access to appropriate and accurate information to enable informed decision-making and good governance of the REDD+ program" (principle 7).

Furthermore, the criteria and indicators in REDD+ SES most notably mandate the following requirements for jurisdictional REDD+ programs:

- identification of different rights and rights-holders, including through an inventory and mapping exercise (criteria 1.1);

- recognition of, and respect for, the "statutory and customary rights to lands, territories and resources which Indigenous Peoples or local communities have traditionally owned, occupied or otherwise used or acquired" (criteria 1.2); fn. 10. 
- application of "free, prior and informed consent of Indigenous Peoples and local communities for any activities affecting their rights to lands, territories and resources" (criteria 1.3);

- allocation of private carbon rights (where applicable) on the basis of the "statutory and customary rights to the lands, territories and resources" that generated the emissions reductions (criteria 1.4);

- establishment of "[t]ransparent, participatory, effective and efficient mechanisms" for "equitable sharing of benefits of the REDD+ program among and within relevant rights holder and stakeholder groups" (criteria 2.2);

- generation of "additional, positive impacts the long-term livelihood security and well-being of Indigenous Peoples and local communities, with special attention to women and the most marginalized and/or vulnerable people" (criteria 3.1);

- ensuring that all "relevant rights holder and stakeholder groups that want to be involved in REDD+ program design, implementation, monitoring and evaluation are fully involved through culturally appropriate, gender sensitive and effective participation" (criteria 6.2);

- respect and support for and protection of "rights holders' and stakeholders' traditional and other knowledge, skills, institutions and management systems including those of Indigenous Peoples and local communities" (criteria 6.3);

- identification and use of "processes for effective resolution of grievances and disputes relating to the design, implementation and evaluation of the REDD+ program, including disputes over rights to lands, territories and resources relating to the program" (criteria 6.4); and

- compliance with applicable international conventions (criteria 7.1), including those relating to the "human rights of Indigenous Peoples and local communities" (indicator 7.1.2).

In addition to this set of social and environmental safeguards, the REDD+ SES provides guidelines that establish the steps that must be followed by developing countries that want to use and apply the REDD+ SES as part of their jurisdictional REDD+ readiness efforts. Under the guidance of a Standards Committee formed in each jurisdiction, governmental and nongovernmental technical experts facilitate a multi-stakeholder process for the country-specific interpretation and assessment of the REDD+ SES. This process is meant to result in the creation of indicators tailored to local laws, realities, and institutions, and the establishment of a locally relevant, 
accountable, and transparent assessment mechanism. ${ }^{20}$ Because the REDD+ SES is consistent with the UNFCCC guidance on safeguards and the safeguards applied by the World Bank and the UN-REDD Programme, the information gathered through a REDD+ SES assessment may be integrated into reports and communications submitted to a variety of multilateral, bilateral, and private donors. In addition, the REDD + SES has developed an international review mechanism whereby independent experts assess the extent to which a country has followed REDD+ SES guidance, evaluate and offer feedback on the process followed to use REDD+ SES at the country level, and identify lessons and good practices that may be useful to other jurisdictions. ${ }^{421}$

\subsection{HETEROGENEITY IN THE RECOGNITION OF INDIGENOUS AND COMMUNITY RIGHTS IN INTERNATIONAL AND TRANSNATIONAL SITES OF LAW FOR REDD+}

Opinions on how these different sites of law have performed in respecting and ensuring respect for the rights of Indigenous Peoples and local communities continue to be divided among scholars and activists. To be sure, the legal norms developed in many sites of law, especially the UNFCCC and the World Bank FCPF, fall short of fully incorporating the rights enshrined in the UNDRIP or recognized by international and regional human rights bodies. Yet, compared with the reluctance of many actors to accord any importance to human rights issues in the initial stages of the development of REDD+, the final set of Indigenous and community rights recognized across these sites of law reflects a clear evolution in the legal norms constructed for REDD+ as well as an important development more broadly, given the traditional reluctance of multilateral institutions and conservation NGOs to apply human rights norms to their activities.

Yet the processes by which legal norms relating to the rights of Indigenous Peoples and local communities surfaced within international and transnational sites of law for REDD+ have not been free from controversy, however, nor have they yielded a homogenous set of outcomes. As can be seen from Tables 2.1 and 2.2, important divergences have most notably emerged in the

420 REDD+ SES, "Guidelines for the Use of REDD+ Social \& Environmental Standards at Country Level, Version 2," available at: www.redd-standards.org/files/pdf/redd-docs/Standar ds/REDD_SES_Guidelines_Version_2_-_16_November_2012.pdf (accessed 30 December 2013) at $4-5$.

${ }^{421}$ REDD+ SES, “REDD+ International Review. State of Acre, Brazil," available at: www.reddstandards.org/images/REDD_SES_International_Review_for_Acre_ENG.pdf (accessed 4 April 2016) at 1-2. 
TABLE 2.1. Variations in the recognition of the right to free, prior, and informed consent in international and transnational sites of law for REDD+

\begin{tabular}{|c|c|}
\hline $\begin{array}{l}\text { Strong recognition of the } \\
\text { right to free, prior, and informed } \\
\text { consent }\end{array}$ & $\begin{array}{l}\text { Weak recognition of the } \\
\text { right to free, prior, and informed } \\
\text { consent }\end{array}$ \\
\hline $\begin{array}{l}\text { The UN-REDD Social and } \\
\text { Environmental Principles and Criteria } \\
\text { and guidelines on Free, Prior, and } \\
\text { Informed Consent clearly recognize } \\
\text { the right of Indigenous Peoples to free, } \\
\text { prior, and informed consent. } \\
\text { REDD+ SES recognizes the right of } \\
\text { Indigenous Peoples and local } \\
\text { communities to free, prior, and } \\
\text { informed consent. } \\
\text { The third edition of the CCB Standards } \\
\text { recognizes the right of property right } \\
\text { holders, including Indigenous Peoples, } \\
\text { to free, prior, and informed consent. }\end{array}$ & $\begin{array}{l}\text { The UNFCCC Cancun Agreements do } \\
\text { not specifically refer to the right of } \\
\text { Indigenous Peoples to free, prior, and } \\
\text { informed consent and provide instead } \\
\text { that countries should ensure "the full } \\
\text { and effective participation of relevant } \\
\text { stakeholders, in particular, indigenous } \\
\text { peoples and local communities." } \\
\text { Through the application of the World } \\
\text { Bank's Operational Policy on } \\
\text { Indigenous Peoples, the FCPF requires } \\
\text { a "process of free, prior, and informed } \\
\text { consultation with the affected } \\
\text { Indigenous Peoples' communities." }\end{array}$ \\
\hline
\end{tabular}

treatment of the right to FPIC as well as the distinctive status held by Indigenous Peoples across international and transnational sites of law. While the UN-REDD Programme Social and Environmental Principles and Criteria, the REDD+ SES, and the third edition of the CCB Standards offer strong support for the right to FPIC, the UNFCCC Cancun Agreements and the World Bank's Operational Policy on Indigenous Peoples do not. At the same time, the UNFCCC Cancun Agreements, the World Bank's Operational Policies, and the UN-REDD Programme Social and Environmental Principles and Criteria maintain a clear distinction between the obligations owed to Indigenous Peoples and non-indigenous local communities, whereas the REDD+ SES and the third edition of the CCB Standards appear to do away with this distinction altogether.

The recognition and operationalization of human rights norms across sites of law reflects different balances that have been struck between the effectiveness of REDD+ and its implications for justice and equity. ${ }^{422}$ On the whole, the social safeguards for REDD+ adopted within the UNFCCC, the World Bank FCPF, and the UN-REDD Programme represent a series of compromises between actors pressing for the protection of human rights and those concerned with preserving the sovereignty of developing countries and not "over-burdening"

422 See generally McDermott et al., "Operationalizing social safeguards" supra note 54 . 
TABLE 2.2. Variations in the recognition of the distinctive status of Indigenous Peoples in international and transnational sites of law for REDD+

Strong recognition of the distinctive status Weak recognition of the distinctive status and rights of Indigenous Peoples and rights of Indigenous Peoples

The UNFCCC Cancun Agreements maintain a clear distinction between the obligations owed to "Indigenous Peoples" those owed to "members of local communities" and notes the adoption of the "United Nations Declaration on the Rights of Indigenous Peoples" as one of the sources for defining the obligations owed to the former.

The World Bank FCPF Charter distinguishes between "ForestDependent Indigenous Peoples" and "Forest Dwellers." It applies the World Bank Operational Policy on Indigenous Peoples to the former, and expresses principles by which it will engage with "local communities" in the context of forestry that are applicable to the latter.

Although the UN-REDD Social and Environmental Principles and Criteria refer to the "rights of indigenous peoples, local communities and other vulnerable and marginalized groups," the UNREDD Programme guidelines on Free, Prior, and Informed Consent clearly differentiate between the obligations owed to "Indigenous Peoples" and those owed to "forest-dependent communities."
REDD+ SES applies to all relevant "rights-holders" and extends rights generally defined as applying to Indigenous Peoples under international law, such as rights to lands, territories, resources, and free, prior, and informed consent, to both "Indigenous Peoples" and "local communities."

The third edition of the CCB Standards applies a broad definition of "communities" which encompasses "Indigenous Peoples, mobile peoples and local communities," and extends rights generally defined as applying to Indigenous Peoples under international law, such as rights to lands, territories, resources, and free, prior, and informed consent, to all "Property Rights Holders."

their efforts to operationalize jurisdictional REDD+ initiatives at the domestic level. ${ }^{423}$ The recognition of Indigenous and community rights even proved controversial in the context of a voluntary certification scheme like the CCBA,

423 In relation to the UNFCCC, see Interview 33 at 6-7 and Interview 41 at 4 and 7 . In relation to the FCPF, see Interview 79 at $1-2$ and Interview 94 at 1 . In relation to the UN-REDD Programme, see Interview 66 at 6-7 and 16-18 and Observations gathered during participation in GIZ/UN-REDD/FCPF workshop on the full and effective participation of Indigenous Peoples in REDD+ (Weilburg, Germany, September 2013). In relation to all three sites, see 
which was specifically developed to ensure that carbon sequestration projects would deliver multiple and significant social benefits beyond compliance with international law. ${ }^{424}$ In this regard, there is little doubt that the participatory, multi-stakeholder approach underlying the development of the CCB Standards (as well as the REDD+ SES) has provided unique opportunities for adopting stronger rights and protections for Indigenous Peoples and local communities than the consensus-based, state-centered multilateral processes and all of the political compromises that they required on such a sensitive issue. ${ }^{425}$

Finally, the recognition of human rights in the field of REDD+ has also been affected by the mediating influence of existing legal norms present in different sites of law. A comparison of the differing approaches of the World Bank FCPF and the UN-REDD Programme to the recognition of rights is illustrative of the influence of existing legal norms. Specifically, the UN-REDD has adopted a rights-based approach that is consistent with the United Nation's approach to human rights issues. It accordingly refers to the more recent definition of FPIC included in the UNDRIP. By contrast, the World Bank FCPF has stuck with the Bank's risk-based perspective and maintains its Operational Policy on Indigenous Peoples. ${ }^{426}$

As I will demonstrate in subsequent chapters, these variations in the recognition of Indigenous and community rights have created significant opportunities for the translation of rights in national and local sites of law for REDD+. Indeed, the heterogeneous manner in which these rights have been recognized have enabled government officials, activists, lawyers, project developers, and communities to develop innovative interpretations and applications of these rights across different contexts.

also NORAD, "Real-Time Evaluation of Norway's International Climate and Forest Initiative. Synthesising Report 2007-2013. Annexes 3-19. Report 3/2014" (August 2014), available at: www.norad.no/no/evaluering/publikasjoner/publikasjon/_attachment/415168?_down load $=$ true \&_ts $=147$ e976c97e (accessed 6 October 2014) at 368-369 and at 476-477.

424 Interview 77 at $4-5$ and 7 . For instance, the enhanced integration of rights in the third edition of the CCB standards generated some opposition from conservation NGOs concerned with the challenges that this would create for the implementation of REDD+ projects on the ground. See, in particular, the exchange between the Conservation Fund and the CCB Standards Steering Committee in relation to the stringency of community-related requirements in the initial draft of the third edition of the CCB Standards: CCBA, "Compilation by principle of all comments on the Draft Third Edition of the CCB Standards of 31st July 2013 received during the second 6o-day public comment period 1st August to 29th September 2013" (26 October 2013), available at: https://s3.amazonaws.com/CCBA/History_of_the_Sta ndards/CCB+Standards_Second+Public+Comment+Period_Response+to+Comments.pdf (accessed 1 October 2014) at 1-2.

425 Interview 77 at 7 .

426 See Analisa Savaresi, "The Legal Status and Role of Safeguards" in Voigt, supra note 17, 126. 


\section{Rights and Jurisdictional REDD+ in Indonesia}

\subsection{FORESTS, GOVERNANCE, AND RIGHTS IN INDONESIA}

Indonesia's extensive forests constitute the third largest tropical rainforest in the world and have continued to disappear at a rate of .05 percent per year until recently. ${ }^{427}$ The primary drivers of deforestation and forest degradation in Indonesia include legal and illegal logging, agricultural expansion (through the large-scale conversion of forests and peat lands for commercial oil palm plantations as well as small-holder cash-crop subsistence agriculture), mining (especially coal), and forest fires (both natural as well as human-induced in origin). ${ }^{428}$ At the local level, deforestation has also been linked to lack of clarity regarding land and tenure rights; population growth; and the poverty and resource-dependence of rural communities. ${ }^{429}$ Improvements in the governance of forests and land have accordingly been identified as having significant potential for reducing carbon emissions from forest-based sources in Indonesia and contributing to the world's global climate mitigation efforts. ${ }^{430}$

After achieving independence in 1949, Indonesia aggressively pursued the commercial exploitation of its forests and other natural resources on a large scale. In its Basic Agrarian Law, the post-independence presidency of Sukarno recognized three categories of land - state land (tanah negara), privately owned land (tanah hak), and customary lands (hak ulayat) - and limited the latter's recognition to the extent that it was consistent with the national

427 FAO, State of the World's Forests (Rome, Italy: FAO, 2011) at 113.

${ }_{428}$ Giorgio Budi Indrarto et al., The Context of REDD+ in Indonesia: Drivers, agents and institutions (Bogor, Indonesia: CIFOR Working Paper 92, 2012) at 3-9; Mairon Bastos Lima, Joyeeta Gupta, Nicolien van der Grijp \& Fahmuddin Agus, "Case Study: Indonesia” in Joyeeta Gupta, Nicolien van der Grijp \& Onno Kuik, eds., Climate Change, Forests and REDD: Lessons for Institutional Design (Abingdon, UK: Routledge, 2013) 121 at 122-123. Ibid at 124; Indrarto et al., supra note 428 at 9-13. $\quad 43^{\circ}$ Ibid at 13-15. 
interest. ${ }^{431}$ During the New Order, a period of authoritarian developmentalism that ran from the mid-196os to the late 1990s, the Suharto regime consolidated the state's authority over forests and related industries as part of a national drive for economic growth and development. ${ }^{432}$ In the Basic Forestry Law adopted in 1967 , the central government asserted control over all forest areas by removing forests from the scope of application of the Basic Agrarian Law and by not recognizing the existence of adat rights and lands in forests. ${ }^{433}$ For the next several decades, Indigenous Peoples and local communities were systematically excluded from the management of their traditional lands and forests and were prevented from accessing and benefiting from forest resources. ${ }^{434}$

During the reformasi era that followed the fall of Suharto in 1998, Indonesia rapidly transitioned from authoritarian rule to a decentralized system in which many political and administrative responsibilities, including those relating to forests and natural resources, were devolved to provincial, district, and municipal governments. ${ }^{435}$ This process of liberalization and decentralization prompted rural communities across Indonesia to advocate for the recognition of their traditional rights to land and forests as part of a movement known as "adat revivalism." ${ }^{36}$ This period was also characterized by the emergence of an environmental movement in Indonesia and the adoption of a new set of laws and policies aimed at fostering the sustainable management of forests, including through new community-based forms of forest governance. ${ }^{437}$

Basic Agrarian Law (Law 5/1960), art. 3.

Luke Lazarus Arnold, "Deforestation in Decentralised Indonesia: What's Law Got to Do with It?” (2008) 4(2) Law, Environment and Development Journal 75 at $79-81$. On the continuity between colonial and post-colonial governance of forests in Indonesia, see Nancy L. Peluso, Rich Forests, Poor People: Resource Control and Resistance in Java (Berkeley, CA: Berkeley University Press, 1992).

33 Basic Forestry Law (Law 5/1967), art. 5. See Sandra Moniaga, "From bumiputera to masyarakat adat: A long and confusing journey” in Jamie S. Davidson \& David Henley, The Revival of Tradition in Indonesian Politics: The Deployment of Adat from Colonialism to Indigenism (Abingdon, UK: Routledge, 2007) 275 at 279.

Arnold, supra note 432 at $79-81$.

Ibid at $81-82$. This is not to say that the process of decentralization was entirely democratic or that Indonesia has completed its transition to democracy from authoritarianism. See Adam D. Tyson, Decentralization and Adat Revivalism in Indonesia: The Politics of Becoming Indigenous (Abingdon, UK: Routledge, 2010) at 8-10.

$3^{6}$ Ibid at 41-59. See also Moira Moeliono \& Ahmad Dermawan, "The Impact of Decentralization on Tenure and Livelihoods" in Christopher Barr et al., eds., Decentralization of Forest Administration in Indonesia: Implications for Forest Sustainability, Economic Development and Community Livelihoods (Bogor, Indonesia: CIFOR, 2006) 108 at 111-113.

Indrarto et al., supra note 428 at $42-43$. 
In practice, the recognition of adat community forests as well as the establishment of various forms of community forestry has remained riddled with obstacles, such that only 1 percent of Indonesia's forests are legally managed by local communities. ${ }^{43^{8}}$ Although very few of Indonesia's forests have been formally devolved to local communities, numerous communities continue to assert informal claims to own, manage, and benefit from their customary forests. ${ }^{439}$ As a result, forest governance in Indonesia is characterized by a series of ongoing conflicts between local communities seeking recognition of their forest and tenure rights and other actors in the forestry sector, including central, provincial, and district governments and corporations, who are reluctant to accede to requests for greater local authority over, and access to, forests. ${ }^{4{ }^{\circ}}$ Many of the barriers to the full implementation of the rights of local communities to manage their forests are thus similar to those barriers that drive deforestation and forest degradation in Indonesia, such as the competing economic interests of companies engaging in the exploitation of forests and other commodities; the collusion that exists between governments and the natural resource sector; and the broader inefficiencies, resource constraints, tensions, and ambiguities that undermine the effective development and enforcement of forestry laws and regulations across multiple orders of government. ${ }^{441}$

The status and rights of Indigenous Peoples have an equally long and complicated history in Indonesia. ${ }^{4{ }^{2}}$ During the New Order, the Suharto regime denied the very existence of Indigenous Peoples on Indonesian territory and conceived of adat communities in negative terms, as "estranged and isolated communities" (masyarakat terasing) or as "village folk" (orang kampong) disconnected from the national process of development and requiring government assistance and resettlement. ${ }^{443}$ The Suharto regime also adopted

Caleb Stevens et al., Securing Rights, Combating Climate Change: How Strengthening Community Forest Rights Mitigates Climate Change (Washington, DC: Rights \& Resources Institute, 2012) at 19 .

439 Constance L. McDermott, Benjamin Cashore \& Peter Kanowski, Global Environmental Forest Policies: An International Comparison (London, England Earthscan, 2010) at 217-218.

$44^{\circ}$ Indrarto et al., supra note 428 at 38-39; Laurens Bakker \& Sandra Moniaga, "The Space Between: Land Claims and the Law in Indonesia" (2010) 38:2 Asian Journal of Social Science 187 .

$44^{1}$ Myrna Asnawat Safitri, Forest tenure in Indonesia: The socio-legal challenges of securing communities' rights (doctoral dissertation defended at the Faculty of Law of the University of Leiden, December 2010), available at: https://openaccess.leidenuniv.nl/handle/1887/16242 (accessed 27 October 2014) at 239-286.

$44^{2}$ Tyson, supra note 435 at $1-16$.

443 Tania Murray Li, "Articulating Indigenous Identity in Indonesia: Resource Politics and the Tribal Slot" (2000) 42(1) Comparative Studies in Society and History 149 at 154-155. 
a number of policies that would have lasting and adverse consequences for the rights and well-being of adat communities. To begin with, the central government aggressively supported the development of the forestry, mining, agricultural, and tourism sectors and thereby facilitated, through the issuance of licenses as well as intimation and violence, the appropriation of the traditional lands of adat communities by commercial interests. ${ }^{444}$ Moreover, the New Order government created new uniform village administration structures that displaced the local institutions of adat communities and disrupted customary systems of land management. ${ }^{445}$ Finally, the Suharto regime facilitated the relocation of more than five million Indonesians from Java, Madura, and Bali to less populated lands in the outer islands inhabited by adat communities. This process of migration has led to protracted disputes and violent conflicts between migrant and adat populations that continue to this day. ${ }^{446}$

During the 1980s and 1990s, adat communities began to establish organizations and networks to advocate for their rights and to develop relationships with external allies and supporters in the global Indigenous movement (such as the Ford Foundation, the Asia Indigenous Peoples Pact, the International Working Group on Indigenous Affairs, and the Forest Peoples Programme). ${ }^{447}$ Taking advantage of the new opportunities for mobilization presented by the demise of the Suharto regime, more than 200 representatives of Indigenous Peoples organized the First Congress of Indigenous Peoples of the Archipelago in March 1999. ${ }^{44^{8}}$ This congress marked the emergence of a new term that adat communities would use to describe their status as Indigenous Peoples, masyarakat adat, and led to the articulation of a slew of related demands and claims, most notably including recognition of their sovereignty and their rights to manage their traditional lands, forests, and resources. 449 This congress also resulted in the establishment of a new federation of Indigenous Peoples known as AMAN (Aliansi Masyarakat Adat Nusantra Alliance) that now includes 1,992 Indigenous communities throughout Indonesia. ${ }^{40}$ Indonesia’s Forest Zone” (2001) 35(3) Modern Asian Studies 645; Suraya Afiff \& Celia Lowe, "Claiming Indigenous Community: Political Discourse and Natural Resource Rights in Indonesia" (2007) 32 Alternatives: Global, Local, Political 73.

45० AMAN, "Profil Organisasi," available at: www.aman.or.id/wp-content/plugins/downloadsmanager/upload/Profil_AMAN.pdf (accessed 28 October 2014) at 10. 
Over the last fifteen years, with the support and collaboration of international and domestic allies, AMAN has served as an important platform and network for representing the Indigenous Peoples of Indonesia, advocating for their rights vis-à-vis central and regional governments, strengthening their local capacities, institutions, and systems, and promoting the rights of Indigenous women and the education of Indigenous youth. ${ }^{451}$

In addition to the flourishing of the Indigenous movement in Indonesia, the reformasi era was also characterized by a number of legal and policy developments that accorded new, though limited and often ambiguous, recognition to the existence and rights of masyarakat adat communities. $45^{2}$ Notwithstanding some of these important gains, Indigenous Peoples have continued to struggle for the recognition of their distinctive status and the protection of their land and forest rights in Indonesia throughout the zooos. When Indonesia signed the UN Declaration on the Rights of Indigenous Peoples in 2007, the Indonesian government maintained that the concept of Indigenous Peoples was not applicable to Indonesia. It has also rejected domestic and international calls to acknowledge and protect the Indigenous rights of adat communities as defined under international law, ${ }^{453}$ including by ensuring greater recognition of the land and forests rights and tenure systems of adat communities. ${ }^{454}$ As a result of government inaction, Indigenous Peoples living in or near forests have suffered from a lack of tenure security ${ }^{455}$ and the large-scale deprivation of their lands for commercial exploitation or natural resource conservation. ${ }^{456}$ They have also routinely experienced violent clashes with police, security forces, and other rural communities due to land conflicts with other actors in Indonesia. ${ }^{457}$

Ibid.

John Bamba, "Recognition 'In Kind': Indonesian Indigenous Peoples and State Legislation" in Christian Erni, ed, The Concept of Indigenous Peoples in Asia: A Resource Book (Copenhagen, Denmark: IWGIA, 2008) 257 at 264-267. In 1999, the Constitution was most notably amended to incorporate references to the traditional cultural and land rights of adat communities, albeit with the caveat that these remained subordinate to the objective of social development and the unitary nature of the Indonesian Republic (Constitution of the Republic of Indonesia, art. 18(B)(2) and 28(I)(3)).

Rukka Sombolinggi, "Country Profile: Indonesia" in Erni, supra note 452, 377 at 379.

Moniaga, supra note 433 at 285-289. 455 Arnold, supra note 432 at 97.

Davidson \& Henley, supra note 444 at $34-35$.

IFAD, "Update 2011 - Indonesia," available at: www.iwgia.org/regions/asia/indonesia/871-u pdate-2011-indonesia (accessed 28 October 2014). 


\subsection{THE PURSUIT AND GOVERNANCE OF JURISDICTIONAL REDD+ IN INDONESIA}

The origins of jurisdictional REDD+ activities in Indonesia lay in the domestic and international commitments made by the government of President Yudhoyono throughout the second half of the $2000 \mathrm{~s} .{ }^{45^{8}}$ At the domestic level, the Ministry of Forestry established the Indonesian Forest and Climate Alliance (IFCA) to hold an initial set of public consultations on REDD+ and develop eight studies on different aspects of the operationalization of REDD+ in Indonesia. ${ }^{459}$ In addition, it also adopted regulations for the development and implementation of project-based REDD+ activities in 2008 and 2009. ${ }^{460}$ Internationally, President Yudhoyono expressed his strong support for the establishment of a REDD+ mechanism within the UNFCCC, calling on developing countries to reduce their carbon emissions with the funding and support of developed countries. ${ }^{461}$ In September 2009, Yudhoyono most notably committed Indonesia to reducing its emissions by 26 percent through unilateral action or by as much as 41 percent with appropriate levels of international support by $2020.4^{462}$

This commitment created favorable conditions for the pursuit of jurisdictional REDD+ activities in Indonesia, and opened the door for the delivery of aid and technical assistance by multilateral and bilateral actors. ${ }^{4{ }^{6} 3}$ As can be seen from Table 3.1, Indonesia's jurisdictional REDD+ readiness efforts have benefited from the funding and assistance provided by a wide array of multilateral organizations, bilateral aid agencies, foreign corporations, and international NGOs. ${ }^{464}$ The most significant form of support has

${ }_{45}^{8}$ Interview 85 at 1; Interview 89 at 2; Indrarto et al., supra note 428 at 63 .

459 IFCA, "Reducing Emissions from Deforestation and Forest Degradation in Indonesia: REDD

Methodology and Strategies. Summary for Policy Makers" (on file with the author) at 5.

$46 \circ$ Indrarto et al., supra note 428 at 63 .

${ }^{41}$ See, e.g., Peter Gelling, "Indonesia Seeks Allies for Pay-for-Forests Plan" New York Times, 28 October 2007, at 14 .

${ }^{62}$ Intervention by H.E. Dr. Susilo Bambang Yudhoyono, President of the Republic of Indonesia on Climate Change at the G-20 Leaders Summit, 25 September 2009, Pittsburgh, PA, available at: http://forestclimatecenter.org/files/2009-09-25\%2oIntervention \%zoby\%zoPresident\%zoSBY\%zoon\%zoClimate\%zoChange\%zoat\%zothe\%zoG-zo\%zoLead ers\% 20Summit.pdf (accessed 9 September 2014) at 2.

463 Interview 44 at 6; Interview 85 at 1 . See also Kristine Veierland, Inclusive REDD+ in Indonesia. A Study of the Participation of Indigenous People and Local Communities in the Making of the National REDD+ Strategy in Indonesia (Master's Thesis, Department of Political Science, University of Oslo, October 2011) at 43.

464 Indonesia is the largest recipient of funding for REDD+ in the world, with 2.4 billion US dollars having been pledged by donors, of which around 102 million US dollars have been disbursed since 2009. Forest Trends, "REDDx - Indonesia," available at: http://reddx.foresttrends.org/country/indonesia/ (accessed 10 November 2014). 
TABLE 3.1. Overview of transnational support for jurisdictional REDD+ readiness activities in Indonesia

\begin{tabular}{|c|c|}
\hline $\begin{array}{l}\text { Multilateral } \\
\text { programmes }\end{array}$ & $\begin{array}{l}\text { From } 2010 \text { to } 2012 \text {, a dedicated UN-REDD National } \\
\text { Programme provided Indonesia with funding, capacity- } \\
\text { building, and technical assistance to support stakeholder } \\
\text { participation, the development of a reference emissions level } \\
\text { and an MRV system, the creation of a finance mechanism, } \\
\text { and the pursuit of pilot activities at the provincial and district } \\
\text { levels. }{ }^{465} \text { In addition, since } 2009 \text {, the World Bank FCPF } \\
\text { has provided funding and technical assistance for the } \\
\text { development of reference emission levels and an MRV } \\
\text { system. }{ }^{66}\end{array}$ \\
\hline Bilateral aid agencies & $\begin{array}{l}\text { The Norwegian government has committed to providing up to } \\
1 \text { billion US dollars in performance-based payments for } \\
\text { REDD+ and } 30 \text { million US dollars in start-up funds for } \\
\text { national REDD+ readiness activities. }{ }^{467} \text { Indonesia has also } \\
\text { received funding and technical assistance from the bilateral } \\
\text { aid agencies of Japan, France, Australia, Germany, and } \\
\text { the UK. }{ }^{468}\end{array}$ \\
\hline $\begin{array}{l}\text { Nongovernmental } \\
\text { actors }\end{array}$ & $\begin{array}{l}\text { A number of American charitable foundations, such as the Ford } \\
\text { Foundation, Packard, and the Climate and Land Use } \\
\text { Alliance, multinational corporations, such as Macquarie, } \\
\text { and international NGOs, such as Conservation } \\
\text { International, the World Wildlife Fund, and the Nature } \\
\text { Conservancy have contributed funding for the pursuit of } \\
\text { REDD+ projects in Indonesia. }{ }^{469}\end{array}$ \\
\hline
\end{tabular}

come from the Norwegian International Climate and Forests Initiative (NICFI). ${ }^{40}$ From May 2010 to March 2014, 58 percent of an initial US \$30 million was disbursed to support the development of plans, systems, and capabilities for the pursuit of jurisdictional REDD+ across Indonesia as well as in the pilot province of Central Kalimantan. ${ }^{471}$ In addition, Norway has funded the programs of numerous multilateral institutions as well as the

Letter of Intent between the Government of the Kingdom of Norway and the Government of the Republic of Indonesia on Cooperation on reducing greenhouse gas emissions from deforestation and forest degradation (26 May 2010) (on file with the author); Indonesia-Norway Partnership Joint Concept Note (3 December 2010) (on file with the author).

466 NORAD, supra note 423 at 260. $\quad 4^{67}$ Ibid at 265-266. $\quad 468$ Ibid at 57-58.

469 NORAD, supra note 423 at $264 . \quad 470 \quad$ Ibid at $264-265$.

${ }^{471}$ UN-REDD Programme, "National Programme Final Report - Indonesia” (18 January 2013) (on file with the author) at 4 . 
activities of a large number of development and human rights NGOs in Indonesia. ${ }^{42}$

Pursuant to its bilateral agreement with Norway, the government of President Yudhoyono established a REDD+ Taskforce in the Summer of 2010 that brought together representatives of the National Development Planning Agency (BAPPENAS), the Ministry of Forestry, the Ministry of Finance, the State Ministry for Environment, the National Land Agency (BPN), the Secretariats of the Cabinet and Presidential Office, and the President's Work Unit for the Supervision and Management of Development (UKP 4$)$. Reporting directly to the President, its main tasks included elaborating a National REDD+ Strategy and undertaking preparations for the establishment of REDD+ institutions, financial mechanisms, and measurement, reporting, and verification systems. This REDD+ Taskforce was also supported by a number of technical working groups, comprised of experts from government, academia, and civil society, working on key aspects of REDD+ readiness (such as governance, multi-stakeholder processes, safeguards, or finance). ${ }^{473}$ This initial taskforce ended its mandate in June 2011, and was thereafter succeeded by a second and third taskforce and finally by a special team established with the express purpose of preparing for the establishment of a REDD+ Agency. ${ }^{474}$ This REDD+ Agency was created in August 2013 and was tasked with the responsibility of managing and coordinating all jurisdictional REDD+ activities in Indonesia. ${ }^{475}$

\section{$3 \cdot 3$ THE RIGHTS OF INDIGENOUS PEOPLES AND LOCAL COMMUNITIES IN JURISDICTIONAL REDD+ READINESS ACTIVITIES IN INDONESIA}

\subsubsection{Rights in the Development of a National REDD+ Strategy}

In the early stages of Indonesia's jurisdictional REDD+ readiness efforts, various ministries and agencies engaged in policy research and planning that would lay the groundwork for the later development of a national REDD+ strategy. During the fall of 2007, the IFCA organized a series of

472 World Bank - Grant Reporting and Monitoring (GRM) Report, "Indonesia - FCPF Readiness Preparation Grant" available at: http://forestcarbonpartnership.org/sites/fcp/files/ Indonesia\% 20GRM\%20FY2013\%2oRecipient\%zoExecuted.pdf (accessed 6 January 2013).

473 Letter of Intent between the Government of the Kingdom of Norway and the Government of the Republic of Indonesia on Cooperation on reducing greenhouse gas emissions from deforestation and forest degradation (26 May 2010) (on file with the author).

474 Forest Trends, "REDDx - Indonesia" available at: http://reddx.forest-trends.org/country/in donesia/ (accessed 10 November 2014).

475 Ibid. 
national workshops and developed eight studies on different aspects of the operationalization of REDD+ in Indonesia. These studies were eventually brought together into a consolidated report released by the Ministry of Forestry in early 2008 known as REDD-I. This report identified the emerging international consensus around the key elements of REDD+ and set out the next steps for the piloting of REDD+ mechanisms and activities in Indonesia. ${ }^{46}$ Although it acknowledged the role that clarifying land tenure and forest management rights and engaging with local communities could play in the success and effectiveness of REDD+ activities, ${ }^{477}$ it did not address, nor refer to, the participatory or substantive rights of Indigenous Peoples or local communities. ${ }^{47^{8}}$ On the other hand, in July 2008, BAPPENAS issued a national development plan focused on Indonesia's response to climate change, in which forestry was identified as a priority area for domestic climate mitigation efforts. ${ }^{479}$ This report recognized the significance of the rights of Indigenous Peoples and forest-dependent communities and most notably stated that: "Crucial for successful implementation of REDD-I will be the acknowledgement and inclusion of the rights of indigenous people and rural people who depend upon forest resources for their livelihoods, in Indonesia, this number might exceed 60 million people." 480 The contrast between these two reports reflected the traditional reluctance of the Ministry of Forestry to embrace participatory and substantive rights that might threaten its stranglehold on forest governance and associated revenues and the comparatively greater openness of BAPPENAS to the rights and concerns of Indigenous Peoples and rural communities. ${ }^{481}$

Another important process that fed into the development of a national REDD+ strategy was the preparation and submission of an R-PP by the Ministry of Forestry under the FCPF Readiness Mechanism. This R-PP was developed by an ad hoc inter-ministerial working group and drew on the studies prepared by IFCA as well as a set of consultations with national, regional, and local government representatives, NGOs, local communities, international partners, and the private sector carried out in 2008 and $2009.4^{82}$

\footnotetext{
$47^{6} \quad$ IFCA, supra note 459. 477 Ibid at 11, 18, 20, 46, and 66.

$4^{8}$ The report included no references to the terms Indigenous Peoples, customary communities, or traditional communities and did not refer to the potential application of such rights as the right to free, prior, and informed consent.

479 Indrarto et al., supra note 428 at 50.

$4^{8 \circ}$ Cited in Patrick Anderson \& Torry Kuswardono, "Report to the Rainforest Foundation Norway on REDD in Indonesia” (September 2008) (on file with the author) at 8.

$4^{81} \quad$ Ibid. Interview 61 at 2 ; Interview 86 at $2-3$.

$4^{82}$ Republic of Indonesia, "R-PLAN" (May 2009), available at: www.forestcarbonpartnership.o rg/sites/forestcarbonpartnership.org/files/Documents/PDF/Marzo1o/Indonesia_Rplan_Ma y2009_with_disclaimer.pdf (accessed 14 November 2014) at 13-15.
} 
These consultations enabled Indigenous activists to raise concerns with government officials about their approach to Indigenous peoples and local communities in the drafting of the R-PP, specifically the lack of recognition of their Indigenous status and their rights to lands, resources, and to FPIC. ${ }^{48} 3$ The RPP submitted to the FCPF in May 2009 only partially addressed some of these rights-related issues, however. On the one hand, the R-PP acknowledged the importance of ensuring that Indigenous Peoples and forest dwellers could participate in, and benefit from, the implementation of REDD+ activities and committed to consulting them in the development of policies and programs for REDD+ in Indonesia. ${ }^{44}$ On the other hand, the R-PP did not address the potential risks that REDD+ might pose to the rights of Indigenous Peoples and local communities, nor did it recognize the distinctive set of rights held by Indigenous Peoples, claiming instead that "[f]orest dwellers and indigenous people, like other Indonesian citizens, have the same rights and responsibilities as Indonesian citizens according to national regulations." ${ }^{85}$

Unsurprisingly, the R-PP submitted by Indonesia to the FCPF in May 2009 attracted criticisms at home and abroad. In particular, AMAN and Sawit Watch ${ }^{86}$ addressed a letter to the Minister of Forestry (with CCs to key officials in the FCPF and the World Bank), in which it criticized the Indonesian government for failing to fully and adequately consult with Indigenous Peoples and to recognize their participatory and substantive rights (as protected through the FCPF Charter as well as international human rights law more broadly). AMAN and Sawit Watch closed the letter by calling on the Indonesian government to "establish an effective process of consultation and collaboration with Indigenous Peoples' organizations and authorities to enable their participation in the decisions about the development of REDD that will impact on their lives." ${ }^{487}$ In their reviews of Indonesia's R-PP, the third-party experts from the technical advisory panel recommended that Indonesia take additional steps to ensure the involvement of Indigenous Peoples and forest-dependent communities in its REDD+ policy planning

$4^{83}$ Ibid at 18. See also FCPF, "Readiness Preparation Proposal Assessment Note on a Proposed Grant in the Amount of US\$3.6 Million to the Republic of Indonesia for REDD+ Readiness Preparation Support" (3 February 2011) (on file with the author) at 77-78.

$4^{84}$ Republic of Indonesia, "R-PLAN" supra note 482 at $26 . \quad 4^{85} \quad$ Ibid.

486 Established in 1998 , Sawit Watch is an Indonesian public interest law and advocacy NGO that aims to achieve environmental justice for smallholder farmers, laborers, and Indigenous Peoples in seventeen provinces across Indonesia. See FPP, "Sawit Watch," available at: www .forestpeoples.org/partners/sawit-watch (accessed 18 November 2014).

$4^{87}$ AMAN \& Sawit Watch, "Indonesian Draft Readiness Plan, 16 October 2008" (15 May 2009), available at: www.forestcarbonpartnership.org/sites/forestcarbonpartnership.org/files/AMA N_on_Indonesia_R-Plan_o.pdf (accessed 14 November 2014) at 3 . 
process, assess the potential negative impacts of REDD+ on the livelihoods of forest communities and Indigenous Peoples, and address the issue of the distribution of benefits. ${ }^{48}$ At its third meeting in June 2009, the FCPF Participants' Committee arrived at similar conclusions and moreover discussed the application of the World Bank's social and environmental safeguards as well as the consideration of the land and forest tenure and resource rights of Indigenous Peoples and local communities. ${ }^{489}$ Upon approving Indonesia's R-PP in June 2009, the FCPF Participants' Committee thus requested that the World Bank and Indonesia work closely with one another to resolve these issues before the conclusion of a grant agreement. ${ }^{49}$ After two years of additional due diligence to, among other things, clarify the application of the World Bank's Operational Policy on Indigenous Peoples to Indonesia's jurisdictional REDD+ readiness efforts, ${ }^{49^{1}}$ the Indonesian government and the World Bank concluded a readiness grant agreement in June $2011 .^{492}$ 2009), available at: www.forestcarbonpartnership.org/sites/forestcarbonpartnership.org/files/ Indonesia_R-Plan_TAP_synthesis_o6-2-o9.pdf (accessed 14 November 2014) at 2, 4, 6-8, and 10 ;

$4^{89}$ FCPF, "Participants' Committee: Third Meeting (16-18 June, 2009, Montreux). PC Discussions of Indonesia’s Readiness Preparation Proposal. Summary Report,” available at: http://forestcarbonpartnership.org/sites/fcp/files/Summary\%zoReport\%zoR-PP\% zoIndonesi a\% 20FINAL.pdf (accessed 14 November 2014) at 1-2.

$49^{\circ}$ FCPF, “Third Participants' Committee, 16-18 June, 2009, Montreux, Switzerland. Resolution PC/3/2009/5 Indonesia Readiness Preparation Proposal.” available at: http://forest carbonpartnership.org/sites/fcp/files/Resolution\%205-\%20R-PP-Indonesia\%2oFINAL.pdf (accessed 14 November 2014) at $1-2$.

In February 2011, World Bank officials, acknowledging that the Indonesian government was "still reluctant to recognize the term indigenous peoples and any particular rights afforded them," specifically concluded that the Bank's Operational Policy on Indigenous Peoples would apply to communities with the status of "Masyarakat Adat" and "Masyarakat Terasing" under Indonesian law (FCPF, "Readiness Preparation Proposal Assessment: Indonesia” supra note 482 at $\left.3^{8}\right)$.

492 FCPF, "REDD Readiness Progress Sheet. Country: Indonesia” (October 2013), available at: http://forestcarbonpartnership.org/sites/fcp/files/2013/Oct2013/Indonesia\%2oFCPF\%2oRED D\%20Readiness\%20Progress\%20Fact\%20Sheet\%20Oct\%202013.pdf (accessed 18 November 2014) at 1 . In the end, this two-year delay in the conclusion of a readiness grant agreement considerably limited the influence of the FCPF on the development of Indonesia's REDD+ readiness policies. Indeed, by June 2011, Indonesia's jurisdictional REDD+ readiness efforts were well underway as a result of the activities of the UN-REDD Programme and the National REDD+ Taskforce. See NORAD, "Real-Time Evaluation of Norway's International Climate and Forest Initiative Contributions to National REDD+ Processes 2007-2010. Country Report: Indonesia” (March 2011), available at: www.norad.no/en/tools-a nd-publications/publications/publication/_attachment/333468?_download=true\&_ts=12f9 be6fi13 (accessed 6 October 2014) at 55 . 
In any case, the development of a national REDD+ strategy for Indonesia truly began after its inclusion as a key deliverable in the Letter of Intent Indonesia concluded with Norway in May 2010.493 This task was initially entrusted to BAPPENAS, which worked with other ministries to create a process and structure for this purpose. ${ }^{494}$ This led to the establishment, in July 2010, of a Steering Committee bringing together government officials from several ministries ${ }^{495}$ as well as an Implementation Team comprised of representatives from government, international organizations, and civil society. ${ }^{496}$ Given that the Letter of Intent specified that "all relevant stakeholders" (including "Indigenous Peoples, local communities and civil society") should be given the opportunity to fully and effectively participate in the design of REDD+ policies and plans, ${ }^{497}$ BAPPENAS worked closely with the UN-REDD Programme to develop a plan for holding a series of multi-stakeholder consultations at the national and regional levels..$^{49}$

Throughout the summer of 2010 , several drafts of the strategy were produced and discussed by various officials and stakeholders as well as presented for public feedback in August 2010.499 These efforts culminated in a first complete draft released to the public in September 2010. In comparison with the R-PP submitted to the FCPF in May 2009, this draft national strategy was much more attentive to the prevalence of conflicts over land tenure and forest rights ${ }^{500}$ and the lack of recognition of the traditional rights held by

Letter of Intent, supra note 465 at 2. 494 Veierland, supra note 463 at $44-47$.

The ministries represented on the steering committee included: BAPPENAS, the Ministry of Forestry, the Ministry of Agriculture, the Ministry of Mining and Energy and the National Council on Climate Change.

The Implementation Team included representatives from the Ministry of Forestry, the Ministry of Agriculture, and BAPPENAS, UNDP, Bogor Agricultural University, CIFOR, ICRAF, AMAN, the Indonesian Center for Environmental Law, The Partnership for Governance Reform, The Nature Conservancy, the World Wildlife Fund, and Conservation International.

97 Letter of Intent, supra note 465 at 1.

Veierland, supra note 463 at 46-47. See UN-REDD Programme News, "Indonesia's National REDD+ Strategy: UN-REDD Indonesia is collaborating with the National Development Planning Agency (BAPPENAS) to conduct an intensive multi-stakeholder consultation process that will produce the world's first fully participatory National REDD+ Strategy" (12 September 2010), available at: www.un-redd.org/Newsletter12/Indonesia_National_REDD_ Strategy/tabid/5533/Default.aspx (accessed 17 November 2014).

499 Veierland, supra note 463 at $47-48$.

BAPPENAS, Indonesia National REDD+ Strategy (Draft 1 - September 2010) (on file with the author) at 52 ("Forest lands with its diversity of ownership rights, status and faction have become battlefields for stakeholders with various interests which are not yet finished by now. Conflicts and disagreements on who should be controlling and managing forest and State Forest Area are sources of various anxieties, which often result in vandalisms. The sources of these anxieties can be found in the interpretation of definitions and forest locations in 
"Indigenous communities": "Legal dualism on the acknowledgement of traditional rights in forest area and non-forest area becomes one of the tenurial issues. The inexistence of formal rights for traditional societies result in the inability to make a natural resource-based decision in their traditional territory weakens their potential abilities in supervising forest area. At the same time, procedures which enable them to be acknowledged as legal society seem very difficult and long." ${ }^{\circ 1}$ This draft strategy also identified the unjust distribution of economic benefits from forestry between governments and forest-dependent communities as a driver of deforestation and forest degradation ${ }^{502}$ and thus proposed an economic empowerment program to strengthen and diversify their livelihoods and sources of incomes. ${ }^{503}$ Finally, the draft strategy noted that the establishment of a REDD+ mechanism in Indonesia should " $[\mathrm{n}]$ ot only consider the economic aspect but also the environment and social aspects, including the traditional and local community rights as well as the participation role of various parties to ensure that the reduction of deforestation and forest degradation is effective and permanent." ${ }^{\circ} 4$ To these ends, it envisaged various forms of cooperation with local communities ${ }^{505}$ and anticipated the development of a "non-carbon" MRV system that would include social and environmental safeguards. ${ }^{506}$ Despite its greater acknowledgement of the importance of land rights and tenure security and the need to work collaboratively with local communities, this first draft did very little to advance the recognition and protection of the rights of Indigenous Peoples as such.

This first draft was subsequently discussed through public consultations held with multiple stakeholders (including CSOs working with Indigenous Peoples) across six regions in Indonesia in October 2010.507 In response to the release of the first draft strategy, a coalition of Indonesian CSOs working at the intersections of human rights and environmental issues offered a number of recommendations to BAPPENAS. ${ }^{\circ 08}$ First, these organizations called for the

Indonesia and its authority. Different interpretations cause basic differences on the roles of controlling the forest resources by different actors and institutions. Conflicts over the role of controlling area and natural resources caused by unclear tenurial rights must be finalized through a serious attempt in a clear action strategy.”)

501 Ibid at 52. ${ }^{502}$ Ibid at 65. ${ }^{503}$ Ibid at 35. ${ }_{504}$ Ibid at $30 .{ }^{505}$ Ibid at 36.

506 Ibid at 46 .

507 These regional consultations were held in Bali, Java, Kalimantan, Papua, Sulawesi, and Sumatra. Five of the consultations were facilitated and funded by the UN-REDD Programme and the other two were facilitated and funded by Kemitraan. In all, 387 individuals participated and hailed from government, academia, civil society, and the private sector. See Veierland, supra note 463 at 48-50.

508 HuMa et al., Proposal of Civil Society Networking for the First Draft of National REDD+ Strategy Jakarta, 25 October 2010 (on file with the author). 
protection of the forest rights of Indigenous Peoples and local communities to serve as one of the main objectives of Indonesia's national REDD+ strategy. ${ }^{509}$ Second, they requested that the strategy refer to, and incorporate, standards set by international human rights instruments, including the UN Declaration on the Rights of Indigenous Peoples. ${ }^{50}$ Third, they advocated for the recognition of the role and contribution of Indigenous Peoples and local communities in the sustainable management of forests, citing academic research on the effectiveness of community forestry in supporting carbon sequestration..$^{11}$ Finally, they noted that the strategy did not actually provide solutions for the lack of forest tenure clarity and thus proposed the adoption of measures that could actually resolve forest tenure conflicts. ${ }^{512}$

After one final expert's meeting, a revised draft of the national REDD+ strategy was prepared in November 2010..$^{53}$ This revised draft responded to many of the demands formulated by the Indonesian CSOs, especially with respect to the participatory rights of Indigenous Peoples and local communities. Indeed, the second draft strategy consistently emphasized the importance of ensuring the participation of Indigenous Peoples and local communities in the development and implementation of REDD+ activities ${ }^{514}$ and, most notably, endorsed the view that their involvement in forest management was an effective way of reducing carbon emissions from forest-based sources. ${ }^{515}$ In particular, the involvement of "indigenous peoples and forest communities" was presented as "essential" due to the potential role that local knowledge can play in the reduction of carbon emissions as well as the need to avoid the adverse consequences that can be caused by how forests are utilized by other parties. ${ }^{516}$ As a result, the strategy committed to a range of activities

509 Ibid at 2. $5^{10}$ Ibid. $5^{11} \quad$ Ibid at 2-3. $5^{12}$ Ibid at 3.

513 Veierland, supra note 463 at 51.

514 BAPPENAS, Indonesia National REDD+ Strategy (Draft 2-18 November 2010) (on file with the author) at 12,15 , and 37 .

515 Ibid at $42-43$.

516 Ibid at 43: "Involving indigenous peoples and forest communities who live in the surrounding forests is essential for socio-cultural conditions in a diverse society such as Indonesia. Different socio- cultural conditions often have local knowledge in utilizing forests in sustainable ways. In the context of the community and modern rules, local knowledge, with all its informal rules, becomes less consistent and less compatible with modern rules which are equipped with indicators and measurement mechanisms which facilitate the transaction mechanism/market place. Accordingly, local knowledge with its customary laws must be recognized and internalized into the modern legal system. It is important to accommodate local knowledge into the system of modern rules without losing the strength and spirit of informal traditions or losing the noble values in it. It is important to maintain the local knowledge, so it will not be eroded, but can be implemented as a unit, so that actors of local knowledge would obtain results/rewards which are proportional to the forest utilization carried out by anyone. Involving these groups in forest management and utilization needs 
that aimed to increase the participation and capacity of Indigenous Peoples (among other stakeholders) in the implementation of REDD+ activities, maintain and build upon their local knowledge in relation to sustainable forest management, establish fair and effective mechanisms to resolve conflicts between the multiple actors that use or depend upon forests, and ensure the application of the principle of free, prior, and informed consent of local communities. ${ }^{517}$ On the other hand, while the second draft strategy reiterated the problems associated with conflicts over forest tenure and use and the lack of recognition of Indigenous rights ${ }^{518}$ and identified the settlement of these issues as integral to the operationalization of REDD,$+{ }^{519}$ it did not provide much clarity on the way in which disputes over forest tenure might be resolved. Although international and domestic NGOs welcomed the formal introduction of rights language and principles in the development of Indonesia's national REDD+ strategy, they also highlighted the challenges associated with the lack of access to land and resources experienced by Indigenous Peoples and local communities and the need to establish "effective and accessible mechanisms of redress that would help resolve the numerous and protracted land feuds across the country." 520

In late 2010, the second draft of the national REDD+ strategy was then handed over by BAPPENAS to the REDD+ Taskforce, which established a working group comprising senior government officials and nongovernmental experts to prepare a final draft. ${ }^{521}$ This working group held an additional series of national and subnational consultations with multiple stakeholders in several provincial capitals in 2011 and $2012 . .^{22}$ It also had to contend with an alternative draft REDD+ strategy that was released by the Ministry of Forestry in April 2012.523

to consider the principle of consent of local communities (free prior informed consent/ FPIC). Furthermore, involvement of forest communities is very important to avoid and prevent them from becoming strangers in their own region, and even become negatively affected by forest utilization activities carried out by parties. Involvement of forest communities is also necessary for emission reduction processes, and moreover, if there is local knowledge which is applied as a normal rule; they then will obtain results/rewards from the use of instruments they have created. Therefore, indigenous peoples and communities in the surrounding of forests will become important actors and responsible users."

517 Ibid at $43-44 \quad 518 \quad$ Ibid at 23. 519 Ibid at 40.

520 FPP, PUASAKA \& HUMA, "National Update on REDD+ in Indonesia" (October 2011) (on file with the author) at 4 .

521 Indrarto et al., supra note 428 at 57.

522 UN-REDD Programme, "The Role of UN-REDD in the Development of REDD+ in Indonesia" (2012) (on file with the author) at 11.

523 Ministry of Forestry, "Draft National Strategy on Enhancing and Maintaining Forest Carbon Stock through Sustainable Forest Management Activities: A Strategic Assessment” (April 2012) (on file with the author). 
In the end, this working group produced a comprehensive draft strategy that sought to integrate the drafts prepared by BAPPENAS and the Ministry of Forestry ${ }^{24}$ as well as the feedback received from various governmental representatives and nongovernmental stakeholders. ${ }^{25}$ The strategy was then finalized by the REDD+ Taskforce and officially released in June $2012 .{ }^{26}$

Indonesia's National REDD+ Strategy is built on five pillars: (1) the creation of an institutional system for REDD+ (including a REDD+ agency and the development of a funding instrument known as FREDD-I as well as an MRV system); (2) the establishment of a sound legal and regulatory framework for forest governance and the implementation of REDD+ activities at the jurisdictional and project levels; (3) the implementation of strategic programs focused on the conservation and rehabilitation of forests and the sustainable management of agriculture, forestry, and mining activities across landscapes; (4) the promotion of a paradigm shift in the way in which land and forests are used and governed by relevant actors; and (5) the inclusion and involvement of multiple stakeholders in the design and operationalization of REDD+ activities. ${ }^{527}$ Each of these pillars addresses in significant and concrete ways the rights and concerns of Indigenous Peoples and local communities. ${ }^{528}$ With respect to land and resource rights, the strategy states that "[ $t$ ]he people have a constitutional right to certainty over boundaries and management rights for natural resources" and that "[l] and tenure reform is an important prerequisite to create the conditions required for successful implementation of REDD+." 529 Accordingly, the strategy provides for the Indonesian government to have the National Land Agency undertake "a survey of land occupied by indigenous peoples and other communities," resolve disputes over land tenure "using existing statutory out-of-court settlement mechanisms," and ensure that "the principle and processes of Free, Prior, and Informed Consent (FPIC) are internalized in the issuance of all permits for the exploitation of natural resources." 530 In addition, the strategy commits to reducing the bottlenecks of "processes to delineate forest areas (...) as a sign of respect towards parties with rights to land," 531 supporting the development of "sustainable local

524 Indrarto et al., supra note 428 at 70; Julian Caldecott et al., "Indonesia-Norway REDD+ Partnership: Second Verification of Deliverables. Final Report" (8 November 2013), available at: www.regjeringen.no/upload/KLD/KL/Klima-og-skogprosjektet/IndonesiaNorwayREDD SecondVerificationFinalReport.pdf (accessed 10 November 2014) at 17.

525 Interview 86 at 13. See also Indrarto et al., supra note 428 at 83 . ${ }_{526}$ Interview 86 at 13.

527 Indonesian REDD+ Task Force, "REDD+ National Strategy" (June 2012) (on file with the author) at 7 .

${ }_{22} 8$ The strategy uses the term masyarakat adat to refer to Indigenous Peoples - the term conceived and preferred by adat activists in Indonesia.

529 Ibid at $18 . \quad 53^{\circ} \quad$ Ibid. 531 Ibid at 21. 
economies based on alternative livelihoods, expanded job opportunities, and the management of forests by local communities," 532 and implementing sustainable forest management, including in "timber areas cultivated by local communities, communal forests, village plantations." 533

As far as participatory rights are concerned, the strategy clearly recognizes the importance of facilitating and supporting public participation in the design and implementation of REDD ${ }^{534}$ and most notably provides that the REDD+ Agency "will implement and apply the principles of FPIC in all REDD+ programs and projects" in order to "ensure fairness and accountability for indigenous and local peoples whose lives and rights will be affected by REDD+ activities." 535 The strategy also sets out a series of detailed principles that should guide the implementation of FPIC in the context of Indonesia's jurisdictional REDD+ activities. ${ }^{536}$ In this regard, it is worth noting that the principle of FPIC is conceived as applying not only to Indigenous Peoples (as would be the case under international law), but also to local communities who are affected by the implementation of REDD+.

With respect to the development of a framework and information system for social and environmental safeguards, the strategy specifies the protection of human rights as a core objective: "it is imperative to specifically design the social safeguards framework for the protection and benefit of vulnerable groups, including indigenous peoples and local communities living in and around forests, whose livelihoods depend on forest resources; women, who face the full brunt of changes in family income; and other societal groups, whose social, economic, and political status put them in a weak position in terms of fulfillment of their human rights." 537 Further, the strategy sets a

532 Ibid at 22. 533 Ibid at 23. 534 Ibid at 25-27. $535 \quad$ Ibid at 27.

536 Ibid at 28. This strategy most notably provides that consultations with Indigenous Peoples and local communities affected by REDD+ programs or activities should: be "carried out without force, intimidation, manipulation, or pressure in any form to seek [their] consent”; involve them "in every step and process that affects them either directly or indirectly (...) through traditional authorities, or through representative organizations selected on the basis of traditional systems adhered to by the given indigenous community"; aim "to achieve broad consensus or the specific agreement of the indigenous and local communities potentially affected (...) through legal mechanisms, indigenous law practices, or local traditions and habits"; be "based on complete, balanced, honest, unbiased, and easily understood information concerning the alternatives and choices existing for the public within the implementation of REDD+ activities, along with the consequences of each alternative choice"; be "within an adequate frame of time before permits are legalized or activities commenced"; serve as "the beginning of ongoing or regular communication between members of the community and the would-be implementers of REDD+ activities"; and be guided by "agreement on the manner of public consultations, its protocols and mechanisms, including those for complaints and conflict resolution relating to each stage of REDD+ activities." Ibid at 29 . 
number of minimal requirements for the preparation of the criteria and indicators in Indonesia's safeguards framework. ${ }^{538}$ The strategy also provides the National REDD+ Agency with the responsibility of further developing and implementing a safeguards information system, which should acknowledge the "the right of the public to land and forests that accommodates not only formal legal recognition, but also indigenous law rights and historical claims." 539

Finally, Indonesia's National REDD+ Strategy discusses the importance of developing fair, transparent, and accountable systems and mechanisms for benefit-sharing. ${ }^{54}$ Here again, the strategy accords significant importance to the land and resource rights of local communities, specifying that parties with "rights over the area off the REDD+ program/project/activity location have the right to payment" and requiring the clarification of the status of land rights in a given area and the distribution of benefits to communities that hold these rights or otherwise contribute to the reduction of carbon emissions. ${ }^{541}$ The eventual development of this system also falls to the National REDD+ Agency, which is tasked with formulating and operationalizing a funding instrument for REDD+. ${ }^{5{ }^{2}}$

The National REDD+ Strategy has been greeted with cautious enthusiasm by Indonesian CSOs advocating for the rights and interests of Indigenous Peoples and local communities. For the most part, the National REDD+ Strategy has been seen as a promising development in the recognition and protection of the participatory and resource rights of Indigenous Peoples and local communities. ${ }^{543}$ Recognizing that the National REDD+ Strategy

$53^{8}$ Ibid at 30: "[a]cknowledgement and protection of the basic rights of indigenous peoples and local communities to: (i) state their opinions about whether they approve REDD+ activities in the areas in which they live; (ii) participate; (iii) get information; (iv) object to or criticize public decisions relating to REDD+ projects; (v) have full rights to natural resources, not only on the basis of documents, but based on historical use; and (vi) an equitable level of benefits." Ibid. $\quad 540$ Ibid at $32 . \quad 541$ Ibid. $\quad 542$ Ibid at 8-9 and 11-12.

543 See, e.g., Anja Lillegraven \& Rukka Sombolinggi, "Neither cheap nor quick, but critical" Development Today (26 March 2014), available at: www.development-today.com/magazine/ 2014/dt_3_2014/opinion (accessed 18 November 2014) ("Indonesia has developed a progressive national REDD+ strategy that targets underlying causes of deforestation previously outside the public discourse, such as corruption, weak governance, lack of law enforcement and unclear tenure. (...) The recognition of indigenous peoples has improved since Norway signed the agreement with Indonesia. Their crucial role in forest management has been officially acknowledged. The national REDD+ strategy recognises that tenure reform is a prerequisite for successful implementation of REDD+."); Leo Wajyudi \& Sopril Amir, "REDD+ National Strategy, Way to Indigenous Peoples' Rights and Existence" (7 August 2012), news item on website of the Indonesian REDD+ Task Force (on file with the author) (quoting the Secretary-General of AMAN as stating that "[ $\mathrm{t}$ ]he most important for AMAN is how far REDD+ national Strategy in Indonesia gives opportunity to get what they have 
remains a nonbinding policy document, the advocacy efforts of these organizations has thus shifted to pressing for its application as well as lobbying for the integration of rights in the subnational REDD+ strategies being developed in several provinces. ${ }^{544}$ In January 2013, a coalition of forty-eight Indonesian NGOs, including AMAN and several regional branches of AMAN, called on the Indonesian government to implement the National REDD+ Strategy, arguing that: it "was prepared with an aim to improve Indonesian forest governance fundamentally and comprehensively," its preparation "was relatively transparent" and "involved relevant stakeholders," and that its comprehensive implementation would "respect the rights of indigenous peoples and local communities." 545 The fact that a wide coalition of Indonesian NGOs including IPOs and human rights NGOs would call for the implementation of the National REDD+ Strategy is perhaps the best indicator of the progressive manner in which this strategy recognizes and aims to protect the rights of Indigenous Peoples and local communities in the context of REDD+.

\subsubsection{Rights in the Development of Social and Environmental Safeguards for REDD+}

The development of social and environmental safeguards in Indonesia began at the end of 2010. It was triggered by the pressure exerted by Norway and domestic civil society actors as well as the adoption of the Cancun Agreements, which made them a necessary component of jurisdictional REDD+ readiness. ${ }^{56}$ The efforts to develop safeguards for REDD+ have unfolded in a fragmented manner, with the REDD+ Taskforce meant to be focusing on the

dreamt for a long time" and "REDD+ Task Force is thus far considered as government institution which is very close to indigenous peoples.")

544 Christopher Lang, "Interview with Bernadinus Steni, HuMa: 'REDD should be a way of supporting and strengthening the tenure of local communities and indigenous peoples that manage forests sustainably"' (17 April 2012), available at: www.redd-monitor.org/2012/04/17/ interview-with-bernadinus-steni-huma/ (accessed 18 November 2014); Bernadinus Steni, "Ha Masyarakay Atas Tanah dan Sumber Daya Alam Dalam Strategi REDD+" (HuMa, 2013) (on file with the author). See generally on the shift in focus of Indonesia's jurisdictional REDD+ readiness efforts: Caldecott et al., supra note 524 at 17-18; Indrarto et al., supra note 427 at 71 . AMAN et al., "Saving Indonesia's Remaining Forests Can No Longer be Delayed," available at: www.downtoearth-indonesia.org/sites/downtoearth-indonesia.org/files/Call\%2oto\% zosave \% zoforests-final.pdf (accessed 18 November 2014) at 2.

$54^{6}$ Bernadinus Steni and Nadia Hadad, "REDD+ Safeguards in Indonesia" (HuMa and Bank Information Center, March 2012), available at: www.bicusa.org/wp-content/uploads/2013/03/ REDD-Indonesia-Case-Study.pdf (accessed 20 November 2014) at 11-15; NORAD, supra note 492 at 100-101. See also Indonesian REDD+ Task Force, "REDD+ National Strategy" supra note 526 at 35 (providing that "[t]he development of an Information System for REDD+ Safeguards Implementation (SIS-REDD+) is a mandate of COP-16 UNFCCC.”) 
substance of the safeguards themselves and the Ministry of Forestry expected to take the lead in establishing an information system for reporting on the safeguards to international donors. As a result, the development of social and environmental safeguards has taken place through parallel processes and led to inconsistent outcomes. ${ }^{547}$

During 2011 and 2012, a multi-stakeholder working group of the REDD+ Taskforce developed a first draft of a policy for the Principles, Criteria, and Indicators for REDD+ Safeguards in Indonesia (known as PRISAI). These safeguards drew on several sources, including international human rights law and policy, the standards set by the Community, Climate \& Biodiversity Alliance, and relevant elements of Indonesian law. ${ }^{54^{8}}$ This initial draft was subsequently revised on the basis of consultations involving representatives from government, civil society, multilateral donors, and the private sector as well as the feedback gathered from four pilot projects that tested a preliminary version of the safeguards at the local level. ${ }^{549}$ This process resulted in a set of ten social and environmental safeguards that are meant to apply to all REDD+ activities, whether carried out at the jurisdictional or project level. ${ }^{50}$ The social safeguards included in principles 4 to 7 address the participatory and substantive rights of Indigenous Peoples and local communities. ${ }^{51}$ Principle 4 includes criteria and indicators that provide for the identification, recognition, and protection of the land and resource rights of Indigenous Peoples and local communities, including the requirement of the right to free, prior, and

547 In addition to these two efforts, there are a number of other processes that support the development of REDD+ safeguards in Indonesia. First, in Central Kalimantan, the Office of Environment of the Government of Central Kalimantan, the University of Palangkaraya, several local NGOs, and the Clinton Climate Initiative have produced a report providing local interpretation of REDD+ SES and have submitted it for adoption by the governor of Central Kalimantan. Second, the National Forest Council will be carrying out a SESA process in accordance with the FCPF requirements and thus assess its potential role in the eventual development of a full-fledged safeguards information system for REDD+. Third, the UN-REDD Programme has carried out multiple activities to develop and test protocols for respecting the right to free, prior, and informed consent (FPIC) of Indigenous Peoples and local communities in Central Sulawesi. For the most part, these various efforts have had little influence on the development of social and environmental safeguards at the national level (Interview 59 at 5 ; Interview 61 at 6-7).

$54^{8}$ Interview 59 at 2.

549 See Bernadinus Steni \& Iwan Wibisono, "Principles, Criteria and Indicator for REDD+ Safeguards Indonesia - PRISAI" (Bangkok, 6 March 2013) (on file with the author).

$55^{\circ}$ SATGAS REDD+, "Prinsip Kriteria dan Indikator Safeguards REDD+ Indonesia - PRISAI" (version 3.1) (May 2013) (on file with the author) at 5. This document is yet to be officially translated and all of the quotations below are translations of the original Indonesian document.

551 Ibid at 5 . 
informed consent in accordance with the UN Declaration of the Rights of Indigenous Peoples and mechanisms to resolve conflicts and address grievances in relation to land rights issues in the context of REDD+ activities. ${ }^{522}$ Principle 5 requires respect for the traditional knowledge, values, and rights of Indigenous Peoples and local communities and their integration into the design and implementation of REDD+ activities. ${ }^{553}$ Principle 6 mandates the full and effective participation of all stakeholders at all stages in the design, implementation, and evaluation of REDD+ activities, with a special focus on women and marginalized communities. ${ }^{54}$ Finally, Principle 7 provides for the equitable, transparent, and participatory sharing of the benefits of REDD+ among all rights holders and relevant stakeholders, based on their rights as well as their contribution to reductions in carbon emissions. ${ }^{555}$ All told, these social safeguards are largely consistent with the National REDD+ Strategy's expansive approach to the recognition and protection of the rights of Indigenous Peoples and local communities.

Further, in line with the requirements set by the UNFCCC COP at its sixteenth and seventeenth sessions in Cancun and Durban, the Ministry of Forestry has led efforts to develop a system for providing information on how social and environmental safeguards have been addressed and respected in the context of the implementation of REDD+ activities in Indonesia.556 Throughout 2011 and 2012, the Centre for Standardization and Environment of the Ministry of Forestry, with the bilateral assistance provided by the German government, led a process to prepare Principles, Criteria, and Indicators for a System for Providing Information on REDD+ Safeguards Implementation in Indonesia. The Centre for Standardization and Environment commissioned independent analysis of Indonesia's laws and their compatibility with the safeguards included in the Cancun Agreements, and organized an iterative series of national workshops, focus group discussions, and interviews with multiple stakeholders on various drafts and elements of such a system. ${ }^{557}$ The safeguards information system developed by the Centre for Standardization and Environment includes seven principles, seventeen criteria and thirty-two indicators that were developed on the basis of the guidance provided by the Cancun Agreements, relevant strands of Indonesian law, and the standards applicable under the Forest Stewardship Council and the World Bank Strategic

552 Ibid at 10-12. 553 Ibid at $13 . \quad 554$ Ibid at 14-15. 555 Ibid at 16.

556 Centre for Standardization and Environment, and Pusat Standardisasi Dan Lingkunkan, Principles, Criteria and Indicators for a System for Providing Information on REDD+ Safeguards Implementation in Indonesia (Jakarta, March 2013), available at: www.stane clime.org/ (accessed 31 December 2013) at 1.

557 Ibid at 2-29. 
Environmental and Social Assessment procedure. ${ }^{55^{8}}$ Of particular relevance to the rights of Indigenous Peoples and local communities are Principle 3 on the rights of "Indigenous and local communities" and Principle 4 on the effectiveness of stakeholder participation. Principle 3 includes criteria that provide that REDD+ activities shall "include identification of the rights of indigenous and local communities, such as tenure, access to and utilization of forest resources and ecosystem services, with increasing intensity at sub-national and site-level scales"; "include a process to obtain the free, prior, informed consent of affected indigenous and local communities before REDD+ activities commence"; "contribute to maintaining or enhancing the social economic wellbeing of indigenous and local communities, by sharing benefit fairly with them, including for the future generations"; and "recognize the value of traditional knowledge and compensate for commercial use of such knowledge where appropriate." 559 Principle 4 is comprised of criteria that aim to ensure that REDD+ activities "shall be based on proactive and transparent identification of relevant stakeholders, and the engagement of them in planning and monitoring processes, with an increasing level of intensity from national level to site level scales" and "include procedure or mechanisms for resolving grievances and disputes." 560

While these criteria would appear to provide an important recognition of participatory and substantive rights, this document is equivocal in its approach to the status and rights of Indigenous Peoples. First, although it uses the term Masyarakat adat, the English translation uses the term Indigenous communities, rather than Indigenous Peoples, raising questions regarding whether international protections accorded to the latter are intended to apply. Second, the document specifies in its glossary that "[o]n signing the UN Declaration on the Rights of Indigenous Peoples, Indonesia's Ministry of Foreign Affairs has clarified that the concept of 'indigenous peoples' in Indonesia must be interpreted on the basis that almost all Indonesians (with the exception of ethnic Chinese) are considered indigenous and thus entitled to the same rights" and that "the government has rejected calls for special treatment by groups identifying themselves as indigenous. ${ }^{161}$ This further suggests an unwillingness to recognize that Indigenous Peoples hold a particular status and set of rights under international law. Moreover, its glossary also provides an ambivalent definition of the right to FPIC, which is described in the following terms: "Free, Prior, and Informed Consent (or Consultation, per Government of USA and WB), a process that provides opportunity for indigenous and/or local communities to reject or approve activities in forests to which they have rights. ${ }^{562}$

$5^{8}$ Ibid at 10. $\quad 559$ Ibid at 34-35. $\quad{ }^{560} \quad$ Ibid at 35. $\quad 5^{61} \quad$ Ibid at 39. $\quad 5^{62} \quad$ Ibid at 38. 
As of August 2014, the National REDD+ Agency is moving forward with the development and coordination of a REDD+ safeguards information system. In doing so, it will need to reconcile some of the inconsistencies between the safeguards included in the PRISAI prepared under the auspices of the REDD+ Taskforce and those that are included in the SIS policy document drafted by the Centre for Standardization and Environment of the Ministry of Forestry. ${ }^{563}$ All told, the development of social and environmental safeguards for REDD+ reflect two broader trends in the relationship between the rights of Indigenous Peoples and local communities and the pursuit of jurisdictional REDD+ activities in Indonesia. For one, these two sets of safeguards aim to recognize and protect an expanded set of participatory and substantive rights for both Indigenous Peoples and local communities. For another, a comparison of the safeguards adopted by the REDD+ Taskforce and the Ministry of Forestry reveals the latter's reluctance to accord an extensive set of rights to Indigenous Peoples and local communities or to acknowledge the international protection accorded to them under international law.

\section{$3 \cdot 4$ EXPLAINING THE CONVEYANCE AND CONSTRUCTION \\ OF RIGHTS THROUGH JURISDICTIONAL REDD+ ACTIVITIES IN INDONESIA}

At the outset of Indonesia's jurisdictional REDD+ readiness efforts in 2008 and 2009, the policy documents developed by the Ministry of Forestry largely ignored the participatory and substantive rights of Indigenous Peoples. ${ }^{564}$ While this attracted significant criticism from domestic NGOs as well as the various international actors associated with the review and approval of an R-PP within the FCPF ${ }^{565}$ critical responses did not engender any immediate shifts in Indonesian policy. The clearest evidence that this initial pressure from below and from above had little immediate effect is that Indonesia strongly opposed the inclusion of any references to the rights of Indigenous Peoples in the Letter of Intent that it signed with Norway in May $2010^{566}$ and, moreover, failed to recognize Indigenous rights in the first draft National REDD+ Strategy that it released in September 2010. ${ }^{567}$

563 Interview 86 at $4 . \quad{ }^{6} 44$ IFCA, supra note $459 . \quad 565 \quad$ See fns. 486-489 above.

566 Letter of Intent, supra note 465 . See also Interview 39 at 4 ("Letter was written in a tough negotiation process. As you know, Indonesia hasn't recognized that it has Indigenous people so a lot of the references that we put in on the Norwegian side were taken out by Indonesia. There were several tough points in the negotiation and one of them was the rights of Indigenous people. We ended up with the compromise that both countries could live with. If it had a rights language we wouldn't have had the letter of intent.")

Indonesia National REDD+ Strategy (Draft 1), supra note 500. 
Although Norwegian officials failed to persuade Indonesian officials to change their policies with respect to Indigenous Peoples in the Letter of Intent itself, they did require that Indonesia ensure the full and effective participation of stakeholders (specifically including "Indigenous Peoples, local communities and civil society") in the design and implementation of REDD $+{ }^{568}$ In this context, Indonesian officials adopted legal norms relating to the full and effective participation of stakeholders as part of the Letter of Intent because the material benefits of obtaining funding exceeded the political costs associated with adopting these norms (cost-benefit adoption). ${ }^{569}$ This instrumentally motivated commitment opened the door for international and domestic actors to work closely with BAPPENAS to plan and hold a series of multi-stakeholder consultations regarding the development of a REDD+ strategy at the national and regional levels. ${ }^{57 \circ}$ In turn, the public release of the first National REDD+ Strategy in September 2010 provided an additional window for a coalition of Indonesian NGOs to advocate for the recognition and protection of the participatory and substantive rights of Indigenous Peoples and local communities. ${ }^{571}$ This advocacy paid immediate dividends, as the second draft National REDD+ Strategy released in November 2010 included new references to the term "Indigenous Peoples," emphasized the importance of their participation, and recognized the existence of the principle of FPIC..$^{52}$ This draft also recognized the problems associated with the lack of recognition of the land and resource rights of Indigenous Peoples and the need to resolve conflicts over land tenure as part of the domestic operationalization of REDD+. ${ }^{573}$ As was discussed above, the final version of Indonesia's National REDD+ Strategy as well as its safeguards policy built upon these initial gains in the recognition of the participatory and substantive rights of Indigenous Peoples, and even extended them to local communities. ${ }^{574}$

I argue that the conveyance of the rights of Indigenous Peoples and local communities in Indonesia's jurisdictional REDD+ readiness efforts can be primarily explained by the mobilization of domestic NGOs that succeeded in pressuring the National REDD+ Taskforce to enact these legal norms in its jurisdictional REDD+ policies. ${ }^{575}$ In their mobilization, these NGOs drew on

\footnotetext{
568 Letter of Intent, supra note 465 at $1 . \quad 569 \quad$ Interview 34 at 5; Interview 57 at 4.

570 Interview 93 at 2; Veierland, supra note 463 at 46-50. ${ }^{571}$ HuMa et al., supra note 508.

572 Indonesia National REDD+ Strategy (Draft 2), supra note 514 at $43-44$.

573 Ibid at 23 and 40.

574 REDD+ National Strategy (June 2012), supra note 527 at 18-28; Principles, Criteria, and Indicators for REDD+ Safeguards in Indonesia, supra note 550 at 10-16.

575 Interview 59 at 3; Interview 87 at 4 .
} 
the symbolic leverage provided by exogenous legal norms relating to the status and rights of Indigenous Peoples enshrined in the UN Declaration on the Rights of Indigenous Peoples and other key legal instruments applicable to REDD+, such as the World Bank's operational safeguards and the Cancun Agreements. ${ }^{576}$ The effectiveness of these advocacy efforts were also enhanced by the broad and well-connected nature of the coalition of Indonesian NGOs that emerged as important actors in Indonesia's jurisdictional REDD+ readiness efforts. For one, these NGOs represented or worked with both Indigenous Peoples and other forest-dependent communities, and emanated from Indonesia's human rights and environmental movements. ${ }^{577}$ For another, they received substantial financial support from international NGOs (particularly through funding provided by Norway to support civil society actors) $)^{578}$ and benefited from their participation in transnational networks focusing on advancing the rights of Indigenous Peoples and forest-dependent communities around the world. 579

In addition, these Indonesian NGOs were able to take advantage of the openings provided by the particular opportunity structure of the jurisdictional REDD+ readiness policy process in Indonesia. ${ }^{50}$ Specifically, they took advantage of the consultative and inclusive manner in which the REDD+ strategy and safeguards were developed, ${ }^{581}$ the reformist officials

$57^{6}$ Interview 59 at $2-3$.

577 See HuMa et al., supra note 508. See also Miriam Harjati Sanmukri, "Mobilities of Indigeneity: Intermediary NGOs and Indigenous Peoples in Indonesia” (2013) 7 Göttingen Studies in Cultural Property 115 at 121-124 (describing AMAN's collaboration with other NGOs in the context of REDD+ in Indonesia).

$57^{8}$ NORAD, supra note 423 at 293-296. 579 Interview 61 at 3; Interview 87 at 4 and 6-7.

${ }_{580}$ Interview 40 at 9. See particularly Interview 87 at 1 : "We are engaging with government in terms of making the policy for REDD+. That's how we see REDD+. It is our main goal is to use this opportunity ... because there is a window of opportunity to push forward for the recognition of rights of indigenous peoples. We politically engage in the process. For us, it is beyond carbon. We don't think about carbon at all. In terms of our political and engagement with the state, we see REDD issues opening up the ... broadening the windows of opportunity to engage with government."

${ }^{81}$ Interview 57 at 4; Interview 87 at 3; Lillegraven \& Sombolinggi, supra note 543. See also Rainforest Foundation Norway, "Supporting indigenous and forest-dependent peoples,' interests," available at: www.norad.no/en/support/climate-and-forest-initiativ-support-sche me/grants-2009-2012/_attachment/407553?_ts=141ee88geze\&download=true (accessed 16 December 2014) at 2: "Unlike similar processes in the past, the national REDD+ strategy was developed through a transparent process where civil society input was welcomed by the Government. (...) The process resulted in a REDD+ strategy that was well-received by most actors as it was open on several challenging issues such as free, prior and informed consent (FPIC), tenure, conflict, indigenous peoples and biodiversity. Decision makers now accept that these at times controversial issues need to be addressed if REDD+ is to succeed. An important achievement is that one of RFN's partners in Indonesia, the 
and experts that were appointed to the National REDD+ Taskforce, ${ }^{582}$ and the relative marginalization of the Ministry of Forestry as a policy actor..$^{583}$ Ultimately, the ability of domestic NGOs to mobilize and exert influence in the jurisdictional REDD+ readiness process spoke both to their skills and resources as intermediaries sitting at the intersections of Indonesian and international law as well as to the role played by exogenous actors in providing resources and creating openings that supported their mobilization..$^{84}$

While the mechanism of mobilization played a key role in triggering the conveyance of rights in Indonesia's jurisdictional REDD+ readiness efforts, the way in which these rights were eventually constructed in Indonesia's National REDD+ Strategy and its Principles, Criteria, and Indicators for REDD+ Safeguards can be best explained by the mechanism of persuasive argumentation. As a result of Indonesian government officials' participation in an extensive series of multi-stakeholder consultations and informal contacts with domestic NGOs throughout Indonesia over several years, ${ }^{55}$ internal discussions within the National REDD+ Taskforce and its drafting groups working on the REDD+ strategy and safeguards, ${ }^{586}$ and their ongoing dialogue with international interlocutors (particularly officials from Norway and other bilateral agencies, the UN-REDD Programme, the FCPF readiness mechanism, and other developing countries in Asia working on jurisdictional REDD+ readiness such as the Philippines), ${ }^{57}$ government officials developed and internalized a new norm about the appropriateness of respecting the rights of Indigenous Peoples and local communities in the

Community and Ecological Based Society for Law Reform (HuMa), helped draft the national REDD+ safeguards that cover issues such as rights, governance, transparency, benefit sharing and biodiversity. The safeguards are now adopted by the Government and have been included in the national REDD+ strategy." Interview 59 at 3; Interview 87 at $1-3$.

583 Interview 59 at 6 ; Interview 87 at 2 ; Interview 93 at 2 . The opportunities provided the relegation of the Ministry of Forestry in the development of policies for jurisdictional REDD+ readiness in Indonesia are perhaps most evident when one considers the many ways in which its various policy contributions with respect to REDD+ have tended to advance a more limited recognition of the rights of Indigenous Peoples and local communities. See, e.g., IFCA, supra note 459; Ministry of Forestry, supra note 523; Centre for Standardization and Environment and Pusat Standardisasi Dan Lingkunkan, supra note 556. Interview 59 at 3; Lillegraven \& Sombolinggi, supra note 543.

$5^{85}$ Interview 59 at 4; Interview 87 at 3; Interview 89 at 3. See also Monica Di Gregorio et al., "Equity and REDD+ in the Media: a Comparative Analysis of Policy Discourses" (2013) 18:2 Ecology E Society art. 39 at 10.

586 Interview 59 at 2 .

587 Interview 57 at 5 ; Interview 85 at 4 ; Interview 89 at 6; Interview 93 at 2. 
context of REDD+. ${ }^{58}$ The construction of this norm was most notably facilitated by the novelty of the pursuit of jurisdictional REDD+ efforts in Indonesia as well as the fact that several members of the National REDD+ Taskforce did not have a background in forestry (or for that matter in international law), ${ }^{58}$ which enabled them to be open to the development of new norms concerning the importance and extent of Indigenous rights in the context of REDD+. ${ }^{500}$

In addition, although international law only accords a distinctive and enhanced set of rights (such as the right to free, prior, and informed consent) to Indigenous Peoples, the outcomes of the jurisdictional REDD+ readiness process in Indonesia reflect the construction of a new shared understanding regarding the application of these exogenous legal norms to both Indigenous Peoples and local communities. In line with the Indonesian government's traditional reluctance to recognize the distinctive status of Indigenous Peoples (as it is understood under international law), exogenous legal norms relating to Indigenous rights were translated by Indonesian officials into hybrid legal norms that apply to masyarakat $a_{d a t^{591}}$ as well as to local communities. ${ }^{592}$ As such, the legal norms relating to the participatory and substantive rights of Indigenous Peoples and local communities in the context of Indonesia's jurisdictional REDD+ readiness efforts reveal the enduring influence of an endogenous norm ${ }^{593}$ that has acted as a barrier to the internalization of international norms that define Indigenous Peoples as holding a particular status and set of rights under international law.

Observations gathered through participation in the 19th session of the UNFCCC (Warsaw, Poland, November 2013); a design workshop for the UN REDD+ Academy (Jakarta, Indonesia, May 2014); a Meeting of the REDD+ Partnership (Palangkaraya, Indonesia, October 2013); and the 2oth session of the UNFCCC (Lima, Peru, December 2014). See also NORAD, supra note 423 at 295: "There has been a distinct shift in the discourse on Indigenous Peoples rights in Indonesia, some of which has been made possible through the activities supported by NICFI."

${ }^{8} 9$ Interview 85 at $7:$ "Forestry is a new issue for me. I'm not a forester. When I cam to this issue I see: wow, there is something wrong with the way this country is governed with this issue."

590 Interview 59 at 3 and 6-7; Interview 61 at 5 ; Interview 85 at 4 .

591 Although the English version of Indonesia's REDD+ policy documents uses the term "Indigenous Peoples," the Indonesian version uses the term masyarakat adat. Some Indonesian officials argue that these two terms are not equivalent and that the concept of Indigenous Peoples does not actually apply to Indonesia (Interview 87 at 2-3; Interview 89 at 5-6).

592 Interview 59 at 3. 593 Interview 87 at 2-3; Interview 89 at 5-6. 


\subsection{REDD+ AND THE FUTURE OF INDIGENOUS AND COMMUNITY RIGHTS IN INDONESIA}

This chapter has argued that the pursuit of jurisdictional REDD+ activities has resulted in the conveyance and construction of the rights of Indigenous Peoples and local communities in Indonesia. The process for developing a strategy and safeguards policy for jurisdictional REDD+ was shown to have provided a unique opportunity for Indigenous Peoples and other civil society actors to pressure the Indonesian government into recognizing the legitimacy of legal norms relating to Indigenous Peoples and their rights in the context of REDD+. The jurisdictional REDD+ policy-making process also led Indonesian officials to develop new hybrid legal norms that extended rights accorded to Indigenous Peoples under international law to all local communities. In a country that has traditionally not recognized the rights of Indigenous Peoples and other local communities in the context of its forest laws and policies, the emergence of these legal norms in Indonesia's National REDD+ Strategy and safeguards policy is nothing short of groundbreaking. In the words of two leading activists working on the rights of Indigenous Peoples and forest-dependent communities in Indonesia: "We would argue that more has been achieved in forest protection and the rights of indigenous peoples in Indonesia since the signing of the Indonesia-Norway agreement than over the course of the previous 15 years." ${ }^{\prime 594}$

The key question that remains is whether these newly recognized participatory and substantive rights will in fact be respected and implemented by the Indonesian government in the context of the operationalization of its jurisdictional REDD+ policies and institutions and, more broadly, within the field of forest governance. In particular, the fact that many government officials and politicians and other segments of Indonesian society have not wholeheartedly accepted these rights may limit their ability to lead to concrete improvements in the lives of Indigenous Peoples and local communities. One striking example of the broader set of views that exist with respect to the rights of Indigenous Peoples is the official statement made by the Indonesian Ministry of Affairs before the UN Human Rights Council in September 2012, which stated that "[g]iven its demographic composition, Indonesia, however, does not recognize the application of the indigenous people concept as defined in the UN Declaration on the Rights of Indigenous Peoples in the country." 595

595 Indonesia, "Views on conclusions and/or recommendations, voluntary commitments and replies presented by the State under review," Report of the Working Group on the Universal Periodic Review, UN Human Rights Council, 21st session (5 September 2012) UN Doc. A/ HRC/21/7/Add.1 at para. 6.3. 
Most importantly, the decision made by the administration of President Joko Widodo to close the National REDD+ Agency and to transfer responsibility for the implementation of the National REDD+ Strategy over to a newly amalgamated Ministry of Environment and Forestry may significantly encumber the concrete implementation of the rights of Indigenous Peoples and local communities, especially in terms of the recognition and protection of their community land tenure and forest rights. ${ }^{596}$ Indeed, given the manner in which the Ministry of Forestry has traditionally supported the agricultural, logging, and mining industries and its hesitant embrace of the rights of Indigenous Peoples and local communities in the context of REDD+, it is reasonable to expect that this decision may hamper efforts to clarify, recognize, and secure the forest tenure rights of local communities. ${ }^{597}$ As such, it is entirely possible that the ways in which the broader politics of land and forest governance have hindered the progress of several REDD+ projects as well as affected their capacity to strengthen community rights to land and forests may ultimately impede the implementation of the rights that have been enacted in Indonesia's policies for jurisdictional REDD+ readiness. ${ }^{598}$

All the same, there are several reasons to think that the recognition of rights in the context of jurisdictional REDD+ policies may ultimately have durable and significant effects. First, the recognition of rights in Indonesia's policies on jurisdictional REDD+ provides new opportunities and rhetorical tools for the mobilization of Indigenous Peoples and local communities around the protection of their rights. In fact, domestic Indonesian NGOs have already begun taking advantage of the gains achieved through REDD+ by, most notably, calling on the Indonesian government to implement the National REDD+ Strategy. ${ }^{599}$

Second, and perhaps most importantly, the emergence of rights in Indonesia's jurisdictional REDD+ readiness policies has fed into, and been accompanied by, broader legal and political developments in Indonesia. The most important such development is a landmark ruling of the Indonesian Constitutional Court in May 2013, which interpreted the Revised Forestry Law as providing that adat forests exist as a standalone form of forest tenure and are

${ }_{596}$ Rhett Butler, "Indonesia kills first-of-its-kind REDD+ Agency" (11 February 2015), available at: http://news.mongabay.com/2015/o2/indonesia-dissolves-agency-charged-with-forestry-refo $\mathrm{rm} /($ accessed 17 October 2015).

597 Interview 87 at $5 . \quad 598$ See Section 5.3.

599 Wajyudi \& Amir, supra note 543; AMAN et al., supra note 545. For an example of how Indonesian activists refer to REDD+ in their broader advocacy efforts relating to their rights, see, The Jakarta Post, “Govt urged to pass bill on indigenous people's rights” (23 March 2014), available at: www.thejakartapost.com/news/2014/03/23/govt-urged-pass-bill-indigenous-peo ple-s-rights.html (accessed 17 December 2014). 
therefore owned by masyarakat adat, rather than the State. ${ }^{600}$ There are a number of ways in which this ruling has been connected to the pursuit of REDD+ in Indonesia. ${ }^{601}$ In concrete terms, this ruling stemmed from a petition filed by AMAN, which was supported, in part, by funding provided by the Rainforest Foundation Norway as well as mapping conducted by the Samdhana Institute - both of which were financed by the Norwegian International Climate and Forests Initiative. ${ }^{602}$ While the Ministry of Forestry has been equivocal in its response to this constitutional ruling, the actors and institutions associated with the operationalization of jurisdictional REDD+ in Indonesia have served as a vehicle for its implementation. Indeed, in September 2014, nine government ministries and institutions launched a "National Programme for the Recognition and Protection of Customary Communities (PPMHA) through the REDD+ mechanism" that will be spearheaded by the National REDD+ Agency. ${ }^{603}$ To the extent that this program replicates many of the factors that contributed to the conveyance and construction of rights in the jurisdictional REDD+ policy-making process in the first place, it has significant potential for ensuring that the participatory and substantive rights of Indigenous Peoples and local communities are fully respected, protected, and fulfilled on the ground.

6oo Decision Number 35/PUU-X/2012, Constitutional Court of the Republic of Indonesia, 16 May 2013, available at: www.aman.or.id/wp-content/plugins/downloads-manager/upload/C onstitutional_Court_Ruling_16_May_2013.pdf (accessed 7 January 2014).

6or A number of Indonesian government officials will even go so far as to claim that the decision of the Constitutional Court was inspired by the example set by the National REDD+ Taskforce: Observations gathered during a Meeting of the REDD+ Partnership (Palangkaraya, Indonesia, October 2013).

602 NORAD, supra note 423 at 294.

603 The Samdhana Institute, "Nine Ministries-Institutions Agree to Launch National Programme for the Recognition and Protection of Customary Communities through REDD+," available at: www.samdhana.org/index.php/news-detail/nine-ministries-institu tions-agree-to-launch-national-programme-for-the-recognition-and-protection-of-customarycommunities-through-redd- (accessed 17 December 2014). 


\section{4}

\section{Rights and Jurisdictional REDD+ in Tanzania}

\subsection{FORESTS, GOVERNANCE, AND RIGHTS IN TANZANIA}

Forests make up 38 percent of Tanzania's land mass and represent 46 percent of the total forested area in all of East Africa. ${ }^{604}$ Although the majority of Tanzania's forest area comprises dry woodlands, it also includes other forest types such as humid mangrove forests and coastal woodlands that are rich in biodiversity. ${ }^{605}$ The forestry sector itself is not an important source of economic activity and timber products only amount to 1.9 percent of Tanzania's GDP. ${ }^{606}$ On the other hand, Tanzania's forests provide important habitats and wilderness areas for a range of animal species, help maintain soil fertility, limit soil erosion, landslides, and floods, and regulate water catchments and quality. ${ }^{607}$ These ecosystem services are essential for other important economic sectors, such as agriculture and tourism, and have been estimated to account for 10 to 15 percent of Tanzania's GDP. ${ }^{608}$ Forests are moreover critical to the livelihoods and cultural practices of rural and forestdependent communities, who depend on them for shelter, income, food, building materials, traditional medicines, and energy supply (in the form of charcoal and fuel wood). ${ }^{609}$ As a result, the forestry sector has long been at the heart of Tanzania's development policies ${ }^{610}$ as well as the aid programs

\footnotetext{
604 FAO, supra note 427 at 110.605 Burgess et al., supra note 142 at 341-343.

606 FAO, supra note 604 at 147.

$6 \circ 7$ World Bank, Putting Tanzania's Hidden Economy to Work: Reform, Management, and Protection of its Natural Resource Sector (Washington, DC: World Bank, 2008) at 16.

608 Ibid. 609 Ibid.

610 See, e.g., United Republic of Tanzania, Office of the Vice-President, National Strategy for Growth and Reduction of Poverty, 2005, at strategies 2.1.4, 2.10.1, and 4.7.2.
} 
delivered by international donors. ${ }^{611}$ Likewise, Tanzania's policy framework for forest governance recognizes the importance of forests in the alleviation of poverty and the pursuit of sustainable economic growth and development. ${ }^{612}$

Tanzania's vast forests have been characterized by high and unsustainable rates of deforestation and forest degradation in recent decades. ${ }^{613}$ Between 2005 and 2010, Tanzania lost 403,000 hectares of forest cover per year, corresponding to an annual loss of 1.16 percent of its total forest area ${ }^{614}$ and generating 122.14 million tons of carbon emissions on an annual basis. ${ }^{615}$ Given its relatively undeveloped rural economy, its reliance on agriculture, and the limited commercial potential of its dry woodland forests, the main causes of deforestation and forest degradation in Tanzania have been local in nature and have included the conversion of lands for agriculture, bio-fuel production, and human settlements; livestock grazing; firewood and charcoal production; uncontrolled wild fires; illegal logging and mining; and infrastructure development. ${ }^{616}$ The broader drivers of forest loss in Tanzania include the limited capacities of its government agencies to effectively manage forests and prevent the overexploitation of forest products and resources; its rapid population growth and the related environmental pressures that this creates; and the high levels of poverty among rural communities who depend on forests to meet their basic needs in terms of income, food, and energy. ${ }^{617}$ That said, forests managed by rural communities under Tanzania's advanced regime for participatory forest management have been characterized by lower

61 See, e.g., Tanzania Development Partners Group, "The Large and Uncaptured Potential of the Forestry Sector in Developing Tanzania's Economy" (2005), available at: www.tzonline .org/pdf/thelargeanduncapturedpotentialoftheforestry.pdf (accessed 7 October 2014).

612 Tanzania's National Forest Policy aims to "enhance the contribution of the forest sector to the sustainable development of Tanzania and the conservation and management of her natural resources for the benefit of present and future generations" (United Republic of Tanzania, Ministry of Natural Resources and Tourism, National Forest Policy, 1998, at 14) and its National Forest Programme aims "to reduce poverty and increase economic growth by managing forests sustainably without compromising environmental and cultural values" (United Republic of Tanzania, Ministry of Natural Resources and Tourism, Forestry and Beekeeping Division, National Forest Programme in Tanzania 2001-2010, 2001, at Section 1.2).

613 Fabiano L. Godoy, "Deforestation and $\mathrm{CO}_{2}$ emissions in coastal Tanzania from 1990 to 2007 " (2011) 39(1) Environmental Conservation 62.

614 FAO, supra note 604 at 110 .

${ }_{15}$ United Republic of Tanzania, Office of the Vice President, National Strategy for Reduced Emissions from Deforestation and Forest Degradation (REDD+) (March 2013) (on file with the author) at 36 .

616 Ibid. at 13-15. See also Simon Milledge, Ised Gelvas \& Anyje Ahrends, Forestry, Governance and National Development: Lessons, Learned from a Logging Boom in Southern Tanzania (TRAFFIC East/Southern Africa, 2007) at 32-35.

617 Tanzanian National Strategy for REDD+, supra note 615 at 15-16. 
rates of forest loss, as compared to forests managed by central authorities or those with an open-access status. ${ }^{618}$ Given that the forests under the direct management of communities only amount to 13 percent of Tanzania's total forest area, the provision of funding and capacity-building to support communities in securing and governing forests has thus long been identified as a promising intervention for reducing deforestation in Tanzania. ${ }^{619}$

The management of land and forests was heavily centralized in Tanzania ${ }^{620}$ during British colonial rule with the adoption of laws and policies that prioritized the statutory rights of colonial settlers over the customary rights accorded to Tanzanians ${ }^{621}$ and asserted control over forests, wildlife, and natural resources by establishing protected areas from which rural and forestdependent communities were evicted and barred entry. ${ }^{622}$ For the first few decades after independence, the authoritarian socialist regime of Julius Nyerere pursued a similarly coercive approach to land and resource governance. It expanded the number and scope of protected areas ${ }^{623}$ as well as implemented a policy of large-scale villagization (ujaama vijijini) that involved the forcible resettlement and concentration of rural Tanzanians into planned villages and the establishment of agricultural cooperatives. ${ }^{6} 4$ While this program gave newly formed village settlements the authority to manage land and allocate rights of occupancy within their borders, villagers themselves lacked statutory rights to land and enjoyed very little security of

land Tanzania.

621 gave village chiefs the power to allocate customary rights to land to villagers. This regime of customary property law not only disregarded existing communal practices, but also provided villagers with insecure and weak rights that could be overridden and reallocated for other purposes by colonial authorities. See Elke Grawert, Departures from Post-Colonial Authoritarianism. Analysis of System Change with a Focus on Tanzania (Frankfurt, Germany: Peter Lang, 2009) at 193-194.

${ }_{22}$ Fred Nelson et al., "Community-Based Conservation and Maasai Livelihoods in Tanzania" in Katherine Homewood et al., Staying Maasai? Livelihoods, Conservation and Development in East African Rangelands (New York, NY: Springer, 2009) 299 at 301-303.

${ }^{623}$ Ibid at 303-305. 624 Grawert, supra note 621 at 202-205. 
tenure as a result. ${ }^{625}$ The resulting ambiguities around unclear and overlapping land rights, the lack of recognition of customary land rights and practices, and ongoing tensions over the management of natural resources and the exclusion of rural communities from forest and nature reserves generated a series of protracted conflicts over land between various actors of Tanzanian society. ${ }^{626}$

In the second half of the 1980 , in response to an economic crisis and the pressures exerted through the structural adjustment programs imposed by multilateral donors, Tanzania began to transition away from socialist policies to adopt liberal economic policies and forms of governance. ${ }^{627}$ This broader trend toward political decentralization coincided with greater interest among donors as well as Tanzanian officials in experimenting with community-based approaches to forest management in the early 1990s. ${ }^{628}$ Finally, the extensive discontent with land conflicts and tenure insecurity led the reformist government of Ali Hassan Mwinyi to appoint a commission of inquiry on land matters. ${ }^{629}$ These efforts eventually culminated in the adoption of three laws, the Land Act and the Village Land Act in 1999 and the Forest Act in 2002, which provide the foundations for rural communities to govern their lands and manage their forests in contemporary Tanzania.

The Land Act provides that all land is held in trust by the President on behalf of all citizens ${ }^{630}$ and recognizes three categories of land: reserved land, village land, and general land. ${ }^{631}$ Reserved land is land that is set aside by the central government for the purposes of conservation or development under national laws and ordinances, such as national parks, land for public utilities, and wildlife reserves. ${ }^{62}$ Village land is land managed by Village Councils on behalf of Village Assemblies that falls within the demarcated boundaries of villages that have obtained formal certificates for this purpose as well as land that villages have been occupying or using for twelve or more years under customary law. ${ }^{63}$ Village Councils may further demarcate village land into three sub-categories: communal land jointly used by villagers (such as pastures or forests); occupied

Patrick McAuslan, Land Law Reform in East Africa: Traditional or Transformative? (Abingdon, UK: Routledge, 2009) at 50-55.

626 Grawert, supra note 621 at $205-212,226-232$, and $512-534 . \quad{ }^{627}$ Ibid at $234-243$.

${ }_{628}$ Fred Nelson \& Tom Blomley, "Peasants' Forests and the King's Game? Institutional Divergence and Convergence in Tanzania's Forestry and Wildlife Sectors" in Fred Nelson, ed., Community Rights, Conservation and Contested Land: The Politics of Natural Resource Governance in Africa (Abingdon, UK: Routledge, 2012) 79 at 85-88. See also Liz Alden Wily \& Peter A. Dewees, "From users to custodians: Changing relations between people and the State in forest management in Tanzania" (World Bank Policy Research Paper 2569, 2001).

629 McAuslan, supra note 625 at 95-98. $\quad 6_{30} \quad$ Land Act, art. 4(1). $\quad 6_{31} \quad$ Ibid, art. 4(4).

$6_{32}$ Ibid, art. 6(1). ${ }_{33}$ Village Land Act, art. 7(1). 
land used and managed by individuals or groups; and future land set aside for future use by villagers. ${ }^{6}{ }^{64}$ Villagers can gain rights to occupied land through either a granted right of occupancy obtained from Village Councils that is subject to a designated lease period of a maximum of 99 years ${ }^{635}$ or a customary right of occupancy that may be held indefinitely. ${ }^{636}$ Finally, general land is public land that does not constitute reserved land or village land. ${ }^{67}$ Tanzania's land tenure system thus provides a clear legal basis for rural communities to exercise statutorily and customarily defined rights to manage, occupy, and use land within the boundaries of villages. On the other hand, the exercise of customary land rights claimed by communities on reserved or general lands has received less recognition and protection from central authorities and has moreover given rise to continued land disputes and conflicts between communities. ${ }^{638}$

The Forest Act enables communities living in or adjacent to forests to control and manage or co-manage their forests through one of two mechanisms: Community-Based Forest Management (CBFM) and Joint Forest Management (JFM). The provisions on CBFM most notably allow villages to establish and manage, whether separately or jointly, a Village Land Forest Reserve (VLFR). ${ }^{6} 9$ In order to do so, a village must establish that it holds tenure over a given forest, prepare a plan for its sustainable management, and adopt by-laws that support this plan (through the provision of fines or sanctions, for instance). The plan and the by-laws must then be ratified by the District Council, who can then declare the existence of a new VLFR. After three years, villages may moreover apply for their VLFR to be gazetted by the central government. ${ }^{64^{\circ}}$ The creation of a VLFR provides local communities with clear and unambiguous statutory rights to manage and control forests and fully benefit from their resources, in line with their approved VLFR management plan. ${ }^{64}$ As is recognized by the Tanzanian Ministry of Natural Resources \& Tourism, CBFM thus "aims to secure forests through sharing

$6_{34}$ Ibid, art. 12-13. $6_{35}$ Land Act, art. 22. $6_{36}$ Village Land Act, art. 18.

${ }_{37} \mathrm{Ibid}$, art. 1(2). In fact, this definition is not consistent with the one included in article 4(c) of the Land Act, which defines general land as "all land which is not reserved land or village land and includes any unoccupied or unused village land." This inconsistency creates significant ambiguity about the scope and security of unoccupied or unused village lands (Peter G. Veit, Darryl Vhugen \& Jonathan Mine, "Threats to Village Land in Tanzania Implications for REDD+ Benefit-Sharing Arrangements" in Lisa Naughton-Treves \& Cathy Day, eds., Lessons about Land Tenure, Forest Governance and REDD+: Case Studies from Africa, Asia and Latin America (Washington, DC: USAID, 2012) 11 at 14).

${ }_{63} 8$ USAID, "USAID Property Rights and Resource Governance Country Profile: Tanzania" available at: http://usaidlandtenure.net/sites/default/files/country-profiles/full-reports/USAI D_Land_Tenure_Tanzania_Profile.pdf (accessed 8 October 2014) at 10 and 14-15.

639 Forest Act, art. $32 . \quad{ }_{40}^{\circ}$ Blomley \& Iddi, supra note 144 at 12-14.

${ }_{41}$ Nelson \& Blomley, supra note 628 at 83 . 
the rights to control and manage them, not just the right to use or benefit from them" and "targets communities not as passive beneficiaries but as forest managers." ${ }^{642}$ In contrast, JFM entails the adoption of joint forest management agreements between communities and the central government and does not therefore provide communities with additional statutory rights to govern forests or to access their benefits. ${ }^{6}{ }^{43}$

As of 2009, 1,460 villages (14 percent of all villages on mainland Tanzania) had engaged in CBFM and 395 forests had been declared or gazetted as VLFRs, thus placing 12 percent of unreserved forests under the direct control and authority of local communities. ${ }^{644}$ However, local communities have also faced a number of challenges in the establishment and management of VLFRs, including their limited capacity to protect VLFRs from exploitation by outsiders participating in the growing trade in illegal timber. This has been compounded by the reluctance of some District Council officials to declare a new VLFR due to the potential loss of revenue (in the form of taxes and levies on the exploitation of forests or bribes or kickbacks received as part of their participation in illegal logging) that may result therefrom. These practical challenges have thus prevented many local communities from taking full advantage of Tanzania's advanced CBFM regime. ${ }^{645}$

The experience of local communities pales in comparison with the setbacks faced by Indigenous Peoples seeking recognition and protection of their customary lands and forests. Four ethnic communities identify as Indigenous Peoples in contemporary Tanzania: forest-dwelling hunter-gatherers known as the Hadzabe and the Akie and pastoralists known as the Maasai and the Barabaig. ${ }^{6}{ }^{6}$ Throughout the twentieth century, these communities experienced ill-treatment, discrimination, and deprivation at the hands of the German and British colonial authorities as well as the post-colonial government of Nyerere. They were evicted, frequently through force, from their traditional lands and forests to make way for the creation of forest and nature reserves and thereafter subjected to coercive regimes of wildlife and resource management that adversely affected their traditional livelihoods and cultural practices. Their lands, forests, and grazing tracts were also alienated to commercial and private

United Republic of Tanzania, Ministry of Natural Resources and Tourism, Forestry and Beekeeping Division, Community-Based Forest Management Guidelines for the establishment of Village Land Forest Reserves and Community Forest Reserves (2007) at 2.

643 Forest Act, art. 16. ${ }^{644}$ Blomley \& Iddi, supra note 144 at 19.

645 Nelson \& Blomley, supra note 628 at 89-91.

${ }^{6} 46$ See International Fund for Agricultural Development (IFAD), "Country Technical Note on Indigenous Peoples' Issues: The United Republic of Tanzania” (June 2012), available at: www.ifad.org/english/indigenous/pub/documents/tnotes/tanzania.pdf (accessed 8 October 2014) at 5-7. 
interests, without their consent or receipt of any compensation. And their traditional systems of customary law and governance were disrupted through the imposition of external legal and administrative structures (such as the bifurcated property rights regime of the British or the villagization program of the Nyerere regime). ${ }^{647}$

During the 1980 s, members of the Maasai and Barabaig communities filed a number of lawsuits against the Tanzanian government and corporations that had dispossessed them of their lands. However, their attempts to gain recognition and restoration of their customary land rights before the Tanzanian courts were ultimately unsuccessful. ${ }^{648}$ In the early 1990s, these communities began to establish links with, and draw inspiration from, the global Indigenous movement originating in Canada, Australia, and Latin America. They began to identify as Indigenous and formed a series of NGOs to advocate for the recognition of their status and rights as Indigenous Peoples. ${ }^{649}$ In 1994, these NGOs most notably established a new umbrella organization known as Pastoralist and Indigenous NGOs (PINGOs) to serve as a "loose coalition of like minded pastoralist and hunter/gatherer community based organisations." "550 With support from international donors, these NGOs sought to take advantage of the opportunities offered by the gradual liberalization of Tanzanian politics to press for the protection of their rights as Indigenous Peoples, especially in terms of their traditional rights to land. ${ }^{651}$ Nevertheless, the effectiveness of Tanzania's fledgling Indigenous movement has been limited due to its disjointed and disorganized nature as well as its detachment from the communities that it is meant to serve, and it has made few legal or political gains over the last two decades. ${ }^{652}$

For one, the Hadzabe, Akie, Maasai, and Barabaig have not succeeded in being recognized as "Indigenous" by the Tanzanian government. Although Tanzania voted in favor of the UN Declaration on the Rights of Indigenous Peoples in 2007, it has not acknowledged the existence of Indigenous Peoples on its territory nor has it adopted any national laws or policies that aim to

Nelson et al., supra note 622 at 301-304; Albert Kwokwo Barume, Land Rights of Indigenous Peoples in Africa (Copenhagen, Denmark: IWGIA, 2010) at 138-142.

Ibid at $123-13^{8}$.

Jim Igoe, "Scaling Up Civil Society: Donor Money, NGOs, and the Pastoralist Rights Movement in Tanzania" (2003) 34(5) Development and Change 863; Jim Igoe, "Becoming Indigenous Peoples: Difference, Inequality, and the Globalization of East African Identity Politics" (2006) 105/420 African Affairs 399.

Ibid at 415. $\quad{ }_{51}$ Igoe, "Scaling Up Civil Society" supra note 649.

Dorothy L. Hodgson, "Precarious Alliances: The Cultural Politics and Structural Predicaments of the Indigenous Rights Movement in Tanzania" (2002) American Anthropologist 1086; Igoe, "Scaling Up Civil Society" supra note 649. 
recognize or protect the rights of Indigenous Peoples. ${ }^{63}$ While recognizing that some ethnic groups may need "special protection," the Government of Tanzania has maintained that all Tanzanians are "Indigenous." ${ }^{5} 4$ This position goes against an explicit recommendation adopted by the African Commission on Human and Peoples' Rights (ACHPR) calling on Tanzania to "[f]ormulate a definition of indigenous peoples that accommodates Tanzania's circumstances and is consistent with the provisions and principles of the African Charter." ${ }^{255}$ The nonrecognition of Indigenous Peoples has been widespread across other segments of Tanzanian society that have viewed their traditional lifestyles as incompatible with the "modern" values of contemporary Tanzania. ${ }^{656}$ Indigenous Peoples have thus experienced systematic discrimination as well as political and socioeconomic marginalization not only due to the policies of

653 Elifuraha Isaya Laltaoka, "Indigenous Peoples' Rights in Tanzania and International Rights Law” (2012) 1(1) TUMA Law Review 147.

654 Human Rights Council, Working Group on the Universal Periodic Review, "Report of the Working Group on the Universal Periodic Review: United Republic of Tanzania” UN Doc. A/HRC/19/4 (2011) at para. 24.

655 ACHPR, "Concluding Observations and Recommendations on the Consolidated 2nd to 1oth Periodic Report of the United Republic of Tanzania," 43rd Ordinary Session, 7-22 May 2008, Ezulwini, Kingdom of Swaziland, available at: www.achpr.org/files/sessions/43rd/conc-obs/ 2to10-1992-2008/achpr43_conc_staterep2to1o_tanzania_2008_eng.pdf (accessed 6 February 2015) at para 37. In this regard, it is worth emphasizing that the ACHPR has endorsed the report drafted by a working group on Indigenous Populations and Communities in Africa, which recognizes the value and application of the concept of Indigenous Peoples in the African context: "The overall conclusion is that indigenous peoples and communities in Africa suffer from a number of particular human rights violations that are often of a collective nature; that the African Charter is an important instrument for the promotion and protection of the rights of indigenous peoples and communities; and that the preceding jurisprudence of the African Commission opens a way for indigenous peoples and communities to seek protection of their human rights. The report further concludes that, although contested, the term 'indigenous peoples' is valuable also in an African context as it offers the victims of particular human rights abuses an important avenue forward to improve their situation. (...) Unlike other indigenous peoples outside Africa, where the aboriginal type of indigeneity is the characteristic feature, Africa's indigenous peoples have their own specific features that reflect from the specific feature of the African state and its role. They have specific attachment to their land and territory; they have specific cultures and mode of production that are distinct from the groups that dominate political, economic and social power. As predominantly traditional systems, they have their own forms of governance, laws that go in the name of customary laws, modes of productions and culture, all deriving from an all-inclusive indigenous knowledge system" (Report of the African Commission's Working Group of Experts on Indigenous Populations/Communities. Submitted in accordance with the "Resolution on the Rights of Indigenous Populations/Communities in Africa," adopted by The African Commission on Human and Peoples' Rights at its 28th ordinary session (Eks/Skolens Trykkeri and Copenhagen, Denmark: ACHPR and IWGIA, 2005) at 106-107). IFAD, supra note 646 at 10-13. 
the Tanzanian government, but also due to the actions of the private sector, conservation actors, and rural communities. ${ }^{657}$

In addition, Indigenous Peoples have, by and large, not benefited from land and forest reforms adopted in Tanzania in the late 1990 and early zooos. ${ }^{6.8}$ While some Indigenous communities in Tanzania have sought to establish customary rights of occupancy on their traditional lands under the Land Act and the Village Land Act, this option has remained riddled with a number of legal and bureaucratic obstacles, particularly their exclusion from the village-based unit of political administration and governance. ${ }^{659}$ As such, most of the customary lands of Indigenous Peoples have been declared as reserve lands (particularly conservation or wildlife areas) or village lands (established during the ujaama vijijini era). ${ }^{660}$ Indigenous Peoples have continued to face significant barriers in claiming and exercising their land and tenure rights, as well as eviction from their lands, pastures, and grazing areas. ${ }^{661}$ The tenure insecurity that Indigenous Peoples face in Tanzania is all the more harmful since access to land and its resources is integral to their livelihoods and cultural practices.

\subsection{THE PURSUIT AND GOVERNANCE OF JURISDICTIONAL REDD+ IN TANZANIA}

The commencement of jurisdictional REDD+ activities in Tanzania originates in the conclusion of a bilateral agreement in April 2008 with the government of Norway that established a "Climate Change Partnership with a focus on REDD." ${ }^{662}$ The original impetus for this agreement came largely from the Norwegian Embassy in Dar es Salaam and built on Norway's longstanding support for forest conservation and governance in Tanzania. ${ }^{663} \mathrm{In}$

IFAD, supra note 646 at $8-25$. See generally Human Rights Council, Working Group on the Universal Periodic Review, "Summary prepared by the Office of the High Commissioner for Human Rights in accordance with paragraph 15 (c) of the annex to Human Rights Council resolution 5/1. United Republic of Tanzania" UN Doc. A/HRC/WG.6/12/TZA/3 (2011) at para. 61-66.

Barume, supra note 647 at $142-145$.

659 Two obstacles are that Indigenous lands are not physically occupied by households on a permanent basis and that many Indigenous communities do not have enough members to form a village under Tanzanian law. IFAD, supra note 646 at 14 . Barume, supra note 647 at 145-151; IFAD, supra note 646 at 13-14.

Elifuraha Isaya Laltaoka, "Pastoralists' Right to Land and Natural Resources in Tanzania" (2013) 15 Oregon Review of International Law 43.

662 Royal Norwegian Embassy in Dar es Salaam, "Letter of Intent between the United Republic of Tanzania and the Kingdom of Norway on a Climate Change Partnership with focus on REDD” (2008) (on file with the author).

663 Interview 16 at 3-4; Interview 44 at 4 ; Interview 65 at 1. 
this early period in the emergence of REDD+ within the UNFCCC and around the world, Norwegian officials believed that supporting the operationalization of REDD+ in Tanzania could be used to demonstrate its potential role in contributing to the alleviation of poverty as well as its applicability in the dry woodlands that are common in much of sub-Saharan Africa. ${ }^{664}$ In turn, Norway's interest in funding the implementation of REDD+ in Tanzania garnered significant interest both from the Tanzanian Vice President's Office, which handles environmental issues and climate change, as well as the Tanzanian Ministry of Natural Resources and Tourism, which oversees the management and governance of forests. ${ }^{665}$ Tanzanian officials saw the pursuit of REDD+ readiness activities as an opportunity to take advantage of new funds to improve Tanzania's forest management practices, contribute to poverty alleviation, and make a voluntary contribution to global climate mitigation efforts. ${ }^{666}$

Pursuant to its bilateral partnership with Norway, Tanzania created a National REDD+ Taskforce bringing together six senior government officials from the Office of the Vice-President (Division of the Environment) and the Ministry of Natural Resources and Tourism (Forestry and Beekeeping Division) to coordinate its jurisdictional REDD+ readiness efforts in late 2008. ${ }^{667}$ In addition, Tanzania also established a REDD+ Secretariat, hosted at the Institute of Resource Assessment (IRA) of the University of Dar es Salaam, ${ }^{668}$ which was given the important task of receiving and administering the funding provided by Norway for the creation of a national REDD+ strategy. The establishment of this secretariat in a third-party institution outside of government was motivated by Norway's lack of confidence in the ability of the MRNT to manage donor funds, in light of a corruption inquiry that was unresolved at the time. In addition, Norwegian and Tanzanian officials also shared an interest in finding a neutral platform that could facilitate the development of a national REDD+ strategy in a context where the MRNT and VPO were unable to agree as to who should hold primary responsibility for coordinating REDD+ readiness efforts. ${ }^{669}$

\footnotetext{
664 Interview 15 at 8; Interview 44 at 4 ; Interview 52 at $1-2$.

665 Interview 19 at 1 ; Interview 21 at 1 ; Interview 22 at 1.

666 Interview 15 at 8; Interview 19 at 3; Interview 21 at 1; Interview 22 at 1 . See also Salla Rantala \& Monica Di Gregorio, "Multistakeholder environmental governance in action: REDD+ discourse coalitions in Tanzania” (2014) 19(2) Ecology \& Society article 66 at 5.

$66_{7}$ REDD+ Secretariat, “Tanzania REDD Initiative Newsletter” Issue 1, August 2009 (on file with the author) at 6-7.

668 Institute of Resource Assessment, University of Dar es Salaam, "Facilitation for the Preparation of a National REDD Strategy in Tanzania, proposal submitted to the Royal Norwegian Embassy in Tanzania” (2 March 2009) (on file with the author) at 4.

669 Interview 15 at 8; Interview 20 at 1; Interview 52 at 3 ; Interview 65 at 1.
} 
From 2009 to 2014, Norway disbursed 58 million US dollars for the implementation of three types of REDD+ readiness activities in Tanzania. First, Norway provided more than 7 million US dollars to fund the preparation of a national REDD+ strategy. Second, Norway provided close to 30 million US dollars to support the development and operationalization of nine REDD+ pilot projects across Tanzania. ${ }^{670}$ Third, it spent over 21 million US dollars to fund two major research, training, and infrastructure programs in collaboration with the Sokoine University of Agriculture, one focusing on climate change impacts, adaptation, and mitigation (CCIAM) and another supporting the development of a national system for the measurement, reporting, and verification (MRV) of forest carbon stocks. ${ }^{671}$ Norway's support for these various activities created momentum, generated knowledge, and increased capacity for the pursuit of REDD+ in Tanzania. ${ }^{672}$ Yet, despite the important role that Norway played in the inception and funding of REDD+ in Tanzania, ${ }^{673}$ Tanzanian officials pursued their REDD+ readiness activities in a relatively autonomous fashion. ${ }^{674}$ Indeed, Norwegian officials aimed to foster Tanzanian ownership of REDD+ and thus sought to influence REDD+ readiness efforts through dialogue rather than through the use of conditionality or overt political pressure. ${ }^{675}$

In addition to the bilateral support provided by Norway, Tanzania received close to four million US dollars in assistance from a dedicated UN-REDD National Programme for its jurisdictional REDD+ readiness efforts. ${ }^{6}{ }^{6}$ From

670 These pilot projects are discussed in Section 5.4.

${ }_{671}$ NORAD, supra note 423 at 308-309. ${ }^{672}$ Ibid at 318, 321-322.

673 In addition to its bilateral program, Norway also served as the primary donor of the UNREDD Programme and the development of an R-PP for the FCPF in Tanzania. See NORAD, "Real-Time Evaluation of Norway's International Climate and Forest Initiative Contributions to National REDD+ Processes 2007-2010 Country Report: Tanzania” (March 2011), available at: www.norad.no/en/tools-and-publications/publications/evaluations/publi cation/_attachment/333469?_download=true\&_ts=12fgbe $7412 \mathrm{~d}$ (accessed 14 October 2014) at 40 .

674 Interview 16 at 7 ; Interview 20 at 7 .

675 Interview 15 at 9-10; Interview 20 at 7 . Perhaps the best illustration of Norway's lack of control over the jurisdictional REDD+ readiness process in Tanzania was the fact that representatives from the Norwegian Embassy were unable to participate (due to last-minute invitations) in the meetings of Tanzania's National REDD+ Taskforce after May 2012 and did not receive copies of final REDD+ policy documents in a timely fashion in the final stages of the finalization of the national REDD+ strategy (see Nordeco \& Acacia, National REDD Policy Project in Tanzania, End-of-Project Review, Final Report, 25 February 2014 (on file with the author) at 9).

${ }_{676}$ Multi-Partner Trust Fund Office, "UN-REDD Programme - Tanzania Quick Start Initiative," available at: http://mptf.undp.org/factsheet/project/00073511 (accessed on 6 January 2013). 
2009 to 2013 , this program provided funding, capacity-building, and technical assistance in order to support the design of a national governance framework for REDD+, the development of a national MRV system, the effective implementation of REDD+ at district and local levels, and the generation of a broad consensus among multiple stakeholders for the pursuit of REDD+ in Tanzania. ${ }^{677}$ Apart from its important role in providing technical support for developing Tanzania's MRV capabilities, the influence of the UN-REDD Programme on Tanzania's REDD+ readiness efforts was limited, however. For one, Tanzania had already initiated the development of its national REDD+ strategy with support from Norway by the time the National UN-REDD Programme was operational and officials from the UN-REDD Programme struggled to ensure that their work was relevant to Tanzania's ongoing efforts on REDD+ readiness. ${ }^{678}$ For another, the availability of funding from Norway and the few strings attached made it possible for Tanzanian officials to dismiss the advice and knowledge products provided by the UN-REDD Programme. ${ }^{679}$

Finally, Tanzania submitted an R-PP to the World Bank FCPF in 2010 that was subsequently approved by the World Bank FCPF in $2011 .{ }^{680}$ Although it went through the exercise of preparing and submitting an R-PP to the FCPF, Tanzania did not seek funding from the FCPF Readiness Mechanism as such and used its membership within the FCPF Participant's Committee as an opportunity to stay engaged in international discussions of REDD+ as well as to learn from the experience of other developing countries pursuing REDD+ readiness efforts. ${ }^{681}$ Tanzania did not receive direct technical support and assistance from the FCPF as such, and the FCPF exerted little influence on the design and implementation of Tanzania's jurisdictional REDD+ readiness efforts. ${ }^{682}$

UN-REDD Programme, "UN-REDD Programme - Tanzania Quick Start Initiative" (December 2009) (on file with the author) at 39-42.

${ }_{67} 8$ Interview 8 at $7-8$. See also Nordeco \& Acacia, supra note 675 at 17.

679 Interview 8 at 8 ; Interview 19 at 3 ; Interview 20 at $7-8$. See also Gapare \& William, supra note 749 at 7 and 46 .

680 FCPF, "REDD Readiness Progress Sheet: Tanzania, March 2012," available at: www.forest carbonpartnership.org/sites/forestcarbonpartnership.org/files/Documents/PDF/Marzo12/RE DD\%20Tanzania\%zoFact\%2oSheet_March\%202012_o.pdf (accessed 14 October 2014).

681 Interview 19 at 2; Interview 20 at 8. See also NORAD, supra note 426 at 308; FCPF, "REDD Readiness Progress Fact Sheet," available at: https:/forestcarbonpartnership.org/sites/fcp/ files/2014/August/FCPF\%zoCountry\%zoProgress\%zofact\%zoSheet\%zoAugust\%zozo14-Tanz ania.pdf (accessed 7 October 2014) at 1.

682 Nordeco \& Acacia, supra note 675 at 18 ; NORAD, supra note 423 at 325 . This is most notably reflected in the fact that Tanzania's National REDD+ Strategy does not follow the template set by the FCPF as well as in Tanzania's decision not to undertake a SESA. 


\subsection{THE RIGHTS OF INDIGENOUS PEOPLES AND LOCAL \\ COMMUNITIES IN JURISDICTIONAL REDD+ READINESS ACTIVITIES IN TANZANIA}

\subsubsection{Rights in the National REDD+ Strategy}

The National REDD+ Taskforce initiated Tanzania's jurisdictional REDD+ readiness activities in January 2009 with a four-day multi-stakeholder planning workshop and a series of field trips to Australia, Norway, and Brazil in May and June 2009. ${ }^{683}$ In August 2009, it launched a National REDD Framework that identified the key elements of jurisdictional REDD+ readiness that Tanzania would aim to achieve and offered a multi-year roadmap for the development of a national REDD+ strategy. ${ }^{64}$ This framework recognized the potential adverse implications of REDD+ for the rights of Indigenous Peoples and local communities as well as the benefits their engagement might bring in the creation and implementation of a national REDD+ strategy. ${ }^{685}$ In particular, Tanzania's National REDD Framework identified enhanced support for participatory forest management as a potential pathway for reducing carbon emissions in Tanzania ${ }^{686}$ as well as recognizing the critical importance of secure land tenure and community rights for the sustainable management of forests. ${ }^{687}$

From August to October 2009, the National REDD+ Taskforce undertook an initial series of consultations on the development of a national REDD+

See REDD+ Secretariat, “Tanzania REDD Initiative Newsletter” Issue 2, January 2010 (on file with the author) at 2-4. Although the field visit in Brazil highlighted issues relevant to the engagement of Indigenous Peoples in Brazilian forest governance, this was not one of the key lessons identified by the REDD+ Secretariat in its later summary of the three field trips. See REDD+ Secretariat, "Brief Report of A Study Tour to Brazil on REDD Experience" (on file with the author) at 8 .

684 United Republic of Tanzania, Office of the Vice President, National Framework for Reduced Emissions from Deforestation and Forest Degradation (REDD) (August 2009) (on file with the author).

685 Ibid at 10.

686 Ibid at 10: "The overwhelming need as regards communities and people in the forest is to ensure that they are involved in a positive and mutually beneficial way in management, since this is one of the very few effective means of controlling degradation over very large areas. Already there are some very positive models and success stories in Tanzania with regard to PFM implementation. However, adding carbon (and potentially rewards for carbon reductions) into the PFM will raises a lot of issues that need to be resolved." See also ibid at 11: "The current speed under which PFM projects are established is also observed to be very low. Access to REDD finances could potentially facilitate and speed up this process and possibly reducing the high levels of deforestation and forest degradation."

687 Ibid at 13: "Security of land tenure and resources influences the level of investment on land and conservation of land based natural resources thus, natural resource management depends on land tenure and local community rights." 
strategy. ${ }^{688}$ This initial set of consultations enabled the National REDD+ Taskforce to gauge the challenges involved in discussing REDD+ at the local level, especially since the specific ways in which the eventual implementation of REDD+ in Tanzania might affect the interests of local communities were not necessarily apparent or easy to communicate. ${ }^{689}$ In the synthesis document resulting from the consultations, the National REDD+ Taskforce committed to ensuring "the active participation/involvement of local communities in developing, implementing and monitoring REDD activities," including through additional local consultations and awareness-raising. ${ }^{600}$ The consultations also generated a number of preliminary conclusions that would be reflected in the National REDD+ Taskforce's bifurcated approach to the rights of Indigenous Peoples and local communities. On the one hand, the synthesis acknowledged the critical importance of forests for the livelihoods, sustenance, and cultural practices of rural communities, highlighted the central role the establishment of VLFRs could play in reducing carbon emissions in Tanzania, and singled out forest-dependent communities as an important group whose interests should be considered in a national REDD+ strategy and who should therefore be consulted as part of its development. ${ }^{691}$ On the other hand, the synthesis failed to recognize the status of Indigenous Peoples in Tanzania, concluding that "few communities can rightly be called 'indigenous' people like the Red Indians of the USA, the Aborigines of Australia or the Bambuti pigmies of Congo forests," and that "[t]he only people who could be described as 'indigenous' would be the Hadzabe people of Lake Eyasi who are heavily dependent on forest resources for their livelihoods." ${ }^{692}$

Alongside the consultations that it undertook and the studies that it commissioned to develop a national REDD+ strategy for Tanzania, the National

Institute of Resource Assessment, Preparing for the REDD Initiative in Tanzania: A Synthesised Consultative Report, November 2009 (on file with the author) at 5. A team comprising two rotating members of the National REDD+ Taskforce, supported by the REDD+ Secretariat and two facilitators, met with over 235 government officials, NGO representatives, and villagers in each of Tanzania's eight regional zones. Consultations were most notably held with over 100 village leaders and villagers in one village per regional zone, with a key focus on villages possessing some experience with participatory forest management (Institute of Resource Assessment, Preparing for the REDD Initiative in Tanzania: A Synthesised Consultative Report, Draft - November 2009 (on file with the author) at 7-9 and 37-53).

689 Interview 19 at 2. See also United Republic of Tanzania, Office of the Vice President, Draft National Strategy for the Reduction of Emissions from Deforestation and Forest Degradation $(R E D D+)(D e c e m b e r ~ 2010)$ (on file with the author) at 14.

690 Institute of Resource Assessment, supra note 688 at 21. 691 Ibid at 8, 18-19 and 21.

${ }_{992}$ Ibid at 20 . 
REDD+ Taskforce also prepared an R-PP for submission to the FCPF - a process that brought issues specifically relating to Indigenous Peoples and their rights to the foreground. The draft version of the Tanzanian R-PP submitted to the FCPF in the spring of 2010 highlighted the valuable contributions of participatory forest management in Tanzania and stressed the need to engage local communities in the implementation of REDD+ activities. ${ }^{693}$ This R-PP included no references to the rights or engagement of Indigenous Peoples, however. ${ }^{694}$ This triggered criticisms and suggestions from the FCPF Technical Advisory Panel ${ }^{695}$ as well as the FCPF Participants' Committee. ${ }^{696}$ In response, the National REDD+ Taskforce submitted a revised R-PP in October 2010 that recognized the existence of "concerns" regarding "the rights of indigenous people and communities dependent on forests and the impact of REDD programmes on such groups." ${ }^{697}$ In an annex, the revised R-PP nonetheless specified that: "Tanzania, in principle, does not have Indigenous People but has communities living in and close to forests who's (sic) livelihoods depend greatly on the forests. These are recognized as

693 See generally United Republic of Tanzania, "Forest Carbon Partnership Facility Readiness Preparation Proposal" (15 June 2010), available at: www.forestcarbonpartnership.org/sites/fo restcarbonpartnership.org/files/Documents/PDF/Junzo1o/Tanzania-Revised_R-PP_main_d ocument_V9-10.06.2010.pdf (accessed 9 October 2014).

694 Ibid.

695 Harrison Ochieng Kojwang and TAP Team, "Tanzanian R-PP External Review," available at: www.forestcarbonpartnership.org/sites/forestcarbonpartnership.org/files/Documents/PDF/Ju nzo10/Tanzania_R-PP_TAP_Review_Synthesis.pdf (accessed 9 October 2014) at 4: "One of the TAP members has established that there are National networks of Indigenous Peoples in Tanzania such as the Pastoralists indigenous Non Governmental organization Forum (PINGOS FORUM) and the National Indigenous Peoples Coordinating Committee on REDD (NIPCC-REDD) but they are not mentioned as having been part of the consultation process. Similarly, the National REDD Task Force does not include members from indigenous peoples. On these grounds the TAP recommends the inclusion of representatives of indigenous peoples/forest dependent peoples in the Task Force and under implementation arrangements."

${ }^{696}$ Forest Carbon Partnership Facility (FCPF) Sixth Meeting of the Participants Committee (PC6), 28 June to 1 July, 2010 - Georgetown, Guyana, Informal Summary of Discussions of Tanzania's Draft R-PP, available at: www.forestcarbonpartnership.org/sites/forestcarbonpart nership.org/files/Documents/PDF/Jul2o10/4aSummary_PC6_discussion.pdf (accessed 9 October 2014) at 1: "Participants noted that the R-PP does not identify the Indigenous Peoples as a separate stakeholder group in Tanzania. Participants urged that Tanzania recognize the definition of Indigenous Peoples and clarify how the Indigenous Peoples are being engaged in the REDD+ readiness process in Tanzania."

697 United Republic of Tanzania, "Forest Carbon Partnership Facility Readiness Preparation Proposal" (15 June 2010), available at: www.forestcarbonpartnership.org/sites/forestcarbon partnership.org/files/Documents/PDF/Junzo10/Tanzania-Revised_R-PP_main_document_ V9-10.06.2010.pdf (accessed 9 October 2014) at 16. 
forest dependent and forest adjacent people." ${ }^{8} 8$ This revised version of Tanzania's R-PP attracted another series of criticisms and recommendations from a different set of experts from the FCPF Technical Advisory Panel as well as reviewers within the FCPF Secretariat, who all stressed the need for additional consultations with stakeholders and a greater focus on land and tenure rights in the development of Tanzania's R-PP. ${ }^{699}$ Regarding the recognition of the concept of Indigenous Peoples, the FCPF Secretariat explained that this would henceforth be discussed "at the broader portfolio level between the Government of Tanzania and the World Bank" and was, in effect, no longer identified as a critical issue in the development of Tanzania's R-PP. ${ }^{700}$

A coalition of conservation and development NGOs implementing REDD+ pilot projects in Tanzania submitted similar recommendations for the finalization of Tanzania's R-PP to the FCPF and the National REDD+ Taskforce. These recommendations did not refer to Indigenous Peoples, but focused instead on the enhancement of community rights through Tanzania's REDD activities, the definition and scope of village rights to govern forests on general lands, and the need for greater civil society participation in Tanzania's REDD+ readiness activities, most notably through representation on the National REDD+ Taskforce. $^{701}$ Pursuant to these various suggestions, the FCPF Participants' Committee requested, in November 2010, that Tanzania implement additional changes to its R-PP that included "giving due consideration to the representation of and engagement with civil society, forest

Ibid, Annexes to United Republic of Tanzania, "Forest Carbon Partnership Facility Readiness Preparation Proposal" (15 June 2010), available at: www.forestcarbonpartnership .org/sites/forestcarbonpartnership.org/files/Documents/PDF/Sepzo1o/Tanzania_R-PP_Ann exes\%20_August_2010.pdf (accessed 16 October 2014) at 24. The R-PP thus envisaged conducting a study to "specifically identify forest dependent communities, legal institutions and organisations representing them, challenges and opportunities for REDD, mechanisms for effective participation in the REDD readiness and implementation processes and how identified challenges could be addressed to maximize benefits of REDD to such communities."

699 Australia, Argentina, and Denmark, “Tanzanian R-PP External Review," available at: www.forestcarbonpartnership.org/sites/forestcarbonpartnership.org/files/Documents/PDF/ Oct2o10/FCPF\% 20Assessment\%zoof\%zoTanzania's\%zoR-PP\% 20Consolidated\%zoAUS-AR G-DK\% zofinal.pdf (accessed 16 October 2014) at 4-7; FCPF FMT, "Comments from the World Bank Team on Tanzania's R-PP" (version submitted in October 2010), available at: www.forestcarbonpartnership.org/sites/forestcarbonpartnership.org/files/Documents/PDF/ Oct2o10/World\%2oBank\%2oComments\%20on\%2oTZ\%zoR-PP.pdf at 2-4.

700 Ibid at 3.

701 Tanzania Forest Conservation Group et al., "Recommendations from Tanzanian Civil Society with regard to Tanzania's Readiness Preparation Proposal to the Forest Carbon Partnership Facility," available at: www.forestcarbonpartnership.org/sites/forestcarbonpart nership.org/files/Documents/PDF/Octzo10/PC\%203c\%zoTanzania\%zoR-PP\%zoCSO\%zoR ecommendations.pdf (accessed 16 October 2014). 
dependent people, and associations of Wildlife Management Areas in the national and subnational policy and decision making bodies on REDD+, including the national Task Force" and "further clarify[ing] and elaborat[ing] on land tenure and related rights, and how these will be incorporated into benefit-sharing systems." $7^{\circ 2}$ As such, despite the fact that the World Bank's Operational Policy on Indigenous Peoples would be applicable to the delivery of any funding Tanzania might receive from the FCPF for its REDD+ readiness activities, Tanzania's refusal to acknowledge the status and rights of Indigenous Peoples did not stand in the way of the approval of its R-PP by the FCPF Participants' Committee at a later meeting. ${ }^{703}$

In December 2010, the National REDD+ Taskforce released a first draft of Tanzania's National REDD+ Strategy, ${ }^{704}$ which reproduced much of the language that had been adopted in the synthesis document on the consultations held in the fall of 2009 and the R-PP Tanzania submitted to the FCPF in October 2010. ${ }^{705}$ As such, the draft strategy focused on lessons learned from Tanzania's experience with community-based forest management and the way in which the country could contribute to, and benefit from, from the pursuit of REDD+ activities. ${ }^{706}$ It envisaged several strategic interventions for REDD+ that would reduce poverty and support livelihoods among rural communities, ${ }^{707}$ strengthen forest governance, ${ }^{708}$ and enhance participatory land-use planning and conflict resolution. ${ }^{709}$ As far as Indigenous Peoples were concerned, the draft strategy cited the safeguards recently adopted within the UNFCCC in Cancun, including those relating to the knowledge and rights of Indigenous Peoples and local communities and their full and effective participation in REDD+ activities. ${ }^{710}$ It also highlighted that Tanzania had signed the UN Declaration on the Rights of Indigenous Peoples, ${ }^{711}$ and included the World Bank's definition of Indigenous Peoples in its glossary. ${ }^{712}$ On the other hand, the draft strategy averred that "the issue of engagement of

702 FCPF PC, "Resolution PC/7/2010/1: Tanzania's Readiness Preparation Proposal," available at: www.forestcarbonpartnership.org/sites/forestcarbonpartnership.org/files/Documents/ PDF/Nov2010/PC7\%20Resolutions.pdf (accessed 16 October 2014) at 2.

703 Tanzania submitted another R-PP in line with the comments made by the Participants' Committee, but opted not to apply for funding from the FCPF readiness mechanism (FCPF, "REDD Readiness Progress Fact Sheet. Country: Tanzania. March 2014," available at: www .forestcarbonpartnership.org/sites/forestcarbonpartnership.org/files/Documents/PDF/ Marzo12/REDD\%2oTanzania\%20Fact\%2oSheet_March\%202012_o.pdf (accessed 22 October 2014) at 1). On the other hand, it is quite possible that the recognition of the rights of Indigenous Peoples may be raised again if Tanzania decides to apply for funding from the FCPF Carbon Fund (Nordeco \& Acacia, supra note 675 at 13-14).

704 Tanzanian Draft National Strategy for REDD+, supra note 689. $705 \quad$ Ibid at 10-11.

706 Ibid at 36. $707 \quad$ Ibid at 83. $708 \quad$ Ibid at 84. ${ }^{709} \quad$ Ibid at $87.7^{70} \quad$ Ibid at 11.

711 Ibid. $\quad 7^{12}$ Ibid at 100. 
'indigenous peoples' in Tanzania is being handled via the concept 'forestbased communities' rather than 'indigenous peoples' - a concept which some stakeholders found derogatory and discriminatory." ${ }^{713}$ In this regard, the draft strategy further identified "the Hadzabe people of Lake Eyasi who are heavily dependent on forest resources for their livelihoods" and "groups like pastoralists and other communities living adjacent to forest reserves" as forest-based communities and stressed the importance of considering their interests and building on their knowledge and practices in the design and implementation of REDD+ in Tanzania. ${ }^{714}$

During the first quarter of 2011, the National REDD+ Taskforce organized a series of multi-stakeholder workshops to discuss the draft National REDD+ Strategy in seven zones across Tanzania ${ }^{715}$ and solicited feedback from key international and domestic interlocutors. Through written comments and ongoing dialogue, the Norwegian Embassy pressed the National REDD+ Taskforce to recognize the distinctive status and rights of Indigenous Peoples as separate from forest-dependent communities..$^{76}$ For its part, the UN-REDD Programme did not raise the issue of Indigenous rights and instead highlighted the importance of holding additional stakeholder consultations as well as broadening the membership of the National REDD+ Taskforce to include civil society representatives. ${ }^{717}$ Finally, the conservation and development NGOs implementing REDD+ pilot projects in Tanzania released a series of briefs and statements that reiterated many of their previous recommendations regarding strengthening participatory forest management, including civil society in decision-making, recognizing community rights to unreserved forests, and creating opportunities for communities to receive direct payments from REDD+ activities. They also included a new recommendation (stemming from the recent adoption of the Cancun Agreements) that the national strategy contain a set of social and environmental safeguards. ${ }^{718}$

713 Ibid at $11 . \quad 714$ Ibid at 11.

715 REDD+ Secretariat, “Tanzania REDD Initiative Newsletter” Issue 5, March 2011 (on file with the author) at 4 .

716 Interview 16 at 3; Interview 52 at 6; Interview 65 at 4. Norwegian Embassy, "Consolidated Comments to the draft National REDD+ Strategy for Tanzania” (21 February 2011) (on file with the author) at 5 (noting that a section on "forest dependent communities deserves more reference to United Nations and African Union documentation relating to Indigenous Peoples.")

717 Correspondence from Ralf Ernst, UN-REDD Coordinator - Tanzania to Secretariat of the National REDD+ Task Force (on file with author) at 2-5.

718 See MJUMITA \& Tanzania Forest Conservation Group, "A one-step guide to making the National REDD strategy more pro-poor” Policy Brief, 2011 (on file with the author); Tanzania Forest Conservation Group, "Feedback on the Tanzania National REDD Strategy, prepared 
In early 2012, the National REDD+ Taskforce responded to some of these comments by naming a civil society representative to the taskforce ${ }^{719}$ and creating a technical working group to focus on legal, governance, and safeguards issues. ${ }^{720}$ In what has been described as a "milestone achievement" for the recognition of the status of Indigenous Peoples in the Tanzanian policymaking process, ${ }^{721}$ this working group included a representative from "Pastoralists and Hunter Gatherer Organizations." ${ }^{22}$ Although these two nominations provided new opportunities for civil society advocates to influence the development of the national REDD+ strategy, the work of the National REDD+ Taskforce continued to be largely dominated by government representatives and their views on the future of REDD+ in Tanzania. ${ }^{723}$ This is clearly reflected in the text of the draft National REDD+ Strategy released in June 2012. ${ }^{724}$ While it acknowledged the role that the allocation of land and tenure rights for local communities and the establishment of VLFRs could play in the pursuit of REDD+ in Tanzania, ${ }^{725}$ this second draft strategy did not recognize the customary rights of villages to manage their forests on unreserved lands ${ }^{726}$ and continued to privilege a national funding mechanism for receiving international payments for REDD+ and channeling related benefits to local communities. ${ }^{727}$ With respect to Indigenous Peoples, the strategy omitted all references previously included in the first draft to Indigenous Peoples, pastoralists, hunter-gatherers, or the UN Declaration on the Rights of Indigenous Peoples. ${ }^{28}$ That said, this second draft strategy

by the REDD Pilot Projects" (2011) (on file with the author); MJUMITA and Tanzania Forest Conservation Group, "Five Steps to Get REDD Right(s)" (2011) (on file with the author); Jessica Campese, "Integrating REDD+ Social and Environmental Safeguards and Standards in Tanzania" TFCG Technical Report 32, July 2011 (on file with author).

719 Nordeco \& Acacia, supra note 674 at 8. The civil society representative was Charles Meschack, the Executive Director of the Tanzania Forest Conservation Group (TFCG), one of the NGOs implementing a pilot project in Tanzania, and a specialist in community forest governance in Tanzania (Interview 14 at $6-7$ ).

720 Ibid at $11 . \quad{ }^{21} \quad$ IFAD, supra note 646 at 34 .

722 Interview 5 at $12-13$. The representative of Pastoralists and Hunter Gatherers was Elifuraha Isaya Laltaika, the Executive Director of the Association for Law and Advocacy for Pastoralists (ALPA). A trained lawyer and law professor, Laltaika also served as the Indigenous representative for Africa on the Policy Board of the UN-REDD Programme at a global level. See ALPA, "Achievements," available at: http://alapa.or.tz/alapa/?page_id=8 (accessed 20 October 2014).

723 Nordeco \& Acacia, supra note 675 at 9.

724 United Republic of Tanzania, Office of the Vice President, National Strategy for Reducing Emissions from Deforestation and Forest Degradation, Second Draft (June 2012) (on file with the author).

725 Ibid at 10, 12, 22, 35, and 43. ${ }^{726}$ Ibid at 22. ${ }^{227}$ Ibid at 37.

728 Oddly enough, the glossary to this second draft strategy still included the definition of Indigenous Peoples, a term that did not appear in the text of the strategy itself (ibid at 58). 
included new commitments to adopting a set of social and environmental safeguards for REDD $+{ }^{729}$ and undertaking a strategic and social impact assessment that would "give special consideration to livelihoods [and] resource use rights (including those of forest dependent Peoples)." $73^{\circ}$ The release of the second draft strategy prompted a number of international and domestic stakeholders to reiterate their concerns and recommendations regarding the need to further recognize and engage with Indigenous Peoples, ${ }^{731}$ explicitly recognize and clarify the land and tenure rights of villages in relation to unreserved forests and the carbon stored in village forests, ${ }^{72}$ consider adopting a nested approach for the management of international REDD+ payments and the sharing of benefits derived therefrom, ${ }^{733}$ and systematically integrate social and environmental safeguards into the very body of the strategy. ${ }^{734}$

During the summer and fall of 2012, the National REDD+ Taskforce undertook a final series of consultations across Tanzania, held a series of dialogues with stakeholders involved with REDD+ pilot projects, and organized workshops with parliamentarians in the Zanzibar House of Representatives and the Parliament of Tanzania. ${ }^{735}$ After one final rewrite by the National REDD+ Taskforce, the National REDD+ Strategy was formally approved by the National Climate Change Steering Committee and launched in March $2013 .{ }^{736}$ Like previous drafts, the final draft of Tanzania's National REDD+ Strategy adopts an approach that supports the engagement and rights of local communities in the development and implementation of REDD+ activities while simultaneously excluding Indigenous Peoples and their rights from its purview. As far as participatory rights are concerned, Tanzania's National REDD+ Strategy includes as one of its main objectives and result areas the engagement and active participation of multiple stakeholders in the design and implementation of REDD+ schemes. ${ }^{737} \mathrm{To}$ this end, the National REDD+ Strategy envisages numerous strategic actions, including building the capacity of local communities in relation to REDD $+{ }^{73^{8}}$, engaging domestic civil society organizations, and learning from their experiences with pilot projects. ${ }^{739}$ On the other hand, Tanzania's National REDD+ Strategy does not recognize the importance of the right to

729 Ibid at 35. $\quad{ }^{70}$ Ibid at 48. ${ }^{731}$ Interview 5 at 8-9; Interview 16 at 3; Interview 52 at 6.

$73^{2}$ TFCG et al., "Recommendations from Civil Society Organisations for Tanzania's znd Draft National REDD+ Strategy and Draft Action Plan” (on file with the author) at 2.

733 Ibid at 5. 734 Ibid at 3. See also Interview 23 at 5.

735 TFCG, “TZ-REDD Newsletter" Issue 9, January 2013 (on file with the author) at 3.

${ }_{736}$ National REDD+ Secretariat, "REDD+ Strategy Development and Implementation Process in Tanzania (1 October 2012 to 31 March 2013)" (on file with the author).

737 Tanzanian National Strategy for REDD+, supra note 615 at 3 and $42 . \quad 73^{8} \quad$ Ibid at 42.

739 Ibid at 43. 
FPIC, nor does it acknowledge the role that traditional knowledge might play in the design and implementation of REDD+ activities. ${ }^{70}$

Tanzania's National REDD+ Strategy is much more comprehensive in its approach to the substantive rights of local and forest-dependent communities and recognizes that an effective REDD+ mechanism will build on as well as contribute to the promotion of rights and livelihoods. ${ }^{71}$ The National REDD+ Strategy most notably identifies the following as key strategic actions for reducing carbon emissions from forest-based sources: improving access to energy alternatives and economic opportunities for forest-dependent communities, ${ }^{7{ }^{2}}$ scaling up community-based forest management, ${ }^{743}$ accelerating participatory land-use planning (leading to land reforms and the issuance of customary rights of occupancy), ${ }^{744}$ and supporting the demarcation and mapping of village lands. ${ }^{745}$ At the same time, despite its emphasis on participatory forest management and poverty alleviation, the National REDD+ Strategy maintains a preference for the creation of a national fund to receive and manage REDD+ finance. ${ }^{746}$ This went against the demands of conservation and development NGOs, who had advocated for a nested mechanism ${ }^{747}$ and were generally concerned about the ability of a central government-run mechanism to deliver benefits to local communities. ${ }^{74^{8}}$ As such, the establishment of an equitable and transparent mechanism for REDD+ finance and benefit-sharing remains one of the key outstanding issues that Tanzania must resolve in order to be ready for the full operationalization of REDD+ at the national level. ${ }^{749}$

Another key element of jurisdictional REDD+ readiness that was not finalized in Tanzania's National REDD+ Strategy relates to the adoption of social and environmental safeguards for REDD+. ${ }^{750}$ Tanzania's National REDD+ Strategy includes a commitment to develop and enforce social and environmental safeguards to ensure that REDD+ activities deliver multiple benefits, including in terms of "forest dependent communities' rights," and to limit its potential adverse impacts on "the livelihoods and rights of

740 The only reference to traditional knowledge in the National REDD+ Strategy is found in a section that calls for the "application of useful traditional knowledge" to address forest fires as a driver of deforestation (ibid at 49).

741 See, e.g., ibid at xxii, 9-13, 15, 26-27, 34, 48-49, 52-54, and 63. $7_{42}$ Ibid at 48 .

743 Ibid. 744 Ibid at 48-49. 745 Ibid at 51. ${ }^{746}$ Ibid at 26-27.

747 TFCG et al., supra note 732 at 5 .

$74^{8}$ Interview 14 at $7-8$; Interview 29 at $7-8$; Interview 30 at 2.

749 Nordeco \& Acacia, supra note 674 at 15-16; Nelson Gapare \& Christopher William, "Final Evaluation of the UN-REDD Tanzania National Programme” (4 December 2013), available at: www.fao.org/fileadmin/user_upload/oed/docs/UNJPURT238UNJ_2013_ER.pdf (accessed 7 January 2014) at 56.

750 The development of Tanzania's safeguards policy is discussed in Section 4.3.2. 
communities." ${ }^{51}$ To this end, the strategy plans for the establishment of a national safeguards information system in accordance with the requirement set by the Cancun Agreements, as well as the operationalization of safeguards based on Tanzania's existing laws and policies and drawing on the standards adopted by the UNFCCC, the UN-REDD Programme, the World Bank, and the REDD+ SES..$^{72}$ In this second regard, Tanzania's National REDD+ Strategy emphasizes that an eventual set of social and environmental safeguards "will give special consideration to livelihoods, resource use rights (including those of forest dependent Peoples), conservation of biodiversity, cultural heritage, gender needs, capacity building and good governance." 753

In comparison with the first draft of the National REDD+ Strategy released in December 2010, the final draft includes fewer references to and less consideration of the rights and status of Indigenous Peoples in Tanzania. Unlike previous drafts and other policy documents, the final draft does not even explain whether the concept of Indigenous Peoples is applicable in Tanzania, nor does it identify forest-dependent communities or discuss their distinctive character and needs. What is more, Tanzania's National REDD+ Strategy proposes a number of interventions that could have negative impacts on Indigenous Peoples in Tanzania, most notably in its identification of pastoralism as a driver of deforestation and forest degradation and its commitment to reviewing "livestock policy and strategies to reduce overgrazing and nomadic pastoral practices" and supporting "commercial livestock destocking campaigns." 754 Given the economic and political marginalization of pastoralists in Tanzania and the barriers that stand in the way of recognition of their customary land rights, the implementation of these types of REDD+ activities could cause significant harm to Indigenous pastoralist communities like the Maasai and the Barabaig. ${ }^{755}$

All told, the National REDD+ Strategy presents meaningful opportunities for jurisdictional REDD+ activities to support the implementation of the rights of forest-dependent communities to govern their forests in line with the existing mechanisms laid out in the Forest Act. That said, the extent to which arrangements for REDD+ finance and benefit-sharing may enable communities to actually benefit from the funds generated by REDD+ remains an open question. Whatever challenges local communities may face in accessing the benefits engendered by REDD+, they still fare much better than

$75^{1}$ Tanzanian National Strategy for REDD+, supra note 615 at $52 . \quad 75^{2}$ Ibid at $52-54$.

753 Ibid at 54. 754 Ibid at 50.

755 Interview 5 at 8-11 and 13-14. See also Nordeco \& Acacia, supra note 675 at 25. 
Indigenous Peoples. Indeed, the National REDD+ Strategy completely ignores the status and rights of Indigenous Peoples and even creates important risks for the continuation of the traditional livestock practices of pastoralists.

\subsubsection{Rights in the Social and Environmental Safeguards for REDD+}

The development of safeguards for REDD+ in Tanzania was first identified as an item to be addressed in the National REDD Framework adopted by the National REDD+ Taskforce in August 2009. ${ }^{756}$ The National REDD+ Taskforce subsequently invited a team from the REDD+ SES Initiative to hold a series of meetings and workshops with multiple stakeholders in September 2009 to discuss the development of social and environmental safeguards in Tanzania. ${ }^{757}$ This visit provided an opportunity for Tanzanian officials and nongovernmental representatives to learn about the concept and importance of safeguards ${ }^{75^{8}}$ and revealed differences of opinion between the team from the REDD+ SES Initiative and the Tanzanian participants regarding the definition and application of concepts such as Indigenous Peoples, forestdependent communities, and customary rights in Tanzania. 759

Despite this initial swell of interest and the fact that two Tanzanians, one from government and the other from civil society, joined the international steering committee of the REDD+ SES Initiative, ${ }^{760}$ the development of social and environmental safeguards remained dormant in Tanzania for two years due to the National REDD+ Taskforce's reluctance to apply external standards in sensitive areas of law and policy. ${ }^{761}$ However, the emergence of safeguards information systems as an element of jurisdictional REDD+ readiness within the UNFCCC in 2010 and the combined pressures from international and domestic interlocutors for Tanzania to adopt its own set of social and environmental safeguards eventually led the National REDD+ Taskforce to create a technical working group on legal, governance, and safeguards issues and recruit a consultant to facilitate the process of applying and interpreting

756 National REDD Framework, supra note 684 at 21.

757 REDD+ SES, "REDD+ Social and Environmental Standards Consultation Meetings, gth11th Sept 2009, Tanzania” (9 October 2009) (on file with the author).

$75^{8}$ Interview 23 at $8-9$.

759 Interview 84 at 9-10. See also REDD+ SES, “Appendix 2. Draft Indicators for REDD+ Social \& Environmental Standards. Version July 9th 2009 with new indicators and comments proposed by working groups in Tanzania on Sept 9th 2009" in REDD+ SES, supra note 757 at $1-4$.

$760 \quad$ Interview 77 at $13 . \quad 7^{61}$ Interview 84 at 8. 
the REDD+ SES in early 2012. ${ }^{762}$ Throughout 2012 and the first half of 2013, the National REDD+ Taskforce and the National REDD+ Secretariat completed the first steps set out in the guidelines for the use of the REDD+ SES, including the organization of awareness raising and capacity-building activities, the selection of a facilitation team, and the creation of a multi-stakeholder standards committee. ${ }^{763} \mathrm{~A}$ first draft of the social and environmental safeguards for REDD + was prepared by the consultant and finalized through a series of workshops held with government officials and representatives of the pilot projects. ${ }^{764}$ This draft was released in June $2013^{765}$ and was discussed through a series of consultations held with multiple stakeholders across Tanzania during the summer of $2013 .{ }^{766} \mathrm{~A}$ final draft policy on social and environmental safeguards for REDD + was then approved by the National Climate Change Steering Committee and adopted by the Vice President's Office in October 2013. ${ }^{767}$

Tanzania's REDD+ social and environmental safeguards policy explains that these safeguards are meant to provide a "country-specific tool" to operationalize the REDD+ safeguards listed in the Cancun Agreements ${ }^{768}$ and ensure "that implementation of REDD+ activities respect the rights of all relevant stakeholders including forest dependent communities, avoid social and environmental harm and generate significant benefits for the present and future generations." ${ }^{69} 9$ The safeguards are comprised of eight principles, fortyeight criteria, and 107 indicators, and the safeguards policy provides a thorough overview of how each of these principles relate to existing laws and institutions in Tanzania as well as the safeguards included in the Cancun Agreements. Although the safeguards policy claims they were drafted on the basis of a wide range of international and foreign sources, Table 4.1

762 Interview 16 at 7; Interview 23 at 2 and 8-9; Interview 84 at 8; Nordeco \& Acacia, supra note 675 at 24 . See also the discussion above regarding the emergence of safeguards as an issue in the development of the national REDD+ strategy in Tanzania.

763 United Republic of Tanzania Vice-President's Office, Tanzania REDD+ Social and Environmental Standards. Final Draft (October 2013) (on file with the author) at 11-12.

764 Ibid at 12 .

765 United Republic of Tanzania Vice-President's Office, Tanzania REDD+ Social and Environmental Standards (June 2013) (on file with the author).

766 Tanzania REDD+ Social and Environmental Standards. Final Draft, supra note 763 at 12.

${ }_{767} \mathrm{Ibid}$. At this stage, the Vice-President's Office is intending to secure additional funding from the Norwegian Embassy to complete the final four steps set out in the guidelines set by the REDD+ SES Initiative, namely the preparation of a monitoring and assessment plan, the collection and assessment of monitoring information, the organization of a stakeholder review of this assessment report, and the publication of a report assessing the national safeguards policy against the REDD+ SES indicators (Email Communication no 4 at 1; Nordeco \& Acacia, supra note 675 at 13-14).

768 Tanzania REDD+ Social and Environmental Standards. Final Draft, supra note 763 at 11.

769 Ibid at 9. 
TABLE 4.1. Comparison of the REDD+SES and Tanzania's draft social and environmental safeguards

Tanzania's social and environmental safeguards

REDD+ SES

"Principle 1: The REDD+ initiative contributes to good governance and sustainable natural forest resources."

"Principle 2: The REDD+ initiatives recognize, guarantee and respect forest dependent communities and marginalized groups' rights to land and natural forest resources."

"Principle 3: The REDD+ initiatives improve livelihoods and well-being of forest dependent communities especially the marginalized and vulnerable groups."

"Principle 4: Key stakeholders participate fully and effectively in designing, planning, implementing, monitoring and evaluating REDD+ initiatives and MRV process."

"Principle 5: All key stakeholders particularly the forest dependent communities and marginalized groups have timely access to appropriate and accurate information about REDD+ initiative including MRV data to enable them make informed decision."

"Principle 6: The costs incurred and benefits generated by the REDD+ initiative are shared in a timely, transparent and equitable manner among all relevant stakeholders."

"Principle 7: REDD+ initiative maintains, promotes and enhances sustainable conservation of the country's natural forests for their biodiversity and all ecosystem services (co-benefits) while meeting the needs of forest dependent communities."

"Principle 4: The REDD+ program contributes to good governance, to broader sustainable development and to social justice."

"Principle 1: The REDD+ program recognizes and respects rights to lands, territories and resources."

"Principle 3: The REDD+ program improves long-term livelihood security and well-being of Indigenous Peoples and local communities with special attention to women and the most marginalized and/or vulnerable."

"Principle 6: All relevant rights holders and stakeholders participate fully and effectively in the REDD+ program."

"Criteria 6.5 The REDD+ program ensures that rights holders and stakeholders have the information that they need about the REDD+ program, provided in a culturally appropriate, gender sensitive and timely way, and the capacity to participate fully and effectively in program design, implementation and evaluation."

"Principle 2: The benefits of the REDD+ program are shared equitably among all relevant rights holders and stakeholders."

"Principle 5: The REDD+ program maintains and enhances biodiversity and ecosystem services." 
TABLE 4.1. (continued)

\begin{tabular}{ll}
$\begin{array}{l}\text { Tanzania's social and environmental } \\
\text { safeguards }\end{array}$ & REDD+ SES \\
\hline $\begin{array}{l}\text { "Principle 8: REDD+ initiatives recognize, } \\
\text { respect and utilize existing complaint and } \\
\text { dispute resolution mechanism at both local }\end{array}$ & $\begin{array}{l}\text { identifies and uses processes for } \\
\text { effective resolution of grievances } \\
\text { and national levels for REDD+ related } \\
\text { claims." }\end{array}$ \\
$\begin{array}{ll}\text { and disputes relating to the design, } \\
\text { implementation and evaluation of } \\
\text { the REDD+ program, including } \\
\text { disputes over rights to lands, } \\
\text { territories and resources relating to } \\
\text { the program." }\end{array}$ \\
\hline
\end{tabular}

demonstrates that the structure and content of the safeguards were primarily developed through an adaptation of the REDD+ SES to the context of Tanzanian law and policy.

Through their sustained and detailed emphasis on good forest governance, land and resource rights, support for livelihoods, full and effective participation, equitable sharing of benefits, and dispute resolution mechanisms, Tanzania's social and environmental safeguards are strongly supportive of the participatory and substantive rights of forest-dependent communities. On the other hand, Tanzania's social and environmental safeguards fail to recognize or protect the status and rights of Indigenous Peoples. Although the safeguards policy includes a few brief allusions to Indigenous Peoples in its discussion of international guidance on REDD+ safeguards, ${ }^{770}$ the actual principles, criteria, and indicators that form the heart of the safeguards themselves do not include any references to Indigenous Peoples or their rights. The only clear consideration of the concept of Indigenous Peoples is in the policy's glossary, where it is subsumed within a broader definition of forest-dependent communities. ${ }^{771}$ In fact, all of the references to Indigenous Peoples and local communities included in the REDD+ SES have been replaced by the

Ibid at 9 and 35 .

${ }^{771}$ Ibid at 32: "These are people who live inside forests as hunter-gatherers or shifting cultivators, and who are heavily dependent on forests for their livelihoods primarily on a subsistence basis. People in this category are often indigenous people or people from minority ethnic groups who; a) Self identify themselves as members of a distinct indigenous cultural group and recognition of this identity by others; b) Have collective attachment to geographically distinct habitats or ancestral territories in the project area and to the natural resources in these habitats and territories; c) Have customary cultural, economic, social, or political institutions that are separate from those of the dominant society or culture; and d) Have an indigenous 
term "forest-dependent communities and marginalized groups" in Tanzania's social and environmental safeguards. For instance, whereas criterion 1.3 of the REDD+ SES provides that " $t$ the REDD+ program requires the free, prior and informed consent of Indigenous Peoples and local communities for any activities affecting their rights to lands, territories and resources," criterion 2.2 of Tanzania's social and environmental safeguards mandates that "[t]he REDD+ initiative promotes and respects the right to free prior and informed consent (FPIC) of forest dependent communities and marginalized groups for any REDD+ activities that might affect their rights to land and natural resources." This application of the right to free, prior, and informed consent to forestdependent communities is striking for two reasons. For one, it represents a complete transformation of this right, which first emerged in relation to Indigenous Peoples under international human rights law, ${ }^{772}$ was then extended to local communities within the REDD+ SES, ${ }^{773}$ and now applies to forestdependent communities only in the Tanzanian context. For another, it recognizes and aims to protect a right that forest-dependent communities do not hold, under Tanzanian law, outside of the structure of the village unit of governance under the Village Land Act and Forest Act. ${ }^{774}$ Accordingly, the development and adoption of Tanzania's social and environmental safeguards led to the expansion of the rights held by local communities, while simultaneously neglecting those of Indigenous Peoples.

\subsection{EXPLAINING THE CONVEYANCE AND CONSTRUCTION OF RIGHTS THROUGH JURISDICTIONAL REDD+ ACTIVITIES IN TANZANIA}

The development of a National REDD+ Strategy and a safeguards policy in Tanzania reflect two very different outcomes with respect to the conveyance and construction of the rights of Indigenous Peoples and local communities. In essence, the National REDD+ Strategy reflects the nonconveyance of exogenous legal norms relating to the rights of Indigenous Peoples and local communities. Indeed, in spite of the efforts of multiple international actors

language, often different from the official language of the country or the region. 2. People who live near forests, usually involved in agriculture outside the forest, who regularly use forest products (timber, fuel wood, bush foods, medicinal plants etc.) partly for their own subsistence purposes and partly for income generation (FAO)."

772 Gilbert \& Doyle, supra note 60.

773 REDD+ SES, "REDD+ Social \& Environmental Standards" Version 2, supra note 409 at 9.

774 Interview 20 at 9; Interview 24 at 5 . This is also clear from the comparison of this right with existing Tanzanian law and policy (Tanzania REDD+ Social and Environmental Standards, supra note 768 at 29). 
(Norway, the FCPF, and the UN-REDD Programme) and the advocacy of Indigenous activists, the National REDD+ Taskforce never adopted the exogenous legal norms relating to the rights of Indigenous Peoples in the context of its National REDD+ Strategy. I would argue that this can be best explained by the enduring resilience of a powerful counter-norm to the effect that all Tanzanians are Indigenous and that the concept of Indigenous Peoples is a concept that applies to pre-colonial communities in the Americas, but not Africa. ${ }^{775}$ This counter-norm appears to have prevented the internalization of any exogenous norms relating to the concept and rights of Indigenous Peoples in the context of the National REDD+ Strategy. ${ }^{776}$ In addition, this outcome may also stem from the inability of Indigenous Peoples in Tanzania to effectively mobilize for the recognition of their status and rights. In this regard, it bears mentioning that the Indigenous movement in Tanzania is disjointed and fragmented and has not managed to build effective alliances with other domestic or international actors both in general and in the specific context of Tanzania's jurisdictional REDD+ readiness process.

While Tanzania's National REDD+ Strategy does recognize the importance and role of the forest, land tenure, and resource rights of local communities in the design and development of REDD+ activities, I would argue that this can be primarily explained by the existing endogenous legal norms in Tanzania. Throughout the development of the National REDD+ Strategy, the National REDD+ Taskforce identified the implementation of the CBFM and JFM provisions under the Forest Act as central to the pursuit of jurisdictional REDD+ activities in Tanzania. ${ }^{777}$ This commitment to communitybased approaches to forest governance stemmed first and foremost from a belief on the part of the National REDD+ Taskforce that community forestry constituted an effective and efficient way of addressing important local drivers of deforestation and generating reductions in carbon emissions in forests. For the most part, this belief was itself embedded in pre-existing shared understandings about the legitimacy of village governance and the superiority of

Interview 21 at 2 ("There are no Indigenous Peoples in Tanzania because all Tanzanians are indigenous. Living in a rural area does not make someone any less Tanzanian or any more Indigenous. In fact, only South America has truly Indigenous Peoples.")

${ }_{776}$ In the case of the safeguards policy, this counter-norm can be seen as having led to the construction of a hybrid legal norm providing Indigenous rights to forest-dependent communities, but not Indigenous Peoples.

777 See National REDD Framework, supra note 684 at 11-14 and 23-24; Preparing for the REDD Initiative in Tanzania, supra note 688 at 8, 18-19 and 21; Tanzanian Draft National Strategy for REDD+, supra note 689 at 36 and 87; Tanzanian 2nd Draft National Strategy for REDD+, supra note 724 at 10, 12, 22, 35, and 43; Tanzanian National Strategy for REDD+, supra note 615 at $4^{8-51 .}$ 
wparticipatory forest management that had developed in Tanzania throughout the 1990s and were formally enshrined in the Village Land Act and Forest Act. Accordingly, the creation of a strategy for jurisdictional REDD+ can itself be seen as an exogenous legal norm that was translated by the National REDD+ Taskforce on the basis of the endogenous legal norms that defined the appropriateness of community-based mechanisms in Tanzanian forest governance. ${ }^{77^{8}}$

On the other hand, the National REDD+ Taskforce never altered its position about the necessity of creating a national trust fund to receive, manage, and channel payments for REDD+, ${ }^{779}$ despite the preference for a nested REDD+ finance mechanism that was clearly, constantly, and unanimously expressed by the proponents of all nine REDD+ pilot projects ${ }^{70}$ as well as the civil society representatives serving on the National REDD+ Taskforce and its technical working groups. ${ }^{781}$ In all likelihood, the National REDD+ Taskforce's steadfast refusal to consider a nested approach to REDD+ finance was motivated by a strong inclination to retain control and influence over the management and distribution of funding for REDD+. ${ }^{82}$ Indeed, while the pursuit of jurisdictional REDD+ activities may have been seen as an opportunity for Tanzanian government officials to implement existing mechanisms relating to participatory forest management, it was also perceived as an opportunity to increase funding for the Forest and Beekeeping Department. ${ }^{783}$ The material interests of Tanzanian government officials thus explain the incongruous manner in which the National REDD+ Strategy recognizes local communities as best placed to manage forests under REDD+, while at the same time denying them the capacity to access or manage the funds that might be generated by REDD+ activities. ${ }^{784}$ All told, the

$77^{8}$ Interview 19 at 1.

779 See National REDD Framework, supra note 684 at 9-10; Tanzanian Draft National Strategy for REDD+, supra note 689 at 74; Tanzanian 2nd Draft National Strategy for REDD+, supra note 724 at 37; Tanzanian National Strategy for REDD+, supra note 615 at 26-27.

780 TFCG, "Feedback on the Tanzania National REDD Strategy, prepared by the REDD Pilot Projects" supra note 718 at 3; MJUMITA \& TFCG, "Five Steps to Get REDD Right(s)" supra note 718 at 2; TFCG et al., "Recommendations from Civil Society Organisations for Tanzania's 2nd Draft National REDD+ Strategy and Draft Action Plan" supra note 732 at 5.

$7^{81} \quad$ Interview 14 at 7.

${ }^{782}$ Interview 14 at 8; Interview 16 at 7 ; Interview 19 at 3 ; Interview 20 at 5; Interview 21 at 2. At a deeper level, the reasoning in favor of a central fund was moreover embedded in an enduring ideological resistance to market-based approaches that prevails among many government officials in Tanzania (Interview 15 at 12).

783 Interview 15 at 2 and $7-8$; Interview 19 at 1.

784 Indeed, if the focus on participatory forest management had been primarily motivated by reasons of principle, having to do with the dignity, autonomy, or ability of local communities, one would expect that this would also translate into greater respect for the right of local communities to manage, and benefit from, the funds generated through REDD+. 
elaboration of a National REDD+ Strategy reflects the influence of endogenous, rather than exogenous, legal norms, especially as far as the rights of Indigenous Peoples and local communities are concerned.

Unlike the National REDD+ Strategy, Tanzania's policy on social and environmental safeguards reflects the conveyance and construction of the rights of Indigenous Peoples and local communities. I would argue that this process can be explained by a causal sequence involving multiple causal mechanisms. To begin with, the National REDD+ Taskforce's commitment to developing a policy on social and environmental safeguards for REDD+ was driven by the combined effect of the mechanisms of cost-benefit adoption and mobilization. Once the development of an information system for reporting on social and environmental safeguards became a core requirement for jurisdictional REDD+ readiness and was tied to the delivery of finance for REDD+, Tanzanian officials recognized that it would be necessary for Tanzania to develop a policy on social and environmental safeguards in order to eventually access sources of finance for REDD+ and remain in compliance with its obligations under the UNFCCC. ${ }^{75}$ At the domestic level, the proponents of the REDD+ pilot projects also repeatedly pressed the National REDD+ Taskforce to adopt a set of social and environmental safeguards, with a particular emphasis on protections for the rights of local communities, as part of Tanzania's National REDD+ Strategy. ${ }^{786}$ In response, as was discussed in Section 4.4.2, the National REDD+ Taskforce developed a policy on social and environmental safeguards for REDD+ using the process and guidance set by the REDD+ SES Initiative. In other words, the National REDD+ Taskforce committed to an exogenous legal norm - the need to develop a set of social and environmental safeguards - because of the material benefits that it might gain in doing so (cost-benefit adoption) and due to the political pressure exerted by domestic civil society actors (mobilization).

Whereas the mechanisms of cost-benefit adoption and mobilization triggered the conveyance of legal norms relating to the development of social and environmental safeguards, the construction of the participatory rights of forestdependent communities in these safeguards are best explained by the mechanism of persuasive argumentation. A process of argumentation facilitated by the novelty of the pursuit of jurisdictional REDD+ efforts meant that

785 Interview 16 at 7; Interview 84 at 8; Nordeco \& Acacia, supra note 675 at 24.

786 Interview 23 at 2 and 8-9. See TFCG, "Feedback on the Tanzania National REDD Strategy, prepared by the REDD Pilot Projects" supra note 718 at 6; MJUMITA \& TFCG, "Five Steps to Get REDD Right(s)" supra note 718 at 2; TFCG et al., "Recommendations from Civil Society Organisations for Tanzania’s 2nd Draft National REDD+ Strategy and Draft Action Plan" supra note 732 at 3 . 
Tanzanian government officials were open to new normative understandings about the importance of social safeguards for REDD+, including those relating to the participatory rights of forest-dependent communities. ${ }^{787}$ Moreover, the flexible guidance set by the UNFCCC and the REDD+ SES Initiative for the development of a policy on social and environmental safeguards fostered the engagement of Tanzanian government officials in a deliberative discourse with other domestic actors and their international interlocutors around the nature and extent of participatory rights in the context of REDD+. ${ }^{88}$ In this process, the national consultant who facilitated the application of the REDD+ SES Initiative served as a key intermediary in ensuring that exogenous legal norms relating to participatory rights were effectively adapted to the Tanzanian context and appropriated by Tanzanian government officials. ${ }^{89}$ I thus argue that persuasive argumentation explains why and how exogenous legal norms that define the participatory rights of "Indigenous Peoples and local communities" in the Cancun Agreements and in the REDD+ SES were translated in line with existing endogenous norms in Tanzania and led to the construction of hybrid legal norms recognizing similar rights for "forest-dependent communities and marginalized communities," but not for Indigenous Peoples. ${ }^{79}$ In other words, the construction of hybrid legal norms relating to social and environmental safeguards for REDD+ in Tanzania also reflects the enduring influence of an endogenous norm that denies the status, existence, and rights of Indigenous Peoples. ${ }^{79^{1}}$ The resilience of this endogenous norm also explains

Interview 23 at 6-7. See Nordeco \& Acacia, supra note 675 at 24: "REDD+ Safeguards are an entirely new concept in Tanzania and a major investment of time and effort was needed to raise awareness regarding safeguards. Strong resistance to the concept of safeguards was expressed from some quarters of the NRTF during these early discussions. Following the recruitment of a national consultant and the development of a final list of principles, criteria and indicators, these discussions in Tanzania has evolved and matured significantly. There is now, among NRTF members, an acceptance of the importance of safeguards and a broad based consensus regarding the Tanzanian outputs to date, as well as consensus on moving forward to safeguard implementation. (...) So, while no impacts have been realised through the adoption of safeguards, (just as REDD+ implementation has yet to take place, beyond individual pilot projects), the validity and necessity of the concept has been well internalised among decision makers in Tanzania, and a strong basis exists for moving forward with subsequent support to safeguard implementation."

788 Interview 23 at $5 . \quad 789$ Interview 23 at 6-7.

$79 \circ$ Tanzania REDD+ Social and Environmental Standards, supra note 768, principles 2 and 4.

791 Interview 20 at 6 ("Who are the Indigenous people? We are all Indigenous anyway. (...) We have qualified that term slightly different. We consider them as forest dependent communities."); Interview 21 at 2 ("There are no Indigenous Peoples in Tanzania because all Tanzanians are indigenous. Living in a rural areas does not make someone any less Tanzanian or any more Indigenous. In fact, only South America has truly Indigenous Peoples.") 
why the material and social pressures to recognize the status and rights of Indigenous Peoples that were exerted by the Norwegian Embassy, the World Bank FCPF, and the UN-REDD Programme were ultimately unsuccessful in getting Tanzania to alter its position on this matter.

\subsection{REDD+ AND THE FUTURE OF INDIGENOUS AND COMMUNITY RIGHTS IN TANZANIA}

This chapter has shown that the pursuit of jurisdictional REDD+ activities has resulted in the enactment of an enhanced set of participatory and substantive rights for forest-dependent communities in Tanzania. Notwithstanding ongoing disagreements over the establishment of finance and benefit-sharing arrangements for REDD+, Tanzania's National REDD+ Strategy and its safeguards policy recognize the importance of respecting and protecting the participatory and substantive rights of forest-dependent communities in the design and implementation of REDD+ activities, including their right to free, prior, and informed consent. The long-term implications of these developments are hard to discern because the future prospects of jurisdictional REDD+ in Tanzania remain uncertain as of August 2014. At the moment, the Tanzanian government is aiming to obtain additional funding from the Norwegian government to complete its jurisdictional REDD+ readiness efforts. ${ }^{72}$ Without additional support from donors, the jurisdictional REDD+ readiness policies developed by Tanzania are unlikely to be implemented, ${ }^{793}$ which would not only limit the impacts of these policies on the ground, but also undoubtedly constrain their influence on the adoption of policies in related sectors such as forestry, agriculture, and social development. What is more, as Tanzania's economy becomes increasingly integrated into the global market for agricultural commodities, the Tanzanian government's interest in the implementation of jurisdictional REDD+ policies may further diminish. ${ }^{794}$

Nonetheless, there are two reasons to think the recognition of the rights of forest-dependent communities in the context of jurisdictional REDD+ might have durable effects. The first reason has to do with the fact that these rights constitute hybrid legal norms that were constructed on the basis of endogenous Tanzanian norms regarding the role of these communities in forest

793

794 See generally Eric F. Lambin \& Patrick Meyfroidt, "Global land use change, economic globalization, and the looming land scarcity" (2011) 108:9 PNAS 3465. 
governance as well as the nonexistence of Indigenous Peoples on Tanzanian soil. The legal norms relating to the rights of forest-dependent communities were effectively translated and appropriated by Tanzanian officials as well as domestic CSOs throughout the jurisdictional REDD+ readiness process. The enhanced normative resonance of these hybrid legal norms suggests they may influence Tanzania's law, policies, and practices in forest governance and other policy sectors in the years to come.

The second reason has to do with the many ways in which domestic CSOs have been empowered as a result of the jurisdictional REDD+ readiness phase. It is important to highlight that the relatively consultative manner in which jurisdictional REDD+ policies were elaborated, as reflected in the inclusion of representatives from CSOs in the National REDD+ Taskforce and its technical working groups and the organization of an iterative series of multi-stakeholder consultations and workshops, stands in sharp contrast to the usual policy-making practices that prevail in Tanzania. ${ }^{795}$ To the extent this precedent has redefined the expectations of government officials, domestic CSOs, and donors it may have durable implications for future policy-making processes in forestry and other sectors. ${ }^{796}$ Most importantly, given the resources, credibility, and capabilities that domestic CSOs have acquired as a result of the direct support they have received from Norway and their work in developing and implementing REDD+ projects on the ground, ${ }^{797}$ domestic CSOs are well-positioned to advocate for greater recognition of, and support for, the rights of forest-dependent communities in the context of the implementation of jurisdictional REDD+ policies as well as forest governance and policy more broadly. ${ }^{79^{8}}$

On the other hand, this chapter has also shown that the pursuit of jurisdictional REDD+ activities has done very little to foster recognition of and protection for the distinctive status and rights of Indigenous Peoples in

795 That is to say that the development of REDD+ policies in Tanzania was perfectly or completely inclusive. Among other shortcomings, the consultations included too many local government stakeholders and not enough civil society representatives. It also largely excluded Indigenous Peoples (Nordeco \& Acacia, supra note 675 at 11). And despite their participation in the policy-making process, it is hard to identify any concrete areas in which civil society managed to exert meaningful policy-making influence, apart from the creation of a policy on social and environmental safeguards.

796 Interview 15 at 13-14; Interview 52 at 14.797 See Section 5.3.

$79^{8}$ That said, the empowerment of these domestic CSOs should not be seen as equivalent to the direct empowerment of forest-dependent communities and villages. Indeed, most of these domestic CSOs only represent and serve the interests of local communities to the extent that this is consistent with their broader objectives of conserving forests, ensuring their sustainable management of forests or alleviating poverty. 
Indonesia. Their inclusion in a technical working group of the National REDD+ Taskforce was lauded as a "milestone"799 by international observers working on Indigenous rights and is viewed as an important development that created space for them to advocate for their rights. ${ }^{800}$ But the reality is that the National REDD+ Strategy and safeguards policy fail to recognize their very existence as defined under international law and creates risks that the implementation of jurisdictional REDD+ policies may only serve to further marginalize them. This is consistent with the Tanzanian government's continuing rejection of the application of the concept of Indigenous Peoples in international fora ${ }^{801}$ as well as pursuit of policies in which Indigenous Peoples continue to experience significant tenure insecurity. ${ }^{802}$

All told, the jurisdictional REDD+ readiness phase can be said to have reinforced endogenous legal norms and practices that have progressively given local communities greater rights and authority over their lands and forests over the last decade, while denying similar protections to Indigenous Peoples. As such, for good and for bad, the recognition and protection of rights in the context of the jurisdictional REDD+ cannot be divorced from the broader achievements and failures that various international and domestic actors have had in pressing for increased respect for human rights and local autonomy since the end of authoritarian socialism in Tanzania.

800 PINGOs Forum, Annual Report. 2012-2013. Report submitted to Oxfam Ireland (on file with the author) at $38-39$.

8 or Statement by H.E. Ambassador Ramadhan M. Mwinyi, Deputy Permanent Representative of the United Republic of Tanzania to the United Nations, during the 12th session of the Permanent Forum on Indigenous Issues, Agenda Item 4, "Half-Day Discussion on African Region,” (New York, 23 May 2013), available at: www.minorityvoices.org/force_download.p hp?file=data/files/final/news_1435/TanzaniagovernmentstatementtotheUN.pdf (accessed 19 December 2014) at 2: "The United Republic of Tanzania has always expressed reservations on the claim that indigenous communities exist in her jurisdiction."

802 For instance, a Maasai community in Northwestern Tanzania have faced eviction due to the proposed establishment of a private game reserve on their traditional lands. See Gerhard Jacobs, "Tanzania sells Masai people's land to Arab royals, who want to build a hunting reserve for the rich" available at: www.thesouthafrican.com/tanzania-sells-masai-peoples-la nd-to-arab-royals-who-want-to-build-a-hunting-reserve-for-royals/ (accessed 19 December 2014); David Smith, “Tanzania’s Masai 'breathe sigh of relief after president vows never to evict them," available at: www.theguardian.com/world/2014/nov/25/tanzania-masai-evictionuturn (accessed 19 December 2014). 


\section{5}

\section{Rights and Project-Based REDD+ in Indonesia and Tanzania}

\subsection{THE TRANSNATIONAL MARKET FOR PROJECT-BASED REDD+ ACTIVITIES}

There are two principal types of market interventions that are relevant to REDD+: those that focus on changing or managing the various global commodity supply chains that drive deforestation (such as timber, minerals, and agricultural products $)^{803}$ and those that seek to incentivize the pursuit of project-based REDD+ activities through the generation of credits for the voluntary carbon market. ${ }^{804}$ While efforts to create deforestation-free supply chains remain in their infancy, ${ }^{805}$ up to 350 REDD+ projects have been initiated in over fifty developing countries. ${ }^{806}$ Although project-based REDD+ activities may aim to contribute to a country's jurisdictional readiness efforts and may eventually be integrated into or regulated by a national REDD+ scheme as part of a nested approach, ${ }^{807}$ their primary focus lies in the reduction of carbon emissions from forestry-related sources in developing countries at the local level. ${ }^{808}$ When these projects are designed, implemented, and certified in line with the methodologies and processes set by a private carbon accounting program, they can generate Verified Emission Reductions (VERs) that can be

${ }^{803}$ Christopher Meyer \& Dana Miller, "Zero Deforestation Zones: The Case for Linking Deforestation-Free Supply Chain Initiatives and Jurisdictional REDD+" (2015) 34 Journal of Sustainable Forestry 559.

804 Sills et al., supra note 186.

805 Daniel Nepstad et al., "More Food, More Forests, Fewer Emissions, Better Livelihoods: Linking REDD+, Sustainable Supply Chains and Domestic Policy in Brazil, Indonesia and Colombia" (2013) 4:6 Carbon Management 639 at 642.

806 Annex I. Overview of REDD+ activities in the developing world.

807 Forest Trends and Climate Focus. Nested Approaches to REDD+: An Overview of Issues and Options, 2011.

$8 \circ 8$ CIFOR, "Global database of REDD+ and other forest carbon projects Interactive map," available at: www.forestsclimatechange.org/redd-map/ (accessed 13 December 2013). 
sold or traded on voluntary carbon markets. ${ }^{809}$ In 2014, transactions of VERs generated through REDD+ projects amounted to the top-selling project type in the voluntary carbon market, supplying 25 megatons of reductions in carbon emissions and generating 115 million US dollars. ${ }^{810}$

For several years, the carbon accounting program with the greatest share of REDD+ activities worldwide has been the VCS. Launched by The Climate Group, the International Emission Trading Association, and the World Business Council for Sustainable Development in 2005, the VCS aims to "provide a robust quality assurance standard for GHG emission reduction projects with the purpose of issuing credits for voluntary markets." ${ }^{811}$ The VCS provides the rules and requirements for the validation and verification of carbon emission reduction projects and endorses specific methodologies that may be used to fulfil these requirements for a given type of project. The VCS also approves the roster of independent third party auditors that validate and verify that a carbon mitigation project has complied with a VCS methodology. The end-result of this process is the issuance of Voluntary Carbon Units (VCU), which are meant to ensure that any VERs are real, measurable, permanent, additional, and do not lead to the temporary displacement of emissions. ${ }^{812}$

The VCS has approved ten methodologies for project-scale REDD+ activities as part of its Agriculture, Forestry and Other Land Use (AFOLU) Requirements. ${ }^{813}$ The VCS AFOLU requirements certify that a REDD+ project has resulted in VERs and leads to the issuance of VCUs that can be sold and traded through the voluntary carbon market. Given that the primary focus of the VCS standards and methodologies lies with the technical requirements for certifying reductions in carbon emissions and not the conditions required to generate environmental or social co-benefits, they include few references to issues relevant to the rights of Indigenous Peoples and local communities. ${ }^{814}$ Instead, the VCS AFOLU requirements refer to other standards

809 See Merger et al., supra note 185. $\quad{ }^{810}$ Hamrick et al., supra note 242 at 12-13.

81 VCS, "Our Mission," available at: http://v-c-s.org/who-we-are/mission-history (accessed 20 December 2013).

812 VCS, "VCS Program Guide," Version 3.5, 8 October 2013, available at: www.v-c-s.org/sites/ v-c-s.org/files/VCS\%20Program\%2oGuide\%2C\%20v3.5.pdf (accessed 20 December 2013).

813 VCS, "Agriculture, Forestry and Other Land Use (AFOLU) Requirements," Version 3.4, 8 October 2013, available at: www.v-c-s.org/sites/v-c-s.org/files/AFOLU\%2oRequirements\%2C\% 20v3.4.pdf (accessed 20 December 2013).

814 The VCS AFOLU Requirements most notably refer to "community forestry" as an eligible REDD+ project activity (VCS AFOLU Requirements, supra note 813 at 7) and specifically identify the prevention of the planned conversion of "community-owned forests to other nonforest uses" as an eligible REDD+ project activity (Ibid at 21). 
and materials, most notably including the CCB Standards, as providing appropriate guidance for the pursuit of social and environmental benefits beyond reductions in carbon emissions. ${ }^{815}$ In 2012, in order to solidify their respective roles and positions in the voluntary carbon market, the VCS and the CCBA collaboratively developed a streamlined process and a set of joint templates for the validation and verification of AFOLU projects (including REDD+ projects) that can issue VCUs that are then tagged with the CCB label. ${ }^{816}$ Dual certification under the VCS AFOLU and CCB Standards has accordingly become the leading practice in land-based climate mitigation activities around the world. ${ }^{817}$

\subsection{RIGHTS AND PROJECT-BASED REDD+ ACTIVITIES IN INDONESIA}

Since 2007, the estimated number of REDD+ projects carried out in Indonesia has varied between thirty and fifty, giving it the second largest number of REDD+ projects in the world (after Brazil) and the largest share of project-based REDD+ activities in Asia by far. ${ }^{818}$ These projects have been implemented by conservation NGOs, bilateral aid agencies, international organizations, district governments, or some combination thereof, ${ }^{819}$ and have been supported through amalgamations of public and private finance. ${ }^{820}$

815 Ibid at 6 .

816 VCS \& CCCB, "VCS+CCB Project Development Process," Version 3.0, 26 November 2012, available at: www.v-c-s.org/sites/v-c-s.org/files/VCS\% 20CCB\% 20 Guidance\% 20 Project\%20 Development\%20Process, \%20v3.o.pdf (accessed 20 December 2013).

817 Seventy-one percent of all forest carbon transactions in 2013 were certified under both the VCS and the CCB Standards (Peters-Stanley et al., supra note 209 at 58).

818 See CIFOR, "Global database of REDD+ and other forest carbon projects Interactive map" available at: www.forestsclimatechange.org/redd-map/ (accessed 10 June 2014); Institute for Global Environmental Strategies, "Indonesia REDD+ Readiness - State of Play” (November 2012), available at: http://redd-database.iges.or.jp/redd/download/link?id=13 (accessed 21 November 2014).

819 For instance, the Berau Forest Carbon Program is a REDD+ demonstration project that is being implemented by the district government of Berau, in collaboration with the Nature Conservancy, the Deutsche Gesellschaft für Internationale Zusammenarbeit, the World Agroforestry Centre, and other local NGOs. See Cut Augusta Mindry Anandi et al., "TNC's initiative within the Berau Forest Carbon Program, East Kalimantan, Indonesia” in Erin O Sills et al., eds., REDD+ on the Ground. A Casebook of Subnational Initiatives across the Globe (Bogor Barat, Indonesia: CIFOR, 2014) 362 at 364-365).

820 Most REDD+ projects have relied on aid funding, at least in their initial stages. By way of example, while the main proponent and funder of the Katingan Peatland Restoration and Conservation Project is a private Indonesian company, it has benefited from bilateral, multilateral, and nongovernmental support and assistance for its preparatory activities. See Yayan Indriatmoko et al., "Katingan Peatland Restoration and Conservation Project, Central Kalimantan, Indonesia," in Sills et al., supra note 819, 309 at 312. 
Some REDD+ projects have been led by government officials at the provincial or district level and have aimed to contribute to Indonesia's jurisdictional REDD+ readiness efforts. ${ }^{821}$ Most REDD+ projects have been established by NGOs or corporations with the goal of generating carbon credits for the voluntary carbon market, either as a means of ensuring sustainable flows of finance for forest conservation efforts ${ }^{822}$ or simply to make a profit. ${ }^{823}$ On the whole, the strategies and interventions adopted by the proponents of these projects to address the drivers of deforestation and forest degradation or enhance forest carbon stocks have varied considerably. They have most notably encompassed one or more of the following: providing payments for ecosystem services to local populations, rehabilitating forest ecosystems, demarcating forest boundaries, improving the monitoring and protection of forests, preventing the conversion of forests to agriculture, or developing or strengthening community forestry institutions and management practices. ${ }^{824}$

The pursuit of project-based REDD+ activities in Indonesia has been primarily regulated by the Ministry of Forestry. In 2009, the Ministry adopted a pair of regulations providing it with the power to authorize REDD+ demonstration activities as well as to issue licenses for activities that aim to sequester or store forest carbon. Although the latter regulation was not specifically designed for REDD+, it served as an initial regulatory framework for voluntary REDD+ activities in Indonesia. ${ }^{825}$ In April 2012, the Ministry of Forestry adopted a new regulation on "The Implementation of Forest Carbon" that provided new criteria, guiding principles, and processes for approving, evaluating, and monitoring both demonstration and voluntary REDD+ projects. ${ }^{826}$

821 NORAD, supra note 423 at 277. By way of example, the Berau Forest Carbon Program has been funded by multilateral and bilateral funds, has officially been designated as a REDD+ demonstration project by the Ministry of Forestry, and has been in close contact with policymakers and experts working on Indonesia's jurisdictional REDD+ readiness efforts. See Interview 73 at 2-3; Anandi et al., supra note 819 at 364-367.

822 Interview 46 at 1; Dian Yusvita Intarin et al., "Ketapang Community Carbon Pools, West Kalimantan, Indonesia" in Sills et al., supra note 819, 329 at 333-334.

823 This is most notably the case of the Rimba Raya Biodiversity Reserve Initiative, which has been implemented by a private firm, and which aims to sell carbon credits, at a profit, to foreign investors. See Yayan Indriatmoko et al., "Rimba Raya Biodiversity Reserve Initiative, Central Kalimantan, Indonesia" in Sills et al., supra note 819, 348 at 351.

824 Institute for Global Environmental Strategies, "REDD+ Projects. A Review of Selected REDD+ Project Designs" (February 2013), available at: http://redd-database.iges.or.jp/redd/ REDD+_Project_Booklet_En.pdf (accessed 9 December 2014) at 22.

825 Indrarto et al., supra note 428 at $75-77$.

826 Ministry of Forestry of the Republic of Indonesia, "Ministerial Regulation P. 2o/Menhut-II/ 2012 on Implementation of Forest Carbon," available at: http://theredddesk.org/sites/default/ files/ministerial_regulation_on_implementation_of_forest_carbon_3.pdf (accessed 9 December 2014). 
This regulation most notably authorizes the proponents of voluntary REDD+ projects to sell and trade carbon credits generated through their projects on domestic and international carbon markets. ${ }^{87}$ While this regulation encourages the empowerment of local communities within or beyond the forest area in which a REDD+ project is implemented, it does not include further guidance on the participation of communities, nor does it specify a mechanism for benefit-sharing. ${ }^{828}$ In practice, the proponents of REDD+ projects have also applied for other types of licenses that are directly related to the strategies for addressing the drivers of deforestation and forest degradation, such as a permit for the restoration of ecosystems ${ }^{829}$ or for community forestry. ${ }^{830}$ Finally, several provincial governments have also adopted regulations that govern the implementation of REDD+ activities, ${ }^{8}{ }^{31}$ and are furthermore involved in the approval process for other types of forest-related licenses. ${ }^{8}{ }^{32}$

Despite the abundance of interest and funding for project-based REDD+ activities in Indonesia, only two voluntary REDD+ projects have, as of June 2016, obtained the necessary set of licenses from the Ministry of Forestry: the Rimba Raya Biodiversity Reserve Initiative ${ }^{83}$ and the Katingan Peatland Restoration and Conservation Project. ${ }^{834}$ And while several projects are working toward obtaining private certification as REDD+ projects, only the former project has succeeded in being verified and validated under the VCS and the CCB Standards. ${ }^{8} 35$ The underwhelming progress of REDD+ projects in Indonesia can be explained by several factors: the delays and complexities involved in obtaining the necessary licenses and approvals from the Ministry of Forestry and other levels of government, ${ }^{836}$ limited technical and

827 Ibid at art. 8. ${ }^{828} \quad$ Ibid at art. 3(5). $\quad{ }^{829}$ Indriatmoko et al., supra note 820 at 326-327.

830 Intarin et al., supra note 822 at 334 .

831 Cut Augusta Mindry Anandi et al., "Ulu Masen REDD+ Initiative, Aceh, Indonesia” in Sills et al., supra note 819,380 at 381.

832 Intarin et al., supra note 822 at $345 . \quad 8_{33}$ Indriatmoko et al., supra note 823 at 348 .

834 Ibid at 310.

835 VCS Project Database, "Rimba Raya Biodiversity Reserve Project," available at: www.vcspro jectdatabase.org/\#/project_details/674 (accessed on 14 June 2016); CCBA, "Rimba Raya Biodiversity Reserve REDD Project,” available at: www.climate-standards.org/2010/06/08/ rimba-raya-biodiversity-reserve-redd-project/ (accessed 14 June 2016). Another project, the Ulu Masen Ecosystem Project had been validated under the silver level of the second edition of the CCB Standards, but its validation has since expired (CCBA, "Reducing Carbon Emissions from Deforestation in the Ulu Masen Ecosystem,” available at: www.climate-sta ndards.org/2007/11/o2/reducing-carbon-emissions-from-deforestation-in-the-ulu-masen-eco system/ (accessed 14 June 2016).

${ }_{3} 6$ Interview 46 at 4 and 8; Interview 61 at 6; Interview 85 at 5-6; Interview 88 at 3; Observations gathered during participation in Meeting of the REDD+ Partnership (Palangkaraya, Indonesia, October 2013); Indriatmoko et al., supra note 820 at 326-327; Intarin et al., supra note 822 at 346; Indriatmoko et al., supra note 823 at 359-360. 
institutional capabilities at the local level, ${ }^{837}$ the lack of clarity around forest and land rights, ${ }^{8}{ }^{8}$ the absence of support from local communities that have been skeptical of the relative benefits of REDD+ in comparison with other forest and land uses such as cash-crop agriculture, ${ }^{839}$ and the wavering and unpredictable levels of support that provincial and district governments may offer to environmental issues due to their close relationship with powerful industries such as agriculture, logging, and mining. ${ }^{8}{ }^{8}$

The ways in which these REDD+ projects have addressed or affected the rights of Indigenous Peoples and local communities have also varied significantly. On paper, most of the twenty-eight REDD+ projects that I reviewed were conceived in a manner that sought, directly or indirectly, to respect and support the participatory and substantive rights of Indigenous Peoples and local communities. Indeed, all of the REDD+ projects were designed to empower local communities to varying degrees or ensure their participation in some form in activities to reduce carbon emissions from forestry-based sources, and over 90 percent of projects planned to share benefits with local communities or provide them with capacity-building opportunities and alternative livelihoods. On the other hand, a much smaller share of REDD+ projects - about half - were developed with the objective of strengthening the land tenure and forest rights of local communities. ${ }^{84}$

My findings regarding the early implications of twenty-two of these REDD+ projects for the rights of Indigenous Peoples and local communities reveal the gap that may exist between commitments to rights and their implementation in the context of a REDD+ project. ${ }^{82}$ While I found that close to 86 percent of projects had engaged with local communities or ensured their participation in the design and implementation of REDD+ activities, only half of these projects had managed to improve livelihoods, build capacity, engage in benefit-sharing, or strengthen community land tenure and forest rights. ${ }^{843}$ All told, there is considerable variation in the approach and performance of REDD+ projects with respect to the rights of Indigenous Peoples and local

839 Intarin et al., supra note 822 at 346; Anandi et al., supra note 831 at 394.

840 Interview 46 at 4 ; Interview 60 at 10; Interview 89 at 4 ; Anandi et al., supra note 831 at 387.

841 Jodoin \& Hansen, supra note 149 at 2-22.

$84^{2}$ This analysis is limited to the 22 REDD+ projects for which it was possible to gather information about impacts as of June 2016.

843 See Jodoin \& Hansen, supra note 149 at 2-22. 
communities in Indonesia. On the positive side of the spectrum, several REDD+ projects have developed comprehensive approaches for engaging with local communities throughout the design and planning of a project, with the aim of ensuring their full and effective participation and maximizing potential social benefits. ${ }^{844}$ In addition, numerous REDD+ projects have sought to empower local communities by providing them with improved livelihoods, training, and employment opportunities, or sharing economic benefits with them. ${ }^{845}$ Finally, an important subset of projects have pursued the recognition and protection of the land and forest rights of Indigenous Peoples and local communities as a key intervention for reducing carbon emissions, ${ }^{84}$ including by facilitating the challenging process

844 See in particular Anandi et al., supra note 819 at 368-369 (describing the approach taken by the "Berau Forest Carbon Program" (The Nature Conservancy)). See also the following projects in Jodoin \& Hansen, supra note 149: "Promoting partnership efforts to reduce emissions from deforestation and forest degradation of tropical peatland in south Sumatra through the enhancement of conservation and restoration activities" (Regional Research Center of South Sumatra); "Poigar Forest, North Sulawesi" (ONF International and Green Synergies); "Mawas Peatland Conservation Project" (Winrock International); "Leuser Ecosystem REDD Project" (Global Eco Rescue (GER)); "Community Carbon Measurement in Kutai Barat" (WWF-Indonesia \& University of Copenhagen); "Katingan Peat Forest Restoration Project, Central Kalimantan" (PT Rimba Makmur Utama Katingan); and "Ketapang Community Carbon Pools" (Fauna \& Flora International).

845 See the following projects in Jodoin \& Hansen, supra note 149: "Berau Forest Carbon Program” (The Nature Conservancy); "Berbak Carbon Initiative” (Zoological Society of London (ZSL)); "Ulu Masen Ecosystem Project" (Aceh Provincial Government; Carbon Conservation; and Fauna \& Flora International); "Promoting partnership efforts to reduce emissions from deforestation and forest degradation of tropical peatland in south Sumatra through the enhancement of conservation and restoration activities" (Regional Research Center of South Sumatra); "Mawas Peatland Conservation Project" (Winrock International); "REDD and Enhancing Carbon Stocks in Meru Betiri National Park, Java" (Indonesian Ministry of Forestry, the MBNP, ITTO, Seven \& i Holdings and others); "REDD Project in Kutai Barat, West Kalimantan” (WWF-Indonesia); "Sulbar Habitat, West Sulawesi” (Keep the Habitat); “Avoided Deforestation Project in Malinau, East Kalimantan” (Global Eco Rescue (GER)); "Forest Resources Management for Carbon Sequestration" (CARE International Indonesia); "Rimba Raya Biodiversity Reserve Project” (InfiniteEARTH); "Katingan Peat Forest Restoration Project, Central Kalimantan" (PT Rimba Makmur Utama Katingan); “IUCN Towards Pro-poor REDD+ Project” (IUCN); and "Ketapang Community Carbon Pools” (Fauna \& Flora International).

846 Interview 46 at 1: "We started working with NGOs in that area in 2006, and the reason I went there was looking at how we could support NGOs more in the part in habitat management and the threat to tigers outside of the park boundary. Was also timed nicely with some regulatory changes in Indonesia which permit communities to access greater rights over state forest lands. Which allows communities to apply for a private licence over lands within the administrative boundaries of their villages. We saw that as one strategy for getting really critical areas outside of the formally protected area into new types of management and empower local communities in that process. My work really came out of a strategy for trying to take state forest lands out of the running for other potential uses. As in logging or oil palm." 
obtaining a hutan desa license for the communities that they work with ${ }^{847}$ or supporting the participatory mapping of customary forests. ${ }^{84^{8}}$ It is important to highlight that while most REDD+ projects in Indonesia have been set up in areas inhabited or used by adat communities that identify as Indigenous, few projects have tried to distinguish between Indigenous and non-Indigenous communities in the design and implementation of project activities. This lack of differentiation is most notably reflected in the decisions of several projects to apply the principle of free, prior, and informed consent to all communities in their project areas ${ }^{849}$ and to apply for a hutan desa license (rather than seek legal recognition of adat rights to forests). ${ }^{850}$

On the negative side of the spectrum, a few REDD+ projects in Indonesia have failed to fully consider or respect the participatory rights of Indigenous Peoples and local communities. In particular, due in part to delays in the development and approval of projects, the proponents of several REDD+ projects have not effectively engaged with local communities and gained their support for the implementation of REDD+ activities. ${ }^{851}$ However, these projects are essentially moribund and have not managed to become operational. ${ }^{852} \mathrm{As}$ far as livelihoods might be concerned, only two particular REDD+ projects - the Kampar Peninsula Carbon Reserve and the Tesso Nilo Bukit Tigapuluh REDD Project - have been criticized for the restrictions that they have imposed on the agricultural practices of local communities near the project area. ${ }^{853}$ Beyond

See Anandi et al., supra note 819 at 378 ; Intarin et al., supra note 822 at 346.

See NORAD, supra note 423 at 277-278; Indriatmoko et al., supra note 820 at 315; IUCN, "IUCN REDD+ Project in Indonesia Supports Customary Land Mapping," available at: www.iucn.org/news_homepage/news_by_date/?13413/IUCN-REDD-Project-in-IndonesiaSupports-Customary-Land-Mapping (accessed 7 January 2014).

Interview 46 at $9 . \quad 850 \quad$ Interview 88 at 4 .

Indriatmoko et al., supra note 823 at 360; Sunderlin et al., supra note 47 at 48.

See, in particular, with respect to the "Ulu Masen Ecosystem Project" (Aceh Provincial Government; Carbon Conservation; and Fauna \& Flora International): Anandi et al., supra note 831 at 388-389; Lesley McCullogh, "Ulu Masen REDD Demonstration Project. The Challenges of Tackling Market Policy and Governance Failures that Underlie Deforestation and Forest Degradation" (IGES, July 2010) at 15-18; Patrick Anderson \& Marcus Colchester, "Local Forest Governance, Free, Prior and Informed Consent and REDD+ in Indonesia: A Case Study from Aceh, Sumatra" in Holly Jonas, Harry Jonas \& Suneetha M. Subramanian, eds., The Right to Responsibility: Resisting and Engaging Development, Conservation, and the Law in Asia (Natural Justice and the United Nations University, 2013) 176 at 180-185.

See Forest Peoples Programme, "Sumatra: Update on RAPP's Activities in the Kampar Peninsula, Riau," Rights, Forests and Climate Briefing Series (October 2011), available at: www.forestpeoples.org/sites/fpp/files/publication/2011/10/kampar-peninsula-briefing-5.pdf (accessed 4 December 2014) at 2; World Growth, chapter 5: "Case Study: Failure of Protected Areas" in "REDD Conservation: Avoiding The New Road To Serfdom: A World Growth Report" (December 2010), available at: http://worldgrowth.org/site/wp-content/uploads/2012/ o6/WG_REDD_Conservation_Report_12_10.pdf (accessed 11 June 2016) at 27. 
these two projects, there are no known cases where the land and resource rights of Indigenous Peoples or local communities have actually been negatively affected by a REDD+ project in Indonesia.

This analysis of project-based REDD+ activities in Indonesia reveals the potent, yet limited set of opportunities offered by the transnational legal process for REDD+ for the recognition and protection of the rights of Indigenous Peoples and local communities in developing countries. On the one hand, most REDD+ projects in Indonesia have effectively extended participatory rights to both Indigenous Peoples and local communities. Many projects have also sought to empower local communities through capacity-building, livelihood programs, and benefit-sharing, but have not managed to fully implement benefit-sharing arrangements. On the other hand, most projects have neither tackled the challenges associated with recognizing and protecting the land and forest tenure rights of Indigenous Peoples and local communities, nor have they contributed to the broader struggle of Indigenous Peoples seeking to have different actors in Indonesian society recognize their distinctive status, rights, and institutions.

\subsection{RIGHTS AND PROJECT-BASED REDD+ ACTIVITIES IN TANZANIA}

As part of Norway and Tanzania's bilateral climate change partnership, the Norwegian Embassy and the National REDD+ Taskforce agreed to fund a number of pilot projects to experiment with the implementation of REDD+ at the local level and generate lessons for the development of Tanzania's National REDD+ Strategy. ${ }^{854}$ The priority areas pursued in these projects included resolving local governance and tenure challenges; designing incentive and benefit-sharing schemes; testing methods for measuring deforestation and carbon sequestration, including participatory approaches; identifying and addressing the drivers of deforestation and degradation; and building capacity for climate adaptation and mitigation. ${ }^{855}$ Through a competitive application process, the Norwegian Embassy and the National REDD+ Taskforce

${ }^{84}$ Interview 52 at 7 . See also Deloitte, Mid-term Review Report of Nine NGO REDD+ Pilot Projects in Tanzania - Higher-Level Overview of NGO REDD+ Portfolio, (17 August 2012) (on file with the author) at 4 .

${ }_{55}$ National Taskforce for Developing the National REDD Strategy, "Guidelines for Review of NGOs/CSOs Proposals to be Funded by the Norway-Tanzania REDD Initiative" in URT, "National Framework for REDD," supra note 684, 34 at 35. 
worked together to selected ten pilot projects from among forty-six proposals submitted by conservation and development NGOs. Nine of these pilot projects eventually became operational, each covering a different region of Tanzania. ${ }^{856}$

While two of the pilot projects focused on experimenting with methodologies for measuring forest carbon stocks and changes therein, ${ }^{857}$ the other seven projects focused on reducing carbon emissions from forest-based sources through a range of interventions, such as the adoption of alternative livelihoods, technologies, and agricultural practices, the development of forest management plans, and the formalization of village land rights over forests. ${ }^{85}$ Most of these projects originally aimed to generate carbon credits in line with the verification and validation processes set by the VCS and the CCBA. According to an independent review, project developers had underestimated the technical challenges, costs, and delays associated with the certification process and were moreover constrained by the low cost of carbon on voluntary markets. ${ }^{859}$ From 2009 to 2015, only one of these pilot projects managed to prepare and submit a project design document for validation and verification by third-party auditors under the VCS and CCB certification programs. ${ }^{860}$ In addition to the REDD+ projects funded through the Norwegian-Tanzanian bilateral agreement, a Tanzanian NGO succeeded in designing and implementing a REDD+ project in the Yaeda Valley in Northern Tanzania. ${ }^{861}$ This REDD+ project was developed and validated under the Plan Vivo Standard, which "is a certification framework for community-based Payments for Ecosystem Services (PES) programmes supporting rural smallholders and community groups with improved natural resource management." ${ }^{862}$

Interview 20 at 3; Interview 52 at 6-7. National REDD+ Secretariat, "Tanzania's REDD Readiness Sites for REDD Pilot Projects" (on file with the author).

These two projects were the "REDD Readiness in Southwest Tanzania" (Wildlife Conservation Society) and "Enhancing Tanzanian Capacity to Deliver Short and Long Term Data on Forest Carbon Stocks across the Country" (WWF Tanzania). See Jodoin \& Hansen, supra note 149 at 29-31.

Deloitte, supra note 854 at 5-6.

Merja Mäkelä et al., "Lessons learned from the implementation of REDD Pilot Projects in Tanzania. 2009-2014" (NIRAS, July 2015) (on file with the author) at 28-31.

60 This is the project by the Tanzanian Forest Conservation Group. See CCB Standards Project Database, "MJUMITA Community Forest Project (Lindi)," available at: www.climate-stan dards.org/2014/05/08/mjumita-community-forest-project-lindi/ (accessed 4 November 2014). Carbon Tanzania, "Reducing Emissions from Deforestation and Forest Degradation in the Yaeda Valley, Northern Tanzania. Project Design Document” (January 2015), available at: www.planvivo.org/docs/Yaeda_REDD_PDD_Jan15.pdf (accessed 21 April 2016).

Plan Vivo Foundation, "The Plan Vivo Standard For Community Payments for Ecosystem Services Programmes" (2013), available at: www.planvivo.org/wp-content/uploads/Plan-VivoStandard-2013.pdf (accessed 21 April 2016) at 2. Unlike the CCB standards, Plan Vivo serves as a standalone, comprehensive certification program that not only demonstrates the delivery of 
My analysis of these ten REDD+ projects reveals that all but one has had some positive implications for local communities. ${ }^{86}$ To begin with, a concern for communities, rights, participatory forest management, or the equitable sharing of benefits formed part of the very purpose of eight of these ten projects. ${ }^{864}$ With respect to participatory rights, nine of the ten projects ${ }^{865}$ were ultimately implemented in a manner that sought to engage with communities and benefit from their input and participation. ${ }^{866}$ While only two projects explicitly incorporated the principle of FPIC in their initial design, ${ }^{867}$ at least two other projects integrated this principle in the course of implementing their activities. ${ }^{868}$ Other projects engaged with local communities through a range of participatory practices such as consultations and the provision of information regarding the pursuit of REDD+ activities. ${ }^{869}$

Seven of the ten REDD+ projects pursued in Tanzania had positive implications for the substantive rights of local communities, by providing them with alternative livelihoods, employment, or capacity-building. ${ }^{870}$ Only five projects were able to successfully test benefit-sharing mechanisms in the form of direct payments to communities, ${ }^{871}$ a finding that reflects the costs and complexities of REDD+ projects and the limited financial opportunities offered by voluntary carbon markets. ${ }^{872}$ One REDD+ project, pursued by the African

significant benefits for climate mitigation, community well-being and biodiversity but also generates VERs in the form of Plan Vivo Certificates.

The exception is the project by the Wildlife Conservation Society of Tanzania. See Jodoin \& Hansen, supra note 149 at 30-31.

exception being the project by the Wildlife Conservation Society of Tanzania.

Ibid at 15-23. See also Mäkelä et al., supra note 859 at 18-20 and Deloitte, supra note 854 at 11:

"The projects within the portfolio have worked successfully to include all relevant stakeholders in the design and implementation of project activities."

See Kate Forrester Kibuga, Nuru Nguya, Hassan Chikira, Bettie Luwuge \& Nike Doggart, "Integrating the principles of free, prior and informed consent in the establishment of a REDD project: a case study from Tanzania" (Making REDD work for communities and forest conservation in Tanzania, TFCG Technical Report 27, February 2011) (on file with the author) and Carbon Tanzania, supra note 861 at 19.

Mäkelä et al., supra note 861 at 19 .

869 Deloitte, supra note 854 at 13: "The entire portfolio conducted widespread community engagement activities as part of the FPIC process. Due to past experiences in some of the project areas related to resettlement, there was initial hesitation from communities to participate. The NGO's made it clear that communities not wishing to participate had this choice available to them." See also Interview 12 at 10; Interview 22 at 2; Interview 29 at 7.

870 Jodoin \& Hansen, supra note 149 at $23-33$.

${ }^{871}$ Mäkelä et al., supra note 859 at 22; Deloitte, supra note 854 at 5-6; and Carbon Tanzania, supra note 861 at $21-22$.

${ }_{72}$ Zahabu \& Malimbwi, supra note 51 at 145 . 
Wildlife Foundation, was found to have positive implications for some communities (through enhancements in sustainable agriculture), but negative implications for other individuals (specifically cattle owners and the poorest members in these communities). ${ }^{873}$ The disappointing outcomes of this project highlight the challenges of implementing REDD+ projects in complex environments involving multiple communities and individuals that use and depend upon resources in different, sometimes conflicting ways.

To be sure, the most important benefit provided by the projects related to enhancements in land tenure security and the devolution of authority over forests. ${ }^{874}$ Five of the nine pilot projects directly or indirectly led to the clarification of the land and tenure rights of local communities through the establishment of new village land-use plans and village forest reserves under the CBFM regime or joint management plans under the JFM regime laid out in the Forest Act. ${ }^{875}$ An independent review of the pilot projects completed in 2012 found as follows:

The projects in the portfolio are achieving significant success in securing formal legal acknowledgement of local forest resources. This incentive scheme is based on the assumption that people will protect and invest in the forest if they can later benefit from the results. Pilot projects have successfully supported communities in gaining land tenure and user rights for significant areas of forest on a range of land types including general land, community land, and government forest reserves. In some projects, formal land tenure was granted to individual farmers. The projects have also developed, in collaboration with communities, forest management plans that regulate resource extraction and ensure that benefits from resource extraction flow not only to elites. Communities, through the use of patrols, have sought to protect and conserve their forest resources now that they have formal rights to these areas. To date, this incentive scheme is working well and has yielded significant conservation results as communities are taking a more active role in forest management. Community members also expressed high levels of gratitude for this component of the projects and view it as a tangible benefit of project activities. ${ }^{876}$

In addition, the Yaeda Valley REDD+ Project has also strengthened the land tenure held by the Hadza people through a certificate of customary ownership

873 NIRAS Finland Oy, "Final Review of the Project African Wildlife Foundation Advancing REDD in the Kolo Hills forest” (June 2015) (on file with the author) at 22.

874 Mäkelä et al., supra note 859 at 12.

875 Jodoin \& Hansen, supra note 149 at 23-33. See also Deloitte, supra note 854 at 7 ; Mäkelä et al., supra note 859 at 16 .

${ }_{876}$ Deloitte, supra note 854 at 6 . See also findings by Sunderlin et al., supra note 47 at 46 and Therese Dokken et al., "Tenure Issues in REDD+ Pilot Project Sites in Tanzania” (2014) 5(2) Forests 234 at 250-251. 
that they had previously obtained under the Village Land Act. ${ }^{877}$ While most of the REDD+ projects in Tanzania succeeded in providing communities with enhanced rights and tenure security over their lands and forests, it is important to stress that the potential of REDD+ projects operating at the local level to transform the system for land tenure in Tanzania was naturally contingent on the collaboration of district officials as well as legal and policy developments at the national level. ${ }^{878}$

While the majority of these REDD+ projects enhanced the participatory and substantive rights of local communities, they had few direct implications whether positive or negative - for the rights of Indigenous Peoples. Indeed, none of the pilot projects funded through the Norwegian-Tanzanian bilateral agreement were implemented on or near forests or lands managed, occupied, or used by Indigenous hunter-gatherers or pastoralists. The neglect of Indigenous Peoples in the overall portfolio of the pilot projects resulted from the bias in the selection process for projects that would operate through CBFM or JFM ${ }^{879}$ regimes under the Forest Act, which are generally considered inaccessible to Indigenous Peoples under Tanzanian law. ${ }^{880}$ As a result, in their implementation of rights such as the right to free, prior, and informed consent, the proponents of REDD+ pilot projects were largely unconcerned with the status of the local communities they worked with and sought instead to apply this right to all local communities that might be affected by their interventions. ${ }^{881}$ The sole and important exception is the Yaeda Valley REDD+ Project, which was pursued by Carbon Tanzania in collaboration with the hunter-gatherer Hadzabe and pastoralist communities in Mongo Wa Mono and Domanga villages. ${ }^{88 z}$ Unlike

Carbon Tanzania, supra note 861 at $14-15$.

This is identified as a key lesson of the implementation of the REDD+ pilot projects in Tanzania. See IUCN Tanzania Office, "Lessons Learned and Best Practice from REDD+ Pilot Projects" (12 September 2013) (on file with the author) at 6 and Mäkelä et al., supra note 859 at 14 . This is also a point made by Sunderlin et al., in their broader review of the implications of REDD+ projects for tenure problems: Sunderlin et al., supra note 47 at 49 . Interview 52 at 13 ; Interview 65 at $3 . \quad 880 \quad$ See Section 4.1.

Interview 12 at 11. See Kibuga, supra note 867 at 16: "Much of the literature about FPIC deals with indigenous peoples however there is growing recognition that the principles should also be applied to local communities, particularly in the context of REDD. For example, the draft UN-REDD programme guidelines for FPIC, refer to both indigenous peoples and forest dependent communities. Similarly the LCA negotiating text refers to both indigenous peoples and local communities and recently published guidelines on FPIC in REDD+ by RECOFTC and GIZ discuss FPIC in the context of both local communities and indigenous peoples. Nonetheless, much of the literature, and in particular several reports produced by Forest Peoples Programme, who support the rights of peoples who live in forests and depend on them for their livelihoods, are focused specifically on indigenous peoples. One challenge in applying FPIC to local communities is that the term can be legally imprecise in some contexts."

Carbon Tanzania, supra note 861 at 13-14. 
the REDD+ pilot projects funded through the Norwegian-Tanzania bilateral agreement, the Yaeda Valley REDD+ Project was designed and implemented in a manner that recognized the traditional rights and knowledge held by Indigenous Peoples. ${ }^{883}$

The exclusion of Indigenous Peoples from the development of most REDD+ projects in Tanzania has meant that their lands and rights have not been threatened by the pursuit of REDD+, as might have been feared based on their political and economic marginalization. At the same time, Indigenous Peoples have not significantly benefited from the pursuit of project-based REDD+ activities in Tanzania. With the exception of the Yaeda Valley REDD+ Project, Indigenous Peoples have not been able to take advantage of the opportunities that REDD+ has created for securing or strengthening rights to land and tenure or enhancing livelihoods. In addition, the relegation of Indigenous Peoples from the selection of REDD+ pilot projects significantly limited their ability to advocate for the recognition and protection of their rights within the National REDD+ Strategy. None of the proponents of the pilot projects emphasized the importance of Indigenous rights in their discussions with the National REDD+ Taskforce ${ }^{884}$ and representatives from Carbon Tanzania - the only NGO that was collaborating with Indigenous Peoples were ignored by the National REDD+ Taskforce. ${ }^{885}$ Even as they called for greater respect for the rights of local communities and the participation of civil society in the development of the National REDD+ Strategy, the proponents of the pilot projects omitted any references to the status and rights of Indigenous Peoples in their policy briefs on the National REDD+ Strategy. ${ }^{886}$

Consequently, the ultimate implications of the implementation of REDD+ projects in Tanzania are thus largely consistent with the outcomes of jurisdictional REDD+ readiness activities. In essence, most REDD+ projects provided the means and impetus to implement the CBFM and JFM regimes under the Forest Act and thus provided forest-dependent communities with greater rights to govern and manage their forests as a result. Most REDD+ projects also achieved gains in livelihoods and income for forest-dependent

$88_{3}$ Interview 30 at 3; and Jodoin \& Hansen, supra note 149 at $32-33$.

884 Ibid at 39: "In particular, to correspond to the Tanzanian situation, TFCG could advocate for the debate on FPIC to be broadened to include local communities, rather than just indigenous peoples."

885 Interview 30 at 2.

886 See generally MJUMITA \& Tanzania Forest Conservation Group, “A one-step guide to making the National REDD strategy more pro-poor" supra note 718; Tanzania Forest Conservation Group, "Feedback on the Tanzania National REDD Strategy, prepared by the REDD Pilot Projects" supra note 718; MJUMITA and Tanzania Forest Conservation Group, "Five Steps to Get REDD Right(s)" supra note 718. 
communities. Conversely, Indigenous Peoples were ignored by the interventions and policy activities pursued by REDD+ pilot projects and were thus not provided with an important opportunity to use project-based REDD+ as a vehicle to gain greater recognition for their status, role, and rights in the governance of forests in Tanzania.

\subsection{EXPLAINING THE CONVEYANCE AND CONSTRUCTION OF RIGHTS IN PROJECT-BASED REDD+ ACTIVITIES IN INDONESIA AND TANZANIA}

My analysis of the design and outcomes of REDD+ projects in Indonesia and Tanzania shows that while most of these REDD+ projects have enacted and implemented legal norms relating to the participatory rights of local communities and the need to generate and share socioeconomic benefits, there is considerable variation across both countries in terms of the recognition and protection of forest, land tenure, and resource rights. While it is not feasible for me to explain why and how these rights were conveyed and constructed across every single one of these thirty-eight REDD+ projects, I can nonetheless formulate probable explanations that may account for these broad trends in the recognition and protection of rights across these two countries.

On the whole, I posit that the conveyance of legal norms relating to participatory rights and benefit-sharing in the design and implementation of a majority of REDD+ projects in Indonesia and Tanzania can be primarily explained by the causal mechanisms of cost-benefit adoption, élite internalization, and cost-benefit commitment. In the first instance, the requirements set by the CCB Standards appear to have been an important instrumental motivation for the proponents of REDD+ projects in Indonesia to enact and implement exogenous legal norms relating to participation of, and benefitsharing with, Indigenous Peoples and local communities. In particular, given that most of these REDD+ projects were established with the aim of eventually generating carbon credits that could be sold on the voluntary carbon market through dual certification under the VCS and CCB, respecting standards in relation to participation and benefit-sharing was seen as necessary in order to retain or gain access to most private and public sources of international carbon finance. ${ }^{887}$ In this context, it seems likely that many project developers believed the benefits of complying with exogenous legal norms

$88_{7}$ With respect to Indonesia, see Interview 46 at 9; Interview 60 at 4 . With respect to Tanzania, see Interview 12 at 11; Interview 22 at 2; Interview 23 at 9; Interview 29 at 7; Interview 52 at 6; and Mäkelä et al., supra note 859 at 20. 
relating to the right to free, prior, and informed consent or benefit-sharing exceeded the costs of doing so.

In the second instance, I argue that the proponents of REDD+ projects also enacted these legal norms and sought to implement them because they had internalized the view that doing so was integral to the success of their projects. As a result of a broader process of persuasive argumentation that has reshaped the field of conservation over the last two decades, project developers have increasingly understood that ensuring the participation of communities and sharing benefits with them is critical for guaranteeing their collaboration ${ }^{888}$ as well as securing the sustainability of REDD+ projects in the long-term. ${ }^{889}$ This belief was likely reinforced in the context of the design and implementation of REDD+ projects in Indonesia because of the possibility for communities to benefit from employment and other forms of income provided by competing activities that reduce forest cover such as those on palm oil plantations. ${ }^{80}$ In Tanzania, the commitment to participatory rights and community empowerment was instead reinforced by existing norms relating to the appropriateness of community-based approaches to forest governance that have taken hold since the early 2000 s. $^{891}$

In the third instance, I argue that the conveyance of legal norms relating to participation and benefit-sharing ultimately triggered a process of construction in which these legal norms were adjusted to the particular context in which REDD+ projects were designed and implemented through the causal mechanism of cost-benefit commitment. Although most REDD+ projects in both countries sought to respect the participatory rights of local communities and share benefits with them, the specific modes and interventions through which they did so varied considerably. ${ }^{892}$ In general, there are multiple tools, approaches, and methodologies for ensuring the participation of local and

See Interview 46 at 9: "In terms of our license to operate and not be involved in any kind of conflict, FPIC is very important. For our conservation objectives, unless there is buy in (either from the managers of the land or from others who are involved in using that land) then it's going to be very difficult to be successful. It's about levels of acceptance of the project." See Interview 12 at 11: "We can't move forward on any of these projects unless the communities are with us. (...) This has to be a community driven thing so we have to get the community on our side. The key thing is to ensure the sustainability. These projects are thirty or forty year programs. We are only going to be there with our Norwegian funding for a few years. What happens when that goes. We have to make sure that the community right from the beginning are aware of that. When so many aid projects just fizzle when the donor money disappears. REDD is one of those which ... it needs to last for a long time." See also Interview 23 at 4 ; Interview 52 at 6; and Interview 60 at 4.

$890 \quad$ Interview 88 at $4 . \quad{ }^{81} \quad$ See Section 5.1.

$892 \quad$ See Jodoin \& Hansen, supra note 149 at 2-22. 
conceiving benefit-sharing arrangements. ${ }^{893}$ Whether and how to engage and empower local communities in the design and implementation of a REDD+ project can be expected to depend on numerous factors, including the resources available to project proponents, the extent to which the collaboration of local communities is required to address the underlying drivers of deforestation and forest degradation, the needs and priorities of local communities in terms of social development and poverty alleviation, and existing institutional arrangements for participation and benefit-sharing. ${ }^{894}$ As such, I posit that the design of many REDD+ projects results from the construction of hybrid legal norms in which exogenous legal norms are rationally calibrated and adjusted in order to craft redesigned solutions to achieve the objective of addressing the local drivers of deforestation and reducing carbon emissions from forest-based sources. ${ }^{895}$

These three causal mechanisms also help explain why REDD+ projects in Indonesia and Tanzania have accorded almost no attention to the distinctive status and rights of Indigenous Peoples. ${ }^{896}$ First, as was discussed in Section 2.5, the CCB Standards have extended similar rights and protections to both Indigenous Peoples and local communities. This effectively eliminated any market incentive for project developers to distinguish between these two categories in the design and implementation of REDD+ projects. Second, the shared understanding that many conservation practitioners held regarding the importance of engaging with and empowering local communities in REDD+ was primarily based on whether their collaboration was essential to the success of a project. As such, the distinctive status of Indigenous Peoples was simply not germane to the underlying instrumental logic that is reflected in this broader belief in the benefits of participation and benefit-sharing. ${ }^{897}$ Third, the

893 See, e.g., Essam Yassin Mohammed, "Pro-poor benefit distribution in REDD+ Who gets what and why does it matter?” IIED REDD Working Paper (2011), available at: http://pubs .iied.org/pdfs/16508IIED.pdf. See also Lawlor et al., supra note 12 at 304-305 and 313-314.

894 See generally on the varying approaches and outcomes of REDD+ projects: Awono, Abdon et al., "Tenure and participation in local REDD+ projects: Insights from southern Cameroon" (2014) 35 Environmental Science \& Policy 76; Davide Pettenella \& Lucio Brotto, "Governance features for successful REDD+ projects organization" (2011) 18 Forest Policy E Economics 46; Sunderlin et al., supra note 47.

895 Of course, this micro-level process of cost-benefit commitment is itself shaped by the norms generated through macro-level processes of persuasive argumentation.

896 Indeed, with the notable exception of "REDD Project in Kutai Barat, West Kalimantan" (WWF-Indonesia), which refers to "local and Indigenous communities," other REDD+ projects in Indonesia and Tanzania eschewed references to the term "Indigenous" in their design documents. See Jodoin \& Hansen, supra note 149 at 2-22.

897 See, e.g., Interview 61 at 5: "From an instrumental approach, communities are better managed than governments are. That evidence has been borne out. The whole notion is to keep the forest standing carbon wise. The notion is that indigenous and other communities 
distinction between Indigenous Peoples and local communities was not particularly relevant to the local context in which many REDD+ projects were implemented. In particular, given the fact that most of the REDD+ projects in Tanzania were implemented on or near lands occupied or used by Indigenous Peoples, there was little need for the proponents of these projects to distinguish between Indigenous and non-Indigenous communities in their work. ${ }^{898}$

Although most REDD+ projects have enacted or implemented legal norms relating to participation and benefit-sharing in broadly similar proportions in Indonesia and Tanzania, the way in which they have addressed forest, land tenure, and resource rights has varied considerably. Indeed, while 80 percent of REDD+ projects in Tanzania included the strengthening of the forest and tenure rights of local communities as a key project outcome, only 50 percent of REDD+ projects in Indonesia did so. In addition, REDD+ projects in Tanzania have generally been much more successful in securing and clarifying land tenure for local communities than the REDD+ projects pursued in Indonesia. I argue that this disparity in outcomes may be explained by the weaker recognition of community forest rights in the CCB Standards and the enduring influence of national factors in shaping the design and implementation of REDD+ projects.

Whereas the third edition of the CCB Standards requires that project developers respect the participatory rights of local communities (criterion $\mathrm{G}_{3}$ ) and generate net positive community impacts (criterion $\mathrm{CM}_{2}$ ), the obligations they set in relation to forest, land tenure, and resource rights are less stringent. The third edition of the CCB Standards requires that project developers respect the statutory and customary land and forest rights of local communities (indicator G5.1-3), identify unresolved land rights and tenure conflicts, and describe the measures needed or adopted to help resolve these conflicts (indicator G5.4). The CCB Standards do not, however, actually require a REDD+ project to

are given a set of governance mechanisms, are better managers." See also Interview 87 at 6; Interview 88 at 4 .

898 Interview 25 at 8: "You know, there are political statements and there are technical statements. The political statement is that we don't have Indigenous people in Tanzania but we know there are. But the government does not recognize those. We do work through our pastoralist program with those people. Particularly the pastoralists and agro-pastoralists. Essentially on land rights. We know that given the demand on land, given the tendency of land grabs by foreign companies or whatever, given that in many areas you don't have the land use plans, pastoralists are having problems. Mobility for this group of people is essential. For us, mobility is a statement of their livelihood. We are helping them to be able to advocate for that. We also advocate for the pastoralist policy. [...] But we are not saying that we do really work with Indigenous communities. Our impact population is people who are living in rural, underserved areas. Women and girls. It is mainly those who have their lives are effected by environmental restrictions." 
work toward the recognition and protection of the rights of local communities to access, govern, or benefit from their forests and lands. While the CCB Standards do include a criterion that indeed requires a project to be implemented on land that is owned or managed by communities, this is an optional criterion on exceptional community benefits (GL2). In sum, while the CCB Standards create a clear market incentive to respect the participatory rights of local communities, to share benefits with them, and to not violate their forest and land tenure rights, the extent to which they actually incentivize the promotion of community forest rights and institutions is more limited. These key differences in market incentives may help explain why cost-benefit adoption played an important role in the conveyance of legal norms relating to participation and benefit-sharing, but was not operative with respect to the promotion of forest, land, and tenure rights.

In addition, the divergent manner in which REDD+ projects have addressed forest and land rights across these two countries has much to do with the costs and benefits of community forestry in comparison with other types of project interventions. ${ }^{89}$ Unlike participatory rights and benefit-sharing arrangements that can generally be implemented in one form or another across a range of project designs and contexts, the extent to which the proponents of a REDD+ project may be able and willing to promote the recognition and protection of forest, land tenure, and resource rights can be expected to depend on the legal, political, social, and economic realities that shape the prospects for community forest governance in a particular context.

There are significant differences in the array of opportunities and challenges offered for community forestry rights and institutions in Indonesia and Tanzania. For one, the legal process for clarifying and resolving land and forest tenure issues in Indonesia is complex, cumbersome, and ineffective ${ }^{900}$ and is moreover pitted against powerful economic interests that stand to lose from the recognition and protection of community forest and resource rights. ${ }^{901}$ Although it is beset by its own complications, the process for securing community rights to forest lands and resources is nonetheless much more straightforward in Tanzania under the

899 Although my explanation focuses here on the cost-benefit commitment that underlies the construction of legal norms in the design of a REDD+ project, this process is of course embedded in existing norms that shape the appropriateness of different interventions. One could thus argue that the selection of interventions by conservation NGOs in Tanzania was also influenced by their shared understandings concerning the importance of community forestry in conservation efforts.

900 I am referring here to the existing formal legal mechanisms that exist for granting communities the power to govern and manage their forests. The legal challenges associated with the recognition and protection of adat rights to forests is even greater. See Section 3.1. Interview 85 at 5; Sunderlin et al., supra note 47 at 44,46 , and $48-49$. 
Forest Act. And while providing communities with greater rights over their forests may conflict with the material interests of district officials, the expansion of community management of forests does not currently threaten any influential economic or political lobby groups in Tanzania. ${ }^{902}$ For another, while strengthening community tenure or implementing community-based forest management makes eminent sense in a least-developed country like Tanzania where most drivers of deforestation are local in nature (such as local demand for energy and food), ${ }^{903}$ it does not necessarily amount to an effective strategy for addressing the large-scale drivers of deforestation in a middle-income country like Indonesia (such as palm oil plantations, logging, or mining). ${ }^{904}$

All told, I argue that the key divergences in the promotion of community tenure and forest rights across project-based REDD+ activities in Indonesia and Tanzania can thus be explained by the rational manner in which project developers designed their projects in the light of market incentives provided through the CCB Standards and the particular challenges and opportunities offered for community forestry versus other types of interventions in each country. In Tanzania, the legal process set out in the Forest Act and the local nature of drivers of deforestation meant that the promotion of community forest rights and tenure appeared to be a viable solution for reducing carbon emissions through a REDD + project. Conversely, the very different legal and political economic conditions that characterize forest governance in Indonesia have made community forestry a much less effective basis for the design of a REDD+ project. $^{905}$

\subsection{THE FUTURE OF INDIGENOUS AND COMMUNITY RIGHTS IN THE TRANSNATIONAL MARKET FOR REDD+}

This chapter has shown how legal norms relating to the rights of Indigenous Peoples and local communities have been conveyed and constructed across local sites of law for project-based REDD+ activities. I uncovered broad trends in the recognition and protection of rights in the context of projectbased REDD+ activities in Indonesia and Tanzania. By and large, I found that most REDD+ projects had enacted or implemented legal norms

902 See Section 4.1. 903 Dokken et al., supra note 876 at $247-248$.

904 Resosudarmo et al., supra note 838 at 78-80.

905 See WWF, "Fact Sheet: WWF Forest and Climate Programme, REDD+ Inspiring Practices: Building REDD= Readiness through participatory land use mapping and planning in Indonesia” (2014), available at: http://dzouvy59podg6k.cloudfront.net/downloads/final_ip_in do_land_map_english_web.pdf (accessed 17 June, 2016) at 5 (noting that the legal framework in Indonesia "offers inadequate recognition or protection for customary rights and traditional land uses limits the effectiveness of participatory land use mapping and planning.") 
relating to participation and benefit-sharing in response to market incentives (cost-benefit adoption) and broader norms about the instrumental value of participation and empowerment for the success of their projects (élite internalization). I also found that while most REDD+ projects in Tanzania have sought to enhance the rights of communities to access, manage, and benefit from their forests, only half of projects in Indonesia had done so. This divergence in outcomes results from the particular set of challenges and benefits arising from existing laws for the recognition and implementation of community and tenure forest rights and the political economy of forest governance in both countries. In general, I emphasized the key role that the mechanism of cost-benefit commitment tends to play in the design of REDD+ projects on the ground.

These findings speak to both the potential and limitations of project-based REDD+ activities for supporting the recognition and protection of the rights of Indigenous Peoples and local communities in developing countries. On the one hand, my analysis of the design and implementation of REDD+ projects in Indonesia and Tanzania shows that project developers have indeed accorded significant attention to the participatory and substantive rights of local communities. This is consistent with emerging evidence on the ways in which REDD+ projects have sought to engage and empower communities around the world. ${ }^{906}$ On the other hand, my analysis also reveals the enduring relevance of national laws as well as the critical role played by the underlying political economy of forestry in shaping the willingness and capacity of the proponents of REDD+ projects to promote the forest, land tenure, and resource rights of Indigenous Peoples and local communities. This, too, is consistent with existing research on the limited ability of project-based REDD+ activities to address and resolve long-standing tenure issues that originate in national legal systems and challenges in developing countries. ${ }^{907}$

Notwithstanding a divergence in the extent to which REDD+ projects have promoted community forest rights and institutions, it is striking that the overwhelming majority of the thirty-eight REDD+ projects have had some positive impacts on the rights of local communities and that very few appear to have engendered the sort of human rights violations that were feared by scholars and practitioners in the earlier stages of the global emergence of REDD+. This raises the critical question of whether and how REDD+ project-based activities are likely to influence the rights of Indigenous Peoples and local communities in ways that go beyond their immediate impacts at the local

906 See Lawlor et al., supra note 12; Sunderlin et al., supra note 47.

907 Sunderlin et al., supra note 47. 
level. I argue that there are three pathways through which the domain of projectbased REDD+ may affect the prospects for the rights of Indigenous Peoples and local communities in the long-term.

The first pathway through which REDD+ projects may affect the recognition and protection of Indigenous and community rights in the long-term has to do with the extent to which these projects may or may not empower Indigenous Peoples and local communities. My review of thirty-eight REDD+ projects in Indonesia and Tanzania as well as Lawlor et al.,'s global survey of community participation and benefits in forty-one REDD+ projects suggests that most projects have sought to build the capacity of local communities to sustainably use and manage their forest resources and that many projects have sought to strengthen the forest, land tenure, and resource rights of local communities in doing so. ${ }^{908}$ Likewise, a review of NICFI's support of civil society also evinces that many recipients of REDD+ funds have seen REDD+ as an opportunity to focus on community development and livelihoods or to tackle related issues in forest governance and policy. ${ }^{909}$ If a REDD+ project has meaningfully built the capacity of Indigenous Peoples and local communities to understand and exercise their participatory and substantive rights in relation to forests and their resources, one could hypothesize that these groups may be more likely to mobilize for the recognition and protection of their rights in the future. REDD+ projects may also, inadvertently, provide an opportunity for local populations to mobilize around the protection of their land and resource rights. ${ }^{910}$ The key to this sort of empowerment is what socio-legal scholars call "rights consciousness" - the understanding that actors may develop of their identities and their relations with others on the basis of rights..$^{911}$ Such consciousness is critical as it provides individuals with additional motivations to join interest groups and advocate for their rights ${ }^{912}$, and provides interest groups with

See Sections 5.3 and 5.4 and Lawlor et al., supra note 12 at 304-311. An industry survey from 2016 uncovered that a significant share of forest carbon projects had built the capacity of local populations, shared and generated benefits with them, and resulted in the clarification of land tenure: Allie Goldstein, "Not So Niche: Co-benefits at the Intersection of Forest Carbon and Sustainable Development" (Forest Trends, March 2016), available at: www.forest-trends.org/ documents/files/doc_5153.pdf.

909 NORAD, supra note 673 at $22-23$ and $34-36$.

910 For instance, two REDD+ projects in Tanzania initially generated resistance among local communities. These communities were provided with independent legal advice, negotiated with the proponents of REDD+ projects, and succeeded in having the terms of the proposed contracts altered. See Mäkelä et al., supra note 859 at 20.

$9^{11}$ Michael McCann, Rights at Work: Pay Equity Reform and the Politics of Legal Mobilization (Chicago, Il.: University of Chicago Press, 1994) at 5-9.

$9^{12}$ Michael McCann, "Law and Social Movements: Contemporary Perspectives" (2006) 2:1 Annual Review of Law and Social Science 17 at 25. See also Francesca Polletta, "The 
powerful symbols with which they may pressure authorities in a site of law. ${ }^{913}$ On the other hand, if a REDD+ project has not managed to alter the way in which Indigenous Peoples and local communities see themselves or understand their relations with other actors, the empowerment of local populations may be circumscribed and short-lived.

The second pathway has to do with the broader take-up and effectiveness of the CCB Standards among the public and private actors developing REDD+ projects. Since their emergence in 2005, the CCB Standards have become the dominant scheme for certifying that a REDD+ project has achieved multiple social and environmental benefits beyond carbon sequestration (with 71 percent of REDD+ projects certified through VCS also employing CCB in 2013). ${ }^{914}$ The widespread adoption of the CCB Standards for REDD+ projects is due, in large part, to the current structure of the demand for REDD+ credits on the voluntary carbon market. ${ }^{915}$ The low price of certified emissions reductions on voluntary carbon markets ${ }^{916}$ has significantly reduced interest among private actors in pursuing REDD+ projects for profit-related motivations alone. ${ }^{917}$ In addition, the main motivation for purchasing REDD+ credits on the voluntary carbon market has been corporate social responsibility, and this has generated demand for REDD+ credits that have been certified as providing significant social and environmental benefits. ${ }^{918}$ Finally, a significant share of the start-up funding for REDD+ projects has come from development aid, and this has meant that many REDD+ projects have

Structural Context of Novel Rights Claims: Southern Civil Rights Organizing, 1961-1966" (2000) 34:2 Law \& Society Review 367 at 401.

Goodman \& Jinks, supra note 72 at 144-150.

Peters-Stanley et al., supra note 209 at 58 .

It is beyond the scope of this chapter to explain, in detail, why the CCB Standards have emerged as the dominant multiple-benefit certification scheme for REDD+ projects. For my purposes, I am primarily interested in considering why the use of multiple benefit schemes like the CCB has become so prevalent, as opposed to explaining why the CCB itself has emerged as the dominant standard in competition with similar schemes such as Plan Vivo, the Gold Standard, or Social Carbon. That said, it is worth mentioning that other important factors that may explain the widespread adoption of the CCB Standards might include its early entry in the market for certifying land-based carbon sequestration projects, the role of five of the largest conservation NGOs in its creation, the deliberative and inclusive process through which it has developed its standards, and the streamlined process that it has established with the VCS for dual certification.

In 2013, the certification emissions reductions issued through the validation and verification of projects using the VCS AFOLU methodology yielded an average price of 4.1 US dollars per ton of carbon. Peters-Stanley et al., supra note 209 at 57.

Interview 34 at 1-2; Interview 47 at 7 ; Interview 73 at 6; Interview 77 at 3; Interview 80 at 1.

Peters-Stanley et al., supra note 209 at 50; Hamrick et al., supra note 242 at 17; Goldstein, supra note 908 at 19-20. 
had a pro-poor bias and sought to support and empower forest-dependent communities undertaking or committed to sustainable forest management practices. ${ }^{919}$

As the leading survey of the forest carbon market suggests, dual certification under the VCS and another multiple-benefit certification scheme like the CCB Standards has become an industry practice for REDD+ projects. ${ }^{920}$ While the take-up of multi-benefit schemes like the CCB Standards has been primarily driven by the structure of the voluntary carbon market, their effectiveness will ultimately depend on their emergence as legitimate and authoritative sites of law for REDD+ projects. ${ }^{921}$ Can the CCBA and similar programs achieve and maintain standing as sites of law for project-based REDD+ activities and continue to protect Indigenous and community rights, even if the price of carbon increases in the future? On the one hand, it is entirely possible that a future increase in the price of carbon could attract new project developers and buyers. Because these actors would not have participated in the institutionalization of these socially and environmentally responsible certification schemes and practices, they might develop or support REDD+ projects that would prioritize carbon sequestration to the detriment of the rights of local communities and Indigenous Peoples. On the other hand, there is emerging evidence that norms concerning the importance of generating social benefits are beginning to take hold in the voluntary carbon market, even for projects that are not seeking certification under the CCBA and similar schemes. If the use of a scheme like the CCB Standards is seen as critical to the very design and implementation of a REDD+ project, this might ensure its enduring influence in the voluntary carbon market. ${ }^{922}$

The third pathway through which project-based REDD+ activities may exert broader influence pertains to their indirect effects on the adoption of

Seymour \& Angelsen, supra note 15 at 320; Angelsen \& McNeill, supra note 4 at 43 . This is certainly the case for the REDD+ projects that I analyzed in Tanzania (which were all funded by NORAD) and to a lesser extent in Indonesia.

920 Peters-Stanley et al., supra note 209 at 16.

921 See generally Bernstein \& Cashore, supra note 93 (describing how nongovernmental certification programs can transition from influencing behavior through the provision of market incentives to steering behavior as a legitimate form of authority).

922 See Goldstein, supra note 908 at 26 ("even without strong demand signals, project developers see several benefits to measuring and verifying co-benefits") and Peters-Stanley et al., supra note 209 at 16 ("More than an added bonus, these 'co-benefits' are increasingly becoming a baseline expectation. This is especially true for REDD projects, since co-benefits such as local jobs, alternative income streams, and community trainings are exactly the project activities that will successfully reduce deforestation.") 
REDD+ policies by governments at the national or international levels. ${ }^{923}$ Many scholars have argued that REDD+ projects may generate "lessons for national policies by pointing to the most critical institutional and legal reforms that will be needed to implement REDD+ at the local level."924 These lessons are not simply valuable within the context of a country's jurisdictional REDD+ readiness efforts, but may also be conveyed widely to inform the efforts of other developing countries as well as the design of multilateral and bilateral initiatives that govern jurisdictional REDD+ activities. ${ }^{925}$ All the same, a number of factors might limit the potential of REDD+ projects to generate and disseminate lessons that may be of value for jurisdictional REDD+ policy-making. Many REDD+ projects "are simply old wine in new REDD+ wineskins: existing projects or approaches that have been rebranded as 'REDD+' to attract new finance." ${ }^{26}$ Such projects are of limited utility to policy-makers "because their results may not scale up (precisely because they have picked the 'low-hanging fruit,' i.e., the lowest cost and least controversial projects) and because they may restrict access to information about the site selection process and the early phases of project development (due to concerns over moral hazard, competitors and creating unrealistic expectations)."927 Most importantly, there is considerable variation in the ability and commitment of project proponents to effectively share lessons with other stakeholders, ${ }^{928}$ and policy-makers may simply not be receptive to the lessons and inputs of project

923 Laura Bozzi et al., "The role of climate private voluntary programs affecting forests: Assessing their direct and intersecting effects" in Business and Climate Policy: The Potentials and Pitfalls of Private Voluntary Programs (Tokyo, Japan, United Nations University Press, 2012) $113^{-142}$ at $134-136$.

924 Seymour \& Angelsen, supra note 15 at 297.

925 Jagger et al., supra note 253 at $281-282$ (arguing that "REDD+ is a unique opportunity to share the lessons we learn, because of the global distribution and relatively coordinated timing of projects, significant allocation of financial resources, and clear objectives and explicit mandate set by international negotiators.") The global significance of REDD+ projects also derives from the fact that most such activities are carried out through partnerships involving domestic governmental actors, bilateral aid agencies, local communities and NGOs, international NGOs, international organizations, and private sector actors, thereby enhancing opportunities for knowledge transfer across sites and levels of law (Sills et al., supra note 185 at $276-277$ ).

926 Seymour \& Angelsen, supra note 15 at $297 . \quad 927$ Sills et al., supra note 186 at 269.

928 See NORAD, supra note 673 at 49 ("Some projects, particularly the research projects and several of the large INGOs, have a central focus on identifying and communicating lessons learned, while other projects appear to predominantly communicate lessons learned internally and amongst partners.") and 55 ("Within the INGOs, information flows well up to HQ level and also from HQ down to field level. In some cases, the cross flow of information is less efficient and there is only limited evidence of cross-learning.") 
developers. ${ }^{929}$ This is illustrated in many different ways by my case study of the development of the National REDD+ Strategy in Tanzania, in which the proponents of REDD+ pilot projects had little influence on several aspects of the policies adopted for jurisdictional REDD+, despite their participation in and engagement with the National REDD+ Taskforce. ${ }^{930}$ Finally, given that the construction and conveyance of legal norms in the transnational legal process for REDD+ is shaped by the competing ideas and interests of actors as well as the resilience of existing endogenous norms, there is no reason to believe that the "lessons" generated by REDD+ projects may simply and straightforwardly be accepted and adopted by actors in other sites of law. ${ }^{931}$

929 See Interview 54 at 7 (describing the perspective held by a UN-REDD staff member regarding project-based REDD+ activities: "REDD projects aren't REDD. REDD is a national process under the UNFCCC. We are the ones developing REDD. What you are doing is something else of no interest."); Interview 82 at 9 (describing the fragmentation in the landscape of REDD+ initiatives and activities: "we saw two worlds - the project world and the national discussions on REDD. And under the UNFCCC, everything was focused very much at the national level. The project world was obviously project focused. And a massive gap in terms of how these two were ever going to come together.") See Sections 4.3 and 4.4.

931 See, in relation to the obstacles that stand in the way of the transfer of policy ideas: Diane Stone, "Transfer and translation of policy" (2012) 33:6 Policy Studies 1. 


\section{Comparing Rights and REDD+ in Indonesia and Tanzania}

In Chapters 3, 4, and 5, I traced the conveyance and construction of the rights of Indigenous Peoples and local communities through both jurisdictional and project-based REDD+ activities in Indonesia and Tanzania. Although I did not select these two countries on the basis of variations in initial conditions or eventual outcomes relevant to the implementation of REDD+ or the recognition and protection of rights, a number of lessons can nonetheless be drawn from a comparison of experiences across sites and levels of law in these two countries. In what follows, I discuss findings that relate to rights in the context of the pursuit of jurisdictional REDD+ activities at the national level, before turning to the development and implementation of project-based REDD+ activities at the local level. I conclude with a global comparison of the intersections between rights and various REDD+ activities in these two countries.

\subsection{RIGHTS AND JURISDICTIONAL REDD+ IN INDONESIA \\ AND TANZANIA}

At the national level, the conveyance and construction of rights in Indonesia and Tanzania followed a roughly similar trajectory in that references to human rights obligations, principles, and issues gradually increased throughout the development of a national strategy or the formulation of a set of social and environmental safeguards for REDD+. In addition, in both countries, the initial conveyance of legal norms triggered a process of construction that generated new hybrid legal norms. ${ }^{932}$ This suggests that the domestic implementation of REDD+ has the potential to provide opportunities for the promotion of the rights of Indigenous Peoples and local communities in

932 See Sections 3.4 and 4.4 . 
developing countries. These two case studies reveal that jurisdictional REDD+ readiness efforts may trigger at least one pathway for the conveyance and construction of Indigenous and community rights in developing countries.

My analysis of the experience in Indonesia suggests that international funding for jurisdictional REDD+ readiness activities provided by Norway and its associated conditions led Indonesian government officials to adopt legal norms relating to the full and effective participation of stakeholders (specifically including "Indigenous Peoples") in the design and implementation of REDD+. Because the material benefits of obtaining funding exceeded the political costs of facilitating the participation of stakeholders, the Indonesian government eventually held a series of multi-stakeholder consultations on the development of a national REDD+ strategy at the national and regional levels. In turn, the pursuit of jurisdictional REDD+ activities created new and unique opportunities for Indonesian NGOs to pressure Indonesian government officials to recognize and protect their rights. This mobilization played a key role in triggering the conveyance of rights to Indonesia's jurisdictional REDD+ readiness efforts. Finally, I argued that by engaging in a process of persuasive argumentation with their domestic and international interlocutors throughout the pursuit of jurisdictional REDD+ activities, Indonesian officials in the National REDD+ Taskforce and Agency developed and internalized new norms about the appropriateness of respecting the rights of Indigenous Peoples and local communities in the context of REDD+. The ultimate outcome of this deliberative process was the construction of a new hybrid legal norm extending rights formally held by Indigenous Peoples under international law to both Indigenous Peoples (conceived of as masyarakat adat - the preferred term of Indigenous activists in Indonesia) and nonIndigenous local communities. ${ }^{933}$

The causal pathway that helps explain the conveyance and construction of rights in the context of the development of Tanzania's policy on social and environmental safeguards is broadly similar to the one I have just described. To begin with, the National REDD+ Taskforce's commitment to developing a policy on social and environmental safeguards for REDD+ was driven by the combined effect of the mechanisms of cost-benefit adoption and mobilization. Indeed, Tanzanian officials committed to developing a set of social and environmental safeguards for REDD+ because this would enable them to eventually access sources of finance for REDD+ as well as respond to one of the main demands expressed by domestic NGOs. Moreover, the use of the REDD+ SES Initiative in the development of a policy on social and 
environmental safeguards fostered the engagement of Tanzanian government officials in a deliberative discourse with other domestic actors and their international interlocutors around the nature and extent of participatory rights in the context of REDD+. This process of persuasive argumentation explained how exogenous legal norms relating to the rights of Indigenous Peoples were eventually translated into new hybrid legal norms benefiting forest-dependent communities and marginalized communities, but not Indigenous Peoples. ${ }^{934}$

One notable difference between these two cases concerns the way in which the policies for jurisdictional REDD+ address the distinctive status and rights of Indigenous Peoples. It is important to recall that the traditional position of both the Indonesian and Tanzanian governments has been to deny the existence of Indigenous Peoples on their territories. ${ }^{935}$ Tanzania's national REDD+ strategy and safeguards do not recognize that the concept of Indigenous Peoples is applicable in its territory and extend Indigenous rights to forest-dependent communities but not to Indigenous Peoples as such. Instead, the development of land and resource rights in Tanzania's National REDD+ Strategy built on existing endogenous legal norms regarding the legitimacy of village governance and the superiority of participatory forest management that excluded Indigenous communities from their purview. What is more, by identifying pastoralism as a driver of deforestation, the strategy envisages policy interventions that may ultimately have negative implications for the rights of Indigenous Peoples. ${ }^{936}$ Conversely, Indonesia's national REDD+ strategy and safeguards incorporate numerous references to the status and rights of Indigenous Peoples ${ }^{937}$ - so much so that Indigenous activists in Indonesia have called on the Indonesian government to implement the national REDD+ strategy and have relied on it in their broader advocacy efforts. ${ }^{938}$

I would offer two possible, complementary explanations for these differing outcomes. In line with existing research on transnational processes of persuasive argumentation, ${ }^{939}$ the experience of Tanzania may simply reveal the enduring resilience of a powerful counter-norm to the effect that all Tanzanians are Indigenous and that the concept of Indigenous Peoples is a concept that applies to pre-colonial communities in the Americas. In the case of the National REDD+ Strategy, this counter-norm prevented the internalization of any exogenous norms relating to the concept and rights of

$934 \quad$ See Section 4.5. $\quad 935 \quad$ See Sections 3.1 and 4.1. $\quad 93^{6} \quad$ See Section 4.4 above.

937 See Section 3.4 above. $\quad 93^{8}$ Wajyudi \& Amir, supra note 543; AMAN et al., supra note 545.

939 Halliday \& Carruthers, supra note 62 at 344-345; Anja Jetschke \& Andrea Liese, "The Power of Human Rights a Decade After: From Euphoria to Contestation” in Risse, Ropp \& Sikkink, supra note 72,26 at 35-41. 
TABLE 6.1. Overview of the treatment of the rights of Indigenous Peoples and forest-dependent communities in the jurisdictional REDD+ policies adopted in Indonesia and Tanzania

\begin{tabular}{|c|c|}
\hline Type of right & Indonesia \\
\hline Participatory Rights & $\begin{array}{l}\text { The National REDD+ Strategy recognizes the status } \\
\text { and participatory rights of Indigenous Peoples and } \\
\text { local communities, including the right to FPIC. It } \\
\text { also sets out a series of detailed principles that should } \\
\text { guide the implementation of FPIC in the context of } \\
\text { jurisdictional REDD+ activities. }\end{array}$ \\
\hline
\end{tabular}

The safeguards policy for REDD+ requires respect for the traditional knowledge, values, and rights of Indigenous Peoples and local communities, including the requirement of FPIC, and the integration of these groups into the design and implementation of REDD+ activities. It also mandates the full and effective participation of all stakeholders at all stages in the design, implementation, and evaluation of REDD+ activities, with a special focus on women and marginalized communities.

Tanzania

The National REDD+ Strategy intends to foster the "equal and active participation of stakeholders in the implementation of REDD+ schemes" (including local communities, but not Indigenous Peoples). It focuses on the implementation of the Forest Act and does not integrate the right to FPIC.

The safeguards policy for REDD+ requires that "[k]ey stakeholders participate fully and effectively in designing, planning, implementing, monitoring and evaluating REDD+ initiatives and MRV process." It also provides that "REDD+ initiatives recognize, respect and utilize existing complaint and dispute resolution mechanism at both local and national levels for REDD+ related claims." Finally, it mandates that a REDD+ initiative "promotes and respects the right to free prior and informed consent (FPIC) of forest dependent communities and marginalized groups for any REDD+ activities that might affect their rights to land and natural resources." 
Substantive Rights importance of respecting statutory and customary land and resource rights, the role of communitybased forest management, and the need for land tenure reform, clarification, and dispute resolution mechanisms. It supports the development of sustainable local economies based on alternative livelihoods and expanded job opportunities. Finally, it recognizes the importance of developing fair, transparent, and accountable systems and mechanism for benefit-sharing.

The safeguards policy for REDD+ provides for the identification, recognition, and protection of the land and resource rights of Indigenous Peoples and local communities and mandates mechanisms to resolve conflicts and addresses grievances in relation to land rights issues in the context of REDD+ activities. It also mandates the equitable, transparent, and participatory sharing of the benefits of REDD+ among all rights holders and relevant stakeholders, based on their rights as well as their contribution to reductions in carbon emissions.
The National REDD+ Strategy envisages scaling up community-based forest management, accelerating participatory land-use planning, and increasing the demarcation and mapping of village lands based on the Forest Act. Finally, it supports improving access to energy alternatives and economic opportunities for forest-dependent communities. On the other hand, the strategy ignores the status and rights of Indigenous Peoples and proposes a number of interventions that could have negative impacts on Indigenous Peoples, most notably in its identification of pastoralism as a driver of deforestation and its commitment to reviewing "livestock policy and strategies to reduce overgrazing and nomadic pastoral practices" and supporting "commercial livestock destocking campaigns."

The safeguards policy for REDD+ requires that REDD+ initiatives "recognize, guarantee and respect forest dependent communities and marginalized groups' rights to land and natural forest resources." The safeguards policy for REDD+ requires "that REDD+ initiatives improve livelihoods and well-being of forest dependent communities especially the marginalized and vulnerable groups." It also provides that the "costs incurred and benefits generated by the REDD+ initiative are shared in a timely, transparent and equitable manner among all relevant stakeholders." 
Indigenous Peoples. In the case of the safeguards policy, this counter-norm led to the construction of a hybrid legal norm providing Indigenous rights to forestdependent communities only. By contrast, Indigenous activists in Indonesia were capable of enhancing the resonance of exogenous Indigenous rights norms because they were able to align them with existing endogenous norms relating to the status and rights of masyarakat adat communities in Indonesia - a tactic that other scholars have uncovered in their work on the translation or vernacularization of international norms. ${ }^{940}$

In addition, this variation may also be the product of key differences in the resources and opportunities open to Indigenous activists in both countries and may thus speak to the scope conditions for the effectiveness of mobilization as a causal mechanism for the conveyance of legal norms. ${ }^{941}$ In accordance with resource mobilization theory, the relative success of Indigenous activists in Indonesia might be explained by their greater access to financial resources, their superior level of organization, their connections with international NGOs and networks, and their ability to build alliances with other domestic environmental and human rights NGOs. ${ }^{94^{2}}$ In comparison, the Indigenous movement in Tanzania is disjointed and fragmented and did not build effective alliances with other domestic or international actors both in general ${ }^{943}$ and in the particular context of Tanzania's REDD+ readiness process. ${ }^{944}$ In addition, a comparison of the political opportunity structure of the jurisdictional REDD+ readiness process in both countries suggests that Indonesia likely provided greater opportunities for domestic mobilization than Tanzania. Indonesian NGOs were able to take advantage of the openings provided by the consultative and inclusive manner in which the REDD+ strategy and safeguards were developed, the reformist officials and experts that were appointed to the National REDD+ Taskforce, and the relative marginalization of the Ministry of Forestry as a policy actor. ${ }^{945}$ Although Tanzanian Indigenous activists were also given an unprecedented opportunity to participate in the policy-making process around REDD+ by being invited to join a working group of the National REDD+ Taskforce, they were generally excluded from regional consultations on the development of a national REDD+ strategy and were unable to exert any influence on decision-making regarding REDD+. In this context, the fact that other Tanzanian domestic International Politics (Ithaca, NY: Cornell University Press, 1998) at 6o-72; Merry, supra note 120 at 44 .

941

942

945

See generally Edwards \& Gillham, supra note 108; McAdam, supra note 108.

See Section 3.5. $\quad 943$ See Section 4.1. 944 See Sections 4.2, 4.3, and 4.4.

See Section 4.5. 
NGOs were advocating for the recognition and protection of the rights of forest-dependent communities, but not those of Indigenous Peoples, only reinforced the latter's marginalization in the jurisdictional REDD+ policymaking process. ${ }^{946}$

\subsection{RIGHTS AND PROJECT-BASED REDD+ IN INDONESIA AND TANZANIA}

A comparison of my findings relating to the conveyance and construction of rights in the context of the development and implementation of REDD+ projects in Indonesia and Tanzania also yields interesting lessons. As discussed in Chapter 5, my analysis of the design and early outcomes of REDD+ projects in Indonesia and Tanzania shows that while most REDD+ projects have enacted and implemented legal norms relating to participatory rights and benefit-sharing, there is considerable variation across both countries in terms of the recognition and protection of forest, land tenure, and resource rights.

While it was not feasible for me to explain why and how these rights were conveyed and constructed across every single one of the thirty-eight REDD+ projects in my data set, I nonetheless formulated probable explanations that could account for broad trends in the recognition and protection of rights across these two countries. To begin with, I posited that the conveyance and construction of legal norms relating to participatory rights and benefit-sharing in the design and implementation of a majority of REDD+ projects in Indonesia and Tanzania could be primarily explained by the causal mechanisms of cost-benefit adoption, élite internalization, and cost-benefit commitment. In the first instance, given that most REDD+ projects were established with the aim of eventually generating carbon credits that could be sold on the voluntary carbon market through dual certification under the VCS and CCB, the requirements set by the CCB Standards appear to have been an important instrumental motivation for the proponents of REDD+ projects in Indonesia to enact and implement exogenous legal norms relating to participation and benefit-sharing. In the second instance, the proponents of REDD+ projects also enacted and implemented these legal norms because they had internalized that doing so was integral to the very success of their projects. As a result of a broader process of persuasive argumentation that has reshaped the field of conservation over the last two decades, many project developers understood that ensuring the participation of communities and sharing benefits with them was critical for guaranteeing their collaboration as well as ensuring the 
TABLE 6.2. Overview of the treatment of the rights of Indigenous Peoples and forestdependent communities in the design and implementation of REDD+ projects in Indonesia and Tanzania

\begin{tabular}{|c|c|c|}
\hline Type of right & Indonesia & Tanzania \\
\hline Participatory Rights & $\begin{array}{l}86 \% \text { of REDD+ projects } \\
\text { respected the } \\
\text { participatory rights of } \\
\text { Indigenous Peoples and } \\
\text { local communities. }\end{array}$ & $\begin{array}{l}\text { All but one REDD+ project } \\
\text { respected the } \\
\text { participatory rights of } \\
\text { Indigenous Peoples and } \\
\text { local communities. }\end{array}$ \\
\hline Substantive Rights & $\begin{array}{l}\text { Half of REDD+ projects } \\
\text { have sought to empower } \\
\text { Indigenous Peoples and } \\
\text { local communities } \\
\text { through capacity- } \\
\text { building, livelihood } \\
\text { programs, and benefit- } \\
\text { sharing. Half of REDD+ } \\
\text { projects have also } \\
\text { contributed to } \\
\text { strengthening the } \\
\text { community land, tenure, } \\
\text { and resources rights of } \\
\text { Indigenous Peoples and } \\
\text { local communities. }\end{array}$ & $\begin{array}{l}\text { All of the projects provided } \\
\text { communities with } \\
\text { alternative livelihoods and } \\
\text { capacity-building, with } \\
\text { few projects being able to } \\
\text { successfully test benefit- } \\
\text { sharing mechanisms in } \\
\text { the form of payments to } \\
\text { communities. Seven of } \\
\text { the ten projects have led } \\
\text { to the clarification or } \\
\text { strengthening of the land } \\
\text { and tenure rights and } \\
\text { capabilities of local } \\
\text { communities. }\end{array}$ \\
\hline
\end{tabular}

sustainability of REDD+ projects in the long-term. In the third instance, I argued that the conveyance of legal norms relating to participation and benefit-sharing ultimately triggered a process of construction in which these legal norms were adjusted to the particular context in which REDD+ projects were designed and implemented through the causal mechanisms of costbenefit commitment. Indeed, whether and how to engage and empower local communities in the design and implementation of a REDD+ project can be expected to depend on numerous factors and the design of many REDD+ projects may be seen as resulting from the construction of hybrid legal norms in which exogenous legal norms are rationally calibrated and adjusted in order to craft redesigned solutions to achieve the objective of addressing the local drivers of deforestation and reducing carbon emissions from forest-based sources. ${ }^{947}$ 
These three causal mechanisms also help explain why REDD+ projects in Indonesia and Tanzania have accorded very little attention to the distinctive status and rights of Indigenous Peoples. To begin with, the fact that the CCB Standards extend similar rights and protections to both Indigenous Peoples and local communities eliminated any market incentive for project developers to distinguish between these two categories in the design and implementation of REDD+ projects. Moreover, the shared understanding that many conservation practitioners held regarding the importance of engaging with and empowering local communities in REDD+ was primarily based on whether their collaboration was essential to the success of a project, whether or not they held the particular status of Indigenous Peoples. Finally, the distinction between Indigenous Peoples and local communities was not particularly relevant to the local context in which many REDD+ projects were implemented, especially in Tanzania, where none of the REDD+ projects were implemented on or near lands occupied or used by Indigenous Peoples. ${ }^{948}$

Although most REDD+ projects have enacted or implemented legal norms relating to participation and benefit-sharing in broadly similar proportions in Indonesia and Tanzania, a key difference remains with respect to their implications for strengthening forest, land tenure, and resource rights. Most REDD+ projects in Tanzania sought to strengthen the forest and tenure rights of local communities and many succeeded in enhancing the land tenure of forestdependent communities. By contrast, only half of REDD+ projects did so or sought to do so in Indonesia. I explained this divergence on the basis of two factors. First, while the CCB Standards create a clear market incentive to respect the participatory rights of local communities, to share benefits with them, and to not violate their forest and land tenure rights, the extent to which they actually incentivize the promotion of community forest rights and institutions is limited. Second, the divergent manner in which the proponents of REDD+ projects have addressed forest and land rights across these two countries has probably much to do with the costs and benefits of community forestry in comparison with other types of project interventions. Indeed, while the legal process for clarifying and resolving land and forest tenure issues in Indonesia is complex, cumbersome, and ineffective and is moreover pitted against powerful economic interests that stand to lose from the recognition and protection of community forest and resource rights, the process for securing community rights to forest lands and resources in Tanzania is much more straightforward and does not threaten any influential economic or political interests. And while strengthening community tenure or implementing 
community-based forest management makes eminent sense in a leastdeveloped country like Tanzania where most drivers of deforestation are local in nature (such as local demand for energy and food), it does not necessarily amount to an effective strategy for addressing the large-scale drivers of deforestation in a middle-income country like Indonesia (such as palm oil plantations, logging, or mining). ${ }^{949}$

In sum, I argue that the key divergences in the promotion of community forest, land tenure, and resource rights across project-based REDD+ activities in Indonesia and Tanzania can be best explained by the rational manner in which project developers designed their projects in light of endogenous legal norms and the particular challenges and opportunities offered for community forestry versus other types of interventions. In Tanzania, the legal process set out in the Forest Act and the local nature of drivers of deforestation meant that the promotion of community forest rights and tenure appeared to be an optimal solution for reducing carbon emissions through a REDD+ project. Conversely, the very different legal and political economic conditions that characterize forest governance in Indonesia would make community forestry a much less appealing option for the design of a REDD+ project.

\subsection{RIGHTS AND REDD+ AT MULTIPLE LEVELS IN INDONESIA AND TANZANIA}

An analysis of the implications of REDD+ for the recognition and protection of the rights of Indigenous Peoples and local communities in Indonesia and Tanzania reveals the potential for the transnational legal process for REDD+ to yield convergent as well as divergent outcomes across levels of law within a particular country. On the one hand, the conveyance and construction of rights in the context of jurisdictional and project-based REDD+ activities in Tanzania had largely convergent effects. At the national level, the core strategies and activities envisaged in Tanzania's National REDD+ Strategy were informed by, and seek to implement, the provisions on CBFM and JFM articulated in the Forest Act. Likewise, the REDD+ pilot projects pursued by nongovernmental actors provided the means and impetus to implement the same provisions at the local level. And while forest-dependent communities have largely gained from the pursuit of jurisdictional and project-based REDD+ activities in Tanzania, Indigenous Peoples have been largely ignored by these same activities and have not benefited from an opportunity to use 
REDD+ as a vehicle to gain greater recognition for their status, role, and rights in the governance of forests in Tanzania.

On the other hand, my research suggests that various forms of REDD+ have had divergent implications for the rights of Indigenous Peoples and local communities in Indonesia. To be sure, Indigenous Peoples have made important gains from the pursuit of jurisdictional REDD+ activities, especially because their distinctive status and rights have been recognized in both Indonesia's National REDD+ Strategy and its policy on social and environmental safeguards. In addition, Indigenous activists and communities now have an opportunity to advocate for the recognition of their substantive rights to forests, land tenure, and resources as a result of these new policy commitments and the creation of new mechanisms for the clarification of forest tenure and the resolution of land disputes. On the other hand, Indigenous Peoples have made few gains from the development and implementation of REDD+ projects at the local level. Not only have most projects generally failed to increase the land tenure security of Indigenous Peoples in Indonesia, but the few projects that have done so have sought to implement licenses for community forestry and ecosystem restoration as opposed to pressing for the recognition of the customary forest and land rights of adat communities.

Ultimately, the broader lesson that can be drawn from a comparison of my findings on the intersections between REDD+ and rights in Indonesia and Tanzania concerns the persistent role that the path-dependence of national sites of law has played in shaping or limiting the influence of the transnational legal process for REDD+. My study of jurisdictional REDD+ readiness activities in Tanzania revealed how an existing endogenous norm (to the effect that there are no Indigenous Peoples in Tanzania) hindered the transplantation of exogenous legal norms relating to Indigenous rights and led to the construction of hybrid legal norms extending these rights to forestdependent communities. To a lesser extent, the recognition of the rights of local communities, alongside those of Indigenous Peoples, in the context of Indonesia's jurisdictional REDD+ policies also revealed the resilience of similar endogenous norms that led to the translation, rather than the transplantation, of Indigenous rights norms. Existing national laws and the political economy of national forest governance were also shown to have exerted influence on the manner in which legal norms were constructed in each country. In Tanzania, the transnational legal process for REDD+ reinforced, and was ultimately shaped by, endogenous legal norms that enabled villages to obtain formal rights to manage and control forests and their resources on village lands. It was also enabled by the perception of community forestry as a cost-effective way of addressing the local drivers of deforestation and the fact 
that this approach did not arouse strong opposition from powerful economic and political interests. Conversely, the complex, ineffective, and uncertain set of laws, policies, and processes for clarifying and resolving land and forest tenure issues in Indonesia significantly limited the ability for project-based REDD+ activities to enhance the protection and recognition of community forest and resource rights. Only time will tell whether these same factors will bedevil the ability for the National REDD+ Agency to implement the May 2013 Constitutional Ruling recognizing the customary forest tenure rights of masyarakat adat. In sum, a cross-level analysis of the relationship between REDD+ and rights in Indonesia and Tanzania reveals the extent to which the ultimate effects of the transnational legal process for REDD+ has the potential to transcend, as well as be shaped by, national law and politics. ${ }^{95^{\circ}}$

950 For similar observations in other contexts involving transnational governance, see Prakash \& Potoski, supra note 80 at 374-375; Bartley, "Transnational Governance as the Layering of Rules: Intersections of Public and Private Standards" (2011) 12:2 Theoretical Inquiries in Law 519 at $524-526$. 


\section{Conclusion \\ REDD+, Rights, and Law in a Transnational Perspective}

In this concluding chapter, I begin by discussing the significance and limitations of my findings regarding the complex relationship between the transnational legal process for REDD+ and the rights of Indigenous Peoples and local communities in developing countries. Next, I identify the questions and implications that my findings raise for scholarship on REDD+ as well as the nature and influence of transnational legal processes. I conclude by addressing the implications of this book for practitioners and activists working to build synergies between the pursuit of REDD+ and the promotion of human rights.

\section{SIGNIFICANT FINDINGS ON REDD+ AND RIGHTS}

The significance of my research on the complex relationship between REDD+ and Indigenous and community rights can be summed up in the following five conclusions. First, the emergence and spread of REDD+ across sites and levels of law has functioned as an opportunity for multiple actors to shape the conveyance and construction of legal norms that recognize and protect the rights of Indigenous Peoples and local communities. My findings suggest that the transmission of legal norms relating to REDD+ has functioned as something of an exogenous shock that has disrupted the traditional patterns of the development and implementation of legal norms relating to the rights of Indigenous Peoples and local communities in several sites of law. In the UNFCCC and Indonesia, the transnational legal process for jurisdictional REDD+ activities led to the recognition of the rights and status of Indigenous Peoples - at least within the domain of REDD+ - for the first time. In Tanzania, efforts to operationalize jurisdictional REDD+ reinforced the rights of forest-dependent communities in the National REDD+ Strategy and expanded these rights to include FPIC in the context of its safeguards 
policy. As far as project-based REDD+ activities are concerned, REDD+ served as a vehicle for NGOs to operationalize and implement their existing commitments to rights-based approaches to conservation and development through the development of the CCB Standards and the REDD+ SES. In turn, the emergence of a voluntary market for REDD+ dominated by development agencies and corporate social responsibility initiatives as well as animated by emerging norms concerning the importance of rights to the effectiveness of REDD+ led many project developers to respect and enhance the participatory and substantive rights of Indigenous Peoples and local communities at the local level.

It is important to stress that the transnational legal process for REDD+ has not been a panacea for Indigenous Peoples and local communities. For one thing, across several sites of law such as the UNFCCC, the World Bank, Indonesia, and Tanzania, I found that the construction of legal norms for REDD+ did not fully reflect the expectations and demands of IPOs and NGOs pushing for greater recognition and protection of Indigenous and community rights. I even uncovered situations in which REDD+ projects had not respected the rights of local communities and concluded, moreover, that the policy processes and outcomes relating to the pursuit of jurisdictional REDD+ activities in Tanzania were not consistent with international standards relating to the protection of the rights of Indigenous Peoples. For another, I found that the influence of the transnational legal process for REDD+ was generally mediated by resilient endogenous norms and politics that prevailed in sites of law. One illustration of the limited effect of REDD+ is Tanzania, where the pursuit of jurisdictional REDD+ readiness activities did not lead government officials to alter their traditional opposition to the concept of Indigenous Peoples. As well, the emergence of REDD+ in the context of the World Bank's creation of the FCPF did not alter the Bank's traditional positions on matters relating to FPIC, where it was defined as an entitlement to be consulted, rather than a right to consent. Most importantly, the exogenous legal norms relating to Indigenous rights that were conveyed to many sites of law ultimately engendered the construction of hybrid legal norms. This is most notably reflected in the ways that the rights of Indigenous Peoples have been translated in the jurisdictional REDD+:activities pursued in Indonesia and Tanzania. In Indonesia, the distinctive status and rights of Indigenous Peoples were recognized alongside those of local communities. In Tanzania, the rights of Indigenous Peoples were interpreted as applying to a broader category known as "forest-dependent communities." In sum, although REDD+ has provided meaningful opportunities for the conveyance and construction of the rights of Indigenous Peoples and local communities 
across various sites of law, these opportunities have not been transcendent, but have instead been shaped by the interplay of exogenous and endogenous factors. ${ }^{951}$

Second, as is summarized in Table C.1, the transnational legal process for REDD+ has offered multiple causal pathways for the conveyance and construction of the rights of Indigenous Peoples and local communities across multiple sites of law. These different pathways unfolded through different sequences and combinations of rationalist and constructivist causal mechanisms and factors. They reveal the critical role that diversity has played in the diffusion of rights in the field of REDD+. Across different sites of law, I found that a multiplicity of public and private actors were committed to building linkages between human rights and REDD+, that they had varying reasons for doing so, and that they deployed a variety of strategies and modes of influence to shape the construction, diffusion, and implementation of rights in the context of REDD+. Moreover, the pluralism of the transnational legal process for REDD+ made it possible for these actors to exert influence, from above and from below, across multiple sites of law that offered different opportunities for the conveyance and construction of rights. This diversity was important not only because it increased the probable activation of the causal mechanisms of conveyance and construction, but also because these mechanisms complemented one another in concurrent or sequential ways. ${ }^{952}$

The third insight offered by this book focuses on the important role played by timing in the conveyance and construction of legal norms relating to the rights of Indigenous Peoples and local communities in the context of REDD +. ${ }^{953}$ There are numerous broader historical developments that have increased the likelihood that the transnational legal process for REDD+ might serve as a vehicle for the promotion of the rights of Indigenous Peoples and forest-dependent communities. To begin with, the treatment of human rights issues by activists and policy-makers in the transnational legal process for REDD+ was influenced by earlier negative experiences with the CDM. The significant human rights issues that came to light in the context of the CDM in the zooos highlighted the importance of advocating for, and developing,

Shaffer, supra note 62 at $236-237$.

On the multiple actors and forms of influence that explain the transnational emergence of human rights, see, Kathryn Sikkink, "Transnational Politics, International Relations Theory, and Human Rights" (1998) 31:3 Political Science and Politics 517.

On the importance of timing and sequencing in processes of change, see Paul Pierson, "Not Just What, but When: Timing and Sequence in Political Processes" (2000) 14 Studies in American Political Development 72. 
TABLE C.1. The pathways for the conveyance and construction of the rights of Indigenous Peoples and local communities provided by the transnational legal process for REDD+ across multiple sites of law

The Pursuit of Jurisdictional The conveyance of exogenous legal norms relating to REDD+ in Indonesia the rights of Indigenous Peoples in the development of Indonesia's National REDD+ Strategy and safeguards policy was driven by a combination of costbenefit commitment and mobilization. This then triggered a process of persuasive argumentation that resulted in the construction of hybrid legal norms extending these rights to both Indigenous Peoples and local communities.

The Pursuit of Jurisdictional Exogenous legal norms relating to the rights of

REDD+ in Tanzania (National REDD+ Strategy)

The Pursuit of Jurisdictional REDD+ in Tanzania (REDD+ Safeguards Policy) Indigenous Peoples were not conveyed in the development of Tanzania's National REDD+ Strategy due to the enduring influence of a powerful endogenous norm (to the effect that all Tanzanians are "Indigenous") as well as the limited resources and opportunities for mobilization open to Indigenous Peoples.

The conveyance of exogenous legal norms relating to the rights of Indigenous Peoples in the development of Tanzania's safeguards policy was driven by a combination of cost-benefit commitment and mobilization. This then triggered a process of persuasive argumentation that resulted in the construction of hybrid legal norms extending these rights to "forest-dependent communities," but not Indigenous Peoples.

The Pursuit of Project-Based The conveyance of legal norms relating to the rights of REDD+ in Indonesia and Tanzania
Indigenous Peoples and local communities in the design and implementation of REDD+ projects in Indonesia and Tanzania was driven by the causal mechanisms of cost-benefit adoption and élite internalization. These legal norms were then calibrated to the legal, political, and economic context in which these REDD+ projects were implemented through the mechanism of cost-benefit commitment. In Tanzania, this generally resulted in the conveyance and construction of legal norms relating to participation, benefit-sharing, and community forestry. In Indonesia, this generally resulted in the conveyance and construction of legal norms relating to participation and benefit-sharing, but not community forestry. 
mechanisms to prevent and mitigate the negative social and environmental impacts associated with climate mitigation initiatives. ${ }^{954}$

In addition, REDD+ has emerged at a time that has been relatively more favorable for the promotion of Indigenous and community rights in environmental governance. The global emergence of the rights of Indigenous Peoples and the adoption of the UN Declaration on the Rights of Indigenous Peoples in 2007 has significantly affected the trajectory of the transnational legal process for REDD+, providing actors with increased awareness of the importance of Indigenous rights and offering an important set of symbols and international commitments that have supported the conveyance of these rights across multiple sites of law. ${ }^{955}$ In addition, the visibility of the rights of local nonIndigenous communities has also increased considerably during this time, as is reflected in the emergence of a rights-based policy agenda in conservation as well as broader trends in the devolution of forest management, tenure, and resource rights in many developing countries, especially in Latin America. ${ }^{956}$ More broadly, the growing importance of human rights to the fields of climate change ${ }^{957}$ and conservation ${ }^{95^{8}}$ has also facilitated the integration of the rights of Indigenous Peoples and local communities in various international and transnational sites of law for REDD+. At the national level, the pursuit of REDD+ in Indonesia and Tanzania followed periods in which these countries had initiated a transition toward decentralization and democratization, which made the very mobilization of endogenous interest groups more likely. ${ }^{959}$

The fourth conclusion that I draw is that the recognition and implementation of the participatory rights of Indigenous Peoples and local communities (such as rights to full and effective participation or to FPIC) appear to have been relatively more effectual than the recognition and implementation of their substantive rights (such as rights to forests, land tenure, resources, or livelihoods). As far as the international and transnational levels are concerned, the UNFCCC

On the human rights issues associated with the CDM, see Savaresi, supra note 11 at 103-104; Roht-Arriaza, supra note 39 at 216-219.

See Sections 2.1, 3.4 and 4.4. See also Wallbott, supra note 265.

William D. Sunderlin, "The Global Forest Tenure Transition: Background, Substance, and Prospects" in Sikor \& Stahl, supra note 11, 19-32.

Rajamani, supra note 291 (discussing the growing relevance of human rights to the international negotiations on climate change).

Sikor \& Stahl, supra note 272 (discussing the emergence of a rights-based agenda in forest governance); Jodoin, supra note 272 (discussing the growing relevance and implications of rights-based approaches to conservation).

See Sections 3.1 and 4.1. See also Beth A. Simmons, "From ratification to compliance: Quantitative evidence on the spiral model" in Risse, Ropp \& Sikkink, supra note 72,43 at 56 (arguing that mobilization is more likely in countries transitioning from autocracy to democracy than in autocratic or democratic countries). 
largely focuses on participatory rights and the CCBA only provides for the promotion of substantive rights in an optional criterion of the CCB Standards. In Indonesia, the National REDD+ Strategy and the safeguards policy recognize both sets of rights, but it remains to be seen whether Indigenous Peoples and local communities will succeed in having their customary forest and land tenure rights recognized and protected in practice. Indeed, the underwhelming results of REDD+ projects in this second regard suggest that this is far from inevitable. Tanzania is perhaps the only context in which I found evidence of the participatory and substantive rights of local communities being recognized and implemented in new and meaningful ways through jurisdictional and project-based REDD+ activities (albeit with the general exclusion of Indigenous Peoples). Of course, it is important to recall that whereas the protection of substantive rights may have been thwarted by the power asymmetries that underlie forest governance in Indonesia, the promotion of community forestry did not threaten powerful economic interests in Tanzania as such.

These broader trends, in which participatory rights have seemingly been given priority over substantive rights and the recognition of rights may ultimately have been subordinated to powerful interests, give a certain level of credence to some of the expectations of scholars regarding the limitations of REDD+ for the protection of human rights. If REDD+ has led to the recognition and implementation of the rights of communities to participate in, and consent to, the design and operationalization of REDD+, while neglecting their substantive rights to access, govern, and benefit from forests or carbon sequestration, this would reflect the preponderant influence of the "uneven playing field" that, many scholars argue, defines the context in which REDD+ has been pursued. ${ }^{960}$ Then again, it is also possible that the recognition of these participatory rights could provide the basis for the development of "rights consciousness" and assist communities in mobilizing for the recognition and protection of their substantive rights in the long-term. ${ }^{961}$ As such, understanding the lasting consequences of REDD+ for Indigenous and community rights will require future research focused on the implementation of policies, programs, and projects on the ground.

Fifth and finally, my book has demonstrated that REDD+ constitutes a paradox for the rights of Indigenous Peoples and local communities in ways that were not expected by scholars and practitioners. The original REDD+ paradox identified by Sandbrook et al., pertained to the fact that the funding

$9^{60}$ Ribot \& Larson, supra note 13. $\quad 9^{61} \quad$ McCann, supra note 912. 
TABLE C.2. The recognition of the distinctive status of Indigenous Peoples and participatory and resources rights in the transnational legal process for REDD+

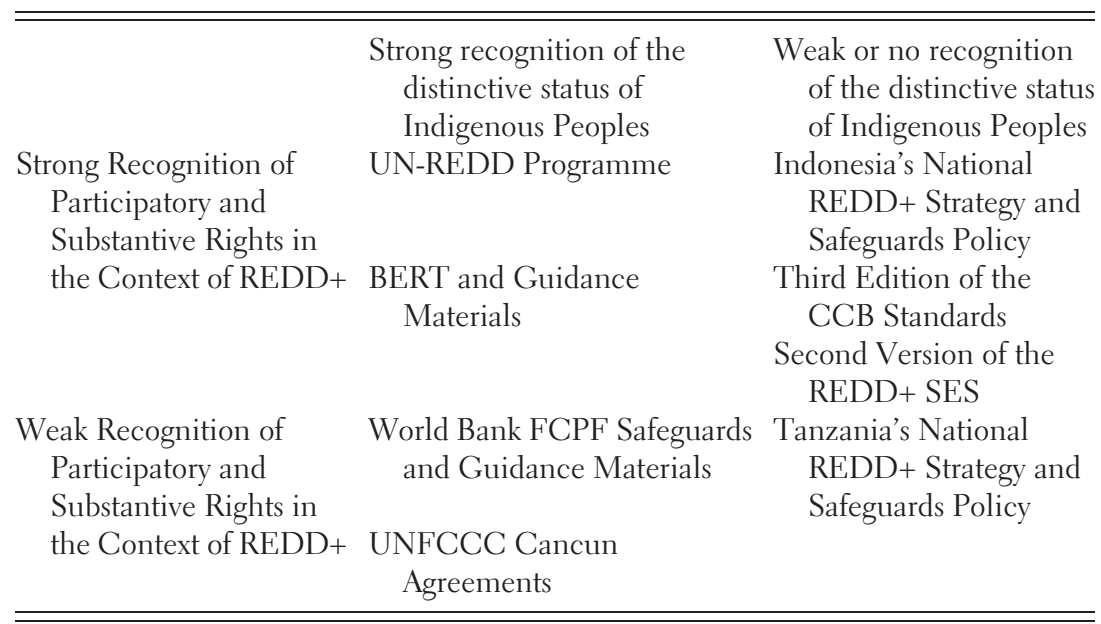

generated through REDD+ had the capacity to generate benefits for forestdependent communities (through the implementation of community forestry and benefit-sharing arrangements), while also posing significant risks for their rights, institutions, and livelihoods (due to corruption, graft, élite capture, and land-grabbing). ${ }^{962}$ While confirming that REDD+ may operate in this Januslike manner, my book also unearths two additional paradoxes.

To begin with, I argue that REDD+ has amounted to a paradox for Indigenous Peoples in particular because there appears to be an underlying tension between the appreciation of their distinctive rights and status and the progressive recognition and expansion of the rights of forest-dependent communities. Indeed, as can be seen from Table C.2, the sites of law in which Indigenous Peoples have succeeded most clearly in having their distinctive status and rights recognized - such as the UNFCCC and the World Bank FCPF - tend to be the sites of law that have accorded the least expansive applications of participatory and substantive rights in the context of REDD+. Conversely, in the sites of law that have offered greater protections for the participatory and substantive rights traditionally held by Indigenous Peoples such as the CCBA, the REDD+ SES, and Indonesia's REDD+ Safeguards these rights have been extended to non-Indigenous local communities as well. What is more, although the development of Tanzania's jurisdictional and project-based REDD+ activities may have led to some gains in terms of the

$9^{62}$ Sandbrook et al., supra note 14 . 
recognition and promotion of rights such as FPIC, these rights were extended to forest-dependent communities to the exclusion of Indigenous Peoples. As such, while REDD+ may have led to the conveyance and construction of community rights across multiple sites of law, it may not have contributed much to the formalization of the collective identities and associated rights of Indigenous Peoples. ${ }^{963}$

The second paradox that I have identified in this book concerns the apparent tension between the effectiveness of REDD+ as an intervention designed to reduce carbon emissions from forest-based sources and its effects on the recognition and protection of human rights. I do not mean to say that there is an inherent trade-off between the broader effectiveness of REDD+ and the protection of human rights. Rather, the insight that I have uncovered is that it is perhaps the very ineffectiveness of REDD+ as a policy instrument that has provided unexpected opportunities for the recognition and protection of the rights of Indigenous Peoples and local communities.

From 2009 to 2014, with the support provided by multiple international actors, government officials in Indonesia and Tanzania carried out a complex program of policy development and capacity-building to support the operationalization of jurisdictional REDD+ in their countries. Due to the size and importance of its forest carbon stocks and the enthusiasm and leadership of President Yudhoyono, the pursuit of REDD+ in Indonesia attracted considerable amounts of funding and attention from multilateral institutions, foreign governments, NGOs, and the private sector. As a result, Indonesia has made considerable progress in establishing a REDD+ Agency and has designed many of the elements required to implement jurisdictional REDD+ at the national level, such as a national strategy, a financial mechanism, an MRV system, and a safeguards policy and information system. ${ }^{964}$ Despite millions of dollars in aid money, a slew of international consultants, and an endless series of meetings, consultations, and workshops, Tanzania had only partially achieved one of the requirements of jurisdictional REDD+ readiness mandated by the Cancun Agreements, namely the development of a National REDD+ Strategy, by September 2014. Tanzania still lacks a REDD+ finance mechanism, a national reference emission level or forest reference level, a system for measuring, reporting, and verifying emissions reductions, and an information system for reporting on the application of social and environmental safeguards. It is not clear that Tanzania will be ready to participate in a

${ }_{963}$ Ronald Niezen, "The Indigenous Claim for Recognition in the International Public Sphere" (2005) 17 Florida Joumal of International Law $5^{83}$.

964 NORAD, supra note 423 at $270-273$. 
global REDD+ mechanism any time soon. ${ }^{965}$ In any case, although Indonesia has reached a more advanced stage than Tanzania in its jurisdictional REDD+ readiness activities, it is striking that the efforts of the last seven years have not actually led to significant reductions of carbon emissions in either country.

Although the challenges of implementing jurisdictional REDD+ activities are now obvious, these limited results are nonetheless disappointing, especially in comparison with the initial enthusiasm that greeted the emergence of REDD + in 2007. On the whole, the complexity of jurisdictional REDD+ and the multiple actors and initiatives that were developed to support the readiness efforts of developing countries appear to have created a unique and unexpected opportunity for the promotion of the rights of Indigenous Peoples and local communities. Two of the core elements of jurisdictional REDD+ readiness - the development of a national strategy and the creation of safeguards information systems - along with the need for technical assistance and the related practice of organizing multi-stakeholder consultative processes have engendered significant openings for local and transnational actors to press for the recognition of human rights in the context of REDD+. In a more indirect fashion, the complexity of designing forest emissions levels, MRV systems, and benefit-sharing schemes required pilot projects as well as lengthy programs of technical assistance that have provided additional time and opportunities for mobilization and persuasive argumentation across sites and levels of law. One can imagine that if the domestic operationalization of REDD+ had simply entailed unconditional payments meant to facilitate the adoption of policies to reduce deforestation by developing countries, this would not have offered as much scope for the conveyance of human rights norms.

The experience of REDD+ projects tells a similar story. A slew of conservation and development NGOs and corporations have spent millions in public and private funding to design and carry out REDD+ projects in Indonesia and Tanzania. While some of these projects have contributed to the sustainable management of forests in significant ways, only two of the thirty-eight REDD+ projects in these two countries have actually obtained certification as a REDD+ project under the VCS and CCB programs ${ }^{966}$ and only two other projects have managed to prepare and submit a project design document for

965 Nordeco \& Acacia, supra note 675 at iii-vi.

966 VCS Project Database, "Rimba Raya Biodiversity Reserve Project," available at: www.vcspro jectdatabase.org/\#/project_details/674 (accessed 13 June 2016); CCBA, "Rimba Raya Biodiversity Reserve REDD Project," available at: www.climate-standards.org/2010/06/08/ri mba-raya-biodiversity-reserve-redd-project/ (accessed 14 June 2016); VCS Project Database, 
validation and verification by third-party auditors under these programs. ${ }^{967}$ It is beyond the scope of this chapter to discuss all of the challenges that REDD+ projects have faced in successfully reducing carbon emissions at the local level and in obtaining dual certification under the VCS and CCB. My research on the development and implementation of REDD+ projects in Indonesia and Tanzania does suggest, however, that the low price of carbon on voluntary carbon markets has been an important barrier to the development of REDD+ projects. At the same time, this appears to have tilted the broader REDD+ market toward standards and projects that aim to empower local communities with respect to their rights and authority over forests. ${ }^{968}$ As such, the very ineffectiveness of the voluntary carbon market has made it possible for REDD+ projects to deliver important social benefits, even as their ability to significantly reduce carbon emissions has not lived up to initial expectations.

This second REDD+ paradox is rather ironic, when judged in light of the concerns initially expressed over the potential risks posed by REDD+ for the rights of Indigenous Peoples and local communities. Indeed, the very same features of REDD+ that many scholars and activists saw as flaws - its technocratic focus on the reduction of carbon emissions and the measurement of carbon stocks, its use of "nonbinding" safeguards, its focus on national-level institution-building, and its reliance on markets - appear to have provided unexpected and meaningful opportunities for its redemption with respect to its effects on rights, though perhaps not in terms of forests or the climate.

\section{LIMITATIONS}

I must acknowledge three important limitations in my study of the transnational legal process for REDD+ and the rights of Indigenous Peoples and local communities. The first limitation has to do with periodization. ${ }^{969}$ As Campbell points out, different time frames may privilege different types of

"Mjumita Community Forest Project (Lindi)," available at: www.vcsprojectdatabase.org/\#/ project_details/1325 (accessed 14 June 2016); CCBA, "MJUMITA Community Forest Project (Lindi)," available at: www.climate-standards.org/2014/05/08/mjumita-community-forest-pro ject-lindi/ (accessed 14 June 2016).

${ }_{967}$ The first is the project by Care International in Tanzania and the second the project by PT Rimba Makmur Utama Katingan in Indonesia. See CCBA, "HIMA (Hifadhi ya Misitu ya Asili ya jamii) REDD+ Program," available at: www.climate-standards.org $/ \% 3$ Fs=HIMA (accessed 14 June 2016); CCBA, "Katingan Peatland Restoration and Conservation Project," available at: www.climate-standards.org/?s=Katingan (accessed 14 June 2016).

${ }_{968}$ See Section 5.5 .

969 Tulia G. Falleti \& Julia F. Lynch, "Context and Causal Mechanisms in Political Analysis" (2009) 42:9 Comparative Political Studies 1143 at 1154-1156. 
explanations, given that causal processes driven by interests tend to unfold in a shorter time frame than those driven by norms. ${ }^{970}$ The period that I studied in my process-tracing runs from the initial emergence in 2005 of the concept that would later become REDD+ in the UNFCCC to the fall of 2014. The latter date was chosen to identify a clear "cut-off time" for what is a constantly evolving and unfolding phenomenon. Indeed, the causal processes associated with the construction and conveyance of the rights of Indigenous Peoples and local communities in the transnational legal process for REDD+ have not yet reached their endpoints and will continue to evolve in the near future. Although my book has traced the conveyance and construction of rights across multiple sites and levels of law for REDD+ during the course of almost a decade, it is still too early to fully assess whether and how these legal norms have been implemented on the ground. While I have offered some hypotheses about the future prospects for the implementation of rights in the context of the jurisdictional REDD+ activities of Indonesia and Tanzania as well as the broader voluntary market for REDD+, additional research will be needed to assess whether and how these rights may affect, in practical terms, the lives and interests of Indigenous Peoples and local communities.

The second limitation has to do with the challenges and constraints of process-tracing as a research method. In their recent book on process-tracing, Beach and Pederson suggest that it is essentially impossible to live up to the standards of causal inference implied by process-tracing. ${ }^{971}$ To be sure, the collection and interpretation of additional evidence could have strengthened the internal validity of my causal claims. Most importantly, while processtracing is feasible as well as appropriate in research designs involving a small number of cases, it not necessarily well-suited to explaining phenomena that involve a large population of cases. ${ }^{972}$ As such, process-tracing only enabled me to make provisional claims about the conveyance and construction of rights across REDD+ projects in Indonesia and Tanzania. ${ }^{973}$ In this second regard, it is clear that a full understanding of how REDD+ projects have affected the recognition and protection of the rights of local populations, especially in terms of their effects on livelihoods, local access to forests and resources, and development of rights consciousness, requires additional and different research methods, including ethnography, household surveys, influence of human rights norms, see Emilie M. Hafner-Burton \& James Ron, "Seeing Double : Human Rights Impact through Qualitative and Quantitative Eyes" (2009) 61:2 World Politics 360.

973 See Section 5.4. 
and rapid rural appraisals. These methods would be especially useful for studying how rights have influenced, if at all, the evolution of community systems of forest and land governance at the local level.

The third limitation has to do with the types of rights that I did not study in this book. In particular, gender-related rights stand out as a missing element in my analysis. Admittedly, the implications of REDD+ on the rights of women were not a particularly important or salient issue across any of the sites of law that I studied, with the exception of the CCB Standards, which do include some legal norms relating to the prohibition of discrimination and the empowerment of women. Yet, given the dynamics of the exclusion and marginalization of women within Indigenous and rural communities in many contexts, there is no reason to think that these rights were not important for ensuring the effective and equitable pursuit of jurisdictional and project-based REDD+ activities. ${ }^{974}$ Other particular types of rights that do not explicitly feature in my analysis include labor rights and rights to freedom from discrimination. ${ }^{975}$ Put differently, this book avoids answering a different, yet equally important, question: why were some human rights norms, notably women's rights, not constructed and conveyed within and through the transnational legal process for REDD+?

\section{FUTURE RESEARCH ON REDD+ AND RIGHTS}

This book suggests four promising lines of inquiry for future scholarship focused on the pursuit of REDD+ and the protection of human rights in developing countries. A first line of inquiry could extend the research in this book by studying the conveyance and construction of rights in other sites of law in the transnational legal process for REDD+. In this book, I have argued that REDD+ provided an opportunity for the conveyance and construction of rights in the jurisdictional REDD+ readiness processes and REDD+ projectbased activities pursued in Indonesia and Tanzania. I have also offered explanations about the particular causal pathways through which this process unfolded and the variations in the recognition and protection of rights that resulted therefrom. While process-tracing is not meant to offer claims that can be generalized to a population of cases, it does offer key lessons about the

974 For research examining gender rights in the context of REDD+, see, H. C. Peach Brown, "Gender, climate change and REDD+ in the Congo Basin forests of Central Africa" (2011) 13 (2) International Forestry Review 163 and Carol J. Pierce Colfer et al., eds., Gender and Forests: Climate Change, Tenure, Value Chains and Emerging Issues (Abingdon, UK: Routledge, 2016).

975 Both of these rights are included in the CCB Standards. 
role of causal mechanisms that can be studied in other cases. Each of the key findings about the construction and conveyance of rights in the transnational legal process for REDD+ in Indonesia and Tanzania provide hypotheses that could be assessed in future research.

Some of the additional sites of law that could be studied through in-depth process-tracing might include international sites of law (such as the UNFCCC, the UN-REDD Programme, and the World Bank FCPF) and transnational sites of law (such as the CCBA, the REDD+ SES, Plan Vivo, and Gold Standard). In particular, I would argue that additional research on the jurisdictional REDD+ readiness process in developing countries such as Brazil, the Democratic Republic of Congo, Mexico, and Vietnam that have moved forward with their efforts to operationalize REDD+ would be especially important. ${ }^{976}$ In addition, as mentioned above, future research on the intersections of REDD+ and rights could also draw on a mix of quantitative and qualitative methods that would allow scholars to explain variations across a larger population of cases. This could enable a rich study of whether and to what extent rights have been recognized and protected in the several hundred REDD+ projects currently being implemented around the world. Finally, additional ethnographic research is required to understand the effects of REDD+ for the rights, livelihoods, systems, and identities of communities at the local level.

A second line of scholarly inquiry could concern the broader structure of the transnational legal process for REDD+. My research confirms that multiple sites, modes, and forms of law have governed the field of REDD+ and that this has led to increasing fragmentation between the legal norms that have been constructed and conveyed for its implementation. Although Bodansky has described REDD+ as an "incipient transnational legal order," 977 I have shown that the transnational legal process for REDD+ has led to variegated outcomes across multiple sites and levels of law. It is certainly the case that REDD+ has led to some convergence in the framing of deforestation and forest degradation as issues of concern for climate change and in the emergence of shared understandings that suggest that carbon sequestration should not be prioritized above other important social issues and considerations. On the other hand, law-making for REDD+ has also led to divergent outcomes

$97^{6}$ Of this set of countries, Brazil and Mexico would be rather interesting because of the limited role that international actors have played in their jurisdictional REDD+ readiness efforts as well as their recognition of the concept and rights of Indigenous Peoples prior to the emergence of REDD+.

977 Daniel Bodansky, "Climate Change: Transnational Legal Order or Disorder?" in Halliday \& Shaffer, supra note 62, 287 at 304 . 
that are reflected not only in the different ways in which sites of law have addressed these social issues (specifically, as I have shown, in terms of their treatment of the rights of Indigenous Peoples and forest-dependent communities), but more broadly in the distinct types and scales of REDD+ activities to which they have applied. As such, additional research is needed to examine the structure of the transnational legal process for REDD+ and the opportunities that exist for greater homogeneity and heterogeneity in the development and implementation of legal norms governing different types of REDD+ activities. For instance, I have identified some of the indirect and intersecting pathways through which the design and application of rights-related standards applicable to REDD+ projects may influence and be influenced by national laws and governance arrangements in the forestry and natural resource sectors in developing countries. These pathways could be further explored in relation to additional sites and levels of law as well as additional aspects of REDD+ (such as the legal norms relating to MRV or the development of property rights over carbon).

A third line of scholarly inquiry pertains to the relationship between the multiple transnational legal processes that have been discussed, implicitly or explicitly, in this book. For one thing, one could argue that the origins of the transnational legal process for REDD+ lie in an earlier transnational legal process for CDM. Future scholarship should examine how and what various actors learned from their experience with the construction and conveyance of legal norms for CDM around the world and how this shaped their approach to REDD+. For another, although I have not discussed it as such, this book offers a partial look at the intersections between at least three transnational legal processes, variously focused on the operationalization of REDD+, the recognition and protection of the rights of Indigenous Peoples, and the recognition and protection of the rights of forest-dependent communities. As such, scholars could initiate future inquiries that would begin with the construction and conveyance of the rights of Indigenous Peoples or those relating to forestdependent communities from the local and national levels to the transnational and international levels and back again, with REDD+ serving as a case study, among others, of the global emergence and spread of the rights of Indigenous Peoples and forest-dependent communities.

One fourth and final set of questions that should be of interest to scholars has to do with the normative implications of the conveyance and construction of rights as they have come into contact with multiple sites of law in the transnational legal process for REDD+. To be sure, the plurality of processes and manifestations of normativity through which the pursuit of REDD+ has fostered the recognition and protection of rights in developing countries raise 
important ethical questions. Is there a danger in having transnational legal processes shape legal norms and practices in ways that are indirect, unexpected, informal, and unmoored from the institutions traditionally associated with the sovereign state or established norms of democratic governance within the nation-state? ${ }^{978}$ Should we be more critical of such processes and more attentive to the power disparities that are implicit in their operation? ${ }^{979}$ Or can the exercise of authority through the nonstate and deterritorialized sites of law discussed in this book be "saved" by their appropriation by social movements ${ }^{90}$ or the practices of global administrative law? ${ }^{981}$ Finally, how should we assess the legitimacy and validity of transnational manifestations of law ${ }^{98}$ and by what normative principles should the pluralism of legal orders be apprehended and reconciled at a global scale? ${ }^{983}$

Another important ethical quandary concerns the different ways that the rights of Indigenous Peoples and local communities have been conceived in the context of REDD+. One key issue concerns the modes through which rights to tenure, lands, and resources have been protected in REDD+ policies, programs, and projects. Are efforts to formalize these rights ultimately counterproductive because they undermine the traditional customary rights of communities? ${ }^{984}$ And does the creation of rights to carbon serve the interests of

$97^{8}$ For an overview of concerns over and conceptions of legitimacy in the field of environmental governance, see Daniel Bodansky, "The Legitimacy of International Governance: A Coming Challenge for International Environmental Law" (1999) 93 American Journal of International Law 596; Stephen Bernstein, "Legitimacy in Global Environmental Governance" (2005) 1 Journal of International Law \& International Relations 139.

979 Michael B. Likosky, "Editor's introduction: Transnational law in the context of power disparities," in Michael B. Likosky, eds., Transnational Legal Processes: Globalisation and Power Disparities (London, UK: Butterworths, 2002), xvii; Paul Street, "Stabilizing flows in the legal field: Illusions of permanence, intellectual property rights and the transnationalization of law" (2003) 3:1 Global Networks 7; Franz von Benda-Beckmann, Keebet von BendaBeckmann \& Anne Griffiths, eds., The Power of Law in a Transnational World: Anthropological Inquiries (New York, NY: Bergahn Books, 2009).

980 Sally Engle Merry, Human Rights and Gender Violence: Translating International Law into Local Justice (Chicago: University of Chicago Press, 2006).

$9^{81}$ Nico Krisch, “The Pluralism of Global Administrative Law" (2006) 17:1 European Journal of International Law 247.

$9^{82}$ See, e.g., Gralf-Peter Calliess \& Peer Zumbansen, Rough Consensus and Running Code: A Theory of Transnational Private Law (Oxford: Hart Publishing, 2010); Von Daniels, Detlef. The Concept of Law from a Transnational Perspective (Burlington, VT: Ashgate Publishing, 2010).

$9^{83}$ See, e.g., Mireille Delmas-Marty, Un pluralisme ordonné, Tome z Les forces imaginantes $d u$ droit (Paris, France: Seuil, 2006); Schiff Berman, Paul. Global Legal Pluralism: A Jurisprudence of Law beyond Borders (Cambridge, UK: Cambridge University Press, 2007).

$9^{84}$ Kirsty Gover, "REDD+, tenure, and indigenous property: The promise and peril of a human rights-based approach" in Voigt, supra note 17, 249. 
communities or are these rights inconsistent with Indigenous conceptions of nature ${ }^{985}$ Perhaps the most important matter relates to the recognition of the distinctive status and rights of Indigenous Peoples across multiple sites of law in the transnational legal process for REDD+. The findings in this book force us to consider whether Indigenous Peoples have a special and distinctive claim to an enhanced set of rights due to, as Macklem argues, our need to "mitigate some of the adverse consequences of how the international legal order continues to validate what were morally suspect colonisation projects by imperial powers"? ${ }^{96}$ Are Indigenous Peoples qualitatively different from other marginalized communities that live on or near forests due to their ability to form collective identities based on their special relationship with land ${ }^{987}$ Or is there something inequitable about providing rights to Indigenous Peoples, but not to other local communities who continue to experience the disabling effects of colonization in other ways and whose lives are also intimately connected to the forests, lands, and resources upon which they depend ${ }^{988}$ In my view, this challenging set of inquiries probably defies universal answers and instead requires the adoption of a rights-based approach tailored to each particular situation and building on the active engagement, if not leadership, of Indigenous Peoples and local communities..$^{99}$

The brief research agenda set out above reveals that REDD+ and its complex relationship to rights remains a vital area of scholarly inquiry. In addition to enhancing our understanding of REDD+, future research in this field promises to address difficult questions about the validity and legitimacy of transnational legal phenomena as well as the treatment and empowerment of marginalized groups in the context of environmental law and governance.

\section{IMPLICATIONS FOR THE STUDY OF TRANSNATIONAL \\ LEGAL PROCESSES}

While the primary aim of this book has lain in explaining how and to what effect legal norms relating to human rights were constructed and conveyed in the transnational legal process for REDD+, it also makes five important contributions to the scholarship on the concept of transnational legal processes principally developed by Koh, Shaffer, and Halliday. ${ }^{9{ }^{\circ}}$ First, my book

$9^{85}$ See Birrell, Godden \& Tehan, supra note 36.

986 Patrick Macklem, "Indigenous Recognition in International Law: Theoretical Observations" (2008) 30 Michigan Journal of International Law 177 at 179.

$9^{87} \quad$ Niezen, supra note 963. $\quad 9^{88} \quad$ Takacs, supra note 28; Ribot \& Larson, supra note 13.

$9^{89}$ Jodoin, supra note 271.

990 Koh, supra note 61; Shaffer, supra note 62; Halliday \& Shaffer, supra note 62. 
confirms the importance and value of anchoring the study of transnational legal processes in a legal pluralist perspective. By conceiving of law as a plural phenomenon that is not subsumed within a state-centric conception of law, I was able to trace the diverse ways in which legal norms relating to the rights of Indigenous Peoples and local communities were constructed and conveyed through and across multiple sites, modes, and forms of normative ordering. The legal scholarship on REDD+ and rights has adopted a largely positivist approach to law that focuses on state-centric understandings of national and international law, while neglecting other forms, modes, and levels of law that are relevant to understanding the different pathways through which REDD+ activities may affect or address the rights of Indigenous Peoples and local communities. ${ }^{991}$ By contrast, my approach conceives of law as a plural phenomenon that is not reducible to the formal norms and institutions associated with the state ${ }^{992}$ and recognizes moreover that law is affected by, and reflected in, the many forms of public and private governance that characterize contemporary transnational relations. ${ }^{993}$ This approach enabled me to study the role and influence of several forms and processes of normativity in the context of REDD+ that might traditionally be excluded as falling outside the scope of law, including those associated with the "soft law" decisions adopted by the UNFCCC, the voluntary project standards set by a certification program like the CCBA, the jurisdictional REDD+ policies adopted by the governments of Indonesia and Tanzania, and the project design documents of local REDD+ projects. ${ }^{994}$

instance, legal scholars have tended to analyze the "formal" decisions and processes within the UNFCCC (see, e.g., Savaresi, supra note 11; Lyster, supra note 17) and to assume that other sites and processes of law associated with REDD+ are unlikely to be effective in protecting rights because they lack "a clear legal basis" (Savaresi, supra note 11 at 109), are not "legally binding" (Rae, Gunther \& Godden, supra note 26 at 48), or are of "a voluntary nature" (Roht-Arriaza, supra note 39 at 232).

992 For a classic definition of legal pluralism, see Sally Engle Merry, "Legal Pluralism” (1988) 22:5 Law E Society Review 869.

993 Christian Brütsch \& Dirk Lehmkuhl, "Introduction" in in Christian Brüutsch \& Dirk Lehmkuhl, eds., Law and Legalization in Transnational Relations (Abingdon, UK: Routledge, 2007) 1.

994 This is not to say that formal international or domestic laws and institutions do not offer some advantages over less formal, less binding, or less authoritative manifestations of law. However, I would argue that the assumption that many legal scholars and practitioners hold to the effect that the latter set of initiatives are necessarily ineffective or less effective than formally binding international treaties or domestic laws is simply not sustainable. Indeed, thinking seriously about how multiple forms of normative ordering relate to society forces us to recognize that multiple sites of law have the potential to generate legal norms that can influence human behavior in meaningful ways and that the laws and institutions associated 
Second, my book illustrates the importance of understanding a transnational legal process as a cycle that moves back and forth between processes of construction and conveyance. By conceiving of legal norms both as "worksin-progress" that actors may develop together within sites of law (construction) and as "fixed entities" whose meaning and effects remain relatively stable as they migrate from one site of law to another (conveyance), I was able to capture the iterative nature of the migration and transformation of legal norms across sites of law. In particular, my in-depth process-tracing of the emergence and evolution of legal norms relating to the rights of Indigenous Peoples and local communities in the context of REDD+ suggests that the conveyance of exogenous legal norms in a site of law generally triggers the construction of hybrid legal norms at a later stage. As such, this book supports the notion that transnational legal processes tend to engender the translation rather than the transplantation of exogenous legal norms. 995

Third, this book illustrates the utility of identifying and studying the multiple causal mechanisms that account for the construction and conveyance of legal norms in a transnational legal process. Indeed, my examination of the spread and transformation of the rights of Indigenous Peoples and local communities across the UNFCCC, the CCBA, Indonesia, and Tanzania uncovered the role played by a multiplicity of causal mechanisms as well as the significance of interactions between these mechanisms. ${ }^{996}$ By thinking carefully about a range of causal mechanisms and their associate scope conditions, I was able to develop complex causal pathways that could account for the emergence, evolution, and effectiveness of the rights of Indigenous Peoples and local communities across a diversity of sites of law in the transnational legal process for REDD+. In turn, these causal pathways could be used to develop a typology of the

with the state may conversely fail to do so. In this regard, it is striking to recall that all of the developments and processes studied in this book essentially began with the adoption of what amounts to, in strictly legal positivist terms, a nonbinding decision to initiate negotiations on the creation of a REDD+ mechanism within the UNFCCC.

995 See generally Shaffer, supra note 62; Krook \& True, supra note 117; Goldbach, Brake \& Katzenstein, supra note 63; Merry, supra note 120. See, in particular, Cotterrell, supra note 126 at $109-116$.

${ }_{996}$ That said, my fieldwork did not uncover any evidence that exogenous actors have successfully used the provision of material assistance or conditions attached thereto to press for specific policy prescriptions in the adoption of national REDD+ strategies in Indonesia and Tanzania. This finding aligns with growing skepticism among scholars about the ability of coercion to directly affect the behavior of individuals. See Halliday \& Carruthers, supra note 62 at 11. 
causal pathways through which transnational legal processes may unfold, evolve, and exert influence. ${ }^{997}$

Fourth, this book shows that in addition to generating outcomes within particular sites of law, transnational legal processes can give rise to broader structural arrangements, particularly a broader domain of law that is characterized by heterogeneity and competition between sites of law and associated legal norms. At this stage, I have found little evidence of the institutionalization of a new transnational legal order in which legal norms relating to REDD+ or to the rights of Indigenous Peoples and local communities have converged to such a degree that they are taken for granted by actors across sites and levels of law. ${ }^{998}$ Rather, my findings suggest that the transnational legal process for REDD+, at least in its first decade, has engendered more conflict than order between sites of law and related clusters of legal norms.

Fifth, I believe that this book shows the benefits and limitations of processtracing as a research method for the study of transnational legal processes. The main benefit of process-tracing is that it enables scholars to draw strong inferences about the causal processes and mechanisms that link $\mathrm{X}$ and $\mathrm{Y}$ in a transnational legal process, which provides an opportunity to capture the complex and evolving nature and effects of legal norms as they move from one site of law to another. This offers the prospects of developing eclectic and multifaceted accounts and theories of the construction and conveyance of legal norms across sites of law. On the other hand, because it requires in-depth and time-intensive qualitative research, process-tracing is not ideal for studying phenomena such as isomorphism, diffusion, and convergence across a wide array of sites of law. ${ }^{999}$ This suggests the utility of a nested research design that would combine both quantitative methods to uncover broad trends in the spread and adoption of legal norms across a population of cases ${ }^{1000}$ and qualitative methods that can trace why, how, and to what effect these legal norms have been conveyed and constructed in a small number of cases. In

997 1409-1411 and by Risse, Ropp, and Sikkink, supra note 130, 138. See also Risse \& Ropp, supra note 99 .

$99^{8}$

999

Then again, my analysis suggests that isomorphism, diffusion, and convergence are often contingent and frequently reflect one stage in the cycle through which legal norms are conveyed in a transnational legal process.

1000 See, e.g., Paulette Lloyd \& Beth A. Simmons, "Framing for a New Transnational Legal Order: The Case of Human Trafficking" in Halliday \& Shaffer, supra note 62, 400. 
general, carefully designed empirical research projects like the one presented in this book should become a key priority in the study of transnational legal processes in the years to come.

\section{REDD+ AND THE INTERSECTIONS OF HUMAN RIGHTS AND ENVIRONMENTAL GOVERNANCE}

This book has three important implications for global efforts to operationalize REDD+ on the ground. First, my book underscores the potential that a range of instruments and approaches can play in ensuring that REDD+ activities support, rather than infringe upon, the rights of Indigenous Peoples and local communities in developing countries. Rather than focus on any single instrument, policy-makers should support a range of REDD+ initiatives that create economic and political incentives for respecting, protecting, and fulfilling human rights, enable multiple actors to engage in deliberative processes to develop shared understandings about the importance of respecting these rights, and empower Indigenous Peoples and local communities so that they are well-positioned to seek the recognition and protection of their rights at the local, national, and international levels. In doing so, policy-makers should not underestimate the important opportunities that are provided by "informal" or "nonbinding" instruments for the construction and conveyance of human rights norms across sites of law. Most importantly, policy-makers should think carefully about the causal logics through which interventions can influence the behavior of relevant actors and how these can complement one another in synergistic ways to engender positive outcomes for REDD+ and human rights.

Second, this book offers new insights on the tensions and synergies between the promotion of community forestry and the global effort to reduce carbon emissions from forest-based sources in developing countries. As is evinced by my case studies of the take-up of community-based approaches to forest governance in the design of jurisdictional and project-based REDD+ activities in Indonesia and Tanzania, the effectiveness of community forestry as a policy instrument depends largely on the legal, political, economic, and environmental context in which it is implemented. My research in Indonesia suggests that the pursuit of community forestry through REDD+ is unlikely to lead to significant reductions in GHG emissions in landscapes where deforestation is driven by large-scale economic activities that are linked to global supply chains for commodities, such as logging, agriculture, and mining, and where powerful actors stand to lose from the recognition and enforcement of the forest and resource rights of local communities. Solutions to forest loss in these landscapes must instead address the incentives for the unsustainable 
exploitation of forests that are embedded within global supply chains. Conversely, as is shown by the experience of Tanzania, community forestry may offer a more promising basis upon which to implement a REDD+ policy or project in contexts where the drivers of deforestation are closely connected to the activities of local communities and where it is feasible, both legally and politically, to strengthen and enforce community tenure and authority in and over forests. In other words, whatever merits it may have in terms of advancing the rights and dignity of communities, community forestry should not be seen as a "one-size-fits-all" solution to the complex problems of deforestation and climate change.

A third important practical implication of my research pertains to the governance of the transnational legal process for REDD+. My findings regarding the conveyance and construction of human rights norms in the context of REDD+ activities across Indonesia and Tanzania provide a powerful illustration of the broader politics that have characterized the transnational legal process for REDD+ since 2007 . On the whole, I have found that the emergence, spread, and implementation of various types of REDD+ activities have been characterized by the competing ideas, interests, and initiatives of various public and private actors operating at multiple levels. To be sure, this sort of diversity has its advantages in that it may offer opportunities for experimentation and learning that could be used by policy-makers to adjust and calibrate various policy instruments and initiatives for reducing carbon emissions from forest-based sources in developing countries. Yet, too much diversity and competition between transnational actors and legal norms may also hinder the effectiveness of global efforts to support the implementation of REDD+ in developing countries, especially if initiatives overwhelm practitioners in developing countries with additional or incoherent sets of legal norms. In this regard, my research thus points to the need for various actors and institutions to ensure greater complementarity in the construction and conveyance of legal norms for REDD+ across sites and levels of law, ${ }^{1001}$ while at the same time providing scope for continued diversity and mutual learning. ${ }^{1002}$

While focused on REDD+, this ambitious policy agenda ultimately speaks to the broader set of concerns that arise from the relationship between the fields of human rights and environmental governance. At this stage, much of the existing knowledge on the relationship between these two fields has tended

1001 Indeed, the recent collaborations that have emerged between the World Bank FCPF and the UN-REDD Programme or between the VCS and CCBA suggest that actors are increasingly recognizing the need to tackle the challenges associated with the fragmentation of REDD+.

1002 This could be done through the adoption of a "policy-centric" approach to the governance of REDD+; Nagendra \& Ostrom, supra note 42 at 121-124. 
to adopt one-dimensional assumptions about the need for environmental policy-making and governance to draw on the language, norms, and machinery of human rights in order to achieve legal, social, and policy change. ${ }^{1003}$ Rather than view human rights as a source of inspiration and change for the environmental field, my book underscores the many ways in which environmental efforts may clash with the protection of the rights of Indigenous Peoples and local communities in developing countries. However urgent the climate crisis may be, solutions for a low-carbon future should not come at the expense of the rights of marginalized communities that they ultimately seek to serve. ${ }^{1004}$ This view is reflected in the preamble to the Paris Agreement adopted in December 2015, which acknowledges that "Parties should, when taking action to address climate change, respect, promote and consider their respective obligations on human rights, the right to health, the rights of indigenous peoples, local communities, migrants, children, persons with disabilities and people in vulnerable situations and the right to development, as well as gender equality, empowerment of women and intergenerational equity." 1005

At the same time, my research also provides an opportunity to consider the potential and limitations of seizing the indirect and unanticipated opportunities offered by the mechanisms and processes of transnational environmental governance for the recognition and protection of human rights. The notion that a forest carbon finance mechanism like REDD+ could serve as an opportunity for the conveyance and translation of the rights of Indigenous Peoples and local communities had appeared rather unlikely, given the record of rights-related abuses associated with the first generation of public and private carbon sequestration mechanisms implemented in developing countries. ${ }^{1006}$ The fairly positive implications of REDD+ for Indigenous Peoples and local communities reported in this book are all the more surprising since many of the actors who have recognized Indigenous and community rights in

1003 See, e.g., Ken Conca, "Environmental Governance after Johannesburg: From Stalled Legalization to Environmental Human Rights?" (2006) 1:1-2 Journal of International Law and International Relations 121; Simon Nicholson \& Daniel Chong, "Jumping on the Human Rights Bandwagon: How Rights-Based Linkages Can Refocus Climate Politics" (2011) 11:3 Global Environmental Politics 121.

1004 Lee Godden \& Maureen Tehan, "REDD+: Climate justice and indigenous and local community rights in an era of climate disruption" (2016) 34:1 Journal of Energy E Natural Resources Law 95.

1005 Paris Agreement, preamble.

${ }_{1006}$ Steffen Böhm \& Siddhartha Dabhi, eds., Upsetting the Offset: The Political Economy of Carbon Markets (San Francisco, CA: Zed Books, 2009). 
the context of REDD+ had been averse to doing so in the past. ${ }^{1007}$ As such, the spread of rights across the domain of REDD+ goes against earlier conventional wisdom that it would have broadly negative repercussions for the rights of Indigenous Peoples and local communities. ${ }^{1008}$ Of course, it is entirely possible that the recognition of these rights is largely symbolic and that their practical implementation remains constrained by existing structural, legal, economic, and political asymmetries. Only time will tell whether or not the gains achieved in the recognition of participatory and resource rights in the context of REDD+ will actually benefit Indigenous peoples and local communities in meaningful ways. As the points of contact between the fields of human rights and environmental governance continue to multiply, it will be increasingly important to think about the complex ways in which these fields may affect one another and to pursue, whenever possible, mutually complementary solutions that can accommodate their central concerns and objectives through innovative policy and advocacy activities.

1007 The recognition of the rights of Indigenous Peoples and forest-dependent communities has encountered historical resistance across many of the actors engaged in the operationalization of REDD+, including multilateral institutions such as the UNFCCC, conservation NGOs, and developing country governments in Asia and Africa.

1008 Simone Lovera, "Rights and REDD: Can They Be Matched?" (2010) 17 Policy Matters 40. 


\section{Annex I}

\section{Overview of REDD+ Activities in the Developing World}

\begin{tabular}{|c|c|c|c|c|c|}
\hline Country & $\begin{array}{l}\text { UN-REDD } \\
\text { program status }\end{array}$ & FCPF status & FIP status & $\begin{array}{l}\text { NICFI } \\
\text { partner }\end{array}$ & $\begin{array}{l}\text { Number } \\
\text { of REDD+ } \\
\text { projects }^{1009}\end{array}$ \\
\hline Angola & No & No & No & No & o \\
\hline Argentina & $\begin{array}{l}\text { National } \\
\text { Program }\end{array}$ & Participant & No & No & 3 \\
\hline Bangladesh & $\begin{array}{l}\text { National } \\
\text { Program }\end{array}$ & No & No & No & O \\
\hline Belize & No & Participant & No & No & 3 \\
\hline Benin & Partnership & No & No & No & o \\
\hline Bhutan & Partnership & Participant & No & No & o \\
\hline Bolivia & $\begin{array}{l}\text { National } \\
\text { Program }\end{array}$ & Participant & No & No & 8 \\
\hline Brazil & No & No & Pilot Country & Yes & 56 \\
\hline Burkina Faso & No & Participant & Pilot Country & No & 0 \\
\hline Burundi & No & Candidate & No & No & o \\
\hline Cambodia & $\begin{array}{l}\text { National } \\
\text { Program }\end{array}$ & Participant & No & No & 4 \\
\hline Cameroon & Partnership & Participant & No & No & 4 \\
\hline $\begin{array}{c}\text { Central African } \\
\text { Republic }\end{array}$ & Partnership & Participant & No & No & 1 \\
\hline Chad & Partnership & Candidate & No & No & o \\
\hline Chile & Partnership & Participant & No & No & 4 \\
\hline China & No & No & No & No & 12 \\
\hline
\end{tabular}

1009 See CIFOR, "Global database of REDD+ and other forest carbon projects Interactive map," available at: www.forestsclimatechange.org/redd-map/ (accessed 10 June 2014). A less comprehensive but more accurate list of REDD+ projects is the one compiled by the REDD+ Desk: REDD+ Desk, "REDD Countries" available at: http://theredddesk.org/countries (accessed 24 November 2014). 
(cont.)

\begin{tabular}{|c|c|c|c|c|c|}
\hline Country & $\begin{array}{l}\text { UN-REDD } \\
\text { program status }\end{array}$ & FCPF status & FIP status & $\begin{array}{l}\text { NICFI } \\
\text { partner }\end{array}$ & $\begin{array}{l}\text { Number } \\
\text { of REDD+ } \\
\text { projects }\end{array}$ \\
\hline Colombia & $\begin{array}{l}\text { National } \\
\text { Program }\end{array}$ & Participant & No & No & 10 \\
\hline Costa Rica & Partnership & Participant & No & No & 6 \\
\hline DRC & $\begin{array}{l}\text { National } \\
\text { Program }\end{array}$ & Participant & Pilot Country & No & 11 \\
\hline Ecuador & $\begin{array}{l}\text { National } \\
\text { Program }\end{array}$ & No & No & No & 13 \\
\hline El Salvador & No & Participant & No & No & 1 \\
\hline $\begin{array}{c}\text { Equatorial } \\
\text { Guinea }\end{array}$ & Partnership & No & No & No & ○ \\
\hline Ethiopia & Partnership & Participant & No & No & 3 \\
\hline Fiji & No & Participant & No & No & 1 \\
\hline Gabon & Partnership & Participant & No & No & 1 \\
\hline Georgia & No & No & No & No & 1 \\
\hline Ghana & Partnership & Participant & Pilot Country & No & 2 \\
\hline Guatemala & Partnership & Participant & No & No & 6 \\
\hline Guyana & Partnership & Participant & No & Yes & 1 \\
\hline Honduras & Partnership & Participant & No & No & 1 \\
\hline India & No & No & No & No & 13 \\
\hline Indonesia & $\begin{array}{l}\text { National } \\
\text { Program }\end{array}$ & Participant & Pilot Country & Yes & 44 \\
\hline Ivory Coast & No & No & No & No & 1 \\
\hline Jamaica & No & Candidate & No & No & o \\
\hline Kenya & Partnership & Participant & No & No & 12 \\
\hline Laos & Partnership & Participant & Pilot Country & No & 1 \\
\hline Liberia & No & Participant & No & No & 2 \\
\hline Madagascar & Partnership & Participant & No & No & 7 \\
\hline Malaysia & Partnership & No & No & No & 1 \\
\hline Mali & No & No & No & No & o \\
\hline Mexico & Partnership & Participant & Pilot Country & Yes & 5 \\
\hline Moldova & No & No & No & No & 2 \\
\hline Mongolia & $\begin{array}{l}\text { National } \\
\text { Program }\end{array}$ & No & No & No & ○ \\
\hline Morocco & Partnership & No & No & No & o \\
\hline Mozambique & No & Participant & No & No & 5 \\
\hline Myanmar & Partnership & No & No & No & o \\
\hline Nepal & Partnership & Participant & No & No & 1 \\
\hline Nicaragua & No & Participant & No & No & 2 \\
\hline Nigeria & $\begin{array}{l}\text { National } \\
\text { Program }\end{array}$ & Participant & No & No & 1 \\
\hline
\end{tabular}


(cont.)

\begin{tabular}{|c|c|c|c|c|c|}
\hline Country & $\begin{array}{l}\text { UN-REDD } \\
\text { program status }\end{array}$ & FCPF status & FIP status & $\begin{array}{l}\text { NICFI } \\
\text { partner }\end{array}$ & $\begin{array}{l}\text { Number } \\
\text { of REDD+ } \\
\text { projects }\end{array}$ \\
\hline Pakistan & Partnership & Participant & No & No & o \\
\hline Panama & $\begin{array}{l}\text { National } \\
\text { Program }\end{array}$ & Participant & No & No & 7 \\
\hline $\begin{array}{c}\text { Papua New } \\
\text { Guinea }\end{array}$ & $\begin{array}{l}\text { National } \\
\text { Program }\end{array}$ & Participant & No & No & 4 \\
\hline Paraguay & $\begin{array}{l}\text { National } \\
\text { Program }\end{array}$ & Participant & No & No & 5 \\
\hline Peru & Partnership & Participant & Pilot Country & No & 38 \\
\hline Philippines & $\begin{array}{l}\text { National } \\
\text { Program }\end{array}$ & Candidate & No & No & 4 \\
\hline $\begin{array}{c}\text { Republic of } \\
\text { Congo }\end{array}$ & $\begin{array}{l}\text { National } \\
\text { Program }\end{array}$ & No & No & No & o \\
\hline Romania & No & No & No & No & 1 \\
\hline Rwanda & No & No & No & No & ० \\
\hline $\begin{array}{l}\text { Sao Tomé and } \\
\text { Principe }\end{array}$ & No & No & No & No & o \\
\hline Sierra Leone & No & No & No & No & ○ \\
\hline $\begin{array}{l}\text { Solomon } \\
\text { Islands }\end{array}$ & $\begin{array}{l}\text { National } \\
\text { Program }\end{array}$ & No & No & No & ○ \\
\hline South Africa & No & No & No & No & o \\
\hline South Sudan & Partnership & Candidate & No & No & o \\
\hline Sri Lanka & $\begin{array}{l}\text { National } \\
\text { Program }\end{array}$ & Candidate & No & No & o \\
\hline Sudan & Partnership & Participant & No & No & o \\
\hline Suriname & Partnership & Participant & No & No & o \\
\hline Tanzania & $\begin{array}{l}\text { National } \\
\text { Program }\end{array}$ & Participant & No & Yes & 10 \\
\hline Thailand & No & Participant & No & No & 1 \\
\hline Togo & No & Participant & No & No & o \\
\hline $\begin{array}{c}\text { Trinidad and } \\
\text { Tobago }\end{array}$ & No & No & No & No & 1 \\
\hline Uganda & Partnership & Participant & No & No & 5 \\
\hline Uruguay & No & Participant & No & No & 2 \\
\hline Vanuatu & No & Participant & No & No & 1 \\
\hline Venezuela & No & No & No & No & 1 \\
\hline Viet Nam & $\begin{array}{l}\text { National } \\
\text { Program }\end{array}$ & Participant & No & No & 7 \\
\hline Zambia & $\begin{array}{l}\text { National } \\
\text { Program }\end{array}$ & No & No & No & 1 \\
\hline Zimbabwe & Partnership & No & No & No & o \\
\hline
\end{tabular}




\section{Bibliography}

\section{JOURNAL ARTICLES}

Abbott, Kenneth W. \& Duncan Snidal. "Hard and Soft Law in International Governance" (2009) 54: 3 International Organization 421.

Abbott, Kenneth W. et al. "The Concept of Legalization" (2000) 54: 3 International Organization 401.

Abbott, Kenneth W. "The Transnational Regime Complex for Climate Change” (2012) 30 Environment and Planning C: Government and Policy 571.

Afiff, Suraya \& Celia Lowe. "Claiming Indigenous Community: Political Discourse and Natural Resource Rights in Indonesia" (2007) 32 Alternatives: Global, Local, Political 73.

Andonova, Liliana B., Michele M. Betsill \& Harriet Bulkeley. “Transnational Climate Governance" (2009) 9: 2 Global Environmental Politics 52.

Arnold, Luke Lazarus. "Deforestation in Decentralised Indonesia: What's Law Got to Do with It?" (2008) 4: 2 Law, Environment and Development Journal 75 .

Awono, Abdon et al. "Tenure and Participation in Local REDD+ Projects: Insights from Southern Cameroon" (2014) 35 Environmental Science \& Policy 76.

Bakker, Laurens \& Sandra Moniaga. "The Space between: Land Claims and the Law in Indonesia" (2010) 38: 2 Asian Journal of Social Science 187.

Bartley, Tim. "Transnational Governance as the Layering of Rules: Intersections of Public and Private Standards" (2011) 12: 2 Theoretical Inquiries in Law 519.

Bernstein, Stephen. "Legitimacy in Global Environmental Governance" (2005) 1 Journal of International Law \& International Relations 139.

Bernstein, Steven \& Benjamin Cashore. "Can Non-State Global Governance Be Legitimate? An Analytical Framework" (2007) 1 Regulation \& Governance 347.

"Complex Global Governance and Domestic Policies: Four Pathways of Influence" (2012) 88: 3 International Affairs 585.

Beymer-Farris, Betsy A. \& Thomas J. Bassett. "The REDD Menace: Resurgent Protectionism in Tanzania's Mangrove Forests" (2012) 22: 2 Global Environmental Change 332. 
Birrell, Kathleen, Lee Godden \& Maureen Tehan. "Climate Change and REDD+: Property as a Prism for Conceiving Indigenous Peoples' Engagement” (2012) 3:2 Journal of Human Rights and the Environment 196.

Blomley, Tom et al. "Seeing the Wood for the Trees: An Assessment of the Impact of Participatory Forest Management on Forest Condition in Tanzania" (2008) 42: 3 Oryx 380.

Bluffstone, Randy, Elizabeth Robinson \& Paul Guthiga. "REDD+ and CommunityControlled Forests in Low-Income Countries: Any Hope for a Linkage?” (2013) 87 Ecological Economics 43.

Bodansky, Daniel. "The Legitimacy of International Governance: A Coming Challenge for International Environmental Law" (1999) 93 American Journal of International Law 596.

Boyd, Emily, Esteve Corbera \& Manuel Estrada. "UNFCCC Negotiations (Pre-Kyoto to COP-9): What the Process Says about the Politics of CDM-sinks" (2008) 8 International Environmental Agreements 95.

Boyd, William. "Ways of Seeing in Environmental Law: How Deforestation Became an Object of Climate Governance" (2010) 37 Ecology Law Quarterly 843.

Boyle, Elizabeth \& Sharon E. Preves. "National Politics as International Process: The Case of Anti-Female-Genital-Cutting Laws" (2000) 34: 3 Law E Society Review 703.

Brake, Benjamin \& Peter J. Katzenstein. "Lost in Translation? Nonstate Actors and the Transnational Movement of Procedural Law" (2013) 67: 4 International Organization 725 .

Brunée, Jutta. "COPing with Consent: Law-Making under Multilateral Environmental Agreements" (2002) 15: 1 Leiden Journal of International Law 1.

Buizer, Marleen, David Humphreys \& Wil de Jong. "Climate Change and Deforestation: The Evolution of an Intersecting Policy Domain” (2013) 35 Environmental Science \& Policy 1.

Burgess, Neil D. et al. "Getting Ready for REDD+ in Tanzania: a Case Study of Progress and Challenges" (2010) 44: 3 Oryx 339.

Cameron, Edward \& Marc Limon. "Restoring the Climate by Realizing Rights: The Role of the International Human Rights System" (2012) 21: 3 Review of European Community \& International Environmental Law 204.

Cerbu, Gillian A., Brent M. Swallow \& Dara Y. Thompson. "Locating REDD: A Global Survey and Analysis of REDD Readiness and Demonstration Activities" (2011) 14: 2 Environmental Science \& Policy 168.

Checkel, Jeffrey T. "International Institutions and Socialization in Europe: Introduction and Framework" (2005) 59: 4 International Organization 801.

"Why Comply? Social Learning and European Identity Change" (2001) 55: 3 International Organization 553.

"International Norms and Domestic Politics: Bridging the Rationalist-Constructivist Divide" (1997) 3: 4 European Joumal of International Relations 473.

"Process Tracing" in Audie Klotz \& Deepa Prakash, eds., Qualitative Methods in International Relations. A Pluralist Guide (New York, NY: Palgrave Macmillan, 2008) 114 .

Chhatre, Ashwini \& Arun Agrawal. "Tradeoffs and Synergies between Carbon Storage and Livelihood Benefits from Forest Commons" (2009) 106: 42 Proceedings of the National Academy of Sciences 17667. 
Chhatre, Ashwini et al. "Social Safeguards and Co-Benefits in REDD+: A Review of the Adjacent Possible" (2012) 4: 6 Current Opinion in Environmental Sustainability 654.

Conca, Ken. "Environmental Governance after Johannesburg: From Stalled Legalization to Environmental Human Rights?” (2006) 1: 1-2 Journal of International Law and International Relations 121.

Corbera, Esteve \& Heike Schroeder. "Governing and implementing REDD+" (2011) 14: 2 Environmental Science \& Policy 89.

Corbera, Esteve et al. "Rights to Land, Forests and Carbon in REDD+: Insights from Mexico, Brazil and Costa Rica" (2011) 2 Forests 301.

Costenbader, John. Legal Frameworks for REDD Design and Implementation at the National Level, IUCN Environmental Policy and Law Paper 77 (2009).

Cronkleton, Peter, David Barton Bray \& Gabriel Medina. "Community Forest Management and the Emergence of Multi-Scale Governance Institutions: Lessons for REDD+ Development from Mexico, Brazil and Bolivia” (2011) 2: 2 Forests 451.

de la Fuente, Theresa \& Reem Hajjar. "Do Current Forest Carbon Standards Include Adequate Requirements to Ensure Indigenous Peoples' Rights in REDD Projects ?” (2013) 15: 4 International Forestry Review 1.

Di Gregorio, Monica et al. "Equity and REDD+ in the Media: A Comparative Analysis of Policy Discourses" (2013) 18: 2 Ecology \& Society Art. 39.

Dobbin, Frank, Beth Simmons \& Geoffrey Garrett. "The Global Diffusion of Public Policies: Social Construction, Coercion, Competition, or Learning?” (2007) 33 Annual Review of Sociology 449.

Doherty, Emma \& Heike Schroeder. "Forest Tenure and Multi-level Governance in Avoiding Deforestation under REDD+” (2011) 11: 4 Global Environmental Politics 66.

Dokken, Therese et al. "Tenure Issues in REDD+ Pilot Project Sites in Tanzania" (2014) 5: 2 Forests 234.

Duchelle, Amy et al. "Linking Forest Tenure Reform, Environmental Compliance, and Incentives: Lessons from REDD+ Initiatives in the Brazilian Amazon" (2014) 55 World Development 53.

Ellis, Jaye. "Fisheries Conservation in an Anarchical System: A Comparison of Rational Choice and Constructivist Perspectives" (2007) 3 Journal of International Law E International Relations 1.

Engle Merry, Sally. "Legal Pluralism” (1988) 22: 5 Law \& Society Review 869.

"New Legal Realism and the Ethnography of Transnational Law" (2006) 31: 4 Law E Social Inquiry 975.

"Transnational Human Rights and Local Activism: Mapping the Middle" (2006) 108: 1 American Anthropologist 38.

Erlanger, Howard et al. "Is It Time for a New Legal Realism?" (2005) 2 Wisconsin Law Review 335 .

Evans, Kristen, Laura Murphy \& Wil de Jong. "Global versus Local Narratives of REDD: A Case Study from Peru's Amazon” (2014) 35 Environmental Science \& Policy 98.

Falleti, Tulia G. \& Julia F. Lynch. "Context and Causal Mechanisms in Political Analysis” (2009) 42: 9 Comparative Political Studies 1143. 
Fernanda Tomaselli, Maria \& Reem Hajjar. "Promoting Community Forestry Enterprises in National REDD+ Strategies: A Business Approach" (2011) 2: 1 Forests 283 .

French, Duncan \& Lavanya Rajamani. "Climate Change and International Environmental Law: Musings on a Journey to Somewhere" (2013) 25 Journal of Environmental Law 1.

Godden, Lee \& Maureen Tehan, "REDD+: Climate Justice and Indigenous and Local Community Rights in an Era of Climate Disruption" (2016) 34: 1 Journal of Energy ङ Natural Resources Law 95-108.

Godoy, Fabiano L. "Deforestation and $\mathrm{CO}_{2}$ Emissions in Coastal Tanzania from 1990 to 2007 " (2011) 39: 1 Environmental Conservation 62.

Goldbach, Toby S., Benjamin Brake \& Peter J. Katzenstein. "The Movement of U.S. Criminal and Administrative Law: Processes of Transplanting and Translating" (2013) 20: 1 Indiana Journal of Global Legal Studies 141.

Goldstein, Judith \& Lisa Martin. "Legalization, Trade Liberalization, and Domestic Politics”, (2000) 54: 3 International Organization 603.

Green, Jessica F. "Order out of Chaos: Public and Private Rules for Managing Carbon" (2013) 13: 2 Global Environmental Politics 1.

Hafner-Burton, Emilie M. \& James Ron. "Seeing Double: Human Rights Impact through Qualitative and Quantitative Eyes" (2009) 61: 2 World Politics 360.

Hall, Peter. "Policy Paradigms, Social Learning, and the State: The Case of Economic Policymaking in Britain" (1993) 25: 3 Comparative Politics 275.

Halliday, Terence C. \& Pavel Osinsky. "Globalization of Law" (2006) 32 Annual Review of Sociology 447.

Halliday, Terence C. \& Bruce G. Carruthers. "The Recursivity of Law: Global Norm Making and National Lawmaking in the Globalization of Corporate Insolvency Regimes" (2007) 112: 4 American Journal of Sociology 1135.

Hayes, Tanya \& Lauren Persha. "Nesting Local Forestry Initiatives: Revisiting Community Forest Management in a REDD+ World" (2010) 12(8) Forest Policy ङ Economics 545 .

Hodgson, Dorothy L. "Precarious Alliances: The Cultural Politics and Structural Predicaments of the Indigenous Rights Movement in Tanzania" (2002) American Anthropologist 108.

Howlett, Michael \& M Ramesh. "The Policy Effects of Internationalization: A Subsystem Adjustment Analysis of Policy Change” (2002) 4: 1 Journal of Comparative Policy Analysis 31.

Igoe, Jim. "Becoming Indigenous Peoples: Difference, Inequality, and the Globalization of East African Identity Politics" (2006) 105/420 African Affairs 399.

"Scaling Up Civil Society: Donor Money, NGOs, and the Pastoralist Rights Movement in Tanzania" (2003) 34: 5 Development and Change 863.

Jodoin, Sébastien. "Can Rights-Based Approaches Enhance Legitimacy and Cooperation in Conservation? A Relational Account" (2014) 15: 3 Human Rights Review 283.

Jodoin, Sébastien \& Sarah Mason-Case, "What Difference Does CBDR Make? A Socio-Legal Analysis of the Role of Differentiation in the Transnational Legal Process for REDD+” (2016) 5: 2 Transnational Environmental Law 255. 
Kanowski, Peter J., Constance L. McDermott \& Benjamin Cashore. "Implementing REDD+: Lessons from Analysis of Forest Governance" (2010) 14: 2 Environmental Science \& Policy 111.

Kato, Tsuyoshi. "Different Fields, Similar Locusts: Adat Communities and the Village Law of 1979 in Indonesia" (1989) 47 Indonesia 89.

Kelly, David J. "The Case for Social Safeguards in a Post-2o12 Agreement on REDD” (2010) 6: 1 Law, Environment and Development Journal 61.

Kingsbury, Benedict. “'Indigenous Peoples' in International Law: A Constructivist Approach to the Asian Controversy" (1998) 92: 3 American Joumal of International Law 414 .

Knox, Anna et al. "Land Tenure and Payment for Environmental Services. Challenges and Opportunities for REDD+" (2011) 11: 2 Land Tenure Journal 17.

Koh, Harold Hongju. "1998 Harris Lecture: How Is International Human Rights Law Enforced?” (1999) 74 Indiana Law Journal 1397.

"Transnational Legal Process" (1996) 75 Nebraska Law Review 181.

Krisch, Nico. "The Pluralism of Global Administrative Law" (2006) 17: 1 European Journal of International Law 247.

Krook, Mona Lena \& Jacqui True. "Rethinking the Life Cycles of International Norms: The United Nations and the Global Promotion of Gender Equality" (2010) 18: 1 European Journal of International Relations 103.

Laltaoka, Elifuraha Isaya. "Indigenous Peoples' Rights in Tanzania and International Rights Law" (2012) 1: 1 TUMA Law Review 147.

"Pastoralists' Right to Land and Natural Resources in Tanzania" (2013) 15 Oregon Review of International Law 43.

Lambin, Eric F. \& Patrick Meyfroidt. "Global Land Use Change, Economic Globalization, and the Looming Land Scarcity" (2011) 108: 9 PNAS 3465.

Larrazábal, Alejandra, Michael K. McCall, Tuyeni H. Mwampamba \& Margaret Skutsch, "The Role of Community Carbon Monitoring for REDD+: A Review of Experiences" (2012) Current Opinion in Environmental Sustainability 707.

Larson, Anne M. \& Elena Petkova. "An Introduction to Forest Governance, People and REDD+ in Latin America: Obstacles and Opportunities” (2011) 2: 1 Forests 86.

Larson, Anne M et al. "Land tenure and REDD+: The Good, the Bad and the Ugly" (2013) 23: 3 Global Environmental Change 678.

Larson, Anne M. "Forest Tenure Reform in the Age of Climate Change: Lessons for REDD+” (2011) 21: 2 Global Environmental Change 540.

Lawlor, Kathleen et al. "Community Participation and Benefits in REDD+: A Review of Initial Outcomes and Lessons" (2013) 4: 2 Forests 296.

Lawlor, Kathleen, Erika Weinthal \& Lydia Olander. "Institutions and Policies to Protect Rural Livelihoods in REDD+ Regimes" (2010) 10: 4 Global Environmental Politics 1.

Leggett, Matthew \& Heather Lovell. (2012) "Community Perceptions of REDD+: A Case Study in PNG” (2012) 12: 1 Climate Policy 115.

Lemaitre, Sophie. "Indigenous Peoples' Land Rights and REDD: A Case Study" (2011) 20: 2 Review of European Community \& International Environmental Law 150.

Levin, Janet K. "Bottom-Up Lawmaking: The Private Origins of Transnational Law" (2008) 15 Indiana Journal of Global Legal Studies 49. 
Lovera, Simone. "Rights and REDD: Can They Be Matched?" (2010) 17 Policy Matters 40.

Ludwig, Grit. "Property Rights and Participation in REDD+: The Case of Mozambique" (2012) 1: 2 Transnational Environmental Law 381.

Luttrell, Cecilia et al. "Who Should Benefit from REDD+? Rationales and Realities" (2013) 18: 4 Ecology \& Society 52.

Lyster, Rosemary. "REDD+, Transparency, Participation and Resource Rights: The Role of Law" (2011) 14: 2 Environmental Science G Policy 118.

Macklem, Patrick. "Indigenous Recognition in International Law: Theoretical Observations" (2008) 30 Michigan Journal of International Law 177.

Mahanty, Sango \& Constance L. McDermott. "How Does 'Free, Prior and Informed Consent' (FPIC) Impact Social Equity? Lessons from Mining and Forestry and Their Implications for REDD+" (2013) 35 Land Use Policy 406.

March, James G. \& Johan P. Olsen. "The Institutional Dynamics of International Political Orders" (1998) 52: 4 International Organization 943.

McCann, Michael. "Law and Social Movements: Contemporary Perspectives" (2006) 2: 1 Annual Review of Law and Social Science 17.

McDermott, Constance L. et al. "Operationalizing Social Safeguards in REDD+: Actors, Interests and Ideas” (2012) 21 Environmental Science \& Policy 63.

McDermott, Constance L., Kelly Levin \& Benjamin Cashore. "Building the ForestClimate Bandwagon: REDD+ and the Logic of Problem Amelioration" (2011) 11: 3 Global Environmental Politics 85.

Melo, Isabel, Esther Turnhout \& Bas Arts. "Integrating Multiple Benefits in Market-Based Climate Mitigation Schemes: The Case of the Climate, Community and Biodiversity Certification Scheme” (2014) 35: 2009 Environmental Science E Policy 49.

Merger, Eduard, Margaret Dutschke \& Louis Verchot. "Options for REDD+ Voluntary Certification to Ensure Net GHG Benefits, Poverty Alleviation, Sustainable Management of Forests and Biodiversity Conservation" (2011) 2 Forests 550 .

Meyer, Christopher \& Dana Miller. "Zero Deforestation Zones: The Case for Linking Deforestation-Free Supply Chain Initiatives and Jurisdictional REDD+” (2015) 34 Joumal of Sustainable Forestry 559.

Miller, Jonathan. "A Typology of Legal Transplants: Using Sociology, Legal History and Argentine Examples to Explain the Transplant Process" (2003) 51 American Journal of Comparative Law 839.

Murray Li, Tania. "Articulating Indigenous Identity in Indonesia: Resource Politics and the Tribal Slot" (2000) 42: 1 Comparative Studies in Society and History 149.

"Masyarakat Adat, Difference, and the Limits of Recognition in Indonesia's Forest Zone" (2001) 35;3 Modern Asian Studies 645.

Mustalahti, Irmeli et al. "Can REDD + Reconcile Local Priorities and Needs with Global Mitigation Benefits? Lessons from Angai Forest, Tanzania” (2012) 17: 1 Ecology 6 Society 16.

Nagendra, Harini \& Elinor Ostrom. "Polycentric Governance of Multifunctional Forested Landscapes" (2012) 6: 2 International Journal of the Commons 104.

Nepstad, Daniel et al. "More Food, More Forests, Fewer Emissions, Better Livelihoods: Linking REDD+, Sustainable Supply Chains and Domestic Policy in Brazil, Indonesia and Colombia” (2013) 4: 6 Carbon Management 639. 
Nicholson, Simon \& Daniel Chong. "Jumping on the Human Rights Bandwagon: How Rights-Based Linkages Can Refocus Climate Politics" (2011) 11: 3 Global Environmental Politics 121.

Niezen, Ronald. “The Indigenous Claim for Recognition in the International Public Sphere" (2005) 17 Florida Journal of International Law 583.

Okereke, Chukwumerije \& Kate Dooley. "Principles of Justice in Proposals and Policy Approaches to Avoided Deforestation: Towards a Post-Kyoto Climate Agreement" (2010) 20: 1 Global Environmental Change 82.

Palmer Fry, Ben. "Community Forest Monitoring in REDD+: The 'M' in MRV?" (2011) 14: 2 Environmental Science and Policy 181.

Payne, Rodger. "Persuasion, Frames and Norm Construction" (2001) 7: 1 European Journal of International Relations 37.

Peach Brown, H.C. "Gender, Climate Change and REDD+ in the Congo Basin Forests of Central Africa" (2011) 13: 2 International Forestry Review 163.

Pettenella, Davide \& Lucio Brotto. "Governance Features for Successful REDD+ Projects Organization" (2011) 18 Forest Policy \& Economics 46.

Phelps, Jacob, Edward L. Webb \& Arun Agrawal. "Does REDD+ Threaten to Recentralize Forest Governance?” (2010) (80) Science 312.

Pierson, Paul. "Not Just What, but When: Timing and Sequence in Political Processes" (2000) 14 Studies in American Political Development 72.

Pistorius, Till. "From RED to REDD+: The Evolution of A Forest-Based Mitigation Approach for Developing Countries" (2012) 4: 6 Current Opinion in Environmental Sustainability 638.

Polletta, Francesca. "The Structural Context of Novel Rights Claims: Southern Civil Rights Organizing, 1961-1966” (2000) 34: 2 Law ङ Society Review 367.

Price, Richard. "Reversing the Gun Sights: Transnational Civil Society Targets Land Mines” (1998) 52: 3 International Organization 613.

Rae, Jessica, Mahala Gunther \& Lee Godden. "Governing Tropical Forests: REDD+, Certification and Local Forest Outcomes" (2011) 7: 2 Macquarie Journal of International \& Comparative Environmental Law 40.

Rajamani, Lavanya. "The Increasing Currency and Relevance of Rights-Based Perspectives in the International Negotiations on Climate Change" (2010) 22: 3 Journal of Environmental Law 391.

Rantala, Salla \& Monica Di Gregorio. "Multistakeholder Environmental Governance in Action: REDD+ Discourse Coalitions in Tanzania” (2014) 19: 2 Ecology \& Society article 66.

Reed, Pablo. "REDD+ and the Indigenous Question: A Case Study from Ecuador" (2011) 2: 2 Forests 525.

Reinecke, Sabine, Till Pistorius \& Michael Pregernig. "UNFCCC and the REDD+ Partnership from a Networked Governance Perspective" (2014) 35 Environmental Science \& Policy 30.

Resosudarmo, Ida Aju Pradnja et al. "Does Tenure Security Lead to REDD+ Project Effectiveness? Reflections from Five Emerging Sites in Indonesia” (2014) 55 World Development 68.

Ribot, Jesse \& Anne M. Larson. "Reducing REDD Risks: Affirmative Policy on an Uneven Playing Field" (2012) 6: 2 International Journal of the Commons 233.

Risse, Thomas. “Let's Argue!': Communicative Action in World Politics” (2000) 54: 1 International Organization 1. 
Rodrigues de Aquino, André, André Aasrud \& Leticia Guimarães. "Can Forest Carbon Finance Influence Land Tenure Security in Project Areas? Preliminary Lessons from Projects in Niger and Kenya" (2011) 8 Advances in Agroforestry 231.

Roht-Arriaza, Naomi. "Human Rights in the Climate Change Regime" (2010) 1: 2 Journal of Human Rights and the Environment 211.

Sandbrook, Chris, Fred Nelson, William M. Adams \& Arun Agrawal. "Carbon, Forests and the REDD Paradox" (2010) 44: 03 Oryx 330.

Sanmukri, Miriam Harjati. "Mobilities of Indigeneity: Intermediary NGOs and Indigenous Peoples in Indonesia" (2013) 7 Göttingen Studies in Cultural Property 115.

Sarfaty, Galit A. "Why Culture Matters in International Institutions: The Marginality of Human Rights at the World Bank" (2009) 103 American 647.

Savaresi, Annalisa. "REDD+ and Human Rights: Addressing Synergies between International Regimes" (2013) 18: 3 Ecology and Society Art. 5.

"The Human Rights Dimension of REDD" (2012) 21: 2 Review of European Community \& International Environmental Law 102.

Schlamadinger, Bernhard et al. "A Synopsis of Land Use, Land-Use Change and Forestry (LULUCF) under the Kyoto Protocol and Marrakech Accords” (2007) 10: 4 Environmental Science \& Policy 271.

Schroeder, Heike \& Constance McDermott. "Beyond Carbon: Enabling Justice and Equity in REDD+ Across Levels of Governance" (2014) 19: 1 Ecology E Society 31.

Schwarte, Christoph. "Social Safeguards in REDD: A Review of Possible Mechanisms to Protect the Rights and Interests of Indigenous and Forest-Dependent Communities in a Future System for REDD” (2010) 6: 1 McGill Journal of Sustainable Development Law \& Policy 57.

Shaffer, Gregory. "Transnational Legal Process and State Change" (2012) 37: 2 Law \& Social Inquiry 229.

Shankland, Alex \& Leonardo Hasenclever. "Indigenous Peoples and the Regulation of REDD+ in Brazil: Beyond the War of the Worlds ?" (2011) 42: 3 IDS Bulletin 80.

Sikkink, Kathryn. "Transnational Politics, International Relations Theory, and Human Rights" (1998) 31: 3 Political Science and Politics 517.

Sikor, Thomas et al. "REDD-plus, Forest People's Rights and Nested Climate Governance" (2010) 20: 3 Global Environmental Change 423.

Simmons, Beth A. "Compliance with International Agreements" (1998) 1: 1 Annual Review of Political Science 75.

"International Law and State Behavior: Commitment and Compliance in International Monetary Affairs" (2000) 94: 4 American Political Science Review 819.

Somorin, Olufunso A. et al. "The Congo Basin Forests in a Changing Climate: Policy Discourses on Adaptation and Mitigation (REDD+)" (2012) 22: 1 Global Environmental Change 288.

Stone, Diane. "Transfer and Translation of Policy" (2012) 33: 6 Policy Studies 1.

Stone Sweet, Alec. "Judicialization and the Construction of Governance" (1999) 32: 2 Comparative Political Studies 147.

Streck, Charlotte. "Reducing Emissions from Deforestation and Forest Degradation: National Implementation of REDD Schemes - an Editorial Comment" (2010) 3-4 Climatic Change 389 . 
Street, Paul. "Stabilizing Flows in the Legal Field: Illusions of Permanence, Intellectual Property Rights and the Transnationalization of Law" (2003) 3: 1 Global Networks 7.

Sunderlin, William D. et al. "How Are REDD+ Proponents Addressing Tenure Problems? Evidence from Brazil, Cameroon, Tanzania, Indonesia, and Vietnam" (2014) 55 World Development 37.

Takacs, David. "Environmental Democracy and Forest Carbon (REDD+)" (2014) 44 Environmental Law 71.

Tansey, Oisín. "Process Tracing and Elite Interviewing: A Case for Non-probability Sampling" (2007) 40: 4 PS: Political Science \& Politics 765.

Thompson, Mary C., Manali Baruah \& Edward R. Carr. "Seeing REDD + as a Project of Environmental Governance” (2011) 14: 2 Environmental Science ๒ Policy 100.

Twining, William. "Diffusion of Law: A Global Perspective" (2004) 49 Journal of Legal Pluralism \& Unofficial Law 1.

Vanhala, Lisa. "The Diffusion of Disability Rights in Europe" (2015) 37: 4 Human Rights Quarterly 831.

Visseren-Hamakers, Ingrid et al. "Interdisciplinary Perspectives on REDD + Editorial Overview" (2012) 4 Current Opinion in Environmental Sustainability 1.

Wallbott, Linda. "Indigenous Peoples in UN REDD+ Negotiations: 'Importing Power' and Lobbying for Rights through Discursive Interplay Management" (2014) 19: 1 Ecology \& Society, art. 21.

Wendt, Alexander. "Anarchy Is What States Make of It: The Social Construction of Power Politics" (1992) 46 International Organization 391.

Willem den Besten, Jan, Bas Arts \& Patrick Verkooijen. "The Evolution of REDD+: An Analysis of Discursive-Institutional Dynamics" (2014) 35 Environmental Science \& Policy 40.

\section{MONOGRAPHS}

Allen, Stephen \& Alexandra Xanthaki, eds. Reflections on the UN Declaration on the Rights of Indigenous Peoples (Portland, Oregon: Hart Publishing, 2011).

Barume, Albert Kwokwo. Land Rights of Indigenous Peoples in Africa (Copenhagen, Denmark: IWGIA, 2010).

Beach, Derek \& Rasmus Brun Pedersen. Process-Tracing Methods: Foundations and Guidelines (Ann Arbor, Michigan: University of Michigan Press, 2013).

Berger, Peter \& Thomas Luckmann. The Social Construction of Reality (London, UK: Penguin Books, 1996).

Böhm, Steffen \& Siddhartha Dabhi, eds. Upsetting the Offset. The Political Economy of Carbon Markets (San Francisco, CA: Zed Books, 2009).

Brunée, Jutta \& Stephen Toope. Legitimacy and Legality in International Law. An Interactional Account (Cambridge, UK: Cambridge University Press, 2010).

Calliess, Gralf-Peter \& Peer Zumbansen. Rough Consensus and Running Code: A Theory of Transnational Private Law (Oxford: Hart Publishing, 2010).

Campbell, John. Institutional Change and Globalization (Oxford, UK: Oxford University Press, 2004). 
Cotterrell, Roger. Law, Culture and Society. Legal Ideas in the Mirror of Social Theory (Aldershot, UK: Ashgate Press, 2006).

Deflem, Mathieu. Sociology of Law. Visions of a Scholarly Tradition (Cambridge, UK: Cambridge University Press, 2008).

Delmas-Marty. Mireille. Un pluralisme ordonné, Tome z Les forces imaginantes du droit (Paris, France; Seuil, 2006).

DeSombre, Elisabeth. Global Environmental Institutions (Abingdon, UK: Routledge, 2006).

DeWalt, Kathleen M. \& Billie R. DeWalt. Participant Observation: A Guide for Fieldworkers (Walnut Creek, CA: AltaMira Press, 2002).

Dezalay, Yves \& Bryant Garth. Dealing in Virtue: International Commercial Arbitration and the Construction of a Transnational Legal Order (Chicago, IL: University of Chicago Press, 1996).

Engle Merry, Sally. Human Rights and Gender Violence: Translating International Law into Local Justice (Chicago: University of Chicago Press, 2006).

Espach, Ralph H. Private Environmental Regimes in Developing Countries. Globally Sown, Locally Grown (New York, NY: Palgrave Macmillan, 2009).

Finnemore, Martha \& Kathryn Sikkink. "International Norm Dynamics and Political Change" (1998) 52: 4 International Organization 887.

Finnemore, Martha. National Interests in International Society (Ithaca, NY: Cornell University Press, 1996).

Fox, Jonathan \& L. David Brown, eds. The Struggle for Accountability: The World Bank, NGOs and Grassroots Movements (Cambridge, MA: MIT Press, 1998).

George, Alexander \& Andrew Bennett. Case Studies and Theory Development in the Social Sciences (Cambridge, MA: MIT Press, 2005).

Goertz, Gary \& James Mahoney. A Tale of Two Cultures: Qualitative and Quantitative Research in the Social Sciences (Princeton, NJ: Princeton University Press, 2012).

Goodman, Ryan \& Derek Jinks. Socializing States. Promoting Human Rights through International Law (Oxford, UK: Oxford University Press, 2013).

Grawert, Elke. Departures from Post-Colonial Authoritarianism. Analysis of System Change with a Focus on Tanzania (Frankfurt, Germany: Peter Lang, 2009).

Gulbrandsen, Lars H. Transnational Environmental Governance. The Emergence and Effects of the Certification of Forests and Fisheries (Cheltenham, UK: Edward Elgar Press, 2010).

Hafner-Burton, Emilie. Forced to Be Good. Why Trade Agreements Boost Human Rights (Ithaca, NY: Cornell University Press, 2009).

Hall, Anthony. Forests and Climate Change. The Social Dimensions of REDD in Latin America (Cheltenham, UK: Edward Elgar, 2012).

Halliday, Terence \& Gregory Shaffer, eds. Transnational Legal Orders (Cambridge, UK: Cambridge University Press, 2015).

Halliday, Terence C \& Bruce Carruthers. Bankrupt: Global Lawmaking and Systematic Financial Crisis (Stanford, CA: Stanford University Press, 2009).

Hamm, Bridgitte. "A Human Rights Approach to Development" (2001) 23 Human Rights Quarterly 1005.

Katzenstein, Peter, ed. The Culture of National Security: Norms and Identity in World Politics (New York, NY: Columbia University Press, 1996). 
Keck, Margaret E. \& Kathryn Sikkink. Activists beyond Borders. Advocacy Networks in International Politics (Ithaca, NY: Cornell University Press, 1998).

Kollmuss, Anja, Helge Zink \& Clifford Polycarp. Making Sense of the Voluntary Carbon Market: A Comparison of Carbon Offset Standards (Berlin, Germany: WWF Germany).

Likosky, Michael B., ed. Transnational Legal Processes. Globalisation and Power Disparities (London, UK: Butterworths, 2002).

Lyster, Rosemary, Catherine McKenzie \& Constance K. McDermott. eds. Law, Tropical Forests and Carbon: The Case of REDD+ (Cambridge, UK: Cambridge University Press, 2013).

McAuslan, Patrick. Land Law Reform in East Africa. Traditional or Transformative? (Abingdon, UK: Routledge, 2009).

McCann, Michael. Rights at Work: Pay Equity Reform and the Politics of Legal Mobilization (Chicago, IL: University of Chicago Press, 1994).

McDermott, Constance L., Benjamin Cashore \& Peter Kanowski. Global Environmental Forest Policies: An International Comparison (London, England Earthscan, 2010).

Milledge, Simon, Ised Gelvas \& Anyje Ahrends. Forestry, Governance and National Development: Lessons, Learned from a Logging Boom in Southern Tanzania (TRAFFIC East/Southern Africa, 2007).

Morgan, Rhiannon. Transforming Law and Institution. Indigenous Peoples, the United Nations and Human Rights (Surrey, UK: Ashgate Press, 2011).

Onuf, Nicholas G. World of Our Making (Colombia, SC: University of South Carolina Press, 1989).

Orenstein, Mitchell A. Privatizing Pensions. The Transnational Campaign for Social Security Reform (Princeton, NJ: Princeton University Press, 2008).

Peluso, Nancy L. Rich Forests, Poor People: Resource Control and Resistance in Java (Berkeley, CA: Berkeley University Press, 1992).

Rayner, Jeremy, Alexander Buck \& Pia Katila, eds. Embracing Complexity: Meeting the Challenges of International Forest Governance (Vienna, Austria, 2010).

Risse, Thomas, Stephen C. Ropp \& Kathryn Sikkink, eds. The Persistent Power of Human Rights. From Commitment to Compliance (Cambridge, UK: Cambridge University Press, 2013).

Sandholtz, Wayne \& Kendall Stiles. International Norms and Cycles of Change (Oxford, UK: Oxford University Press, 2009).

Sarfaty, Galit A. Values in Translation: Human Rights and the Culture of the World Bank (Stanford, CA: Stanford University Press, 2012).

Schiff Berman, Paul. Global Legal Pluralism. A Jurisprudence of Law beyond Borders (Cambridge, UK: Cambridge University Press, 2007).

Seymour, Frances \& Arild Angelsen. "Summary and Conclusions REDD+ without Regrets" in Arild Angelsen et al., eds., Analysing REDD+. Challenges and Choices (Bogor Barat, Indonesia: CIFOR, 2012) 317.

Sil, Rudra \& Peter J. Katzenstein. Beyond Paradigms: Analytical Eclectecism in the Study of World Politics (Basingstoke, UK: Palgrave MacMillan, 2010).

Simmons, Beth A. Mobilizing for Human Rights: International Law in Domestic Politics (Cambridge: Cambridge University Press, 2010). 
Skutsch, Margaret ed. Community Forest Monitoring for the Carbon Market: Opportunities Under REDD (London, UK, Earthscan, 2011).

Stevens, Caleb et al. Securing Rights, Combating Climate Change. How Strengthening Community Forest Rights Mitigates Climate Change (Washington, DC: Rights \& Resources Institute, 2012).

Stone Sweet, Alec. Governing with Judges: Constitutional Politics in Europe (Oxford, UK: Oxford University Press, 2000).

Szablowski, David. Transnational Law and Local Struggles. Mining, Communities and the World Bank (Oxford, UK: Hart Publishing, 2007).

Tyson, Adam D. Decentralization and Adat Revivalism in Indonesia. The Politics of Becoming Indigenous (Abingdon, UK: Routledge, 2010).

Voigt, Christina, ed. Research Handbook on REDD-plus and International Law (Cheltenham, UK: Edward Elgar, 2016).

Von Daniels, Detlef. The Concept of Law from a Transnational Perspective (Burlington, VT: Ashgate Publishing, 2010).

Watson, Alan. Legal Transplants (Athens, GA.: University of Georgia Press, 1993).

Xanthaki, Alexandra. Indigenous Rights and United Nations Standards: SelfDetermination, Culture and Land (Cambridge, Cambridge University Press, 2007).

Youngblood Henderson, James. Indigenous Diplomacy and the Rights of Peoples: Achieving UN Recognition (Saskatoon, Saskatchewan: Purich Publishing, 2008).

\section{BOOK CHAPTERS}

Anandi, Cut Augusta Mindry et al. "TNC's initiative within the Berau Forest Carbon Program, East Kalimantan, Indonesia” in Erin O. Sills et al., eds., REDD+ on the Ground. A Casebook of Subnational Initiatives across the Globe (Bogor Barat, Indonesia: CIFOR, 2014) 362.

"Ulu Masen REDD+ Initiative, Aceh, Indonesia" in Erin O. Sills et al., eds., REDD+ on the Ground. A Casebook of Subnational Initiatives across the Globe (Bogor Barat, Indonesia: CIFOR, 2014) 380.

Anderson, Patrick \& Marcus Colchester. "Local Forest Governance, Free, Prior and Informed Consent and REDD+ in Indonesia: A Case Study from Aceh, Sumatra" in Holly Jonas, Harry Jonas \& Suneetha M. Subramanian, eds., The Right to Responsibility: Resisting and Engaging Development, Conservation, and the Law in Asia (Natural Justice and the United Nations University, 2013) 176.

Angelsen, Arild \& Desmond McNeill. "The evolution of REDD+" in Arild Angelsen et al., eds., Analysing REDD+. Challenges and Choices (Bogor Barat, Indonesia: CIFOR, 2012) 31.

Angelsen, Arild. "Policy Options to Reduce Deforestation" in Arild Angelsen et al., eds., Analysing REDD+. Challenges and Choices (Bogor Barat, Indonesia: CIFOR, 2012) 125 .

Asselt, Harro van \& Constance L. McDermott. "The Institutional Complex for REDD+: a 'benevolent jigsaw'?" in Christina Voigt, ed., Research Handbook on REDD-plus and International Law (Cheltenham, UK: Edward Elgar, 2016) 63. 
Bamba, John. "Recognition 'In Kind': Indonesian Indigenous Peoples and State Legislation" in Christian Erni, ed., The Concept of Indigenous Peoples in Asia. A Resource Book (Copenhagen, Denmark: IWGIA, 2008) 257.

Bastos Lima, Mairon, Joyeeta Gupta, Nicolien van der Grijp \& Fahmuddin Agus. "Case Study. Indonesia" in Joyeeta Gupta, Nicolien van der Grijp \& Onno Kuik, eds., Climate Change, Forests and REDD: Lessons for Institutional Design (Abingdon, UK: Routledge, 2013) 121.

Bodansky, Daniel. "Climate Change: Transnational Legal Order or Disorder?" in Terence Halliday \& Gregory Shaffer, eds., Transnational Legal Orders (Cambridge, UK: Cambridge University Press, 2015) 287.

Boisson de Chazournes, Laurence. "Policy Guidance and Compliance: The World Bank Operational Standards" in Dinah Shelton, ed., Commitment and Compliance. The Role of Non-Binding Norms in the International Legal System (Oxford, UK: Oxford University Press, 2000) 281.

Bozzi, Laura et al. "The Role of Climate Private Voluntary Programs Affecting Forests: Assessing Their Direct and Intersecting Effects" in Business and Climate Policy: The Potentials and Pitfalls of Private Voluntary Programs (Tokyo, Japan, United Nations University Press, 2012) 113.

Brütsch, Christian \& Dirk Lehmkuhl. "Introduction" in Christian Brüutsch \& Dirk Lehmkuhl, eds., Law and Legalization in Transnational Relations (Abingdon, UK: Routledge, 2007) 1.

Checkel, Jeffrey T. "Process Tracing" in Audie Klotz \& Deepa Prakash, eds., Qualitative Methods in International Relations. A Pluralist Guide (New York, NY: Palgrave Macmillan, 2008) 114.

Cohen, Edward S. "The Harmonization of Private Commercial Law. The Case of Secured Finance" in Christian Brüutsch \& Dirk Lehmkuhl, eds., Law and Legalization in Transnational Relations (Abingdon, UK: Routledge, 2007) 58.

Fischer, Robert \& Rosemary Lyster. "Land and Resource Tenure: The Rights of Indigenous Peoples and Forest Dwellers" in Rosemary Lyster, Catherine Mckenzie \& Constance K. McDermott, eds., Law, Tropical Forests and Carbon: The Case of REDD+ (Cambridge, UK: Cambridge University Press, 2013) 187 .

Forsyth, Tim. "Multilevel, Multiactor Governance in REDD+ Participation, Integration and Coordination" in Arild Angelsen et al., eds., Analysing REDD+. Challenges and Choices (Bogor Barat, Indonesia: CIFOR, 2012) 113.

Gilardi, Fabrizio. "Transnational Diffusion: Norms, Ideas, and Policies" in Walter Carlsnaes, Thomas Risse \& Beth A. Simmons, eds., Handbook of International Relations (London, UK: Sage Publications, 2013) 453.

Gomera, Maxwell, Liz Rihoy \& Fred Nelson. "A Changing Climate for Community Resource Governance: Threats and Opportunities from Climate Change and the Emerging Carbon Market" in Fred Nelson, eds, Community Rights, Conservation and Contested Land: The Politics of National Resource Governance in Africa (London, UK: Earthscan, 2010) 293.

Gover, Kirsty. "REDD+, Tenure, and Indigenous Property: The Promise and Peril of a Human Rights-Based Approach" in Christina Voigt, ed., Research Handbook on REDD-plus and International Law (Cheltenham, UK: Edward Elgar, 2016) 249 . 
Gusterson, Hugh. "Ethnographic Research" in Audie Klotz \& Deepa Prakash, eds., Qualitative Methods in International Relations. A Pluralist Guide (New York, NY: Palgrave Macmillan, 2008) 93.

Hall, Peter. "Historical Institutionalism in Rationalist and Sociological Perspective" in James Mahoney \& Kathleen Thelen, eds., Explaining Institutional Change: Ambiguity, Agency, and Power (Cambridge, UK: Cambridge University Press, 2009) 204 .

Hawkins, Slayde. "Legal Guidance: Legal and Contractual Aspects of Forest Carbon Projects" in Johannes Ebeling \& Jacob Olander, eds., Building Forest Carbon Projects. Step-by-Step Overview and Guide (Washington, DC: Forest Trends, 2011).

Henley, David \& Jamie S. Davidson. "Introduction" in Jamie S. Davidson \& David Henley, The Revival of Tradition in Indonesian Politics: The Deployment of Adat from Colonialism to Indigenism (Abingdon, UK: Routledge, 2007) 1.

Herold, Martin \& Margaret M. Skutsch. "Measurement, Reporting and Verification for REDD+: Objectives, Capacities and Institutions" in Arild Angelsen, ed., Realising REDD+. National Strategy and Policy Options (Bogor, Indonesia: CIFOR, 2009) 85 .

Indriatmoko, Yayan et al. "Katingan Peatland Restoration and Conservation Project, Central Kalimantan, Indonesia," in Erin O Sills et al., eds., REDD+ on the Ground. A Casebook of Subnational Initiatives across the Globe (Bogor Barat, Indonesia: CIFOR, 2014) 309.

Indriatmoko, Yayan et al. "Rimba Raya Biodiversity Reserve Initiative, Central Kalimantan, Indonesia” in Erin O Sills et al., eds., REDD+ on the Ground. A Casebook of Subnational Initiatives across the Globe (Bogor Barat, Indonesia: CIFOR, 2014) 348.

Jagger, Pamela, Stibniati Atmadja, Subhrendu K. Pattanayak, Erin Sills \& William D. Sunderlin. "Learning While Doing. Evaluating Impacts of REDD+ Projects" in Arild Angelsen, ed., Realising REDD+. National Strategy and Policy Options (Bogor, Indonesia: CIFOR, 2009) 281.

Jetschke, Anja \& Andrea Liese. "The Power of Human Rights a Decade after: From Euphoria to Contestation" in Thomas Risse, Stephen C. Ropp \& Kathryn Sikkink, eds., The Persistent Power of Human Rights. From Commitment to Compliance (Cambridge, UK: Cambridge University Press, 2013) 26.

Jodoin, Sébastien. "The Human Rights of Indigenous Peoples and Forest-Dependent Communities in the Complex Legal Framework for REDD+" in Christina Voigt, ed., Research Handbook on REDD-plus and International Law (Cheltenham, UK: Edward Elgar, 2016) 157.

Kingsbury, Benedict. "Operational Policies of International Institutions as Part of the Law-Making Process: The World Bank and Indigenous Peoples" in Guy S. Goodwin-Gill \& Stefan Talmon, eds., The Reality of International Law: Essays in Honour of Ian Brownlie (Oxford: Clarendon Press, 1999) 323.

Klotz, Audie. "Case Selection" in Audie Klotz \& Deepa Prakash, eds., Qualitative Methods in International Relations. A Pluralist Guide (New York, NY: Palgrave Macmillan, 2008) 43.

Likosky, Michael B. "Editor's Introduction: Transnational Law in the Context of Power Disparities," in Michael B. Likosky, eds., Transnational Legal Processes. Globalisation and Power Disparities (London, UK: Butterworths, 2002). 
Lloyd, Paulette \& Beth A. Simmons. "Framing for a New Transnational Legal Order: The Case of Human Trafficking" in Terence Halliday \& Gregory Shaffer, eds., Transnational Legal Orders (Cambridge, UK: Cambridge University Press, 2015) 400.

McAdam, Doug. "Conceptual Origins, Current Problems, Future Directions" in Doug McAdam, John D. McCarthy \& Mayer N. Zald, eds., Comparative Perspectives on Social Movements: Political Opportunities, Mobilizing Structures and Cultural Framing (Cambridge, UK: Cambridge University Press, 1996) 23.

Moeliono, Moira \& Ahmad Dermawan. "The Impact of Decentralization on Tenure and Livelihoods" in Christopher Barr et al., eds., Decentralization of Forest Administration in Indonesia: Implications for Forest Sustainability, Economic Development and Community Livelihoods (Bogor, Indonesia: CIFOR, 2006) 108.

Moniaga, Sandra. "From Bumiputera to Masyarakat Adat. A Long and Confusing Journey" in Jamie S. Davidson \& David Henley, The Revival of Tradition in Indonesian Politics: The Deployment of Adat from Colonialism to Indigenism (Abingdon, UK: Routledge, 2007) 275.

Nelson, Fred \& Tom Blomley. "Peasants' Forests and the King's Game? Institutional Divergence and Convergence in Tanzania's Forestry and Wildlife Sectors" in Fred Nelson, ed., Community Rights, Conservation and Contested Land: The Politics of Natural Resource Governance in Africa (Abingdon, UK: Routledge, 2012) 79 .

Nelson, Fred et al. "Community-Based Conservation and Maasai Livelihoods in Tanzania" in Katherine Homewood et al., Staying Maasai? Livelihoods, Conservation and Development in East African Rangelands (New York, NY: Springer, 2009) 299.

Pedroni, Lucio. Manuel Estrada Porrua \& Mariano Colini Cenamo. "The "Nested Approach' to REDD+: How Could it Be Implemented?” in Xianli Zhu et al., eds., Pathways for Implementing REDD+. Experiences from Carbon Markets and Communities (Nairobi, Kenya: UNEP, 2010) 89.

Peskett, Leo. "REDD+ and Development" in Rosemary Lyster, Catherine Mckenzie \& Constance K. McDermott, eds., Law, Tropical Forests and Carbon: The Case of REDD+ (Cambridge, UK: Cambridge University Press, 2013) 230.

Potoski, Matthew \& Aseem Prakash. "A Club Theory Approach to Voluntary Programs" in Matthew Potoski \& Aseem Prakash, eds., Voluntary Programs. A Club Theory Approach (Cambridge, MA: MIT Press, 2006) 17.

Risse, Thomas \& Kathryn Sikkink. "The Socialization of International Human Rights Norms into Domestic Politics: Introduction,” in Thomas Risse, Stephen C. Ropp \& Kathryn Sikkink, eds., The Power of Human Rights. International Norms and Domestic Change (Cambridge, UK: Cambridge University Press, 1999) 1.

Risse, Thomas \& Stephen C. Ropp. "Introduction and Overview" in Thomas Risse, Stephen C. Ropp \& Kathryn Sikkink, eds., The Persistent Power of Human Rights. From Commitment to Compliance (Cambridge, UK: Cambridge University Press, 2013) 3 .

Savaresi, Analisa, "The Legal Status and Role of Safeguards" in Christina Voigt, ed., Research Handbook on REDD-plus and International Law (Cheltenham, UK: Edward Elgar, 2016) 126. 
Seymour, Frances \& Arild Angelsen. "Summary and Conclusions: REDD Wine in Old Wineskins?" in Arild Angelsen, ed., Realising REDD+. National Strategy and Policy Options (Bogor, Indonesia: CIFOR, 2009) 293.

Seymour, Frances. "Forests, Climate Change and Human Rights: Managing Risks and Trade-Offs" in Stephen Humphreys, ed., Human Rights and Climate Change (Cambridge, UK: Cambridge University Press, 2009) 207.

Sikor, Thomas \& Johannes Stahl. "Introduction: The Rights-Based Agenda in International Forestry" in Thomas Sikor \& Johannes Stahl, eds., Forests and People. Property, Governance, and Human Rights (London, UK: Earthscan, 2011) 1. Sikor, Thomas. "REDD+. Justice Effects of Technical Design" in Thomas Sikor, ed., Justices and Injustices of Ecosystem Services (Abingdon, UK: Routledge, 2013) 46.

Sills, Erin, Erin Myers Madeira, William D. Sunderlin \& Sheila Wertz-Kanounnikoff. "The Evolving Landscape of REDD+ Projects" in Arild Angelsen et al., eds., Analysing REDD+. Challenges and Choices (Bogor Barat, Indonesia: CIFOR, 2012) 265 .

Simmons, Beth A. "From Ratification to Compliance: Quantitative Evidence on the Spiral Model" in Thomas Risse, Stephen C. Ropp \& Kathryn Sikkink, eds., The Persistent Power of Human Rights. From Commitment to Compliance (Cambridge, UK: Cambridge University Press, 2013) 43.

Snidal, Duncan. "Rational Choice and International Relations" in Walter Carlsnaes, Thomas Risse \& Beth A. Simmons, eds., Handbook of International Relations (London, UK: Sage Publications, 2013) 85.

Sunderlin, William D. "The Global Forest Tenure Transition: Background, Substance, and Prospects" in Thomas Sikor \& Johannes Stahl, eds., Forests and People. Property, Governance, and Human Rights (London, UK: Earthscan, 2011) 19.

Veit, Peter G., Darryl Vhugen \& Jonathan Mine. "Threats to Village Land in Tanzania Implications for REDD+ Benefit-Sharing Arrangements" in Lisa NaughtonTreves \& Cathy Day, eds., Lessons about Land Tenure, Forest Governance and REDD+. Case Studies from Africa, Asia and Latin America (Washington, DC: USAID, 2012) 11.

Wertz-Kanounnikoff, Sheila \& Arild Angelsen. "Global and National REDD+ Architecture Linking Institutions and Actions" in Arild Angelsen, ed., Realising REDD+. National Strategy and Policy Options (Bogor, Indonesia: CIFOR, 2009) 13.

Yusvita Intarin, Dian et al. "Ketapang Community Carbon Pools, West Kalimantan, Indonesia" in Erin O Sills et al., eds., REDD+ on the Ground. A Casebook of Subnational Initiatives across the Globe (Bogor Barat, Indonesia: CIFOR, 2014) 329.

Zahabu, Eliakimu \& Rogers E. Malimbwi. “The Potential of Community Forest Management under REDD+ for Achieving MDG Goals in Tanzania” in Margaret Skutsch, ed., Community Forest Monitoring for the Carbon Market: Opportunities Under REDD (London, UK, Earthscan, 2011) 134.

\section{NATIONAL LEGISLATION}

Basic Agrarian Law (Indonesia), Law 5/1960.

Basic Forestry Law (Indonesia), Law 5/1967.

Constitution of the Republic of Indonesia, 1945 (reinst. 1959, rev. 2002). 
Forest Act (Tanzania), Act No. 7 of 2002.

Land Act (Tanzania), Act No. 4 of 1999.

Village Land Act (Tanzania), Act No. 5 of 1999.

\section{GOVERNMENT DOCUMENTS}

Decision Number 35/PUU-X/2012, Constitutional Court of the Republic of Indonesia, 16 May 2013, available at: www.aman.or.id/wp-content/plugins/downloads-man ager/upload/constitutional_court_ruling_16_may_2013.pdf (accessed 7 January 2014).

Government of Brazil, Ministério do Meio Ambiente, "Plano de Prevenção e

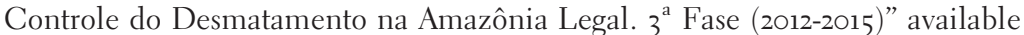
at: www.mma.gov.br/images/arquivo/80120/PPCDAm/_FINAL_PPCDAM.PD F (accessed 2 September 2014).

Government of Indonesia. Presidential Instruction no. 10/2011 Regarding Suspension of Granting of New Licenses and Improvement of Governance of Natural Primary Forest and Peat Land, available at : http://theredddesk.org/countries/policies/pre sidential-instruction-no-102011-regarding-suspension-granting-new-licenses-and (accessed 2 September 2014).

Government of Indonesia, Ministry of Forestry of the Republic of Indonesia, "Ministerial Regulation P. 20/Menhut-II/2012 on Implementation of Forest Carbon" available at: http://theredddesk.org/sites/default/files/ministerial_regu lation_on_implementation_of_forest_carbon_3.pdf (accessed 9 December 2014).

Memorandum of Understanding between the Government of the Cooperative Republic of Guyana and the Government of the Kingdom of Norway regarding Cooperation on Issues related to the Fight against Climate Change, the Protection of Biodiversity and the Enhancement of Sustainable Development (November 2009), available at: www.regjeringen.no/upload/md/vedlegg/klima/kli ma_skogprosjektet/the\%zomemorandum\%zoof\%zounderstanding\%zoguyana\%z onorway\%200n\%zoredd\%2o(081109)\%zosigned\%20091109.pdf (accessed 18 July 2014).

Ministério do Meio Ambiente. "Plano de Prevenção e Controle do Desmatamento na Amazônia Legal. $3^{a}$ Fase (2012-2015)" available at: www.mma.gov.br/images/arq uivo/8012o/ppcdam/_final_ppcdam.pdf (accessed 2 September 2014).

Ministry of Forestry of the Republic of Indonesia. "Ministerial Regulation P. 20/ Menhut-II/2O12 on Implementation of Forest Carbon" available at: http://there dddesk.org/sites/default/files/ministerial_regulation_on_implementation_of_for est_carbon_3.pdf (accessed 9 December 2014).

Norwegian Embassy. "Consolidated Comments to the Draft National REDD+ Strategy for Tanzania" 21 February 2011 (on file with the author).

Norwegian Ministry of Environment. Norwegian Climate Policy, Recommendation from the Ministry of the Environment, 25 April 2012, Approved by the Cabinet on the Same Date (Stoltenberg II Government), Report No. 21 to the Storting (20112012), available at: www.regjeringen.no/pages/38117723/pdfs/stm20112012002100oe n_pdfs.pdf (accessed 2 September 2014). 
Norwegian Ministry of Foreign Affairs. Climate, Conflict and Capital. Norwegian development policy adapting to change, Report No. 13 to the Storting (20082009), available at: www.regjeringen.no/pages/2171591/pdfs/stm200820090013000 en_pdfs.pdf (accessed 2 September 2014).

United Republic of Tanzania Vice-President's Office. Tanzania REDD+ Social and Environmental Standards. Final Draft (October 2013) (on file with the author).

United Republic of Tanzania Vice-President's Office. Tanzania REDD+ Social and Environmental Standards (June 2013) (on file with the author).

United Republic of Tanzania. "Forest Carbon Partnership Facility Readiness Preparation Proposal" (15 June 2010), available at: www.forestcarbonpartnership .org/sites/forestcarbonpartnership.org/files/Documents/PDF/Junzo1o/Tanzania-Revis ed_R-PP_main_document_V9-10.06.2010.pdf (accessed 9 October 2014).

United Republic of Tanzania. "Forest Carbon Partnership Facility Readiness Preparation Proposal: Annexes" (15 June 2010) available at: www.forestcarbonpart nership.org/sites/forestcarbonpartnership.org/files/documents/pdf/sep2o1o/tanza nia_r-pp_annexes\%20_august_2010.pdf (accessed 16 October 2014).

United Republic of Tanzania. Ministry of Natural Resources and Tourism, Forestry and Beekeeping Division, Community-Based Forest Management Guidelines for the Establishment of Village Land Forest Reserves and Community Forest Reserves (2007).

United Republic of Tanzania. Ministry of Natural Resources and Tourism, National Forest Policy, 1998.

United Republic of Tanzania. Ministry of Natural Resources and Tourism, Forestry and Beekeeping Division, National Forest Programme in Tanzania 2001-2010, 2001.

United Republic of Tanzania. Office of the Vice President, Draft National Strategy for the Reduction of Emissions from Deforestation and Forest Degradation (REDD+), (December 2010) (on file with the author).

United Republic of Tanzania. Office of the Vice President, National Strategy for Reducing Emissions from Deforestation and Forest Degradation, Second Draft (June 2012) (on file with the author).

United Republic of Tanzania. Office of the Vice President, National Framework for Reduced Emissions from Deforestation and Forest Degradation (REDD) (August 2009) (on file with the author).

United Republic of Tanzania. Office of the Vice President, National Strategy for Reduced Emissions from Deforestation and Forest Degradation (REDD+) (March 2013) (on file with the author).

United Republic of Tanzania. Office of the Vice-President, National Strategy for Growth and Reduction of Poverty, 2005.

\section{INTERNATIONAL MATERIALS}

"Report of the African Commission's Working Group of Experts on Indigenous Populations/Communities" Submitted in accordance with the "Resolution on the Rights of Indigenous Populations/Communities in Africa," adopted by The African Commission on Human and Peoples' Rights at its 28th ordinary 
session (Eks/Skolens Trykkeri and Copenhagen, Denmark: ACHPR and IWGIA, 2005).

ACHPR. "Concluding Observations and Recommendations on the Consolidated 2nd to 1oth Periodic Report of the United Republic of Tanzania," 43rd Ordinary Session, May 7-22 2008, Ezulwini, Kingdom of Swaziland, available at: www.achpr.org/files/sessions/43rd/conc-obs/2to10-1992-2008/achpr43_conc _staterep2to10_tanzania_2008_eng.pdf (accessed 6 February 2015).

African Commission on Human and Peoples Rights. Centre for Minority Rights Development (Kenya) and Minority Rights Group International on Behalf of Endorois Welfare Council (Case 276 / 2003), Judgement (2009).

Case of the Indigenous Community Yakye Axa v. Paraguay, Merits, Reparations and Costs, Judgment, Inter-Am. Ct. H.R. (ser. C) No. 125 (June 17, 2005).

Daes, Erica-Irene, Chairperson-Rapporteur, "Working Paper on the Concept of "indigenous people" (United Nations Economic and Social Council, 10 June 1996), UN Doc. E/CN.4/Sub.2/AC.4/1996/2.

Declaration on Environment and Development, Report of the United Nations Conference on Environment and Development, U.N. Doc. A/CONF.151/6/ Rev.1 (1992).

Human Rights Council, Working Group on the Universal Periodic Review. "Report of the Working Group on the Universal Periodic Review: United Republic of Tanzania" UN Doc. A/HRC/19/4 (2011).

Human Rights Council. Working Group on the Universal Periodic Review, "Summary prepared by the Office of the High Commissioner for Human Rights in accordance with paragraph 15 (c) of the annex to Human Rights Council resolution 5/1. United Republic of Tanzania" UN Doc. A/HRC/WG.6/12/TZA/3 (2011).

I/A Court H.R. Maya Indigenous Communities and Their Members against Belize (Case No. 12.053), Report No. 40/04, 12 October 2004.

Saramaka People v. Suriname, Preliminary Objections, Merits, Reparations, and Costs, Judgment of November 28, 2007, Series C No. 172.

Inter-American Court of Human Rights, 31 August 2001, Mayagna (Sumo) Awas Tingni Community v. Nicaragua, Series C, No. 79.

International Covenant on Civil and Political Rights, adopted 16 Dec. 1966, UNGA Res. 2200A (XXI), 21 U.N. GAOR Supp. (No. 16) at 52, U.N. Doc. A/6316 (1966), 999 U.N.T.S. 171, entered into force 23 Mar. 1976.

International Covenant on Civil and Political Rights, U.N. Doc. A/6316 (1966), entered into force 23 March 1976.

International Covenant on Economic, Social and Cultural Rights, adopted 16 Dec. 1966, UNGA Res. 2200A (XXI), 21 U.N. GAOR Supp. (No. 16) at 49, U.N. Doc. A/ 6316 (1966), 993 U.N.T.S. 3, entered into force 3 Jan. 1976.

Kyoto Protocol to the United Nations Framework Convention on Climate Change, 10 December 1997, 37 ILM 22 (1998), UN Doc. FCCC/CP/1997/7/Add.1, entered into force 16 February 2005.

Report of the Working Group on the Universal Periodic Review. UN Human Rights Council, 21st session (5 September 2012) UN Doc. A/HRC/21/7/Add.1.

South African Development Community, South African Development Community Protocol on Forestry (Luanda, 3 October 2002) entered into force 17 July 2009 . 
Submission by the Governments of Papua New Guinea \& Costa Rica, "Reducing Emissions from Deforestation in Developing Countries: Approaches to Stimulate Action" Eleventh Conference of the Parties to the UNFCCC: Agenda Item 6, available at: http://unfccc.int/resource/docs/2005/cop11/eng/misco1.pdf (accessed 21 May 2014).

UNFCCC COP, Decision 1/CP.13, "Bali Action Plan" in Report of the Conference of the Parties on its thirteenth session, Addendum, Part Two: Action taken by the Conference of the Parties at its thirteenth session, FCCC/CP/2007/6/Add.1 (14 March 2008).

Decision 1/CP.16, "The Cancun Agreements: Outcome of the work of the Ad Hoc Working Group on Long-Term Cooperative Action under the Convention" in Report of the Conference of the Parties on its sixteenth session, Addendum, Part Two: Action taken by the Conference of the Parties, FCCC/CP/2010/7/Add.1 (15 March 2011).

Decision 2/CP.13, "Reducing emissions from deforestation in developing countries: approaches to stimulate action" in Report of the Conference of the Parties on its thirteenth session, Addendum, Part Two: Action taken by the Conference of the Parties at its thirteenth session, FCCC/CP/2007/6/Add.1 (14 March 2008).

Decision 2/CP.17, UNFCCC COP, Decisions 9/CP.19, 10/CP.19, 11/CP.19, 12/CP.19, 13/CP.19, 14/CP.19 and 15/CP.19, in Report of the Conference of the Parties on its nineteenth session, held in Warsaw from 11 to 23 November 2013, FCCC/CP/2013/ 10/Add.1 (31 January 2014).

Decision 2/CP.17, "Outcome of the work of the Ad Hoc Working Group on Longterm Cooperative Action under the Convention" in Report of the Conference of the Parties on its sixteenth session, Addendum, Part Two: Action taken by the Conference of the Parties, FCCC/CP/2011/9/Add.1 (15 March 2012).

Decisions 9/CP.19, 10/CP.19, 11/CP.19, 12/CP.19, 13/CP.19, 14/CP.19 and 15/CP.19, in Report of the Conference of the Parties on its nineteenth session, held in Warsaw from 11 to 23 November 2013, FCCC/CP/2013/10/Add.1 (31 January 2014).

UNFCCC SBSTA. "Issues relating to indigenous people and local communities for the development and application of methodologies. Submissions from Parties. Addendum.” FCCC/SBSTA/2009/MISC.1.Add.1 (17 April 2009).

"Issues relating to indigenous people and local communities for the development and application of methodologies. Submissions from Parties. Addendum." FCCC/ SBSTA/2009/MISC.1.Add.2 (27 May 2009).

"Report on the expert meeting on guidance on systems for providing information on how safeguards for REDD-plus activities are addressed and respected" UN Doc. FCCC/SBSTA/2011/INF.17 (10 November 2011).

UNFCCC. Decision 12/CP.19, "The timing and the frequency of presentations of the summary of information on how all the safeguards referred to in decision 1/CP.16, appendix I, are being addressed and respected" FCCC/CP/2013/10/Add.1 (31 January 2014).

Decision 9/CP.19, "Work Programme on Results-Based Finance to Progress the Full Implementation of the Activities Referred to in Decision 1/CP.16, Paragraph 70" FCCC/CP/2013/10/Add.1 (31 January 2014).

United Nations Convention on Biological Diversity, adopted 5 Jun. 1992, 1760 U.N.T.S. 79, entered into force 29 Dec. 1992. 
United Nations Declaration on the Rights of Indigenous Peoples, U.N. Human Rights Council Resolution 2006/2, 13 September 2007, U.N. Doc. A/RES/61/295.

United Nations Framework Convention on Climate Change, 9 May 1992, 1771 U.N.T.S. 107, entered into force 21 March 1994, art. 4(1)(d).

Yanomami Indians v. Brazil, IACtHR Case 7615, OEA/ser. L/V/II.66, doc. 10 rev. 1 (1985), 1984-1985 Annual Report 24.

\section{NEWSPAPER AND MAGAZINE ARTICLES}

Gelling, Peter. "Indonesia Seeks Allies for Pay-for-Forests Plan" The New York Times, 28 October 2007.

\section{REPORTS}

Arnold, J.E.M. "Forests and people: 25 years of community forestry" (Rome, Italy: Food and Agriculture Organization of the United Nations, 2001), available at www.treesforlife.info/fao/docs/p/25y.pdf.

Baastel \& NORDECO. First Program Evaluation for the Forest Carbon Partnership Facility (FCPF). Evaluation Commissioned by the Participants Committee of the FPCF (June 2011), available at: www.forestcarbonpartnership.org/sites/forestcar bonpartnership.org/files/documents/pdf/junzo11/5.\%2ofinal\% zofcpf_evaluation _report_june\%2013th.pdf (accessed 27 September 2014).

Blomley, Tom \& Said Iddi. "Participatory Forest Management. 1993-2009. Lessons learned and experiences to date" (United Republic of Tanzania, Ministry of Natural Resources and Tourism, Forestry and Beekeeping Division, 2009), available at: www.tzonline.org/pdf/participatoryforestmanagement20o9.pdf (accessed 8 October 2014).

Campese, Jessica. "Integrating REDD+ Social and Environmental Safeguards and Standards in Tanzania" TFCG Technical Report 32, July 2011 (on file with author).

Deloitte. Mid-term Review Report of Nine NGO REDD+ Pilot Projects in Tanzania Higher-Level Overview of NGO REDD+Portfolio (17 August 2012) (on file with the author).

FAO. State of the World's Forests (Rome, Italy: FAO, 2011).

Godfrey Wood, Rachel. "Carbon finance and pro-poor co-benefits: The Gold Standard and Climate, Community and Biodiversity Standards" (London, UK: IIED, 2011).

Hamrick, Kelley et al. Ahead of the Curve: State of the Voluntary Carbon Markets 2015 (Washington, DC: Ecosystem Marketplace, 2015).

Kollmuss, Anja, Helge Zink \& Clifford Polycarp. Making Sense of the Voluntary Carbon Market: A Comparison of Carbon Offset Standards (Berlin, Germany: WWF Germany).

Mäkelä, Merja et al. "Lessons learned from the implementation of REDD Pilot Projects in Tanzania. 2009-2014" (NIRAS, July 2015) (on file with the author).

Nepstad, Daniel et al. Overview of Subnational Programs to Reduce Emissions from Deforestation and Forest Degradation (REDD) as Part of the Governors' 
Climate and Forests Task Force (Palto Alto, California: Electric Power Research Institute, 2012).

Peters-Stanley, Molly \& Gloria Gonzalez. Sharing the Stage. State of the Voluntary Carbon Markets 2014. Executive Summary (Washington, DC: Ecosystem Marketplace, 2014).

Peters-Stanley, Molly, Allie Goldstein \& Gloria Gonzalez. Turning over a New Leaf State of the Forest Carbon Markets 2014 (Washington, DC: Ecosystem Marketplace, 2013).

Peters-Stanley, Molly, Katherine Hamilton \& Daphne Yin. Leveraging the Landscape. State of the Forest Carbon Markets 2012 (Washington, DC: Ecosystem Marketplace, 2012).

PINGOs Forum. Annual Report. 2012-2013. Report Submitted to Oxfam Ireland (on file with the author).

Proforest. REDD+ SES Standards. Briefing on Complementarities with other REDD+ Social and Environmental Safeguards Mechanisms (Oxford, UK: Proforest, 2010).

Rogner, H-Holger et al. "Introduction" in Bert Metz et al., eds, Climate Change: The IPCC Scientific Assessment. Report of Working Group III to the Intergovernmental Panel on Climate Change: Mitigation of Climate Change available at: www.ipcc.ch /pdf/assessment-report/ar4/wg3/ar4-wg3-chapter1.pdf (2007).

UN-REDD Programme. Legal Analysis of Cross-Cutting Issues for REDD+ Implementation: Lessons Learned from Mexico, Viet Nam and Zambia (Geneva, Switzerland: UN-REDD Programme, 2013).

World Bank. Putting Tanzania's Hidden Economy to Work. Reform, Management, and Protection of its Natural Resource Sector (Washington, DC: World Bank, 2008).

\section{ELECTRONIC SOURCES}

Butler, Rhett. "Indonesia kills first-of-its-kind REDD+ Agency" (11 February 2015), available at: http://news.mongabay.com/2015/02/indonesia-dissolves-agency-char ged-with-forestry-reform/ (accessed 17 October 2015).

“Indigenous Peoples and Local Communities' Global Strategy on REDD” Adopted at the Global Indigenous Peoples Consultation on Reducing Emissions from Deforestation and Forest Degradation (REDD) on 14 November 2008, available at: www.unutki.org/default.php?doc_id=133 (accessed 13 September 2014).

Accra Caucus on Forests and Climate Change. "Accra Caucus Statement for COP 14" (December 2008), available at: http://unfccc.int/resource/docs/2008/smsn/ngo/o7 4.pdf (accessed 13 September 2014).

ALPA. "Achievements" available at: http://alapa.or.tz/alapa/?page_id=8 (accessed 20 October 2014).

AMAN \& Sawit Watch. "Indonesian Draft Readiness Plan, 16 October 2008” (15 May 2009), available at: www.forestcarbonpartnership.org/sites/forestcarbonpartner ship.org/files/aman_on_indonesia_r-plan_o.pdf (accessed 14 November 2014).

AMAN et al. "Saving Indonesia's Remaining Forests Can No Longer Be Delayed" available at: www.downtoearth-indonesia.org/sites/downtoearth-indonesia.org/fil es/call\%2oto\%zosave\%zoforests-final.pdf (accessed 18 November 2014). 
AMAN. "Profil Organisasi" available at: <http://www.aman.or.id/wp-content/plugins /downloads-manager/upload/profil_aman.pdf> (accessed 28 October 2014).

Australia, Argentina and Denmark. "Tanzanian R-PP External Review" available at: www.forestcarbonpartnership.org/sites/forestcarbonpartnership.org/files/docu ments/pdf/oct2o10/fcpf\%zoassessment\%2oof\%zotanzania's\%z r-pp\%zoconsolida ted\%2oaus-arg-dk\% zofinal.pdf (accessed 16 October 2014).

Caldecott, Julian et al. "Indonesia-Norway REDD+ Partnership - Second Verification of Deliverables. Final Report" (8 November 2013), available at: www.regjeringen .no/upload/kld/kl/klima-og-skogprosjektet/indonesianorwayreddsecondverifica tionfinalreport.pdf (accessed 10 November 2014).

CCB Standards Project Database. "MJUMITA Community Forest Project (Lindi)" available at: www.climate-standards.org/2014/05/08/mjumita-community-forest-p roject-lindi/ (accessed 4 November 2014).

CCBA. "CCB Standards 'Standards Committee' Composition” (15 January 2013), available at: https://sz.amazonaws.com/ccba/upload/revision+and+small/ccb+sta ndards+committee+composition+02-04-13.pdf (accessed 1 October 2014).

“Climate, Community \& Biodiversity Standards. Third Edition" (December 2013), available at: https://s3.amazonaws.com/ccba/third_edition/ccb_standards_third_e dition_december_2013.pdf (accessed 24 September 2014).

"Compilation by principle of all comments on the Draft Third Edition of the CCB Standards of 22nd March 2013 received during the first 6o-day public comment period 22nd March to 31st May 2013" (26 July 2013) available at: https://s3.amazo naws.com/ccba/upload/revision+and + small/second +comment+period $+\% 26+$ rul es/ccb+standards+third+edition+response+to +comments $+31 s t+j u l y+2013 \cdot p d f$ (accessed 1 October 2014).

"Projects" available at: www.climate-standards.org/category/projects/ (accessed 27 September 2014).

"Reducing Carbon Emissions from Deforestation in the Ulu Masen Ecosystem" available at: www.climate-standards.org/2007/11/o2/reducing-carbon-emissions-fr om-deforestation-in-the-ulu-masen-ecosystem/ (accessed 10 December 2014).

"Rimba Raya Biodiversity Reserve REDD Project" available at: www.climate-stan dards.org/2010/o6/o8/rimba-raya-biodiversity-reserve-redd-project/ (accessed 10 December 2014).

"Terms of reference, procedures and work plan for revision of CCB Standards including modifications that support smallholder- and community-led projects" (16 November 2012), available at: https://s3.amazonaws.com/ccba/upload/revision +and+small/tor+and+workplan+for+ccb+standards+revision+11-19-12.pdf (accessed 24 September 2014).

CCB Standards Third Edition, 2013, available at: https://s3.amazonaws.com/ccba/t hird_edition/ccb_standards_third_edition_december_2013.pdf.

Guidance for the Use of CCB Standards, available at: https://s3.amazonaws.com /ccba/guidance_for_the_use_of_the_ccb_standards_may_2013.pdf (accessed 24 September 2014).

Rules for the Use of the Climate, Community \& Biodiversity Standards, 2013, available at: https://sz.amazonaws.com/ccba/third_edition/rules_for_the_use_of_the_ccb _standards_december_2013.pdf (accessed 24 September 2014). 
CDM Executive Board. "Clean Development Mechanism Validation and Verification Manual" (Version o1.2), available at: https://cdm.unfccc.int/reference/standards laccr_mano1_2.pdf (accessed 16 September 2014).

Centre for Standardization and Environment, Pusat Standardisasi \& Dan Lingkunkan. Principles, Criteria and Indicators for a System for Providing Information on REDD+ Safeguards Implementation in Indonesia (Jakarta, March 2013), available at: www .staneclime.org/ (accessed 31 December 2013).

CIFOR. "Global database of REDD+ and other forest carbon projects Interactive map" available at: www.forestsclimatechange.org/redd-map/ (accessed 10 June 2014).

Climate Focus. "Focus Areas: REDD+" available at: www.climatefocus.com/pages/r edd_pluslts international (accessed 15 December 2013).

Climate, Community \& Biodiversity Alliance. "CCB Standards” available at: www.cl imate-standards.org/ccb-standards/ (accessed 22 July 2014).

Conservation International. "REDD+" available at: www.conservation.org/learn/cli mate/solutions/mitigation/pages/climate_redd.aspx (accessed 15 December 2013).

Declaration on Climate Change and Indigenous Peoples of El Salvador (CCNIS 2009), Indigenous Peoples' Global Summit on Climate Change, "The Anchorage Declaration" (24 April 2009), available at: http://unfccc.int/resource /docs/2009/smsn/ngo/168.pdf (accessed 13 September 2014).

FAD. "Update 2011 - Indonesia” available at: www.iwgia.org/regions/asia/indonesia/8 71-update-2011-indonesia (accessed 28 October 2014).

FAO, UNDP \& UNEP. UN Collaborative Programme on Reducing Emissions from Deforestation and Forest Degradation in Developing Countries Framework Document (20 June 2008), available at: www.un-redd.org/portals/15/documents/p ublications/un-redd_frameworkdocument.pdf (accessed 30 December 2013).

FCPF FMT. "Comments from the World Bank Team on Tanzania's R-PP" (version submitted in October 2010), available at: www.forestcarbonpartnership.org/sites /forestcarbonpartnership.org/files/documents/pdf/octzo10/world\%2obank\%2oco mments\%zoon\%zotz\% zor-pp.pdf.

FCPF PC. "Resolution PC/7/2010/1: Tanzania's Readiness Preparation Proposal" available at: www.forestcarbonpartnership.org/sites/forestcarbonpartnership.org /files/documents/pdf/nov2010/pc7\%2oresolutions.pdf (accessed 16 October 2014).

FCPF. "FCPF Dashboard: Revised May 30, 2014" available at: www.forestcarbonpart nership.org/sites/fcp/files/2014/june/fcpf\%_oreadiness\%zoprogress_june\%202_21 04.pdf (accessed 22 September 2014).

"Forest Carbon Partnership Facility. Information Memorandum" (18 June 2008), available at www.forestcarbonpartnership.org/sites/forestcarbonpartnership.or g/files/fcpf_info_memo_o6-13-08.pdf.

"Indonesia R-PLAN: Synthesis Review by FCPF Technical Advisory Panel" (2 June 2009), available at: www.forestcarbonpartnership.org/sites/forestcarbonpartnership .org/files/indonesia_r-plan_tap_synthesis_o6-2-o9.pdf (accessed 14 November 2014).

"Participants' Committee: Third Meeting (June 16-18, 2009, Montreux). PC Discussions of Indonesia's Readiness Preparation Proposal. Summary Report" available at: http://forestcarbonpartnership.org/sites/fcp/files/summary\%zoreport \%2or-pp\%zoindonesia\%zofinal.pdf (accessed 14 November 2014). 
"Readiness Preparation Proposal Assessment Note on a Proposed Grant in the Amount of US\$ 3.6 Million to the Republic of Indonesia for REDD+ Readiness Preparation Support" (3 February 2011) (on file with the author).

"REDD Readiness Progress Fact Sheet. Country: Tanzania. Marchzo14" available at: www.forestcarbonpartnership.org/sites/forestcarbonpartnership.org/files/docu ments/pdf/marzo12/redd\%zotanzania\%zofact\%2osheet_march\%202012_o.pdf (accessed 22 October 2014).

"REDD Readiness Progress Fact Sheet" available at: https://forestcarbonpartnership .org/sites/fcp/files/2014/august/fcpf\% zocountry\%zoprogress\%zofact\%zosheet\%zoa ugust\%202014-tanzania.pdf (accessed 7 October 2014).

"REDD Readiness Progress Sheet: Tanzania, March 2012" available at: www.forestcar bonpartnership.org/sites/forestcarbonpartnership.org/files/documents/pdf/marzo12/re dd\%2otanzania\%2ofact\%2osheet_march\%202012_o.pdf (accessed 14 October 2014).

"REDD Readiness Progress Sheet. Country: Indonesia" (October 2013) available at: http://forestcarbonpartnership.org/sites/fcp/files/2013/oct2013/indonesia\%2ofcpf\% zoredd\%2oreadiness\%2oprogress\%2ofact\%20sheet\%200ct\%202013.pdf (accessed 18 November 2014).

“Third Participants' Committee, June 16-18, 2009, Montreux, Switzerland. Resolution PC/3/2009/5 Indonesia Readiness Preparation Proposal." available at: http://forestcarbonpartnership.org/sites/fcp/files/resolution\% 205-\% 20r-pp-indone sia\% zofinal.pdf (accessed 14 November 2014).

Common Approach to Environmental and Social Safeguards for Multiple Delivery Partners (9 August 2012), available at: www.forestcarbonpartnership.org/sites/forest carbonpartnership.org/files/documents/pdf/augzol2/fcpf\%zoreadiness\% $\%$ ofund $\% 2$ ocommon\% 20approach\%208-9-12.pdf (accessed 30 December 2013).

Forest Carbon Partnership Facility (FCPF). "Capacity Building Program for ForestDependent People on REDD plus” (February 22, 2010), available at: www.forest carbonpartnership.org/sites/fcp/files/documents/tagged/fcpf_fmt_note_2010-8_i P_capacity_building_O2-22-10\%5b1\%5d.pdf (accessed 30 December 2013).

Forest Carbon Partnership Facility (FCPF). Sixth Meeting of the Participants Committee (PC6), June 28-July 1, 2010 - Georgetown, Guyana, Informal Summary of Discussions of Tanzania's Draft R-PP, available at: www.forestcar bonpartnership.org/sites/forestcarbonpartnership.org/files/documents/pdf/ju l2010/4asummary_pc6_discussion.pdf (accessed 9 October 2014).

Forest Peoples Programme. "Sumatra: Update on RAPP's Activities in the Kampar Peninsula, Riau," Rights, Forests and Climate Briefing Series (October 2011), available at: www.forestpeoples.org/sites/fpp/files/publication/2011/10/kampar-penin sula-briefing-5.pdf (accessed 4 December 2014).

Forest Trends. "REDDx - Indonesia" available at: http://reddx.forest-trends.org/coun try/indonesia/ (accessed 10 November 2014)

FPP. "Sawit Watch" available at: www.forestpeoples.org/partners/sawit-watch (accessed 18 November 2014).

Fréchette, Alain et al. "External Evaluation of the United Nations Collaborative Programme on Reducing Emissions from Deforestation and Forest Degradation in Developing Countries (the UN-REDD Programme)" available at: www.unep .org/eou/portals/52/reports/un-redd\%zoevaluation\%zofinal\%zoreport\%zojuly\%zo 2014\%20\%28eng\%29.pdf (accessed 28 November 2014). 
Gapare, Nelson \& Christopher William. "Final Evaluation of the UN-REDD Tanzania National Programme" 4 December 2013, available at: www.fao.org /fileadmin/user_upload/oed/docs/unjpurt238unj_2013_er.pdf (accessed 7 January 2014).

Independent Evaluation Group. The Forest Carbon Partnership Facility. Global Program Review (August 2012), available at: https://ieg.worldbankgroup.org/data /reports/fcpf_gpr.pdf (accessed 22 September 2014).

Institute for Global Environmental Strategies. "Indonesia REDD+ Readiness - State of Play” (November 2012), available at: http://redd-database.iges.or.jp/redd/down load/link?id=13 (accessed 21 November 2014).

"REDD+ Projects. A Review of Selected REDD+ Project Designs" (February 2013), available at: http://redd-database.iges.or.jp/redd/redd+_project_booklet_en.pdf (accessed 9 December 2014).

International Bank for Reconstruction and Development, Charter Establishing the Forest Carbon Partnership Facility (8 August 2013), available at: www.forestcarbon partnership.org/sites/fcp/files/2013/august2013/fcpf\%zocharter\%20-\%208-8-13\%20 clean.pdf (accessed 30 December 2013).

Accountability at the World Bank. The Inspection Panel at Fifteen Years (2009), available at: http://siteresources.worldbank.org/extinspectionpanel/resources/380 793-1254158345788/inspectionpanel2009.pdf (accessed 30 December 2013).

International Fund for Agricultural Development (IFAD). "Country Technical Note on Indigenous Peoples' Issues: The United Republic of Tanzania” (June 2012), available at: www.ifad.org/english/indigenous/pub/documents/tnotes/tanzania.pdf (accessed 8 October 2014).

Intervention by H.E. Dr. Susilo Bambang Yudhoyono, President of the Republic of Indonesia on Climate Change at the G-20 Leaders Summit, 25 September 2009, Pittsburgh, PA, available at: http://forestclimatecenter.org/files/2009\%9609-25\%2 ointervention \%zoby\%zopresident\%zosby $\%$ zoon\%zoclimate\%zochange\%zoat\%z othe\% zog-20\%zoleaders\%zosummit.pdf (accessed 9 September 2014).

IUCN. "IUCN REDD+ Project in Indonesia Supports Customary Land Mapping" available at: www.iucn.org/news_homepage/news_by_date/?13413/iucn-redd-pro ject-in-indonesia-supports-customary-land-mapping (accessed 7 January 2014).

Jacobs, Gerhard. “Tanzania sells Masai people's land to Arab royals, who want to build a hunting reserve for the rich" available at: www.thesouthafrican.com/ tanzania-sells-masai-peoples-land-to-arab-royals-who-want-to-build-a-hunting-reserv e-for-royals/ (accessed 19 December 2014).

Lang, Christopher. “No rights, no REDD': Indigenous Peoples protest in Poznan” REDD-Monitor, 9 December 2008, available at: www.redd-monitor.org/2008/12 log/no-rights-no-redd-indigenous-peoples-protest-in-poznan/ (accessed 1 August 2014).

"Interview with Bernadinus Steni, HuMa: 'REDD should be a way of supporting and strengthening the tenure of local communities and indigenous peoples that manage forests sustainably"' (17 April 2012), available at: www.redd-monitor.org /2012/04/17/interview-with-bernadinus-steni-huma/ (accessed 18 November 2014).

Lillegraven, Anja \& Rukka Sombolinggi. "Neither Cheap Nor Quick, but Critical" Development Today (26 March 2014), available at: www.development-today.com /magazine/2014/dt_3_2014/opinion (accessed 18 November 2014). 
LTS International. "Our Services: REDD+” available at: www.ltsi.co.uk/services/red d/ (accessed 15 December 2013);

McKinsey \& Co. "Carbon and Energy Economics" available at: www.mckinsey.com /client_service/sustainability/expertise/carbon_and_energy_economics (accessed 15 December 2013).

Multi-Partner Trust Fund Office. "UN-REDD Programme - Tanzania Quick Start Initiative" available at: http://mptf.undp.org/factsheet/project/o0073511 (accessed 6 January 2013).

National Taskforce for Developing the National REDD Strategy. "Guidelines for Review of NGOs/ CSOs Proposals to be funded by the Norway-Tanzania REDD Initiative" in United Republic of Tanzania, Office of the Vice President, National Framework for Reduced Emissions from Deforestation and Forest Degradation (REDD) (August 2009) (on file with the author).

NORAD. "Real-Time Evaluation of Norway's International Climate and Forest Initiative Contributions to National REDD + Processes 2007-2010 Country Report: Tanzania” (March 2011), available at: www.norad.no/en/tools-and-publi cations/publications/evaluations/publication/_attachment/333469?_download= true\&_ts=12fobe7412d (accessed 14 October 2014).

"Real-Time Evaluation of Norway's International Climate and Forest Initiative. Synthesising Report 2007-2013. Annexes 3-19. Report 3/2014" (August 2014), available at: www.norad.no/no/evaluering/publikasjoner/publikasjon/_attach ment/415168?_download=true\&_ts=147e976c97e (accessed 6 October 2014).

"Real-Time Evaluation of Norway's International Climate and Forest Initiative. Contributions to a Global REDD+ Regime 2007-2010" (April 2011), available at: www.norad.no/en/tools-and-publications/publications/publication/_attach ment/333465?_download=true\&_ts=12fgbe5d34b (accessed 19 November 2014).

"Real-Time Evaluation of Norway's International Climate and Forest Initiative Contributions to National REDD + Processes 2007-2010. Country Report: Indonesia" (March 2011), available at: www.norad.no/en/tools-and-publications /publications/publication/_attachment/333468?_download=true\&_ts=12f9be6f113 (accessed 6 October 2014).

Norwegian Ministry of Climate and the Environment. "How are the funds being spent?” available at: www.regjeringen.no/en/dep/kld/kampanjer/the-govern ments-climate-and-tree-project/how-are-the-funds-being-spent.html?id=734170 (accessed 18 July 2014).

"Who are our collaboration partners?" available at: www.regjeringen.no/en/dep/kld /kampanjer/the-governments-climate-and-tree-project/who-are-our-collaboration -partners.html?id=733948 (accessed 18 July 2014).

NIRAS Finland Oy, "Final Review of the Project- African Wildlife FoundationAdvancing REDD in the Kolo Hills forest" (June 2015) (on file with the author).

Ochieng Kojwang, Harrison and TAP Team. "Tanzanian R-PP External Review" available at: www.forestcarbonpartnership.org/sites/forestcarbonpartnership.org /files/documents/pdf/junzo1o/tanzania_r-pp_tap_review_synthesis.pdf (accessed 9 October 2014). 
Price Waterhouse Coopers. "Forest Carbon and REDD” available at: www.pwc.co.uk/su stainability-climate-change/issues/can-forests-help-to-solve-climate-challenges.jhtml (accessed 15 December 2013).

Rainforest Foundation Norway. "Supporting indigenous and forest-dependent peoples' interests" available at: www.norad.no/en/support/climate-and-forest-initiativ-sup port-scheme/grants-2009-2012/_attachment/407553?_ts=141ee889eze\&down load=true (accessed 16 December 2014).

Rainforest Foundation, UK. "The Accra Caucus on Forests and Climate Change" available at: www.rainforestfoundationuk.org/accra_caucus (accessed 13 September 2014).

Readiness Preparation Proposal Template Document, Version 6 (23 November 2011), available at : www.unredd.net/index.php?option=com_docman\&task=doc_down load\&gid=6869\&itemid=53 (accessed 30 December 2013), Annex 4.

REDD+ Desk, available at: http://theredddesk.org/countries/search-countries-database? $\mathrm{f}[\mathrm{o}]=$ type\%zalaw\&f[1]=field_primary_focal_area\%zaredd (accessed 2 September 2014).

REDD+ Safeguards Working Group. "What We Do" available at: http://reddplussafe guards.com ?page_id=103 (accessed 8 January 2014).

REDD+ Secretariat. "Tanzania REDD Initiative Newsletter" Issue 5, March 2011 (on file with the author).

REDD+ SES. "About the REDD+ SES" available at: www.redd-standards.org (accessed 15 December 2013).

"About the REDD+ SES" available at: www.redd-standards.org (accessed 24 September 2014).

"Country Overview" available at: www.redd-standards.org/index.php?option=com _content\&view=article\&id=16\&itemid=19 (accessed 24 September 2014).

"REDD+ Social \& Environmental Standards" Version 2, 10 September 2012, available at: www.redd-standards.org.

Guidelines for the Use of REDD+ Social \& Environmental Standards at Country Level, Version 2, 16th November 2012, available at: www.redd-standards.org/files /pdf/redd-docs/standards/redd_ses_guidelines_version_2_-_16_november_2012.pd $\mathrm{f}$ (accessed 30 December 2013).

Republic of Indonesia, Presidential Decree no 10/2011, "Suspension of Granting of New licenses and Improvement of Governance of Natural Primary Forest and Peatland" (May 2011), available at: www.unorcid.org/upload/doc_lib/2012111209o 818_goi\%20-\%2opresidential\%zoinstruction\%20no.\%2010\%202011\%2oregarding\% zosuspension\%zoof\%zogranting\% zoof\%zonew\%zolicenses\%zoand\% zoimprove ment $\%$ zoof\%zogovernance\% zoof\% zonatural\%zoprimary $\%$ zoforest $\%$ zoand $\%$ zope at\% zoland.pdf (accessed 10 November 2014).

"R-PLAN" (May 2009), available at: www.forestcarbonpartnership.org/sites/forest carbonpartnership.org/files/documents/pdf/marzo10/indonesia_rplan_mayzoo9 _with_disclaimer.pdf (accessed 14 November 2014).

Rights \& Resources Initiative. Seeing People through The Trees. Scaling Up Efforts to Advance Rights and Address Poverty, Conflict and Climate Change (2008) available at: www.rightsandresources.org/documents/files/doc_737.pdf (accessed 13 September 2014). 
Schalatek, Liane, Alice Caravani, Smita Nakhooda \& Charlene Watson. "Climate Finance Thematic Briefing: REDD+ Finance" available at: www.odi.org/sites /odi.org.uk/files/odi-assets/publications-opinion-files/7912.pdf (accessed 18 July 2014).

Smith, David. "Tanzania’s Masai ‘breathe sigh of relief after president vows never to evict them," available at: www.theguardian.com/world/2014/nov/25/tanzania-mas ai-eviction-uturn (accessed 19 December 2014).

Statement by H.E. Ambassador Ramadhan M. Mwinyi, Deputy Permanent Representative of the United Republic of Tanzania to the United Nations, during the 12th session of the Permanent Forum on Indigenous Issues, Agenda Item 4, "Half-Day Discussion on African Region" (New York, 23 May 2013), available at: www.minorityvoices.org/force_download.php?file=data/files/final/ne ws_1435/tanzaniagovernmentstatementtotheun.pdf (accessed 19 December 2014).

Steni, Bernadinus and Nadia Hadad. "REDD+ Safeguards in Indonesia" (HuMa and Bank Information Center, March 2012), available at: www.bicusa.org/wp-content /uploads/2013/oz/redd-indonesia-case-study.pdf (accessed 20 November 2014).

Tanzania Development Partners Group. “The Large and Uncaptured Potential of the Forestry Sector in Developing Tanzania’s Economy" (2005), available at: www.tzonline.org/pdf/thelargeanduncapturedpotentialoftheforestry.pdf (accessed 7 October 2014).

Tanzania Forest Conservation Group et al. "Recommendations from Tanzanian Civil Society with regard to Tanzania's Readiness Preparation Proposal to the Forest Carbon Partnership Facility" available at: www.forestcarbonpartner ship.org/sites/forestcarbonpartnership.org/files/documents/pdf/octzo10/pc\%203 c\%zotanzania\%zor-pp\%zocso\%zorecommendations.pdf (accessed 16 October 2014).

Tauli-Corpuz, Victoria. "International Human Rights Day 2008: a sad day for indigenous peoples" (10 December 2008), available at: www.forestpeoples.org/to pics/un-framework-convention-climate-change-unfccc/news/2011/o5/interna tional-human-rights-day-200 (accessed 13 September 2014).

Tebtebba. "Press Statement of Tebtebba: Assessment of What Indigenous Peoples Have Gained So Far in the Negotiations in Bonn 2" (11 June 2009) available at: www.tebtebba.org/index.php/all-resources/category/84-redd-and-ad-and-indigen ous-peoples?download=421:tebtebba-press-statement-on-the-bonn-climate-talks-11 -june-2009 (accessed 13 September 2014).

The Governor of Central Kalimantan. "Regulation of the Governor of the Province of Central Kalimantan Number 102012 regarding the Regional Strategy and Action Plan for Reducing Emissions from Deforestation and Forest Degradation - Plus in Central Kalimantan Province" available at: www.gcftaskforce.org/documents/central\%zokali mantan\%2ogovernor\%2oregulation_10_2012_en.pdf (accessed 2 September 2014).

The Jakarta Post. "Govt urged to pass bill on indigenous people's rights" (23 March 2014), available at: www.thejakartapost.com/news/2014/o3/23/govt-urged-pass-bill -indigenous-people-s-rights.html (accessed 17 December 2014).

The REDD+ Desk. "REDD Countries" available at: http://theredddesk.org/countries (accessed 24 November 2014).

The Samdhana Institute. "Nine Ministries-Institutions Agree to Launch National Programme for the Recognition and Protection of Customary Communities 
through REDD+” available at: www.samdhana.org/index.php/news-detail/nine -ministries-institutions-agree-to-launch-national-programme-for-the-recognitionand-protection-of-customary-communities-through-redd- (accessed 17 December 2014).

UN-REDD Programme News. “Indonesia’s National REDD+ Strategy: UN-REDD Indonesia Is Collaborating with the National Development Planning Agency (BAPPENAS) to Conduct an Intensive Multi-stakeholder Consultation Process That Will Produce the World's First Fully Participatory National REDD+ Strategy" (12 September 2010), available at: www.un-redd.org/newsletterı/indone sia_national_redd_strategy/tabid/5533/default.aspx (accessed 17 November 2014).

UN-REDD Programme. "Concept Note for Support to Community-Based REDD+" available at: www.unredd.net/index.php?option=com_docman\&task=doc_down load\&gid=10599\&itemid=53 (accessed 6 January 2014).

"Country Approach to Safeguards Tool (CAST). User's Guide" available at: www .unredd.net/index.php?option=com_docman\&task=doc_download\&gi $\mathrm{d}=12996 \&$ itemid $=53$ (accessed 28 November 2014).

"Country Approach to Safeguards Tool (CAST)" available at: www.unredd.net/ind ex.php?option $=$ com_docman \&task=doc_download\&gid $=12997 \&$ itemid $=53$ (accessed 28 November 2014).

"Draft Social and Environmental Principles and Criteria - Benefit and Risks Tool Using the SEPC" (2013), available at: www.unredd.net/index.php?option=com _docman\&task=doc_download\&gid=6380\&itemid=53 (accessed 28 November 2014).

"Guidelines on Free, Prior and Informed Consent" (January 2013), available at: www.unredd.net/index.php?option=com_docman\&task=doc_download \&gi $\mathrm{d}=8717 \&$ itemid=53 (accessed 7 January 2014).

"Guidelines on Stakeholder Engagement" available at: www.un-redd.org/stakehol der_engagement/guidelines_on_stakeholder_engagement/tabid/55619/default.as px (accessed 28 November 2014).

"Social and Environmental Principles and Criteria" UN-REDD Programme Eighth Policy Board Meeting (25-26 March 2012, Asunción, Paraguay), available at: www .unredd.net/index.php?option $=$ com_docman\&task=doc_download \&gid $=6754 \&$ itemid $=53$ (accessed 28 November 2014).

"The UN-REDD Programme Strategy. 2011-2015" available at: www.unep.org/forests /portals/142/docs/un-redd\%2oprogramme\%2ostrategy.pdf $>$ (accessed 28 November 2014).

"Update on Social and Environmental Principles" UN-REDD Programme $5^{\text {th }}$ Policy Board Meeting, November 2010, UN Doc. UNREDD/PBS/2010/12, available at: www.unredd.net/index.php?option $=$ com_docman\&task=doc_down load\&gid $=3554 \&$ itemid $=53$ (accessed 28 November 2014).

Report of the Tenth Policy Board Meeting, Lombok, Indonesia, FFFC26-27 June 2013 available at: www.unredd.net/index.php?option $=$ com_docman\&task=doc _download\&gid=10820\&itemid=53 (accessed 6 January 2014).

UNDP. The Human Rights-Based Approach to Development Cooperation: Towards a Common Understanding among the UN Agencies (2003), available at: www.undp.o rg/governance/docs/hr_guides_commonunderstanding.pdf (accessed 28 November 2014). 
USAID. "USAID Property Rights and Resource Governance Country Profile: Tanzania” available at: http://usaidlandtenure.net/sites/default/files/country-profiles/full-reports /usaid_land_tenure_tanzania_profile.pdf (accessed 8 October 2014).

VCS \& CCCB. "VCS+CCB Project Development Process," Version 3.0, 26 November 2012, available at: www.v-c-s.org/sites/v-c-s.org/files/vcs\%zoccb\%2oguidance\%zopro ject\%2odevelopment\%2oprocess, \%20v3.0.pdf (accessed 20 December 2013).

VCS Project Database. "Rimba Raya Biodiversity Reserve Project," available at: https:// vcsprojectdatabasez.apx.com/mymodule/interactive.asp?tab=projects\&a $=2 \& \mathrm{i}=674$ \&lat $=-2 \% 2 \mathrm{e} 78051067417254 \&$ lon $=112 \% 2 \mathrm{e} 170133504944 \& b \mathrm{~b}=1$ (accessed 7 January 2014).

VCS. "Agriculture and Forestry Projects" available at: www.v-c-s.org/develop-project lagriculture-forestry-projects (accessed 22 July 2014).

"Agriculture, Forestry and Other Land Use (AFOLU) Requirements," Version 3.4, 8 October 2013, available at: www.v-c-s.org/sites/v-c-s.org/files/afolu\%zorequire ments\%2 c\%20v3.4.pdf (accessed 20 December 2013).

"Jurisdictional and Nested REDD+ (JNR)", available at: www.v-c-s.org/jnr (accessed 15 December 2013).

"Our Mission," available at : http://v-c-s.org/who-we-are/mission-history (accessed 20 December 2013).

"VCS Program Guide," Version 3.5, 8 October 2013, available at: www.v-c-s.org/sites /v-c-s.org/files/vcs\%2oprogram\%2oguide\%2 c\%20v3.5.pdf (accessed 20 December 2013).

Wildlife Works, “About Us” available at: www.wildlifeworks.com/company/aboutus. php (accessed 15 December 2013).

World Bank - Grant Reporting and Monitoring (GRM) Report, "Indonesia - FCPF Readiness Preparation Grant" available at: http://forestcarbonpartnership.org/sit es/fcp/files/indonesia\%zogrm\%zofyzor3\%zorecipient\%zoexecuted.pdf (accessed 6 January 2013).

Operational Policy 4.12 - "Involuntary Resettlement" available at: http://web.world bank.org/wbsite/external/projects/extpolicies/extopmanual/o,,con tentmdk:20064610 menupk:4564185 pagepk:64709096 pipk:64709108 thesi tepk:502184,00.html (accessed 27 November 2014).

Operational Policy 4.36 - "Forests" available at: http://web.worldbank.org/wbsite/e xternal/projects/extpolicies/extopmanual/o,,contentmdk:20064668 me nupk:4564185 pagepk:64709096 pipk:64709108 thesitepk:502184,oo.html (accessed 27 November 2014).

World Bank. "Indonesia - FCPF Readiness Preparation Grant” available at: http://fo restcarbonpartnership.org/sites/fcp/files/indonesia\%zogrm\%zofyzo13\%zorecipi ent\%2oexecuted.pdf (accessed 6 January 2013).

Operational Policy 4.01 - "Environmental Assessment" available at: http://web.world bank.org/wbsite/external/projects/extpolicies/extopmanual/o,,con tentmdk:20064724 menupk:4564185 pagepk:64709096 pipk:64709108 thesi tepk:502184,00.html (accessed 27 November 2014).

Operational Policy 4.10 - "Indigenous Peoples" available at: http://web.worldbank. org/wbsite/external/projects/extpolicies/extopmanual/o,,contentmdk:20553653 menupk:4564185 pagepk:64709096 pipk:64709108 thesitepk:502184,00.html (accessed 27 November 2014). 
Operational Policy 4.11 - "Physical Cultural Resources" available at: http://web.wo rldbank.org/wbsite/external/projects/extpolicies/extopmanual/o,,con tentmdk:20970737 menupk:4564185 pagepk:64709096 pipk:64709108 thesi tepk:502184,00.html (accessed 27 November 2014).

WWF. "Natural forests protect against climate change" available at: http://wwf.panda .org/what_we_do/where_we_work/greatermekong/our_solutions/redd/ (accessed 15 December 2013).

\section{OTHER SOURCES}

Alden Wily, Liz \& Peter A. Dewees. "From Users to Custodians: Changing Relations between People and the State in Forest Management in Tanzania" (World Bank Policy Research Paper 2569, 2001).

Anderson, Patrick \& Torry Kuswardono. "Report to the Rainforest Foundation Norway on REDD in Indonesia” (September 2008) (on file with the author).

Asnawat Safitri, Myrna. Forest tenure in Indonesia: the socio-legal challenges of securing communities' rights (doctoral dissertation defended at the Faculty of Law of the University of Leiden, December 2010), available at: https:/openaccess.leidenu niv.nl/handle/1887/16242 (accessed 27 October 2014).

BAPPENAS. Indonesia National REDD+ Strategy (Draft 1 - September 2010) (on file with the author).

Indonesia National REDD+ Strategy (Draft 2-18 November 2010) (on file with the author).

Budi Indrarto, Giorgio et al. The Context of REDD+ in Indonesia. Drivers, agents and institutions (Bogor, Indonesia: CIFOR Working Paper 92, 2012).

Correspondence from Ralf Ernst. UNREDD Coordinator - Tanzania to Secretariat of the National REDD+ Task Force (on file with author).

Edwards, Bob \& Patrick F. Gillham. "Resource Mobilization Theory" Published online in The Wiley-Blackwell Encyclopaedia of Social and Political Movements (2013).

FCPF. Forest Carbon Partnership Facility (FCPF) Readiness Fund Common Approach to Environmental and Social Safeguards for Multiple Delivery Partners, 9 June 2011, rev. 10 August 2011.

Forrester Kibuga, Kate, Nuru Nguya, Hassan Chikira, Bettie Luwuge \& Nike Doggart. "Integrating the Principles of Free, Prior and Informed Consent in the Establishment of a REDD Project: A Case Study from Tanzania” (Making REDD work for communities and forest conservation in Tanzania, TFCG Technical Report 27, February 2011) (on file with the author).

FPP, PUASAKA \& HUMA. "National Update on REDD+ in Indonesia" (October 2011) (on file with the author).

HuMa et al., Proposal of Civil Society Networking for the First Draft of National REDD+ Strategy Jakarta, 25 October 2010 (on file with the author).

IFCA. "Reducing Emissions from Deforestation and Forest Degradation in Indonesia. REDD Methodology and Strategies. Summary for Policy Makers" (on file with the author).

Indonesia-Norway Partnership Joint Concept Note (3 December 2010) (on file with the author). 
Indonesian REDD+ Task Force. "REDD+ National Strategy" (June 2012) (on file with the author).

Institute of Resource Assessment. Preparing for the REDD Initiative in Tanzania: A Synthesised Consultative Report, November 2009 (on file with the author).

IUCN Tanzania Office. "Lessons Learned and Best Practice from REDD+ Pilot Projects" (12 September 2013) (on file with the author).

Letter of Intent between the Government of the Kingdom of Norway and the Government of the Republic of Indonesia on Cooperation on reducing greenhouse gas emissions from deforestation and forest degradation (26 May 2010) (on file with the author).

McCullogh, Lesley. "Ulu Masen REDD Demonstration Project. The Challenges of Tackling Market Policy and Governance Failures That Underlie Deforestation and Forest Degradation" (IGES, July 2010).

Ministry of Forestry. "Draft National Strategy on Enhancing and Maintaining Forest Carbon Stock through Sustainable Forest Management Activities: A Strategic Assessment" (April 2012) (on file with the author).

MJUMITA \& Tanzania Forest Conservation Group. "A one-step guide to making the National REDD strategy more pro-poor" Policy Brief, 2011 (on file with the author).

Mohammed, Essam Yassin. "Pro-poor benefit distribution in REDD + Who gets what and why does it matter?" IIED REDD Working Paper (2011), available at: http:// pubs.iied.org/pdfs/16508iied.pdf?.

National REDD+ Secretariat. "REDD+ Strategy Development and Implementation Process in Tanzania (1 October 2012 to 31 March 2013)" (on file with the author). "Tanzania's REDD Readiness Sites for REDD Pilot Projects" (on file with the author).

Nordeco \& Acacia. National REDD Policy Project in Tanzania, End-of-Project Review, Final Report, 25 February 2014 (on file with the author).

Readiness Preparation Proposal Template Document, Version 6, (23 November 2011), available at : www.unredd.net/index.php?option $=$ com_docman\&task=doc_down load\&gid=6869\&itemid=53 (accessed 30 December 2013), Annex 4.

REDD+ Secretariat. "Brief Report of a Study Tour to Brazil on REDD Experience" (on file with the author).

"Tanzania REDD Initiative Newsletter" Issue 2, January 2010 (on file with the author).

REDD+ SES. "Appendix 2. Draft Indicators for REDD+ Social \& Environmental Standards. Version July gth 2009 with new indicators and comments proposed by working groups in Tanzania on Sept gth 2009" in REDD+ SES, "REDD+ Social and Environmental Standards Consultation Meetings, 9th-11th Sept 2009, Tanzania" (9 October 2009) (on file with the author).

"REDD+ Social and Environmental Standards Consultation Meetings, 9th-11th Sept 2009, Tanzania" (9 October 2009) (on file with the author).

Royal Norwegian Embassy in Dar es Salaam. "Letter of Intent between the United Republic of Tanzania and the Kingdom of Norway on a Climate Change Partnership with focus on REDD" (2008) (on file with the author).

SATGAS REDD+. "Prinsip Kriteria dan Indikator Safeguards REDD+ Indonesia PRISAI" (version 3.1) (May 2013) (on file with the author). 
Steni, Bernadinus \& Iwan Wibisono. "Principles, Criteria and Indicator for REDD+ Safeguards Indonesia - PRISAI" (Bangkok, 6 March 2013) (on file with the author).

Steni, Bernadinus. "Ha Masyarakay Atas Tanah dan Sumber Daya Alam Dalam Strategi REDD+" (HuMa, 2013) (on file with the author).

Tanzania Forest Conservation Group. "Feedback on the Tanzania National REDD Strategy, prepared by the REDD Pilot Projects" 2011 (on file with the author).

Tauli-Corpuz, Victoria \& Aqqaluk Lynge. "Impact of climate change mitigation measures on indigenous peoples and on their territories and lands" E/C.19/2008 /10 (19 March 2008).

Tauli-Corpuz, Victoria \& Lars-Ander Baer. "The Copenhagen Results of the UNFCCC: Implications for Indigenous Peoples' Local Adaptation and Mitigation Measures" E/C.19/2010/18 (2 March 2010).

TFCG et al. "Recommendations from Civil Society Organisations for Tanzania's and Draft National REDD+ Strategy and Draft Action Plan" (on file with the author).

TFCG. "TZ-REDD Newsletter" Issue 9, January 2013 (on file with the author).

UN-REDD Programme. "National Programme Final Report - Indonesia” (18 January 2013) (on file with the author).

"National Programmes Final Report - Tanzania" (October 2013) (on file with the author).

"The Role of UN-REDD in the Development of REDD+ in Indonesia" (2012) (on file with the author).

Veierland, Kristine, Inclusive REDD+ in Indonesia. A Study of the Participation of Indigenous People and Local Communities in the Making of the National REDD+ Strategy in Indonesia (Master's Thesis, Department of Political Science, University of Oslo, October 2011).

Wajyudi, Leo \& Sopril Amir. "REDD+ National Strategy, Way to Indigenous Peoples' Rights and Existence" (7 August 2012). News item on website of the Indonesian REDD+ Task Force (on file with the author).

World Growth, Chapter 5: "Case Study: Failure of Protected Areas" in "REDD Conservation: Avoiding The New Road To Serfdom: A World Growth Report" (December 2010), available at: http://worldgrowth.org/site/wp-content/uploads /2012/06/wg_redd_conservation_report_12_10.pdf (accessed 11 June 2016).

WWF, "Fact Sheet: WWF Forest and Climate Programme, REDD+ Inspiring Practices: Building REDD = Readiness through participatory land use mapping and planning in Indonesia" (2014), available at: http://dzouvy59podg6 k.cloud front.net/downloads/final_ip_indo_land_map_english__web.pdf. 


\section{Index}

accounting, 43, 76, 151, 152

Acre, 80

actors

civil society, 47, 50, 105, 111, 114, 146

private, $12,14,15,31,35,38,39,46,58,173$, 191, 209

advocacy efforts, 55, 105, 111, 115, 179

affected communities, 53, 77, 78

aid

bilateral agencies, 64, 92, 93, 153, 175

development, 41, 49, 173

authorities, 5, 9, 40, 46, 52, 96, 103, 119, 121, 122,173

Bali Action Plan, 35, 36

benefits

multiple, 9, 5०, 68, 80, 137 social, $76,86,157,174,198$

bilateral agreement, 42, 94, 125, 160, 163

bilateral initiatives, 41, 42, 175

biodiversity, 9, 32, 38, 42, 43, 49, 51, 53, 63, 74, $76,79,106,111,117,138,141,154,155,157$, $161,197,220$

Brazil, 6, 8, 41, 43, 45, 47, 80, 83, 129, 151, 153, 201, 231

Cancun Agreements, 36, 58, 60, 61, 74, $84,85,105,107,111,134,138,140,147$, 195,196

capacity building, 2, 19, 36, 39, 42, 44, 51, 56, 63, carbon $93,119,128,140,156,161,184,196$

market, 9, 34, 38, 58, 152, 155, 161, 173, 198 sequestration, $1,3,8,10,12,37,86,100,159$, $173,174,194,201,210$

stocks, 1, 9, 35, 37, 127, 154, 160, 196, 198 carbon emissions

addressing, tackle, 34

avoiding, 37,38

forest-related, 37

reduction of, 1, 2, 34, 38, 45, 46, 87, 100, 104, $107,129,130,137,144,151,152,153,156,157$, 16o, 167, 170, 181, 184, 186, 196, 198, 208, 209

sources of, 34

tonnes of, 118

Carbon Fund, 39, 63, 64, 65, 133

Central Kalimantan, 43, 46, 80, 94, 106, 153, 154,157

charcoal, 27, 117, 118

civil society, 27, 50, 52, 55, 57, 64, 70, 94, 98, 99, $105,106,110,111,132,134,135,136,139,145$, $149,164,172$

climate

adaptation, 47, 57, 76, 127, 159

change, 2, 7, 9, 29, 31, 35, 39, 42, 45, 46, 55, $57,58,60,74,78,95,126,127,159,193,200$, 201, 209, 210

finance, 1,6

mitigation, 1, 9, 34, 35, 42, 47, 55, 57, 67, 76, $80,87,95,126,127,152,159,161,193$

co-benefits, 8, 35, 38, 49, 141, 152, 174

collaboration, 41, 53, 69, 73, 91, 96, 111, 127, 153, $162,163,166,167,183,185$

commitments, 70, 71, 73, 92, 114, 135, 156, 187, 190, 193

Conference of the Parties. See COP

conflicts, 8, 89, 90, 91, 98, 100, 101, 107, 110, 120, $121,168,181$

COP, $34,35,36,38,40,44,53,54,55,57,58,59$, $60,61,69,105,107$

corporate social responsibility, 49, 173, 190 
decentralization, 88, 120, 193

deforestation, 1, 2, 6, 8, 12, 26, 32, 34, 35, 37, 44, $45,54,60,67,87,89,93,99,104,118,129$, $137,138,144,151,154,155,157,159,167,170$, $174,179,181,184,186,187,197,201,208$

developing countries, 1, 2, 3, 7, 8, 10, 12, 13, 16, $28,29,30,32,34,35,36,3^{8}, 40,41,42,44$, $45,46,47,48,50,51,53,54,58,61,62,63$, $64,65,67,68,69,74,82,84,92,112,128$, $151,159,171,175,178,189,193,197,200,201$, 202, 208, 209, 210

development of legal norms, 15, 17 discrimination, 5, 6, 12, 77, 122, 124, 200 disputes, 27, 44, 82, 90, 101, 102, 108, 121, 142,187

Durban Platform, 58, 61

economic development, 64, 67 ecosystem services, 108, 117, 141, 154 ecosystems, 1, 35, 154, 155

energy, 42, 117, 118, 137, 170, 181, 186 environmental objectives, 38, 76

equity, 9, 10, 47, 52, 84, 210

FAO, 40, 68, 70, 87, 117, 118, 143

FCPF Charter, 39, 41, 49, 63, 65, 85, 96 Free, Prior and Informed Consent. See FPIC Food and Agriculture Organization. See FAO forest

conservation, 1, 29, 35, 36, 42, 47, 56, 83, 86, $91,102,118,120,125,129,132,134,137,138$, $141,153,154,157,160,161,162,166,167,169$, $173,183,185,190,193,197,211$

degradation, $1,12,35,37,44,54,60,87,89$, $93,99,118,129,138,154,155,157,159$, 167,201

governance of, 2, 3, 9, 10, 11, 12, 27, 29, 30, 32, $35,45,47,60,87,88,89,95,102,105,114$, $115,118,119,126,129,133,135,142,144,145$, $149,165,166,169,170,171,172,186,187$, $193,194,208$

management of, 103

sustainable management, 1, 12, 35, 88, 100, 102, 121, 129, 149, 197

Forest Act, 120, 121, 122, 138, 143, 144, 162, 163, $164,170,180,181,186$

forest dwellers, 3, 52, 65, 73, 85, 96

Forest Stewardship Council, 107

forest-dependent

communities, 2, 3, 5, 7, 8, 9, 10, 11, 12, 30, 56, $72,73,79,85,95,96,99,111,114,117,119$,
$130,134,137,138,139,142,143,144,146,147$, $148,149,164,165,174,179,181,182,183,185$, 186, 187, 189, 190, 191, 192, 195, 196, 202, 211 Indigenous Peoples, 65, 85

populations, 3

FPIC, 5, 9, 11, 13, 72, 84, 86, 96, 101, 102, 103, $106,108,110,111,137,143,161,163,164,166$, 180, 189, 190, 193, 196

human rights

law, 4, 6, 11, 12, 96, 106, 143

neglect of, 54,60

norms, 56, 83, 84, 197, 199, 200, 208, 209

protection of, $7,30,56,84,103,194,196$, 200, 210

recognition of, 86, 197

violations, 11, 124, 171

Indigenous Peoples

capacity of, 101, 172

distinctive status of, 113, 167

substantive rights of, 13, 66, 71, 95, 110, 113, $116,156,190$

International Emission Trading

Association, 152

involuntary resettlement, 66

jurisdictional REDD+

activities, 9, 29, 32, 33, 36, 51, 52, 58, 62, 63, $64,65,80,81,92,94,103,109,114,125,138$, $144,145,148,149,175,177,178,180,187$, 189, 190, 197, 199

policies, 110, 114, 115, 148, 149, 150, 187, 205 policy-making process, $114,116,183$

readiness, $8,26,32,44,45,48,50,51,52,67$, $68,69,72,73,74,80,82,92,94,97,105$, $109,110,111,112,113,115,126,127,128,129$, $137,139,144,146,148,149,150,154,164$, $175,178,182,187,190,196,197,200,201$

knowledge-sharing, 2, 36

Kyoto Protocol, 34, 58, 59

land

grabbing, 3

management, 74, 90, 119

land-based climate mitigation, 75, 76, 153

legal framework for REDD+, 54

legal recognition, 104, 158

logging, 27, 87, 115, 118, 122, 156, 157, 170, 186, 208 
marginalized groups, 71, 85, 141, 143, 180, 181, 204

mining, 9, 26, 87, 90, 102, 115, 118, 156, 170, 186, 208

multilateral development banks, 2, 36

multilateral environmental agreements, 57

multi-stakeholder consultations, 98, 110, 112, 149,178

National Climate Change Steering

Committee, 136, 140

national policies, 175

national REDD+ strategies, 45, 105, 206

negotiations, 34, 35, 36, 40, 54, 59, 193, 206

non-carbon benefits, 61,62

obligations

binding, 57

international, 6o, 65, 71, 73

operational policies, $64,65,66,84$

ownership, 98, 127, 162

palm oil plantations, 166, 170, 186

Paris Agreement, 36, 210

participation

effective, 30, 50, 52, 60, 61, 65, 66, 71, 77, 82, $84,85,107,110,132,133,142,157,178$, 180, 193

public, 4, 103

stakeholder, 93, 108

performance-based payments, 39, 63, 68, 93

policy-makers, 2, 154, 175, 191, 208, 209

population growth, 87,118

poverty, $1,12,35,38,61,67,71,74,78,87,118$, $126,133,137,149,167$

project developers, $75,76,78,86,160,165,166$, $167,168,170,171,174,176,183,185,186,190$

project-based REDD+ activities, 4, 6, 26, 29, 32, $33,3^{8}, 42,43,45,48,51,52,58,75,76,92$, $151,153,154,155,159,164,170,171,174,176$, $177,186,188,190,194,195,200,208$

property

Indigenous conceptions of, 6, 12

rights, $6,73,123,202,203$

protected areas, 119

recommendations, 65, 99, 114, 132, 134, 136

REDD+

finance mechanism, 145, 196

governance, 68

initiatives, $37,85,141,142,176,180,181,208$ pilot projects, 51, 127, 132, 134, 136, 145, 146, $163,164,165,176,186$

SES, 32, 43, 49, 51, 52, 54, 57, 79, 80, 81, 82, $83,84,85,86,106,138,139,140,141,142$, $143,146,147,178,190,195,201$

Social and Environmental Standards.

See SES

REDD+ readiness

activities, 40, 43, 49, 51, 93, 126, 127, 132,

133,197

efforts, 8, 40, 69, 79, 111, 113, 126, 127, 128, 178

REDD+ safeguards, 70, 80, 106, 109, 112,

140,142

reference emission level, 50, 196

regional human rights bodies, $5,8_{3}$

regulations, 40, 45, 46, 89, 92, 96, 154

resilience, norms, 144, 147, 176, 179, 187

resource rights, $4,12,13,27,52,78,97,102,104$, 106, 110, 142, 144, 159, 165, 168, 169, 171, 172, 179, 181, 183, 185, 186, 188, 193, 208, 211

review, 4, 7, 8, 9, 50, 83, 109, 114, 140, 160, 162 , 163,172

right to self-determination, 5

rights

community, 3, 4, 10, 13, 26, 27, 28, 30, 32, 57, 6o, 62, 77, 83, 85, 86, 99, 115, 129, 132, 134, 169, 172, 174, 178, 185, 189, 190, 193, 194, 196,210

construction of, 33, 116, 177, 178, 183, 186, 191, 199, 200, 202

conveyance of, 112, 178, 201

formal, 99, 162, 187

Indigenous, 29, 56, 91, 101, 109, 113, 134, 144, 150, 164, 179, 182, 187, 190, 193

Indigenous Peoples', 2, 3, 4, 7, 13, 16, 25, 28, $29,30,31,32,33,47,51,53,54,55,56,57$, $59,60,62,66,71,72,73,78,79,81,82,83$, $89,95,96,99,100,105,106,107,108,109$, $110,111,112,113,114,115,116,124,129,130$, $133,134,139,142,143,144,146,147,148,149$, $152,156,157,158,159,163,164,167,170,171$, $177,178,179,180,181,182,184,185,186$, 187, 189, 190, 191, 192, 193, 194, 196, 197, 198, 199, 201, 202, 203, 204, 205, 206, 207, 208, 210, 211

recognition of, 86, 111, 115, 194

rights-based approach, 64, 69, 73, 86, 19o, 203, 204

rights-holders, 81,85

rural communities, 1, 27, 35, 87, 88, 91, 95, 118, $120,121,125,130,133,200$ 
safeguard information system, 61, 74

sanctions, 121

sites of law, 4, 13, 14, 16, 17, 22, 23, 25, 29, 31, 32, $39,42,43,47,49,50,52,53,54,56,57,58$, $83,84,86,170,174,176,187,189,190,191$, 193, 195, 200, 201, 202, 204, 205, 206, 207, 208

social development, 76, 91, 148, 167

social safeguards, $38,47,56,60,61,84,103$, 106,147

socio-legal

scholars, 13,172

study, 3, 30, 31

sovereignty, 61, 84, 90

sustainable development, 7, 42, 152, 172

stakeholder engagement, 44, 50, 52, 68, 73, 74

statutory rights, $78,119,121$

Strategic Environmental and Social Assessment, 108

strategies, 22, 32, 37, 40, 78, 117, 138, 154, 155, 181, 186,191

Subsidiary Body for Scientific and Technological Advice (SBSTA), 58 sustainability of REDD+ projects, 166,184 sustainable forest management, 68, 101, 174 synergies, 3, 8, 33, 189, 208

technical advisory panel, 50, 96, 97, 131, 132 technical assistance, 2, 36, 40, 41, 42, 44, 51, 63, 69, 92, 93, 128, 197

technical experts, 58, 82

trade-off, 30, 47, 196

traditional

knowledge, 107, 108, 137, 180

lands, 2, 6, 11, 12, 88, 90, 122, 125, 150

rights, $3,6,88,98,123,164$

transnational legal process, $3,4,13,14,15,16,22$, $23,24,25,28,29,30,31,32,33,38,39,47$, $49,50,51,53,58,159,176,186,187,189$, 190, 191, 193, 198, 200, 201, 202, 203, 204, 205, 206, 207, 208, 209

transparency, 62 tropical forest, 73

trust fund, 39, 63, 65, 145

UN

Declaration of the Rights of Indigenous Peoples, 62, 107

Development Programme. See UNDP

Environment Programme. See UNEP

Framework Conference for Climate Change. See UNFCCC

General Assembly, 60

UNDP, 40, 60, 64, 66, 68, 69, 70, 98

UNEP, 40, 46, 68, 70

UNFCCC, 1, 2, 7, 32, 34, 35, 36, 37, 38, 39, 40, $44,46,48,49,51,53,54,55,56,57,58,59$, $60,61,62,69,71,80,83,84,85,92,105$, $107,113,126,133,138,139,146,147,176,189$, 190, 193, 195, 199, 201, 205, 206, 211

UN-REDD Programme, 32, 39, 40, 45, 48, 50, 51, 52, 54, 55, 57, 68, 69, 70, 71, 72, 73, 74, $83,84,85,86,93,97,98,99,101,106,112$, $127,128,134,135,138,144,148,195,201,209$

validation, $43,76,152,153,155,160,173,198$

VCS, 40, 43, 76, 152, 153, 155, 160, 165, 173, 174, $183,197,209$

Verified Carbon Standard. See VCS

Village Land Act, 120, 121, 125, 143, 145, 163

Warsaw Framework for REDD+, 59

Wildlife Conservation Society, 74

women, 77, 79, 82, 91, 103, 107, 141, 180, 200, 210

workshops, 72, 79, 94, 107, 134, 136, 139, 140, 149,196

World Bank, 25, 32, 39, 40, 54, 57, 63, 64, 65, $66,67,83,84,85,86,93,96,97,107,111$, $117,120,128,132,133,138,148,190,195$, 201, 209

FCPF, 86, 128

Forest Carbon Partnership Facility. See FCPF 